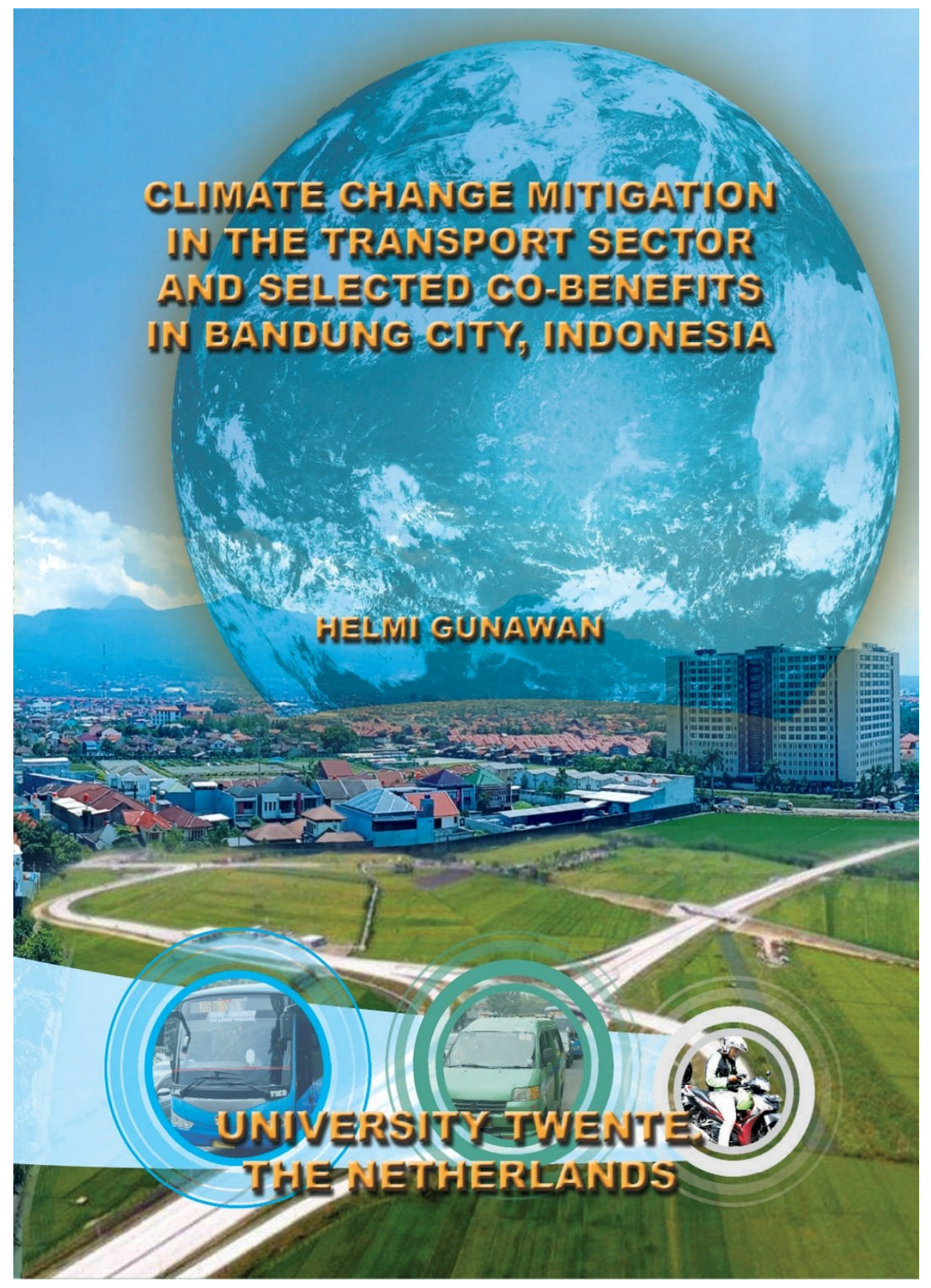




\title{
CLIMATE CHANGE MITIGATION IN THE TRANSPORT SECTOR AND SELECTED CO-BENEFITS IN BANDUNG CITY, INDONESIA
}

\author{
DISSERTATION
}

to obtain

the degree of doctor at the University of Twente,

on the authority of the rector magnificus,

Prof.dr. T.T.M. Palstra

on account of the decision of the graduation committee,

to be publicly defended

on Thursday $5^{\text {th }}$ September 2019 at 16.45

by

Helmi Gunawan

born on $18^{\text {th }}$ March 1974 ,

in Bandung, Indonesia 
This dissertation has been approved by

Supervisor: Prof. dr. J.T.A. Bressers

Co-Supervisor: Dr. T. Hoppe

Co-Supervisor: Dr. N. Mohlakoana 


\section{Graduation Committee:}

\begin{tabular}{|c|c|c|}
\hline Chairman/Secretary & Prof. dr. T.A.J. Toonen & University of Twente/BMS \\
\hline PhD Supervisor & Prof. dr. J.T.A. Bressers & University of Twente/BMS - CSTM \\
\hline PhD Co-Supervisor & Dr. T. Hoppe & TU Delft / TPM \\
\hline PhD Co-Supervisor & Dr. N. Mohlakoana & University of Twente/BMS - CSTM \\
\hline Internal member & Prof. mr. dr. M.A. Heldeweg LLM & University of Twente/BMS - CSTM \\
\hline Internal member & Prof. dr. Ir. M.F.A.M van Maarseveen & University of Twente/ITC \\
\hline External member & Prof. J. Iskandar, M.Sc, Ph.D & University of Padjadjaran/PSDIL \\
\hline External member & Ir. R. Driejana, MSCE, Ph.D & Bandung Institute of Technology/FTSL \\
\hline
\end{tabular}

The work described in this thesis was performed at the Department of Governance and Technology for Sustainability (CSTM), Faculty of Behavioural, Management and Social Sciences, University of Twente, PO Box 217, 7500 AE, Enschede, the Netherlands 
Colophon

C2019 Helmi Gunawan, University of Twente, Faculty BMS/CSTM

No part of this publication may be reproduced, stored in a retrieval system, or transmitted, in any form or by any means, electronic, mechanical, photocopying, recording or otherwise, without prior written permission of the author.

Book Cover design: Helmi Gunawan

Printed by:

ISBN/EAN: 978-94-028-1654-9

DOI $\quad: 10.3990 / 1.9789402816549$

\section{UNIVERSITY OF TWENTE}

Faculty of Behavioural, Management and Social sciences (BMS)

Department of Governance and Technology for Sustainability (CSTM)

Enschede, the Netherlands

Email (for correspondence): h.gunawan@utwente.nl; helmigun1@gmail.com 



\section{Table of Contents}

Table of Contents $\quad v$

List of Tables and Figures $\quad$ viii

List of Abbreviations and Acronyms $\quad x$

Acknowledgements $\quad x i$

Chapter 1: Introduction to Climate Change Mitigation in the Transport Sector 1

$\begin{array}{lll}1.1 & \text { Background } & 1\end{array}$

1.2 Problem Definition 5

1.3 Research Question and Study Objective 9

1.4 Research Design and Methodology 10

$\begin{array}{ll}\text { 1.4.1 Introduction } & 10\end{array}$

1.4.2 The Phase in Conducting a Case Study on the Implementation of 11 Relevant Policy Instrument

1.4.3 Survey on Behavioural Change in the Use of Transport Modes 12

1.5 Overview of the Following Chapters 13

Chapter 2: Theoretical Frameworks $\quad 15$

$\begin{array}{ll}2.1 & \text { Introduction } \\ 2.2 & 15\end{array}$

$\begin{array}{lll}2.2 & \text { Policy Implementation } & 15\end{array}$

2.3 Contextual interaction Theory (CIT) 17

$\begin{array}{ll}\text { 2.3.1 The Basics } & 18\end{array}$

$\begin{array}{ll}\text { 2.3.2 Actor Characteristics as Core Characteristics } & 18\end{array}$

$\begin{array}{ll}2.3 .3 & \text { The External Contexts } \\ & 19\end{array}$

2.3.3.1 The Wider Context $\quad 20$

2.3.3.2 The Structural Context 20

2.3.3.2.1 Governance Assessment Tool as Part of CIT 22

2.3.3.3 The Specific Case Context $\quad 25$

2.4 Environmental Psychology and Behavioural Theory 25

2.5 Conclusion 31

Chapter 3: Incorporating Air Quality Improvement at a Local Level into Climate 33

Policy in the Transport Sector: A Case Study in Bandung City, Indonesia

3.1 Introduction 33

3.2 Low-Carbon Transport Governance and Co-Benefits 35

3.2.1 The Concept of Co-Benefits $\quad 36$

$\begin{array}{lll}3.3 & \text { Contextual Interaction Theory Framework } & 37\end{array}$

$\begin{array}{lll}3.4 & \text { Methods } & 39\end{array}$

3.4.1 Data Collection: Interview and Secondary Data 39

3.4.2 Data Analysis and Results $\quad 39$

3.4.2.1 General Introduction to the Bandung Case Study 39 
3.4.2.4 Results of the Actor Interaction Analysis $\quad 51$

3.5 Discussion 53

3.6 Conclusions 54

Chapter 4: Governance of Climate Change Mitigation in Bandung City 57

$\begin{array}{ll}4.1 & \text { Introduction } \\ 4.2 & 57\end{array}$

4.2 Levels and Scales $\quad 58$

$\begin{array}{lll}4.3 & \text { Actors and Networks } & 67\end{array}$

4.4 Problem Definitions and Goals $\quad 70$

$\begin{array}{lll}4.5 & \text { Strategies and Instruments } & 75\end{array}$

4.6 Responsibilities and Resources $\quad 80$

4.7 Summary of Findings $\quad 81$

$\begin{array}{lll}4.8 & \text { Conclusions } & 87\end{array}$

Chapter 5: Paratransit as a Public Transport $\quad 89$

5.1 Introduction $\quad 89$

5.2 Governance of Paratransit $\quad 90$

$\begin{array}{ll}\text { 5.2.1 Levels and Scales } & 91\end{array}$

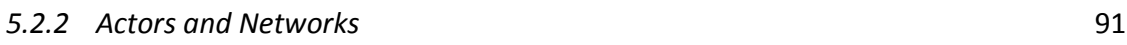

5.2.3 Problems Perspective $\quad 92$

5.2.4 Strategies and Instruments $\quad 94$

5.2.5 Responsibilities and Resources $\quad 95$

$\begin{array}{lll}5.3 & \text { The Resume of Paratransit Governance } & 97\end{array}$

$\begin{array}{ll}5.4 \text { Contextual interaction Theory Analysis of Paratransit } & 97\end{array}$

$\begin{array}{lr}\text { 5.4.1 Motivation } & 98\end{array}$

$\begin{array}{lr}\text { 5.4.2 Cognitions } & 101\end{array}$

$\begin{array}{ll}\text { 5.4.3 Capacity and Power } & 104\end{array}$

$\begin{array}{lll}5.5 & \text { Discussion and Conclusions } & 107\end{array}$

5.6 Improving Public Transport as Part of Climate Co-Benefits 108

Chapter 6: Evaluation of Co-Benefits Approach Criteria 111

$\begin{array}{ll}6.1 \text { Introduction } & 111\end{array}$

6.2 Low-Carbon Transport Governance as part of LEDS 111

6.3 Selected Criteria Indicators of Co-Benefits 113

6.4 Evaluation of the Climate Co-Benefits Programme Implementation 120

6.5 The Assessment of Policy Instruments 121

6.5.1 Mitigation Potential 122

$\begin{array}{ll}\text { 6.5.2 Sustainability } & 124\end{array}$

$\begin{array}{ll}\text { 6.5.3 Development Goals } & 125\end{array}$

$\begin{array}{ll}\text { 6.5.4 Political, Social, and Technical Feasibility } & 125\end{array}$

$\begin{array}{lll}6.6 \text { Conclusions } & 126\end{array}$ 
Chapter 7: Vehicle Users Attitudes and Behaviour Concerning Climate Change

Policies and Travel Choice Mode

$\begin{array}{ll}7.1 \text { Introduction } & 127\end{array}$

$\begin{array}{ll}7.2 \text { Objectives of this Study } & 127\end{array}$

$\begin{array}{ll}7.3 \text { Methodology } & 128\end{array}$

$\begin{array}{llr}7.4 \text { Results } & 129\end{array}$

$\begin{array}{lll}\text { 7.4.1 Socio-Demographic Variables } & 130\end{array}$

$\begin{array}{lll}\text { 7.4.2 } & \text { Travel Priorities } & 136\end{array}$

7.4.3 User Preference on the Policy Instruments and their Perceived 139 regarding $G H G$

$\begin{array}{ll}7.5 \text { Discussion } & 146\end{array}$

$\begin{array}{ll}7.6 \text { Conclusions } & 150\end{array}$

Chapter 8: Conclusions and Recommendations 153

8.1 Conclusion from the Empirical Chapters 153

$\begin{array}{ll}\text { 8.2 Empirical Contributions and Policy Implementations } & 159\end{array}$

$\begin{array}{ll}\text { 8.3 Reflections on the Theoretical Framework Used } & 160\end{array}$

8.4 Limitations and Suggestion for Future Research 160

$\begin{array}{ll}8.5 \text { Closing } & 161\end{array}$

Bibliography 163

$\begin{array}{ll}\text { Annexure i } & 177\end{array}$

$\begin{array}{ll}\text { Annexure ii } & 183\end{array}$

$\begin{array}{ll}\text { Summary } & 187\end{array}$

$\begin{array}{lr}\text { Summary (in Bahasa) } & 189\end{array}$

Samenvatting (in Dutch) 193

$\begin{array}{ll}\text { About the Author } & 197\end{array}$ 


\section{List of Tables and Figures}

\section{Tables}

Table 1.1 The supplement using of case study research and survey approaches 12

Table 2.1 Ambiguity-Conflict Matrix: Policy Implementation Processes 16

Table 2.2 Main evaluative questions of Governance Assessment Tool 23

Table 2.3 Motivations and barriers to public transport use 26

Table 2.4 Principles for intervening to change environmentally destructive behaviour 28

Table 3.1 The number of public and private vehicles based on type in Bandung City $\quad 40$

Table 3.2 Impact of transportation in Bandung City 41

Table 3.3 Particular policies that could contribute to lowering GHG emissions 46

Table 3.4 Stakeholders of climate change mitigation and air quality improvement in 50 the transportation sector (Bandung City)

Table 4.1 Overlay mitigation actions based on legal basis of multi-level governance in $\quad 59$

Table 4.2 Key institution elaborated in Indonesia's climate change response 62 (mitigation)

Table 4.3 Bilateral relationship regarding climate finance in Indonesia 64

$\begin{array}{lll}\text { Table 4.4 Assessment results for levels and scales } & 67\end{array}$

Table 4.5 Assessment results for actors and networks $\quad 69$

$\begin{array}{lll}\text { Table 4.6 Assessment results for problem perspectives and goal ambitions } & 74\end{array}$

$\begin{array}{lll}\text { Table } 4.7 & \text { Cases of NAMAs and Registry } & 76\end{array}$

$\begin{array}{lll}\text { Table } 4.8 & \text { Assessment results for strategies and instruments } & 79\end{array}$

Table 4.9 Assessment results for responsibilities and resources 81

Table 4.10 Qualities of governance from policies instruments 83

Table 6.1 Comparison of Business as Usual and Sustainable Transportation 112

$\begin{array}{lll}\text { Table 6.2 Sustainable urban transport in three domains } & 113\end{array}$

Table 6.3 Indicator sources of co-benefits transport sector activities 117

$\begin{array}{lll}\text { Table 6.4 Comparison of the programs } & 120\end{array}$

Table 6.5 Assessment of policy instruments that aim to contribute to mitigation 122 climate change and selected co-benefits

$\begin{array}{llll}\text { Table 7.1 Descriptive statistic of respondent's socio-economic characteristic } & 130\end{array}$ (exogenous variables)

Table 7.2 Gender distribution and possession of driver license in private vehicle ownerships

Table 7.3 Frequency of using travel mode

Table 7.4 Age and frequency of using car cross tabulation 132

$\begin{array}{lll}\text { Table 7.5 Marital status and frequency of using car cross-tabulation } & 134\end{array}$

Table 7.6 Spearman correlation of socio-demographic and frequent travel mode $\quad 135$ 
Table 7.7 The occupation and frequency of using motorcycle

Table 7.8 The statement concerning attitude and intention of environmentally significant behaviour

Table 7.9 Correlation between the willingness to use of private vehicles compare to the public transport

Table 7.10 Correlation between the low carbon transport policies

\section{Figures}

$\begin{array}{lll}\text { Figure } 1.1 & \text { Flowchart of research planning stages and activities } & 10\end{array}$

Figure 1.2 Thesis outline 13

Figure 2.1 Dynamic interaction between the key actor-characteristics that drive social- $\quad 19$ interaction processes and in turn are reshaped by the process

Figure 2.2 Contextual Interaction Theory 20

Figure 2.3 The independent variables used for survey willingness to change 29

$\begin{array}{lll}\text { Figure } 3.1 & \text { Contextual Interaction Theory } & 38\end{array}$

Figure 3.2 Greater Bandung Metropolitan Area $2017 \quad 40$

Figure 3.3 GHG emissions by sector in Bandung City 42

Figure 3.4 Dynamic actor-characteristic's interaction of local-level actors 52 (implementers)

Figure 4.1 Source of funding on mitigation action at local level 63

Figure 5.1 Information of public transport in certain areas in Bandung City 98

Figure 5.2 Paratransit drivers waiting for passengers to get into vehicles (pic. above) 99 while the online motorcycle taxies wait for the nearest passengers (pic. below)

Figure 5.3 In the same lane, a school bus is free of charge and attracts student to ride 105 (left side), while a paratransit struggles to get a passenger (right side)

Figure 5.4 The Trans Metro Bandung that shares the same lanes with paratransit and 107 school bus at Jl. Soekarno-Hatta, Bandung (Cibiru-Cibeureum corridor)

$\begin{array}{lll}\text { Figure 6.1 Aim of integrated local and global problem } & 115\end{array}$

Figure 6.2 Framework of co-benefit approach in the transport sector 116

$\begin{array}{lll}\text { Figure 7.1 The respondent reasons in using public vehicles } & 137\end{array}$

$\begin{array}{lll}\text { Figure 7.2 The respondent reasons in using private vehicles } & 138\end{array}$

Figure 7.3 Source of congestion based on respondents 139

Figure 7.4 The valid frequency of respondent's perception of global and local 140 problems

Figure 7.5 The valid frequency of attitude towards public transport and private 141 vehicles

Figure 7.6 The valid frequency of attitude towards transport policy measures 143

Figure 7.7 The valid frequency of attitude towards public transport as a solution to 145 climate change mitigation 


\section{List of Abbreviations and Acronyms}

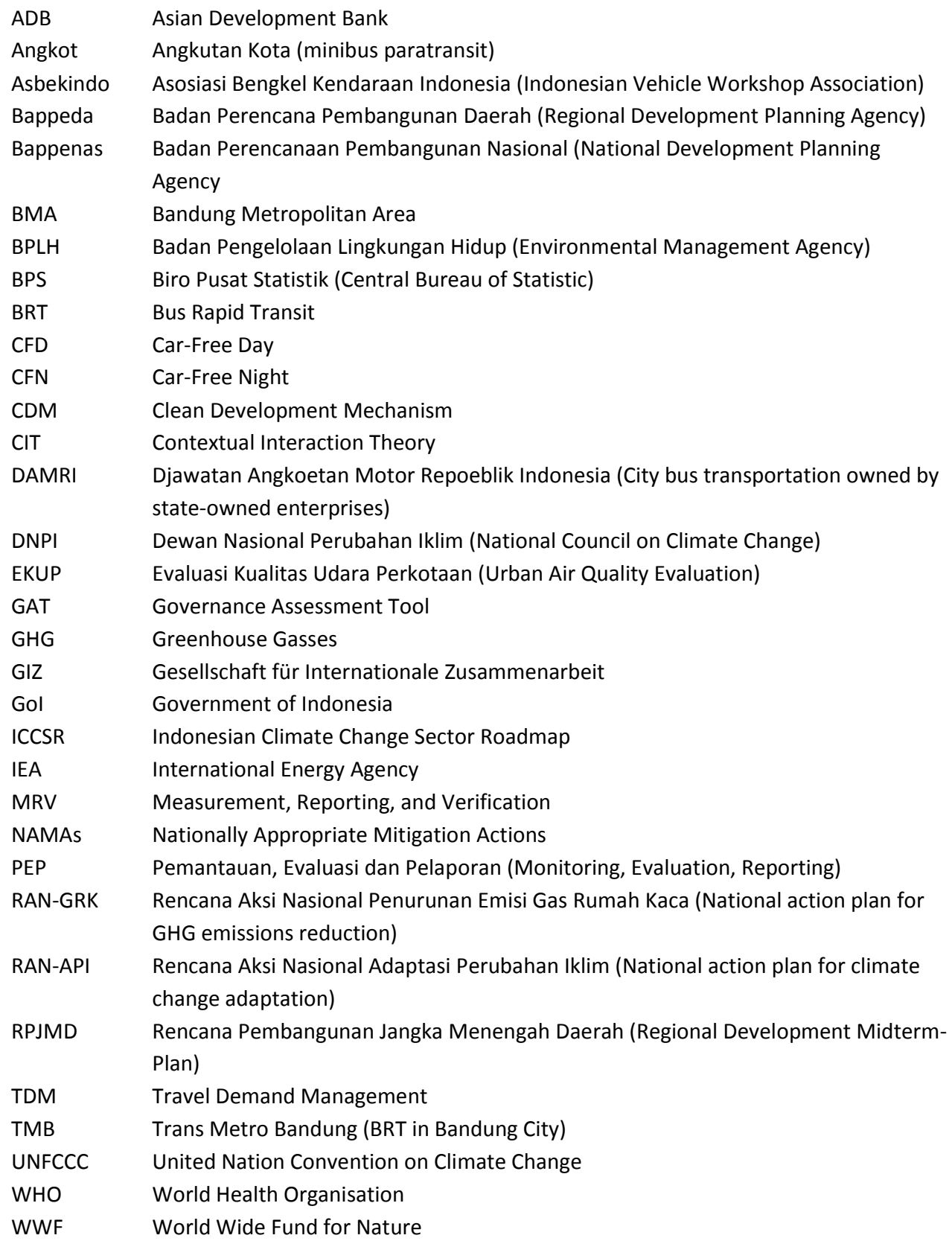




\section{ACKNOWLEDGEMENT}

At the end of this thesis, I take this opportunity to extend my sincere gratitude and appreciation to all those who made this thesis possible. First, I give thanks to God, the Almighty for protecting me and giving me the strength to finish this thesis. Although it is just my name on the cover, many people have contributed to the research in their own particular way and for that, I want to give them special thanks.

I would like to give gratitude to the UTwente supervisors, Prof. Hans Bressers who encouraged and directed me. It is with your supervision that this work came into existence. Thank you for trusting me in finishing this study and help me pursue my goals and help my family gets a very valuable experience. I am also deeply thankful to my daily supervisors, Thomas Hoppe and Nthabiseng Mohlakoana, who were prepared to sit and listen to my troubles and always made me feel as a special person.

I would like to extend my thanks to all my CSTM colleagues. Sheheen Abdulkareem, Houda EI Mustapha and Leila Niamir thank you for your warm welcome and make me as your "uncle". Cesar Casiano Flores who always help me if I have got stuck. Norma Contreras, Imke Lammers, Mansi Jain, Monica Ramos, Alaa Alzughayyar, M. Assaduzzaman, Ewert Aukes, Koen de Koenig, Beau Warbroek thank you for being lovely friends. Gül, Nthabi, Aldi thank you for sharing your experience. Not to mention my home country colleagues in CSTM who always support and help struggled together to experience various obstacles. Heksi Lestari (Sisi) let's go! only small step ahead, sis! Nicco Plamonia, Sisfahyuni, Kamia Handayani, Vina, Lina and Rahmi keep the spirit! Dwi Mandaris, Sunu, Irsyad, Deby Fajar, Akbar, Yosia and others which makes staying here more beautiful. Thanks for the friendship and memories.

This appreciation also goes to Barbera and Annemiek for giving administrative support during my Ph.D. in Twente. Barbera, thank you for helping me to find a place to stay and give my family the opportunity to live in Enschede. You continued to assist me in preparing all in finalizing my study, I really appreciate that.

I would like to express my appreciation to Unpad supervisors, Prof. Erri, Mr. Benito and Mr. Pam. Thank you, Mr. Sunardi and Mr. Chay Asdak for the support and help towards my postgraduate affairs. My acknowledgement also goes to all staffs of PSDIL for their assistance and co-operation. Sincere thanks to all my PSDIL friends, Gilang, Mr. Anton, Mr. Dadan, Mrs. Kamalia, Neti, Farha, Mr. Uus, and others for their kindness and moral support during my study. Big thanks to Om Tulus, Teh Ande, Alin, Hari Pradiko and Arief Sutadian that have spent precious time to discuss and give feedback. 
All the practitioners, policy-makers and researchers from Bandung City and West Java Province that contribute to my fieldwork, especially the associations, cooperatives, and drivers; thank you for openly sharing your views and opinions.

A special thanks to my family -- my mother (Mah Lin), my wife (Nadissa DS), my sons (Athhar Faris, Ahmad Naufal and Atreya Raifano), my sisters (Shanty, Ira, Gigi) and brothers (Heri) who encouraged me and prayed for me throughout the time of my research. My parents-in-law (Mah Neni - Pah Wawan), sisters-in-law (Icha, Yuli, Okta) and brothers-in-law (Akang), for being a supportive and encouraging family.

This thesis is heartily dedicated to my father (Alm. Burhaeni) who took the lead to heaven before the completion of this work. 


\section{Chapter 1: Introduction to Climate Change Mitigation in the Transport Sector}

\subsection{Background}

Global climate change, environmental degradation, poverty, a lack of water and food and population density pressures are all factors that magnify disasters that should be avoided, mitigated and thoroughly managed, particularly in developing countries (MoE, 2007; UNFCCC, 2007; Watson et al., 2001). Most climate models predict Greenhouse Gas $^{1}$ emissions (GHGs) to rise twofold from pre-industrial times and forecast average temperature increases of between $2^{\circ} \mathrm{C}$ and $5^{\circ} \mathrm{C}$ by the year 2030 and 2060 respectively (Stern, 2006). A WWF report in Indonesia (2007), which included results from a study by Hulme and Sheard (1999), showed there has been a marked increase by $0.3^{\circ} \mathrm{C}$ of the annual basis average temperature and a decrease in annual rainfall by 2-3 percent since 1900 (Case, Ardiansyah, \& Spector, 2007).

Southern parts of Indonesia has experienced a decline in annual rainfall, while an increase of rainfall has been recorded in the Northern regions (Lasco \& Boer, 2006). Evidence from Bandung City (the third largest urban city in Indonesia and the central research domain for this doctoral study) for temperature data collected (1960-2010) shows a consistent rising trend, whilst (BPLH, 2013) other various conditions exist elsewhere in Indonesia. Rapid population growth and human activity have exacerbated climate change via anthropogenic emission sources (alongside natural emissions of GHGs).

In general, energy consumption correlates with gross domestic product (GDP). To a large extent, this is due to activities in urban areas (Robert, 2007). The scale of impact and risks of climate change mean efforts are needed to reduce and manage climate change involving both mitigation and adaptation (Barker, 2007; Bulkeley et al., 2009). Mitigating climate change can be achieved by reducing GHGs and enhancing carbon sinks. Adaptation looks to measures to respond and deal with the impacts of climate change. Nevertheless, continued growth of GHG emissions - when the mitigation effort is not implemented - means the risk and impact of climate change will be more severe. The climate change mitigation scheme (IPCC) expects only a slight effect on climate conditions in the next decade. Successful mitigation efforts might be able to avoid major climate change from happening in the future (Dessler, 2012). This main work is mainly needed in urban areas, where GHG emissions equal $67 \%$ of total emissions generated. These come primarily from transportation, energy consumption (in general), construction activities and the use and manufacturing of buildings, and waste treatment (ADB, 2008).

There are four important issues pertinent to climate change in Indonesia: (1) the country is becoming highly vulnerable to global warming and the impacts of climate change; (2) the country's second largest GHG emissions comes from land use change or deforestation activities;

${ }^{1}$ Kyoto protocol the group of greenhouse gasses as Carbon dioxide $\left(\mathrm{CO}_{2}\right)$, Methane $\left(\mathrm{CH}_{4}\right)$, Nitrous Oxide $\left(\mathrm{N}_{2} \mathrm{O}\right)$, Hydro Fluorocarbon (HFCs), Per fluorocarbons (PFCs) and Sulphur Hexafluoride (SF6) (IPCC, 2001) 
(3) the country contributes to carbon emitters from energy consumption; and, (4) the country is still struggling with achieving adequate economic development to alleviate poverty, notably in coastal areas (Yusuf, 2010).

The use of fossil fuels for economic development has played an important role in Indonesia. Although the Republic of Indonesia (Rol) has ratified several international conventions related to climate change ${ }^{2}$, it has no formal obligation to reduce GHG emissions. Nonetheless, in 2009, Indonesia committed itself to voluntarily reducing greenhouse gas emissions by $26 \%$ by 2020 from the level of Business as Usual (BAU) by itself, and $41 \%$ when alongside international assistance mechanisms.

In 2010, the Government of Indonesia (Gol) launched the Indonesia Climate Change Sectoral Roadmap (ICCSR) 2010-2030. This set national objectives, sectoral targets ${ }^{3}$, and priority measures related to adaptation and mitigation of climate change for different economic sectors. ICCSR content has been integrated into development planning; namely the Medium-Term Development Plan (RPJM) for 2010-2014 and the Government Work Plan (RKP). The Presidential Decree No. 61 Year 2011 on National Action Plan for Mitigation Greenhouse Gasses (RAN-GRK) has reinforced it. The National Action Plan on Climate Change Adaptation (RAN-API) has strengthened efforts on mitigation (RAN-GRK) as formulated in a synthesis report (Bappenas, 2013).

The transport sector, in particular, faces difficulty in reducing $\mathrm{CO}_{2}$ emission given the many primary economic activities that rely on this sector. The transport sector contributes to $26 \%$ of global $\mathrm{CO}_{2}$ emissions. It is one of the few industrial sectors where emissions are still growing (Chapman, 2007). Nonetheless, targeting this sector for mitigation actions also has other negative effects, such as social and economic costs.

In climate change mitigation terminology, transport is a sector with a huge potential to be included in the Clean Development Mechanism projects ${ }^{4}$ (CDM) or in Nationally Appropriate Mitigation Actions ${ }^{5}$ (IGES, 2011). Although climate change is a global problem, mitigation efforts remain highly dependent on actions taken locally. For example, people can use or combining various options to improve air quality and, at the same time, lower GHG emissions in the urban

\footnotetext{
${ }^{2}$ Law no. 6 year 2004 about Climate Change and Law no. 17 year 2004 about Kyoto Protocol

${ }^{3}$ Agriculture; forestry and peat land; energy and transportation; industry; waste management; other supporting activities

${ }^{4} \mathrm{CDM}$ is one of the flexible mechanisms defined in the Kyoto Protocol (IPCC, 2007), which provide a project that generate certified emission reduction unit that can be traded in the international emissions trading scheme (Halsnaes \& Shukla, 2008)

${ }^{5}$ Nationally Appropriate Mitigation Actions (NAMAs) is a new instrument regarding international climate policy that aims to tackle issues of GHG in developing countries, which contribute to sustainable development. NAMAs has to require Measurement, Reporting and Verification (MRV) (UNFCCC, 2014)
} 
transport sector in specific areas of cities (Creutzig, Mühlhoff, \& Römer, 2012; Hamilton \& Akbar, 2010).

Another problem that requires attention in urban areas is air pollution associated with the steep increase of transport vehicles used. The number of vehicles in Bandung City has increased 10-15 percent annually. Compare this to increased road construction $\left(0.45 \%\right.$ per year $\left.{ }^{6}\right)$ and this reflects less supply of capacity, rather than reduced demand and has helped trigger congestion of vehicles in Bandung City (Bigazzi, 2011; Eldewisa \& Driejana, 2008).

This issue is exacerbated by the lack of green open space areas ( $\pm 8 \%$ of the total Bandung City area, compared to the plan prescriptions that mention 30\%) (BPLH, 2013). Empirical data shows that air temperature in Bandung City has risen about $2^{\circ} \mathrm{C}$ in the last 20 years (RPJMD Bandung City 2008-2013). The observation of Urban Heat Island (a high temperature between $30-35^{\circ} \mathrm{C}$ in Bandung City with a dense situation of buildings) has increased approximately 12,606 ha every year or 4.47\%, between 1994 and 2001 (Tursilowati, 2002).

The academic literature is giving more attention to these transport sector problems of GHG emissions, air pollution and local action. The 1987 Brundtland Commission report developed the concept of sustainable development and the role of stakeholders to collaborate to earmark its principles in urban cities context (Goldman \& Gorham, 2006). In particular, sustainable transport (or sustainable urban transportation) has received more attention (Goldman \& Gorham, 2006; Greene, D.L; Wagener, Greene, \& Wegener, 1997). In summary, the transport sector is seen as hampering the use of resource inputs, such as energy, human and ecological habitats, atmospheric carbon loading capacity, and individual available time. The concept, while multidimensional, encompasses three areas: (1) implementing technology, (2) pricing and financing, and (3) integrated transport and land use planning. Sustainable transportation is a societal, rather than a strictly technical, process that depends on upon planning, policy, economics and citizen involvement (Schiller, Brunn, Kenworthy, Bruun, \& Kenworthy, 2010).

Another approach that deals with problems at global and local level is the co-benefits ${ }^{7}$ approach (Creutzig et al., 2012; Jack \& Kinney, 2010; Lee \& Van De Meene, 2013; Nemet, Holloway, \&

\footnotetext{
${ }^{6}$ Based on growth of construction from 2002 - 2014 (analysis from BPS Bandung City data)

${ }^{7}$ The term co-benefits has different meanings, particularly regarding definitions and indicators. Puppim de Oliviera, et al. (2013) studied the implementation of climate co-benefits initiatives in urban Asia. They defined co-benefits as benefits to the local environment as a result of mitigation actions / adaptation in addressing global environmental change. Lee \& Meene (2013) examined the different types of co-benefits (climate co-benefits and environmental co-benefits). In Indonesia, the term co-benefits translate to mutual benefit and approach used in the pilot-scale project and the MoE in collaboration with JICA-OECC in 2010 at abattoirs (slaughterhouses) Gandung Palembang and Waste Landfill (Landfill) City of Banjarmasin and do not give further information regarding the indicators. To ensure a complete understanding and appropriate concepts, we use the term co-benefits in accordance with the concept of Puppim de Oliviera (2013).
} 
Meier, 2010; Puppim De Oliveira, 2013; Schwanitz, Longden, Knopf, \& Capros, 2015; Thambiran $\&$ Diab, 2011). Different notions have emerged in the literature when defining the concept of cobenefits. On the one hand, co-benefits aim to tackle local environmental problems and overcome global climate change problems at the same time. Those relate to climate change mitigation efforts from several sectors, such as transport, city planning areas, and the economic sectors of water, energy and health (Jack \& Kinney, 2010; Puppim De Oliveira, 2013). This concept was developed in the Third Assessment Report issued in 2001 by the Intergovernmental Panel on Climate Change (IPCC); the scientific panel from many countries addressing climate change. This co-benefits concept also derives from the concepts of environmental externalities (Yedla \& Park, 2009).

The concept of 'Sustainable Cities' (Bulkeley et al., 2009) addresses how to manage cities in better ways to cope with climate change (mitigation and adaptation) and to focus more on enabling actual spatial transformation, rather than institutional change only (Bulkeley, 2003; Bulkeley \& Betsill, 2013). In practice, low carbon cities have been used as a concept for mitigating climate change in developed countries, particularly in household energy management (Angelidou, 2014; Bulkeley \& Betsill, 2013).

Policy-makers, researchers, academics, and practitioners view the concept of co-benefits as an alternative win-win solution to manage local environments to reduce GHG emissions in climate change mitigation (Bollen, Johannes. C; Brink, C.J.; Eerens, H.C.; Manders, 2009; Dubash, Raghunandan, Sant, Sreenivas, \& Dubash, Navroz K; Raghunandan, D; Sant, Girish; Sreenivas, 2013; Hamilton \& Akbar, 2010; Ministry of Environment Japan, 2012). As an illustration, it is estimated that, for 2050 climate change mitigation actions, the cost estimates for the stabilisation at $710 \mathrm{ppm} \mathrm{CO}_{2}$-eq or reduced to $445 \mathrm{ppm} \mathrm{CO}_{2}$-eq, will equate to a $1 \%$ to $5.5 \%$ decrease in global GDP relative to baseline (IPCC, 2007). For many developing countries dealing with local problems, the implementation of climate change mitigation policy is beyond their means; notwithstanding the fact that few cities in developing countries have actually implemented this kind of policy (Puppim De Oliveira et al., 2013; Shrestha \& Pradhan, 2010; Thambiran \& Diab, 2011).

Various problems occur in Bandung managing the transport sector and its response to climate change (mitigation). As a consequence, several international, national, and local policies have been developed to tackle the climate change issues. The policy implementation comprises decisions that often overlook co-benefits as an ultimate target (such as a better environmental condition).

In this thesis, policy implementation is recognised as a process that "refers to the connection between the expression of governmental intention and actual results" (O'Toole, 1995). The climate policies stipulated by the government have the tendency to be ignored, particularly at the local level. In response, Van Meter \& Van Horn (1975, p. 465) argued that, to make the implementation effective "requires that a program's standards and objectives be understood by 
those individuals responsible for their achievement". In this situation, communication and enforcement activities are needed to enhance policy implementation. Other scholars seek similar criteria, such as effective communication, adequate resources, supportive dispositions of the implementer (officials), and wider participation (Edwards, 1980; Sabatier \& Mazmanian, 1980).

To support the development and implementation of policies that simultaneously lower GHG emissions and address local environmental issues needs research of the policy process. Contextual interaction Theory (CIT) is used as a theoretical framework for this research (Bressers, 2004, 2009). The CIT assumes the implementation processes are multi-actor interaction processes driven by the actors involved (Bressers \& Kuks, 2003). The key characteristic of the actors in the interaction process fulfils the criteria of the effectiveness of the implementation policy mentioned above.

The author has chosen the CIT framework as it can elaborate the specific interaction that affects the implementation process and associate these with the characteristics of the governance context (The theoretical framework is explored further in Chapter 2).

\subsection{Problem Definition}

In Indonesia, the climate change mitigation effort is based on the National Action Plan on reducing GHG (RAN-GRK), as mentioned in the Presidential Decree No. 61 Year 2011. This shows that the forestry sector and the peatland sector are the main sectors targeted for GHG emissions reduction $\left(88.6 \%\right.$ or equivalent to 0.672 Giga ton $\mathrm{CO}_{2} \mathrm{e}$ ); followed by waste management $(6 \%)$, energy and transport (5\%), agricultural (1\%), and industry (0.13\%). Although energy and transport come in third place, the urban areas are the largest contributor of GHGs emission, especially in Java (Bappenas, 2012). Emission from the transport sector have increased twofold over 10 years (DNPI, 2010) with the major source being in Bandung City ( $61 \%$ or $1395 \mathrm{Gg} \mathrm{CO}_{2}$ equivalent from road transport). Transport is also the sector contributing the most to air pollution, particularly from the intensive use of motor vehicles $60-88 \%$ (BPLH, 2013). The air quality from roadside monitoring shows an annual increase (by 4-8 times) in the concentrations of hydrocarbon, $\mathrm{PM}_{10}$ and $\mathrm{CO}$ (in particular $\mathrm{PM}_{10}$ exceeded the WHO standard) (BPLH, 2014).

Other problems for the mitigation effort of GHG emissions are a lack of clarity in how to measure GHG emissions (reduction potential) and a lack of information about co-benefits (IGES, 2011). Lack of awareness and differences in priority of the sectors are others barriers in promoting cobenefits (Yedla \& Park, 2009). A regional action plan (RAD-GRK) to reduce GHG for Bandung City exists. However, integrating mitigation policies into the development plan (except for the sectors from the Anggaran Pendapatan dan Belanja Negara (APBN) or the central government budget) has been problematic.

The transport sector has also been held responsible for the rising cost of health care and loss of (general) welfare (Monzon \& Guerrero, 2004). Furthermore, economic loss has been attributed to traffic congestion (Guo, Cheng, Chen, Zhou, \& Wang, 2010). A 2010 study from the Ministry of 
Environment (in collaboration with UNEP - USEPA) showed that 57.8 percent of Jakarta residents suffer from various diseases attributable to air pollution. The health related costs incurred are up to 38.5 trillion rupiah; equivalent to 3.2 billion dollars (Samantha, 2013). Total losses due to traffic congestion in Bandung City have reached 4.63 trillion rupiah; equivalent to 0.4 billion dollars (Bappeda, 2011). Moreover, road transport also contributes to death and disability, as reported by the WHO in 2001. This report found the transport sector responsible for more than 85 percent of death by accidents, whilst nearly $90 \%$ of accidents went on to lead to (permanent) disability (Peden, Krug, \& Mohan, 2001).

Implementing climate co-benefits transport policies in Bandung City are expected eventually to improve conditions, not only in reducing GHGs, but also tackling the loss of economic productivity, liveability and reducing environmental problems and creating other advantages, such as the opportunity for flexible mechanisms ${ }^{8}$ (Dubash et al., 2013; Jack \& Kinney, 2010; Puppim De Oliveira, 2013; Samantha, 2013; West et al., 2013). The co-benefits approach is suitable for several reasons (Dubash et al., 2013). First, it addresses local issues, such as environment, health, economic and social. Furthermore, it contributes to a global level response to mitigate climate change. The Kyoto Protocol emphasises that developed countries have a moral obligation to reduce GHG emissions (UNFCCC, 1998). In this sense, mitigation efforts prioritised by developed countries could take place in developing countries within a flexible mechanism.

Dubash, et al. (2013) illustrated GHG emissions reduction in developed countries and climate change mitigation actions implemented in India. In this action plan, development goals were addressed simultaneously. There was a mutual agreement ${ }^{9}$ between those countries bonded in the international negotiation process, including funding. This was confirmed by a report from the Japan Overseas Environmental Cooperation Centre in 2008. This stated that climate change mitigation activities that included co-benefits actions also spurred improvement of environmental quality in a number of other ways, such as air quality, water quality and waste management of CDM projects.

In Bandung, research into climate change mitigation in transport sector has been very limited. Most such research is in the form of inventory emissions. As an example, Driejana (2011) studied the contribution of vehicles to GHG emissions. The results showed that cars contributed mostly

\footnotetext{
${ }^{8}$ There are three mechanism under Kyoto protocol namely clean development mechanism (CDM), emissions trading, and joint implementation. All mechanisms indirectly related to the provision of funds on climate change mitigation (UNFCCC, 1998)

${ }^{9}$ In CDM projects, the government or a company of one of the developed nations having a GHG reduction target can invest in a project developed by an entity in a developing country (Host Countries). The investor then receives certified emission reductions (CERs) that verified by an independent accreditation agency. Host Countries (HC) have to set up a process of approval of these projects. The HC approval basically ensures that project meets criteria (climate change mitigation) decided by the Government of that country (Deodhar, Vinay; Michaelowa, Axel; Krey, 2003).
} 
to $\mathrm{CO}_{2}$ emissions and motorcycles mostly to $\mathrm{CH}_{4}$ emissions. This study also showed the loading factor on arterial roads ${ }^{10}$ in Bandung City that could characterise the traffic density.

The characteristic public transport services include: the minibus service (paratransit; also known as 'angkot') and motorised transportation (also known as 'ojek'). They are known to emit a substantial amount of $\mathrm{CH}_{4}$ and $\mathrm{CO}_{2}$. However, non-motorised transportation (NMT) tricycles (also known as 'becak') are also known as zero carbon emissions (Joewono \& Kubota, 2005). Analysis revealed that NMT and paratransit have many other benefits, since they provide mobility for women, students, low-income users and job opportunities for people with limited skills and education. Therefore, these means of transportation are highly accepted by the community, even though paratransit ${ }^{11}$ service performances were considered as not satisfactory (Tarigan, Susilo, \& Joewono, 2014).

Tamin (2005) conducted a study of Bandung Metropolitan public transport where the system must be an integrated transport network in the planning, implementation, and operations. His study combined four factors: (1) the highway system as an improved network of toll roads, arterial and feeder ${ }^{12}$; (2) the primary public transit system's fast network / high capacity transit route; (3) a secondary public transportation system, which features a rail / road-based public transport and a wide network with the feeder to the main transit system and general urban communities; and, (4) access to a local transport system that continues from the existing system of mini-buses, motorcycles, and tricycles. However, this study did not investigate any relationship with climate change mitigation policy, co-benefits nor any strategy to achieve low carbon transport.

The evaluation of climate co-benefits in the transport sector has not been measured thoroughly. The evaluation emphasised improving fuel efficiency of public transport. The current programme on sustainable transport in Indonesia (arranged by IGES (2014) shows that many of the plans have failed concerning climate co-benefits (Jaeger, Nugraha, Zusman, Nakano, \& Daggy, 2015). From 24 provinces $^{13}$, the projects were characterised as: 'avoid' strategy (3\%), 'shift' strategy (30\%) and 'improve' strategy (67\%). The programmes primarily implemented the BRT, regeneration of public transport, and developing intelligent transport system. The provinces appeared more inclined to propose low-cost 'improve' strategies than 'avoid' and 'shift' options. It is difficult to discern the reasons. However, funding constraints appeared in many provinces. Besides these

\footnotetext{
${ }^{10}$ Road classification or hierarchy based on function within planning of transport network. Arterial roads connecting between national center activities or to regional center activities (DPPW, 2004)

${ }^{11}$ Paratransit in metropolitan Bandung is fully in the private domain (Tarigan et al., 2014)

${ }^{12}$ Arterial mean the main road that connect to toll road; feeder function is connecting residential areas to arterial networks (Tamin, 2005)

${ }^{13}$ The Bus Rapid Transit projects that existed in Indonesia have been evaluated. There are three strategies to adopt from the IGES concept. Of the 34 provinces, only 24 provinces have submitted their information
} 
difficulties, the assessment suggested that monitoring the programmes and also fortifying the design specifically to integrate public transport and spatial planning could be the solution.

The case of bus improvement initiatives in Indonesia (Jakarta, Yogyakarta, Palembang City and Bogor City), Dirgahayuni (2012) evaluated the implementation of policy instruments in the transport sector into two types: physical measures (technology and network design) and soft measures (aim to alter both users and non-users perspectives towards using public or managing users barriers). Others instruments, such as regulatory framework and operational performance, were also measured.

Regarding the physical measures, the four cities encountered difficulties in expanding the service capacity and increasing the number of vehicles, providing bus priority systems, and optimising the network (including financial sharing for shelter construction; technical barriers such as land availability, narrow roads). However, the implementation of soft measures was still lacking (multimodal integrating and improvement). It also revealed that further studies should focus on identifying performance indicators and evaluate the intangible co-benefits of the initiatives at the local level (Dirgahayuni, 2012).

The major obstacles to furthering co-benefits have been identified in a study by Dirgahayani (2013). The results showed a lack of environmental co-benefits perspective in the policy-making process (e.g. in the Trans-Jogja bus system). The others obstacle were political and institutional barriers ${ }^{14}$ that need further analysis. The study suggested the potential to increase modal shift from private vehicle to public transport or active transport could benefit from tackling problems, such as traffic congestion, air pollution, and global climate change mitigation; even though there was still poor public transport performance. Research studies about shifting transport modes and how to change transport preferences for taking low carbon transportation is limited in Asia. This is particularly so in Indonesia (which has different characteristics when compared to developed countries).

Recent studies (Dirgahayani, 2013; Dirgahayuni, 2012; Driejana, 2011) have not shown a link between transport policy contributing to lower GHG emissions, particularly in preparedness of governance and users and non-users perspectives towards using public transport. Neither has there been for transport policy attaining co-benefits. For these reasons, it is important to study co-benefits goals (economic, social and environmental). Furthermore, selecting Bandung as a location of study is considered appropriate because it is seen as a very vulnerable city to climate change (second after Jakarta in the country) (DNPI, 2010). In addition, due to the geographical conditions of Bandung City in the Bandung basin, problems related to air pollution and climate

${ }^{14}$ From the 15 planned corridors only 3 corridors running; and the buses capacity only 54 exist from 120 buses that have been targeted in the plan. 
variability as a result of the "Urban Heat Island" phenomenon are expected to become more intense (Tursilowati, 2004).

Even though the Bandung Regional Development Medium Plan (RPJMD 2014 - 2018) has existed, air quality management policies have not associated with climate change mitigation. Environmental preservation efforts, increasing green open space areas, the so-called Blue-Sky Programme, Car-Free Day (CFD) activities, Bandung Green and Clean Programme, and the Trans Metro Bandung (TMB) project are but a few of the environmental management programmes initiated which allegedly link their benefits with climate change mitigation.

Bandung is a highly urbanised city. It has grown substantially in terms of population size (in 2012 this was 2.6 million) with recent indicators of strong economic growth $9 \%$ (2013) and $8.98 \%$ in the years 2008-2012 ${ }^{15}$. This compared with the national average of 5.8\% (BPS Kota Bandung, 2013). This trend goes hand-in-hand with increased growth numbers of vehicle used, as well as waste generation, lack of available land space, and water resources. The confluence of these factors creates complex environmental management problems. The question arises as to how the implementation of the climate change mitigation in transport sector exists and how this policy could contribute to and meet selected co-benefits goals?

\subsection{Research Questions and Study Objective}

The main objective of this doctoral study is to contribute to the understanding of the role of multiple actor characteristics and contextual factors in the current transport sector of climate change mitigation policies governance in Bandung City. This study will assess the climate change mitigation (environmental) policies in the transport sector policies that relate to lowering GHG emissions and meeting selected co-benefit goals.

The main research question is - how do actor characteristics, interaction between actors and contextual factors influence the implementation of climate change mitigation in the transport sectors and contribute to selected co-benefits? Following on from this - how can climate change mitigation policies in the transport sector be improved?

There are five sub questions to answer, as follows:

1. Which transport sector policies in Bandung City aim to contribute to lowering GHG emissions and contribute to selected co-benefits?

2. What qualities of the governance context and actor characteristics could have an impact on the effectiveness of the policies, as established in answering question 1, in lowering GHG emissions?

3. How can the specific context of the policies, as a result of the answering question 2, be improved further?

\footnotetext{
${ }^{15}$ Largest contribution in trade, hotels and restaurants (BPS Kota Bandung, 2013)
} 
4. How can the policies be improved to contribute to selected co-benefit goals?

5. How do actors perceive climate change policies with regards to their travel mode of choice?

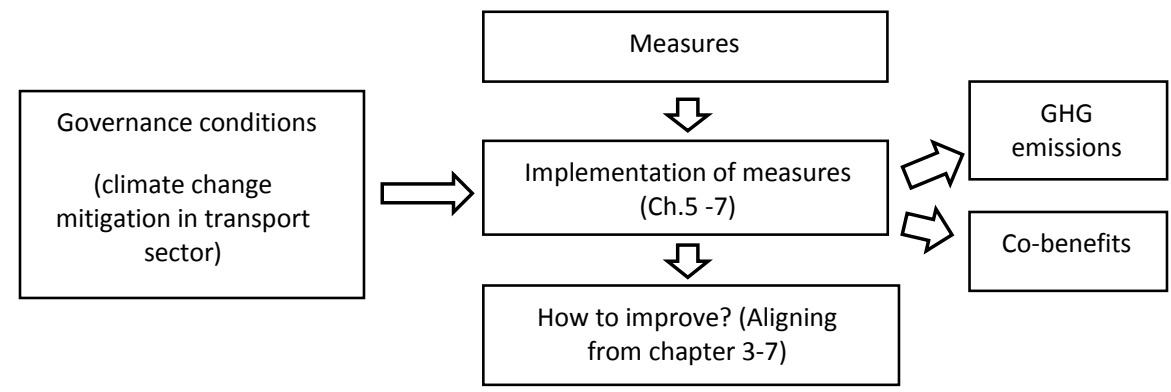

Figure 1.1: Flowchart of research planning stages and activities

Figure 1.1 presents the research planning stages and activities of this doctoral study. The research questions are answered in different sections. The research approach involves empirical studies on governance context in addressing climate change mitigation efforts to lower GHG by collaboration between multiple relevant public and private actors and stakeholders. Empirical studies involve: (1) evaluation of policy instruments and assessment of the relevant governance system (which involves analysing the degree of cooperation between stakeholders); (2) involves a behavioural analysis among transport users concerning attitudes, user preferences, behaviour, and willingness to change. The research supports the City of Bandung in designing an improved programme for the transport sector that can contribute to lowering GHG emissions substantially and meeting selected co-benefits ${ }^{16}$.

\subsection{Research Design and Methodology}

\subsubsection{Introduction}

General information about climate change mitigation and policies in Indonesia is needed to increase knowledge. This study used a mix of research methods that integrate qualitative and quantitative methods. This study assesses the transport sector and air pollution control as policy instruments in Bandung City and how these policies aim contribute to climate change mitigation.

To answer the main research question, the study was divided into three consecutive phases as described in the previous section. The first phase consisted of descriptive research of multiple

\footnotetext{
${ }^{16}$ Based on Bandung Regional Development Medium Plan (RPJMD 2014 - 2018) several activities targeting to lowering GHG emissions.
} 
case studies focused on the implementation of particular policy instruments. This phase is reported in Chapter 3. According to Stake (1995), case study research is an investigation and analysing of a single or a collective case with the purpose to gather the complexity of the object of study. According to Yin (2009, p. 18), "a case study is an empirical inquiry that investigates a contemporary phenomenon in depth and within its real-life context, especially when the boundaries between phenomenon and context are not clearly evident". The method used qualitative method with semi-structured interviews.

The results of this descriptive analysis were used in the second phase as the input to assess these policy instruments in terms of their effectiveness, the interaction processes of actors, and governance factors. These were conducted using interviews with actors (users and paratransit drivers). This second phase can be characterised as evaluative. The method for analysing the effectiveness of governance used qualitative research based on Governance Assessment Tools (GAT) as derived from CIT (see results in Chapter 4). In this phase, the research also conducted interviews with implementing actors (local government, paratransit owners, and drivers). This research was subject specific (as reported in Chapter 5) and used qualitative methods.

Table 1.1 illustrates how case study research compares with survey research strategy.

The third research phase conducted an analysis to supports Bandung City decision-makers in how to evaluate the low carbon co-benefits programme for the urban transport sector (reported in Chapter 6). This thesis selected evaluation criteria according to different aspects, such as policy outcome or goal attainment; and, social, economic, technology, transportation and environmental (Dubash, et al., 2013; UNFCCC, 2006; Tzeng, et al., 2005). The analysis of the private vehicle users as the target actor enriched the study of climate change mitigation in the transport sector using the Stern's Environmental Siginificant Behaviour Theory (Stern, 2000).

\subsubsection{The Phase Conducting a Case Study on the Implementation of Relevant Policy Instruments}

The first empirical study addressed the implementation of policies using a case study research approach (Chapter 3 ) and is descriptive in character. In this study, a 'what' question related to low carbon policy instruments in the Bandung transport sector is used, rather than a 'why' or 'how question. Firstly, the content of implementation and the context for implementation is characterised as it is expressed in the literature of sustainable urban transport and CIT. The concept of sustainable urban transport derives originally from that of sustainable development. It is said that transport sector, in particular, has to accelerate its transition to sustainable development. It should promote the use of renewable energy source and develop low-carbon transport. The strategies 'avoid', and 'shift', 'improve' derive from a study to understand transport sector activities that relate to climate change mitigation (GIZ, 2004). 
The second research question (Chapter 4) uses the GAT. The CIT, as the theoretical framework used in this case study, has some characteristics in answering the research questions. It examines the actor characteristic and the governance context in Bandung City and its relationship with other levels of government. The GAT is used to analyse the quality of governance. The third research question (Chapter 5 ) uses a qualitative approach and case study research with the CIT framework. How the policies contribute to selected co-benefits is addressed in a separate chapter (Chapter 6).

Subsequently, the underlying theory is described with respect to instrument and elements of the governance system. Primary data was collected to supplement secondary data by interviewing relevant stakeholders. The effects of instruments are described that address GHG emissions and selected co-benefits. All key elements in the governance system were addressed including: level and scales; actors and networks; perceptions and goals; tasks and resources; and strategies and instruments (Bressers \& de Boer, 2013).

\subsubsection{Survey on Behavioural Change in the Use of Transport Modes}

The case studies results were used to input data for a quantitative approach based on surveys amongst vehicle owners. The survey method focused on a willingness to change analysed the perception of the target actor in their relationship to the climate change programmes. The survey also researched the intention of actors to use and adapt their own travel modes. The respondents were owners of privately-owned vehicles in Bandung City (report in Chapter 7). The survey targeted vehicle users and their willingness to use the public transport (users that affected from existing programmes). Stern's environmental significant behaviour theory was used (Stern, 2000) for the descriptive statistical study. In the willingness to change survey, data analysis was conducted using non-parametric analysis (the statistical method in which the data is being distribution-free), as explained further in Chapter 7.

To justify the quantitative and qualitative approaches, each was used to supplement each other and cover for each other's weak spots (see Table 1.1).

Table 1.1: The supplement using of case study research and survey approaches. Source: Adapted from Gomm, Hammersley, \& Foster (2000)

\begin{tabular}{|c|c|}
\hline \multicolumn{2}{|c|}{ The characteristics (or benefits) of certain research designs } \\
\hline Case Study & Survey \\
\hline $\begin{array}{l}\text { - Small number of units (sometimes one) } \\
\text { Data collected and analysed about large and } \\
\text { often not predetermined features of each } \\
\text { unit } \\
\text { - Interest in naturally occurring features or } \\
\text { the variables in context } \\
\text { - Data can be quantitative, qualitative or both }\end{array}$ & $\begin{array}{l}\text { - Large number of units } \\
\text { Data collected and analysed about a small } \\
\text { number of features of each case } \\
\text { - Unit selected to represent characteristics of } \\
\text { the study's population } \\
\text { Data is usually quantitative }\end{array}$ \\
\hline
\end{tabular}


- Aim is of testing theory or evaluation of an intervention
- $\quad$ Aim is to generalise findings from sample to population

\subsection{Overview of the following chapters}

This thesis consists of eight chapters that progress as illustrated in Figure 1.2.

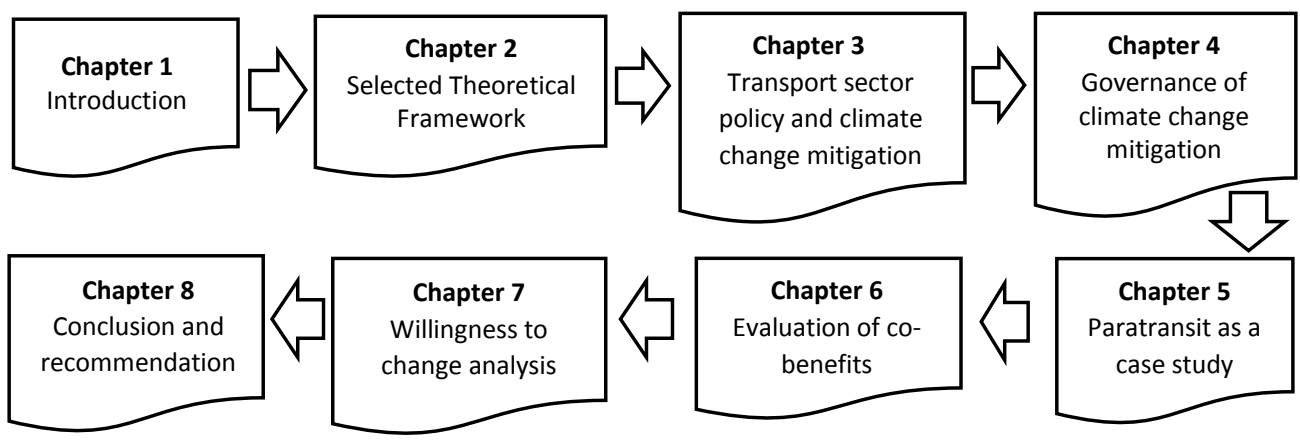

Figure 1.2: Thesis outline

The first chapter introduces the study and sets the scene. Chapter two presents the analytical framework that builds from the literature on governance in the policy implementation of climate change mitigation. This uses CIT and the GAT. Later on, this framework reinforced the behaviour theory discussion.

Chapter 3 provides the analysis description of the mitigation policy of Bandung City government. The local levels perceived several policy instruments as being relevant programmes or policies that could reduce GHG emissions, as analysed by the CIT framework (motivation, cognition, resources). This chapter was published at the 'Environments Journal' in June 2017.

Chapters 4, 5 and 6 present the results of case study research. Chapter 4 explains the governance system of climate change mitigation in Bandung City. This analysis used the GAT derived from $\mathrm{CIT}$. The chapter describes the development and current situation of mitigation activities in Indonesia at a national level, for West Java as a provincial level and for Bandung City at a local level. Chapter 4 answers the question of which transport policies in Bandung City aim to contribute to lower GHG emissions. The case selection of paratransit mode as a public transport in Bandung City is the subject of further research.

Chapter 5 introduces the governance interaction process and identifying of co-benefits. The case study examined different actors (particularly paratransit driver). The interaction of different actors in Bandung City and different levels of transport sector is assessed using CIT analysis of paratransit governance. 
Chapter 6 examines the evaluation of co-benefits based on urban climate policy. This research adopts a basic rating scale. The criteria chosen evolved from literature reviews.

Chapter 7 analyses travel modes choice and vehicle user's attitude and behaviour concerning climate change policies. It presents the results of a survey conducted among owners of privately owned vehicles. This chapter conducted the survey amongst target actor vehicle users. The thesis evaluated the alternatives of policy instrument from the actor's perspectives.

Chapter 8 brings together conclusions of the empirical chapters to answer the main research questions. This chapter also addresses the empirical and theoretical contribution of the thesis to the academic bodies of knowledge and policy recommendations. 


\section{Chapter 2: Theoretical Frameworks}

\subsection{Introduction}

This chapter explains how this thesis understands and uses the CIT (Bressers, 2004) as its framework to study the implementation process of governance in climate change mitigation. This study also elaborates on how the policy instruments were perceived by actors; these being implementers and a target group (Owens \& Bressers, 2013). The study analyses the quality of governance and identifies local level improvements for implementers to meet certain goals. CIT) is mainly used in Chapters 3, 4 and 5.

Behaviour theory is also used to support this framework. We make use of the behaviour theory from Stern (2000), which is used for the survey reported in Chapter 7. The CIT gives attention to the cognitions and motivation of the actors involved. In our survey, we investigate these for our group of vehicle drivers in more depth. Developing a policy to encourage a target group to change their behaviour relies on discovering the explaining factor of their behaviour and to find those methods that can effectively influence their behaviour. This framework is needed to assess and explain how the target group perceive their situation and their willingness to change their use of public transport.

\subsection{Policy Implementation}

This study uses theory on how policies or programmes are implemented. The literature on implementation theory indicates that models have developed a top-down approach (Jeffrey \& Wildavsky, 1973; Sabatier \& Mazmanian, 1980; Van Meter \& Van Horn, 1975), a bottom-up approach (Elmore, 1980; Hjern \& Porter, 1981; Lipsky, 1980) and newer theories as synthesizers (Goggin, Bowman, Lester, \& O'Toole, 1990; Matland, 1995; O’Toole, 1986; Rothstein, 1998; Scharpf, 1978). Different views and methodological perspectives on policy show pivotal considerations of authority and legitimacy as to how implementation problems are viewed.

The top-down policy perspective has become known as the first generation of classical implementation theory. This conceives implementation as a singular one-way flow. Definition of implementation as formulated by Mazmanian and Sabatier (1983 p.20) said, "Implementation is the carrying out of a basic policy decision, usually incorporated in a statute but which can also take the form of important executive orders or court decisions". Ideally, that decision identified the problem(s) to be addressed, stipulated the objective(s) to be pursued, and in a variety of ways, "structured" the implementation process (Hill \& Hupe, 2002).

Another example of top-down implementation research can be seen in the Pressman and Wildavsky (1973) book that researched a case study of the implementation of the Economic Development Administration (EDA) in the United States. They stated "implementation is worth studying precisely because it is a struggle over the realisation of ideas. It is the analytical equivalent of original sin, there is no escape from implementation and its attendant responsibilities" (Jeffrey \& Wildavsky, 1973, p. 180). In the later edition of Implementation, Pressman and Wildavsky also asked why governments did not learn from their mistakes. In this case study, the evaluation stage was used as a tool to better understand what went wrong and what worked. 
However, in our study that focuses on the climate change mitigation policy already established by the national level, the implementation of the policy instruments at the local level goes beyond examining just the policy instruments; the evaluation is also beyond the input-output process. The advantage of the top-down approach is that it developed policy advice and consistent patterns in behaviour across different policy areas (based on central level perception). However, local actors and their views were not taken these into consideration (Matland, 1995).

Michael Lipsky (1971 and 1980) researched the bottom-up orientation. Benny Hjern (1982) proposed that street level bureaucrats were the key to successful implementation and that the top downers overlooked that. The proponents argued that the bottom-up actors were better able to capture the full range of implementation complexity. Hjern's strategy was to study a policy problem, asking the micro level actors about their goals, activities, problems, and contacts. He found that the national level initiatives were poorly adapted to local conditions (Matland, 1995). The strengths of this approach were its focus on centrally located actors (who implement government programmes). Thus, contextual factors within the implementing environment are important. However, shortcomings appeared from the power derived from actor accountability and this approach tended to overemphasize the level of local autonomy (Matland, 1995).

The comparison between the two approaches shows the change of perspectives of researchers. However, there are strengths and weaknesses for each of these two approaches. Sabatier (1986) attempted to synthesize the two approaches, while O'Toole (2000) observed that different ways of looking at the same phenomenon "moved past the rather sterile top-down, bottom-up dispute" (DeLeon \& DeLeon, 2002).

Matland (1995) tried to synthesise the two approaches under the ambiguity-conflict model of policy implementation. We explain it here briefly to give just one example of an implementation theory that goes beyond the bottom-up/top-down division. Also, CIT (more about that later) is labelled as a so-called 'third generation' implementation theory (Owens \& Bressers, 2013). The four paradigms of policy implementation are: low conflict-low ambiguity (administrative implementation); high conflict-low ambiguity (political implementation); high conflict-high ambiguity (symbolic implementation); and, low conflict-high ambiguity (experimental implementation). This matrix helps to sort various recommendations.

Table 2.1: Ambiguity -Conflict Matrix: Policy Implementation Processes. Source: Matland (1995)

Conflict

Low

High

\begin{tabular}{|c|c|c|}
\hline 3 & $\begin{array}{l}\text { Administrative implementation } \\
\text { Resources } \\
\text { Example: smallpox eradication }\end{array}$ & $\begin{array}{c}\text { Political Implementation } \\
\text { Power } \\
\text { Example: Busing }\end{array}$ \\
\hline$\frac{\sqrt{\underline{\underline{a b}}}}{\overline{\underline{x}}}$ & $\begin{array}{l}\text { Experimental implementation } \\
\text { Contextual conditions } \\
\text { Example: Head start }\end{array}$ & $\begin{array}{c}\text { Symbolic Implementation } \\
\text { Coalition Strength } \\
\text { Example: Community action agencies }\end{array}$ \\
\hline
\end{tabular}


Matland's (1995) theory has central principles for each box. For administrative implementation, the central principle is the outcomes to be achieved that are determined by resources. An example of this is when the World Health Organisation (WHO) established the programme to eliminate smallpox. Success was determined by the resource availability and the efficiency of the programme to implement the policy.

CIT is another example of an implementation theory that goes beyond the top-down versus bottom up divide. It starts with the assumption that there is a multiplicity of actors and that their interaction shape the implementation and effectiveness of policies. As stated by (Bressers, Bressers, \& Larrue, 2016, p. 46) about the implementation of the policies "It views implementation processes not top down, as just the application of policy decisions, but as multiactor interaction processes that are ultimately driven by the actors involved. Thus, it makes sense to explain the course and results of the process from that simple starting point and to place these actors and their main characteristics central stage in any analytical model".

(Bressers et al., 2016, p. 47) continue: "there is a dynamic interaction between the key actor characteristics that drive social interaction process and in turn are reshaped by the process". Eventually, in the theories of policy implementation, the role of actors is of critical importance. Research on how policy implementers and target groups interact address their motives, cognitions and their resources. Using the CIT (Bressers, 2009), the interaction process between the local level in Bandung City and other actors are mapped in a wider context, the structural context, and local context in which climate change mitigation was addressed. In CIT, there are three actor characteristics, viz. motivation, cognitions, and resources. As mentioned by O'Toole (2004) regarding CIT, 'core circumstances' (the characteristics of the actors involved) and 'external circumstances' (the various layers of context) were distinguished.

\subsection{Contextual Interaction Theory (CIT)}

CIT was developed as a theory of implementation in the Netherlands (during the 1990s). It has been used in several studies. CIT analyses the core of implementation based on: motivation, cognitions and resources (Bressers \& de Boer, 2013). The implementer is the actor "officially commissioned with promoting the envisaged measures" and the target is the "actor necessary to realise (the measures)", such as citizens or companies (Owens \& Bressers, 2013).

CIT has been used for various types of sectors including: water, energy, and health (Casiano \& de Boer, 2015; Djellouli \& Quevedo-Gómez, 2015; Gana \& Hoppe, 2017; Jain, Hoppe, \& Bressers, 2017). Knowing motivation, cognitions, and also resources (that provide capacity and power of the actors) one can predict or explain interaction processes in the implementation of projects (Bressers et al., 2016; Bressers \& de Boer, 2013; Owens, 2008). The original flowchart showed that actors consist of the implementer and target group. Some later research has also characterised actors into three: implementing actors, target actors and linking actors (Mohlakoana, 2014). Various combinations of independent variables indicated the nature of the interaction process between actors including: motivation, cognitions (information), and resources (power and capacity). 


\subsubsection{The Basics}

CIT is useful for policy implementation analysis by comparing the feasibility of implementation and effectiveness of different policy instruments (Bressers, 2009). The definition of implementation states that implementation consists of "the process(es) that concern the application of relevant policy instruments, including the realisation of projects to achieve physical changes (building, infrastructure, landscaping). The relevant activities and interactions are pursued for one part by actors - organisations and people - that are officially commissioned with promoting the envisaged measures (the implementer), and for another part by actors that are necessary to realised them (often so-called the target groups)" (Bressers, 2004, p. 284). The actions of the actors take place in a setting of thee three actor characteristics (motivation, cognitions, and resources) and how, over time, they emerge in the social interaction processes as the main variables of the implementation process. There are variables in every layer of context that can influence the process by acting on one or more of these core variables. This approach aligns well with the third generation (synthesizing) thinking about the policy implementation processes.

\subsubsection{Actor Characteristics as Core Characteristics}

In clarifying the variables of motivation, cognitions, and resources central in the $\mathrm{CIT}$, there is an illustration (Bressers \& Kuks, 2003, p. 14). "First look at what is needed to make a relatively simple object: making a chair requires the carpenter to have an object in mind, and it requires expertise and resources, such as tools and materials. In multiple -actor process goals also relate to the position relative to other actors as well as do information and resources (the last providing power). A second way of clarifying the three perspectives is to link them to ideas on policy instruments. Policy instruments are often classified into rules, incentives and communication. This, in our opinion, does not so much reflect different policy instruments but different ways in which they exert their influence. A third way of illustrating their rich significance is to relate the three perspective even broader to social science disciplines".

In order to understand the backgrounds and interrelatedness of the three actor characteristics, Bressers developed the model below. 


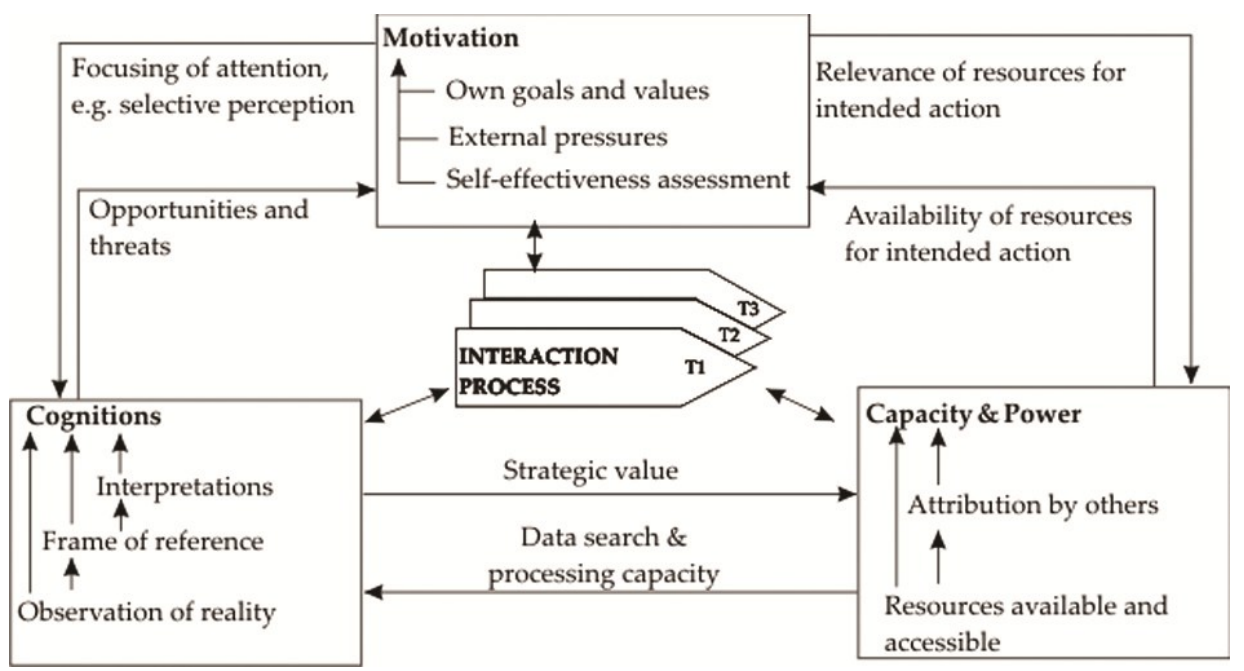

Figure 2.1: Dynamic interaction between the key actor-characteristics that drive socialinteraction processes and, in turn, are reshaped by the process.

Source: Bressers $(2007,2009)$

This model is more flexible in use than the flowcharts that directly link combinations of actor characteristics of implementers and targets to implementation results that Owens has used, but lacks its predictive value (Bressers, 2004; Owens \& Bressers, 2013).

The motivation box shows the types of actor motivators: i.e. an actor's own goals and values, external pressures and self-effectiveness. Cognitions derive from the actor's interpretations, frames of reference, and observations of reality. Capacity and power consist of attribution by others and resources available and accessible.

In this theoretical framework, the actor characteristics (motivation, cognition, resources) are in dynamic interaction. Motivation influences, or can be influenced by, cognition and resources. To exemplify this, it could affect the capacity and power through actor's relevance of resources for expected action, .... and vice versa ...., the capacity and power can affect the motivation of the actor because, for certain preferred actions, the actor needs the resources to be available. If not available, the actor, in turn, can get demotivated.

\subsubsection{The External Contexts}

The key actor characteristics are not only intrinsic to them and affected by the dynamic interaction process, but also they are influenced by external factors from a multi-layered context. In CIT, layers of context, namely specific context, structural context and wider context, influence the dynamic interaction process of actors.

The CIT framework focuses on actors and their characteristics, as well as on the interrelations with other contexts, particularly the structural and wider context. Figure 2.2 illustrates the interaction process between actors within the layers of context as explained below. 


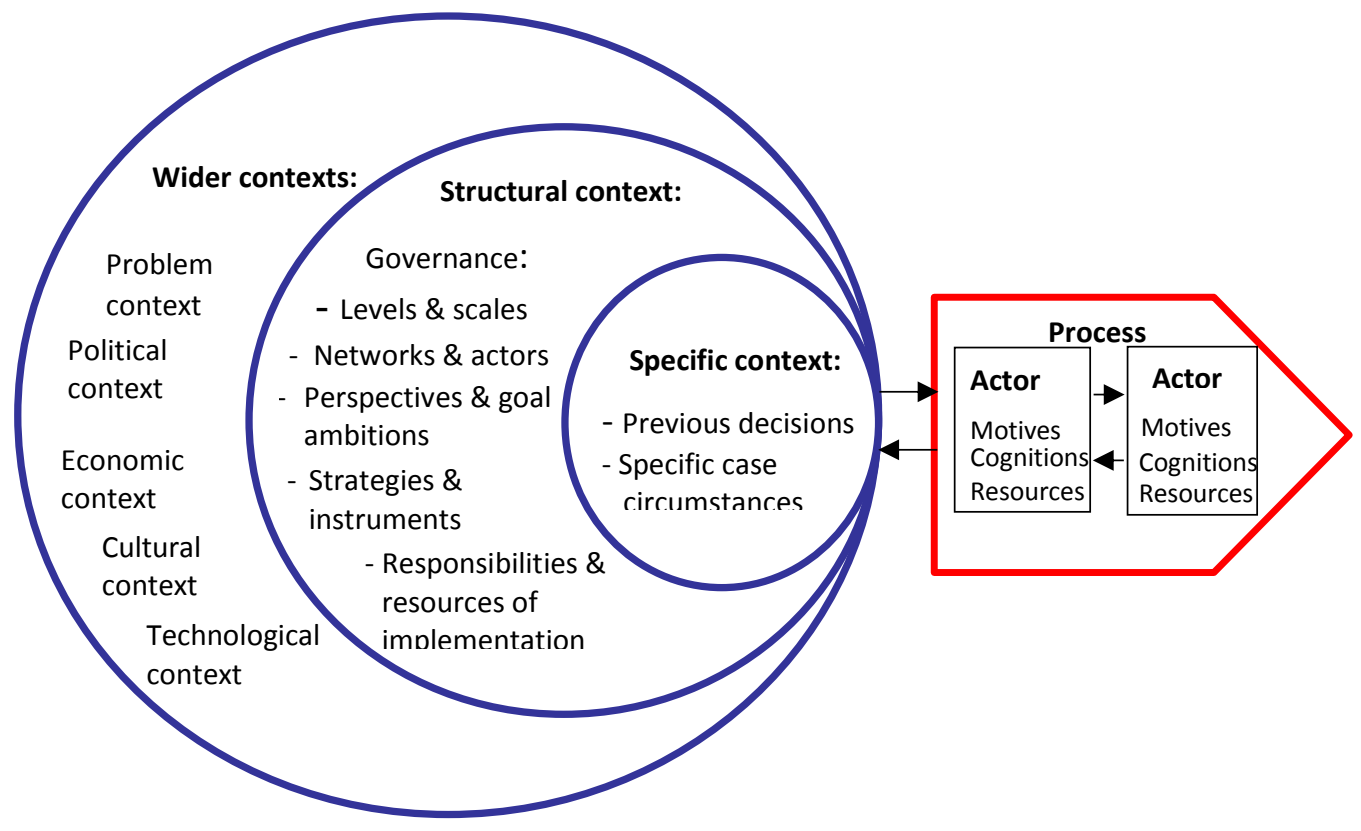

Figure 2.2: Contextual Interaction Theory.

Source: Bressers (2009, p. 13)

\subsubsection{The Wider Context}

The wider contexts consist of elements of a problem, be this political, economy, cultural and technology or even global in nature, such as the problems and technological advances around climate change. The innovation literature describes in social-technical external factors as part of the exogenous contextual landscape. These include demographical trends, political ideologies, societal values, and macro-economic patterns (Geels, 2011, p. 28). An example of how the wider context influences other layers and actor characteristics might be the influence of economic crises on the resources (for instance, allocation funds) to economic policy instruments and restrictions of financial resources for the actors.

\subsubsection{The Structural Context}

The structural context consists of elements of governance. The literature often refers to these as a regime context. This layer includes governance structure and property rights on the natural 
resources. Several implementation studies scholars have acknowledged governance in context. Rothstein (1998) in Hill \& Hupe (2002) divided government measures into operative conditions. The concept of governance focused on understanding how the multi-level character become the essential part of governance study (O'Toole, 1986). Others literature shows that the governance concept to be a broad term used in many different ways (Milward \& Provan, 200017; UN, 200718; Ostrom, 199019). The formation of European Union stimulated governance to become the subject of studies by several researchers ((Bache, 2010; Hooghe \& Marks, 2001). The types of governance by Hooghe \& Marks (2001) were divided between type I, referring to greater regionalisation of state structures, and that promoted pluralisation of policy-making processes. However, studies on the quality of governance are lacking in previous research.

Rhodes (1996) studied the term 'governance' embraced six uses: the study of minimal states, corporate governance, new public management, good governance, socio-cybernetic systems, and self-organising networks. These are similar to Bulkeley et al., (2009) who researched how governance was being applied to climate change problems. The study on climate change in Bandung City showed possible government action with the initiative by the Institute for Global Environmental Strategies (IGES) as an international research institute.

However, governance as a structural context layer in CIT framework has five elements (Bressers \& Kuks, 2003, p. 7), as follows :

1. "Levels (not necessarily administrative levels): governance assumes the general multilevel character of policy implementation

2. Actors in the policy network: governance assumes the multi-actor character of policy implementation

3. Perception of the problem and objectives (not just the objectives): governance assumes the multi-faceted character of the problems and objectives of policy implementation

4. Strategies and instruments: governance assumes the multi-instrumental character of policy strategies for policy implementation

5. Resources and organisation of implementation: governance assumes the complex multi-resource basis for policy implementation".

The descriptive questions to be used to assess policy implementation processes in the structural context (Bressers, 2009, p. 126) are as follows:

${ }^{17}$ Governance is an inclusive term, its essence on focusing the governing mechanisms (grants, contracts and agreements) and do not only tend to authority and sanctions of government (governance in a hollow state)

18 Governance diverse can be isolated into three main types: political or public governance; economic governance; and social governance. (Nzongola \& Ntalaja, 2003 in UN, 2007). The UN more focuses on good governance in combating the shortcomings.

${ }^{19}$ Governing the commons as the tittle of book by Eleanor Ostrom considered how societies have developed diverse institutional arrangements for managing natural resources and avoiding ecosystem collapse in many cases 
"Multiple levels and scales. Which levels of governance dominate the policy discussion? What is the accepted role of government at various scales? Which other organisations are influential in the governance activities on these levels? Who decides or influences such issues? How is the interaction between various levels of governance organised?

Multiple actors in the policy network. How open is the policy arena? Open to whom and where, precisely? What role do experts play? How do the various governmental and other organisations relate to each other?

A multiplicity of problem definitions and goal ambitions. What are the dominant maps of reality? What is seen as the problem and how serious is this considered to be? Where are the recognised points of intervention? What are the goal ambitions in relevant policies? Where coordination is required with other fields of policy, what are the links accepted by the actors?

Multiple instruments -- possibly even belonging to more than one relevant policy strategy. Which (other) instruments belong to the relevant strategy or strategies? What are the target groups of the instruments, and what is the timing of their application? What are the characteristics of these instruments (see above)?

Multiple responsibilities and resources for implementation. Which organisations (including government organisations) are responsible for implementing the arrangements? What is the repertoire of standard reactions to challenges known to these organisations? What authority and other resources are made available to these organisations by the policy"

The questions above can serve to describe the various elements of governance, but do not yet help to understand whether they supportive implementation or not. For this assessment, four criteria were developed, as will be explained below: extent, coherence, flexibility and intensity. Our research uses the GAT to answer the quality of the governance in the climate change mitigation in transport sector, especially in Chapter 4.

\subsection{Governance Assessment Tool as Part of CIT}

In this thesis, we analyse the governance pattern and quality of the policies for climate change mitigation in Bandung City. Governance is a very broad concept and at every level has both vertical and horizontal tiers. The literature on this concept evolved into multi-level governance. This thinking is amplified in analysis of European Union as an integration of several nations (Hooghe \& Marks, 2004).

Two distinct types of multi-level governance appear in the literature (Hooghe \& Marks, 2001). Type I describes the reallocation of authority among a limited number of governments operating at just slight tiers (for example, within a federal system: the federal government, state government and local government). Type II describes vast jurisdictions that are not aligned on few levels, that operate at diverse territorial scales, and functionally have specific jurisdiction involving actors involving not just government (Bulkeley \& Betsill, 2005; Hooghe \& Marks, 2001). 
Multi-level governance can contribute to a fruitful analytic framework to assess climate change governance (Bulkeley \& Betsill, 2005; Harker, Taylor, Knight-Lenihan, \& Knight-Lenihin, 2017). Bulkeley characterises the climate change governance based on mitigation adaptation programme at the urban cities (Bulkeley et al., 2009). It investigates how the paradigm of topdown approach to climate changes. Environmental governance was proposed for climate change mitigation in multi-level governance.

Bressers (2009) used five elements of governance; the multi-level being one. In CIT, governance forms the structural context layer (governance context). In addition to this essentially descriptive model, the GAT was developed to include four additional quality criteria. This tool has been used in several water governance fields to assess the supportiveness of the water governance regime for the realisation of certain policies and measures (Casiano \& de Boer, 2015; Owens, 2008). More recently, it has been used in other fields, such as energy efficient buildings in India (Jain et al., 2017). The four quality criteria are:

a. Extent: are all relevant aspects taken into account?

b. Coherence: are all aspects reinforcing rather than contradicting each other?

c. Flexibility: are multiple roads to the goals, depending on opportunities and threats as they arise, allowed and supported?

d. Intensity: the degree to which the regime elements urge changes in the status quo or in current developments

The full GAT consists of a matrix in which specific questions define the precise meaning of each cell:

Table 2.2: Main evaluative questions of Governance Assessment Tool.

Source: Bressers et al. (2013)

\begin{tabular}{|l|l|l|l|l|}
\hline \multirow{2}{*}{$\begin{array}{l}\text { Governance } \\
\text { dimension }\end{array}$} & \multicolumn{3}{|c|}{ Quality of the governance regime } \\
\cline { 2 - 5 } & Extent & Coherence & Flexibility & Intensity \\
\hline Levels and & $\begin{array}{l}\text { How many levels } \\
\text { scales } \\
\text { are involved and } \\
\text { dealing with an } \\
\text { issue? Are there any } \\
\text { important gaps or } \\
\text { missing levels? }\end{array}$ & $\begin{array}{l}\text { Do these levels work } \\
\text { together and do they } \\
\text { trust each other } \\
\text { between levels? To } \\
\text { what degree is the } \\
\text { mutual dependence } \\
\text { among levels } \\
\text { recognised? }\end{array}$ & $\begin{array}{l}\text { Is it pove up and down } \\
\text { levels (up scaling } \\
\text { and downscaling) } \\
\text { given the issue at } \\
\text { stake? }\end{array}$ & $\begin{array}{l}\text { Is there a strong } \\
\text { impact from a } \\
\text { certain level } \\
\text { towards } \\
\text { behavioural } \\
\text { change or } \\
\text { management } \\
\text { reform? }\end{array}$ \\
\hline
\end{tabular}




\begin{tabular}{|c|c|c|c|c|}
\hline $\begin{array}{l}\text { Actors and } \\
\text { networks }\end{array}$ & $\begin{array}{l}\text { Are all relevant } \\
\text { stakeholders } \\
\text { involved? Are there } \\
\text { any stakeholders } \\
\text { not involved or } \\
\text { even excluded? }\end{array}$ & $\begin{array}{l}\text { What is the strength } \\
\text { of interactions } \\
\text { between } \\
\text { stakeholders? In what } \\
\text { ways are these } \\
\text { interactions } \\
\text { institutionalised in } \\
\text { stable structures? Do } \\
\text { the stakeholders have } \\
\text { experience in working } \\
\text { together? Do they } \\
\text { trust and respect each } \\
\text { other? }\end{array}$ & $\begin{array}{l}\text { Is it possible that } \\
\text { new actors are } \\
\text { included or even } \\
\text { that the lead shifts } \\
\text { from one actor to } \\
\text { another when there } \\
\text { are pragmatic } \\
\text { reasons for this? Do } \\
\text { the actors share in } \\
\text { 'social capital' } \\
\text { allowing them to } \\
\text { sup-port each } \\
\text { other's tasks? }\end{array}$ & $\begin{array}{l}\text { Is there a strong } \\
\text { pressure from an } \\
\text { actor or actor } \\
\text { coalition } \\
\text { towards } \\
\text { behavioural } \\
\text { change or } \\
\text { management } \\
\text { reform? }\end{array}$ \\
\hline $\begin{array}{l}\text { Problem } \\
\text { perspectives } \\
\text { and goal } \\
\text { ambitions }\end{array}$ & $\begin{array}{l}\text { To what extent are } \\
\text { the various problem } \\
\text { perspectives taken } \\
\text { into account? }\end{array}$ & $\begin{array}{l}\text { To what extent do the } \\
\text { various perspectives } \\
\text { and goals support } \\
\text { each other, or are } \\
\text { they in competition or } \\
\text { conflict? }\end{array}$ & $\begin{array}{l}\text { Are there } \\
\text { opportunities to re- } \\
\text { assess goals? }\end{array}$ & $\begin{array}{l}\text { How different } \\
\text { are the goal } \\
\text { ambitions from } \\
\text { the status quo or } \\
\text { business as } \\
\text { usual? }\end{array}$ \\
\hline $\begin{array}{l}\text { Strategies and } \\
\text { instruments }\end{array}$ & $\begin{array}{l}\text { What types of } \\
\text { instruments are } \\
\text { included in the } \\
\text { policy strategy? Are } \\
\text { there any excluded } \\
\text { types? Are } \\
\text { monitoring and } \\
\text { enforcement } \\
\text { instruments } \\
\text { included? }\end{array}$ & $\begin{array}{l}\text { To what extent is the } \\
\text { incentive system } \\
\text { based on synergy? Are } \\
\text { trade-offs in cost } \\
\text { benefits and } \\
\text { distributional effects } \\
\text { considered? Are there } \\
\text { any overlaps or } \\
\text { conflicts of incentives } \\
\text { created by the } \\
\text { included policy } \\
\text { instruments? }\end{array}$ & $\begin{array}{l}\text { Are there } \\
\text { opportunities to } \\
\text { combine or make } \\
\text { use of different } \\
\text { types of } \\
\text { instruments? Is } \\
\text { there a choice? }\end{array}$ & $\begin{array}{l}\text { What is the } \\
\text { implied } \\
\text { behavioural } \\
\text { deviation from } \\
\text { current practice } \\
\text { and how } \\
\text { strongly do the } \\
\text { instruments } \\
\text { require and } \\
\text { enforce this? }\end{array}$ \\
\hline $\begin{array}{l}\text { Responsibilitie } \\
\text { s and resources }\end{array}$ & $\begin{array}{l}\text { Are all } \\
\text { responsibilities } \\
\text { clearly assigned and } \\
\text { facilitated with } \\
\text { resources? }\end{array}$ & $\begin{array}{l}\text { To what extent do the } \\
\text { assigned } \\
\text { responsibilities create } \\
\text { competence struggles } \\
\text { or cooperation within } \\
\text { or across institutions? } \\
\text { Do the main } \\
\text { stakeholders consider } \\
\text { them legitimate? }\end{array}$ & $\begin{array}{l}\text { To what extent is it } \\
\text { possible to pool the } \\
\text { assigned } \\
\text { responsibilities and } \\
\text { resources as long as } \\
\text { accountability and } \\
\text { transparency are } \\
\text { not compromised? }\end{array}$ & $\begin{array}{l}\text { Is the amount of } \\
\text { allocated } \\
\text { resources } \\
\text { sufficient to } \\
\text { implement the } \\
\text { measures } \\
\text { needed for the } \\
\text { intended } \\
\text { change? }\end{array}$ \\
\hline
\end{tabular}

The questions above can be used as guidelines to address the quality of the governance. However, sometimes it is hard to measure and quantify all of them. To some degree, it is unavoidable that the scores are based on 'informed judgements'. Therefore, the scores for each cell most often just classified into three divisions: supportive, neutral or restrictive. 


\subsubsection{The Specific Case Context}

Apart from the 'wider contexts' and the 'structural context' or governance context explained above, CIT also discerns a 'specific context'. The structural context and wider context, such as at the national level, are likely to be more stable than the specific case context that contains more aspects of the concrete cases studied. In contrast to the specific context, both are not actorspecific, but often are homogeneous for all cases. The implementers at the local level have less influence on the structural or wider context, than on the specific context. Therefore, the specific case context also has an important part in knowing about climate governance at the local level.

In the $\mathrm{CIT}$, the specific context layer consists of previous decisions and the specific circumstances of the cases. The previous decisions are studied through analysing the case history. This is essential to understand the actors' interaction and their action. This implies examining the previous policy decisions and experiences in relevant environmental fields and the transport sector that could have shaped the existing policies in Bandung City.

In general, the urban city problems, such as city expansion that contribute to the dense population and demographic explosion in Bandung City, could vary between different cities. Air pollution problems are caused by the crowdedness of people and motorcycles. However, Bandung lies in a Basin and this particular geographical condition increases the problem. Other factors that vary and contribute will include the economic and political background, which motivate people to change their mode of transport or governance in transport sector.

\subsection{Environmental Psychology and Behavioural Theory}

Alongside using CIT and GAT, we also use psychological theory, especially as a background for the survey we report on in Chapter 7. The reason is that, while CIT does include some motivational factors, we need greater insight into these when studying travel mode choice with a questionnaire.

A conceptual framework on behavioural analysis regarding travel mode choice was introduced by Scheiner \& Holz-Rau (2007), Gardner \& Stern (2002), Steg \& Vlek (2009) and Stern (2011). Environmental significant behaviour (ESB) theory (Stern, 2000) is used in this research to focus on the factors that contribute to change of travel mode and, thereby, climate change mitigation. This theory looks at the direct effect of behaviour on limiting climate change by improving understanding of climate-friendly actions, as well as the impact of policy interventions to reduce carbon emissions. The ESB theory addresses our seventh research question. It also complements the answer to the fourth research question. When conducting the survey of willingness to change in travel mode choice (reduce of car user), this theory helps policy actors to know what determinant factors contribute to the lowering of greenhouse gas emissions by the target actors in the transport sector (private car user). However, changing from one mode of transport to another is not an automatic, easy-going process. 
ESB theory can make a meaningful contribution to limiting the impact of climate change by enhancing our understanding of human behaviour that drives climate change. It also allows us to learn from adaptation to climate-related technologies and policies, and to turn this understanding into effective policy instruments (Stern, 2011). The theory of environmental significant behaviour by Stern (2000) "can be defined by its impact: the extent to which it changes the availability of materials or energy from the environment or alters the structure and dynamics of ecosystems or the biosphere itself". How this theory is connected to the main framework of this research CIT could be explained by the basic assumption of CIT that acknowledges the outcome of the policy process as being dependent on the input (characteristic of policy instruments) and the key characteristics of the actors involved (Bressers, 2004).

Vehicle drivers, as target actors, are already distinguished as a cause of GHG emissions (human activities). Egmond, Jonkers, \& Kok (2006) noticed that policy instruments to lower GHG emissions should address specific groups of actors (segments of target groups). There is some evidence that attitudes on the environment are reflected in travel behaviour to some extent, but that it has some difficulties to establish causality. For example, one survey (Golob \& Hensher, 1998) on commuter attitudes and behaviour on policies to lower GHG emissions found mode choice may also affect attitudes (positively or negatively) through their experience using the mode. There was no causal link between the tendency to use public transport and the attitude concerning the GHG emissions problems. However, there was a link from choice of public transport to intention to reduce travel.

Users or passengers have degrees of freedom when using transport modes. A number of barriers can be identified by user preference or characteristics of using public transport and private car. These barriers are related to the take-up of environmental modes of transport (low carbon strategies). Using public transport is recognised as a strategy to lower GHG emissions (Bongardt et al., 2013; Creutzig et al., 2012). A study of user perceptions on the public transport and private car by Beirão \& Sarsfield Cabral (2007) found certain factors that intervened with the policy outcomes (see table 2.3).

Table 2.3: Motivations and barriers to public transport use. Source: Beirão \& Sarsfield Cabral (2007, p. 478)

\begin{tabular}{ll}
\hline \multicolumn{1}{c}{ Motivations } & \multicolumn{1}{c}{ Barriers } \\
\hline Better service & Not having alternative to car \\
\hline Conformity with the timetables & Lack of direct transport \\
\hline Direct transport from home to work & Lack of availability of buses \\
\hline More travel information available and easy to understand & Long travel time \\
\hline Save money & Buses' unreliability \\
\hline Not having a parking space for private vehicles & Do not known what to expect \\
\hline More comfort and air-conditioning on vehicles & Need for multiple journeys \\
\hline Contribute to a better environment & Poor information \\
\hline & Not frequent enough \\
\hline
\end{tabular}




\begin{tabular}{ll}
\hline Motivations & \multicolumn{1}{c}{ Barriers } \\
\hline & Bus stop too far \\
\hline & Buses are smelly and crowded \\
\hline Feeling of personal insecurity \\
\hline Having to use more than one transport \\
\hline Bad waiting conditions \\
\hline Negative feeling towards public transport \\
\hline
\end{tabular}

The research showed that, in order to increase public transport usage, the service should be designed to attract potential users. The study also suggested that the market segments for public transport were based on the actors' motivation to change and willingness to reduce the frequency of car use (Beirão \& Sarsfield Cabral, 2007).

Shifting from a private mode of transport to another would meet more difficulties. To avoid emissions through reducing traffic in urban areas that occasionally depend on the use of private transport has encouraged the government to increase the use of public transport (International Energy Agency, 2016). The public may be unwilling to take action for the greater benefit, unless there is some form of fiscal incentive or punishment (Collins, Thomas, Willis, \& Wilsdon, 2016). In developing countries, such as Brazil and India, shifting from private road transport to buses has the possible co-benefits to reduce congestion, accidents, travel costs, and emissions. However, this transformation would not only be changing behaviour, but also value systems. As such, tradeoffs exist (Tilburg, Würtenberger, Coninck, \& Bakker, 2011).

There are two possibilities regarding any behaviour to become pro-environmental. Stern informs us that there are two possible definitions of environmental significant behaviour from the actor's standpoint, namely: (1) impact-oriented; and (2) intent-oriented behaviour (see Stern, 1999). The definition of the impact-oriented behaviour is the extent to which it changes the availability of material or energy from the environment, directly (such as clearing forest, disposing household waste), or indirectly (such as tax policies, affect international development policies). The intentoriented focus from the actor standpoint is their intention to change or benefit the environment. The intent-oriented definition highlighted the environmental intent as an independent cause of behaviour (Stern, 2000). In the theory of planned behaviour (TPB), this intent-oriented becomes the primary factor to the planned behaviour (Ajzen, 1991). Adopting impact-oriented behaviour in the research and identifying the target actors can make positive outcome for the environment (Gardner \& Stern, 2002).

Other research has found that travel mode choice was based on five key elements: life situation, lifestyle, location attitudes, location choice/urban form, and travel behaviour (Scheiner \& HolzRau, 2007). Other individual factors, such as background variables (e.g., gender, age, income, and number of cars in the household) and internal motivational factors (economic, health, 
environmental motivation, beliefs) can contribute to change in travel mode choice or use of other vehicles (Eriksson, Nordlund, \& Garvill, 2010).

In low or middle-income countries, internal motivation factors could be explained by studying the level of economic development and vehicle ownership. From the relationship between the level of economic development, motorcycle and car ownership, studies show that economic development strongly affects the ownership of private vehicles in two ways (Pongthanaisawan \& Sorapipatana, 2010). First, the overall number of private vehicles increases. This is due to a rise in economic levels (hence, incomes and welfare level) and growth in population size. Second, after a certain level of income growth, people will shift from motorcycle to car ownership. This is for reasons of prestige, convenience, comfort or safety. In Bandung City, it is rather motorcycle ownership that has increased, as compared to the car ownership, because vehicle owners tend to possess various private vehicles that can be used for a certain number of activities. The increasing risk of ending up in traffic jams is one reason why people in Bandung tend to prefer the use of motorcycles to cars.

The effectiveness of behavioural interventions generally appears when policies remove barriers (limiting factors). Encouraging pro-environmental behaviour, such as active travel (De Nazelle et al., 2011; Rabl \& de Nazelle, 2012) such as using bike or walk as a non-motorised transport, depends on certain principles. Gardner and Stern (2002) list a set of principles on how to intervene when targeting environmental behavioural change (See Table 2.4).

Table 2.4: Principles for intervening to change environmentally destructive behaviour. Source: Gardner \& Stern (2002, p. 159)

\begin{tabular}{|c|c|}
\hline A. & $\begin{array}{l}\text { Use multiple types of interventions to address the factors limiting behaviour change } \\
\text { 1. Limiting factors are numerous (e.g. technology, attitudes, knowledge, money, convenience, } \\
\text { trust); } \\
\text { 2. Limiting factors vary with actor and situation, and over time; } \\
\text { 3. Limiting factors affect each other. }\end{array}$ \\
\hline B. & Understand the situation from the actor's perspective. \\
\hline c. & $\begin{array}{l}\text { When limiting factors are psychological, apply understanding of human choice processes } \\
\text { 1. Get the actors attention; make limited cognitive demands; } \\
\text { 2. Apply principles of community management (credibility, commitment, face-to-face } \\
\text { communication). }\end{array}$ \\
\hline D. & Address conditions beyond the individual that constrain pro-environmental choice. \\
\hline E. & Set realistic expectations about outcomes. \\
\hline F. & Continually monitor responses and adjust programmes accordingly. \\
\hline G. & Stay within the bound of actor tolerance for intervention. \\
\hline H. & Use participatory methods of decision-making. \\
\hline
\end{tabular}

Based on Table 2.4, user preference of target actors (e.g. people using different modes of transport in Bandung City) can be assessed by understanding the situation from the actors' 
perspectives using a survey research design. It is possible, for example, to survey a representative sample of the target group to analyse why target group members do, or do not, use public transport or another proposed active transport means (walking or cycling) that is less harmful in terms of $\mathrm{CO}_{2}$ and $\mathrm{PM}_{10}$ or $\mathrm{PM}_{2.5}$ emissions.

1. Attitudinal

- General environmentalist predisposition (VBN theory) \& behaviour-specific norms (norm-activation theory)

- Non-environmental attitudes (e.g., about product attributes)

- Perceived costs and benefits of action

2. Personal capabilities

- Literacy

- Social status and power

- Financial resources

- Behaviour-specific knowledge and skills

3. Contextual factors (external forces)

- Material costs and rewards

- Law and regulations

- Available technology

- Social norms and expectations

- Supportive policies

4. Habit and routine

Figure 2.3: The independent variables used for survey willingness to change. Source: Stern (2000)

The principle of intervening to change behaviour in this study applies to multiple intervention strategies (hence, policy instruments) to address the factors limiting behavioural change. Often, multiple barriers prevent one from adopting pro-environmental behavioural alternatives. Government programmes that combine different types of intervention have more potential to attain pro-environmental behavioural change than programmes that only rely on monointervention strategies (Gardner \& Stern, 2002).

In figure 2.3, the dependent variable environmental significant behaviour was examined as a possible result of environmental values, environmental knowledge, and demographics. The key hypothesis was to establish a positive relationship between all independent variables and environmental significant behaviour, as mentioned in figure 2.3. The attitudinal factors, such as values, beliefs, and norms, are the causal variables in the theory of significant behaviour. In Stern's theory, these factors are stated as the general environmentalist's predisposition. Values commonly are related to the important goals or standards in guiding principles of life (Ajzen, 1991). The personal commitment and the perceived personal costs and benefits of particular 
actions contribute to this factor (Steg \& Vlek, 2009). This variable has explained the type of environmental behaviour on travel mode of choice that also relate with the willingness to change of car users (Bamberg, Fujii, Friman, \& Garling, 2011; Bamberg \& Schmidt, 1999).

The second type of causal variable consists of personal capabilities. In the Stern's theory, these include knowledge and skills. However social demographic factors also contribute to these causal variables, such as income and employment, that contribute the personal capabilities (Bamberg et al., 2011; Stern, Dietz, Abel, Guagnano, \& Kalof, 1999). In reference to the research of car ownership, car use and public transport, the influence of demographic, socio-economic and landuse factors influenced the people on their use of all of the independent variables, such as income, gender, household size and working place (Dargay \& Hanly, 2004; Feng, Fullerton, \& Gan, 2013; Golob \& Hensher, 1998).

In terms of environmental literacy, as a factor that contributed to environmental behaviour as an ultimate goal, there was a general opinion that environmental education did not have much effect. However, the results suggested that, if the environmental education is taken into account, the research should focus on increasing the constructive attitudes (Eilam \& Trop, 2012).

Contextual factors may facilitate environmentally significant behaviour of the actor. The quality of public transport, the regulation that can hamper the use of vehicles, and the available technology that make public transportation more efficient, could be the factors to encourage environmentally significant behaviour and could be used in a low carbon strategy. In Stern's theory, several types of external forces come from the social, economic, and political context (e.g. the price of oil, the sensitivity of government to public or pressures from interest groups, and financial interest rates in the market) (de Groot \& Steg, 2007; Steg \& Vlek, 2009; Stern, 2000). Also, advertising and supportive policies could motivate people to act to constrain or encourage environmental behaviour.

Habit or routine activity is a causal variable that triggers much behaviour. People who choose a travel mode regularly tend to use that transport mode as an option in the future (Schneider, 2013). Changing from old habits and creating a new routine activity is needed to achieve the intended behaviour. "The standard operation procedure is also a key factor in environmental significant organisational behaviour" (Gardner \& Stern, 2002, p. 418). There are some cases where behaviour is habitual and guided directly by cognitive processes, rather than by being led by elaborate reasoning (Steg \& Vlek, 2009, p. 312). In order to modify habitual environmental behaviour, Steg \& Vlek (2009) found that, in designing effective intervention, one needs to know how the habits were formed, reinforced and sustained.

The other factor to be acknowledged in modifying environmental significant behaviour is the socio-demographic background. In line with the pro-environmental behaviour studies, the research on how to change travel modes, researchers have scrutinised the role of sociodemographic features in motivating sustainable urban transport. Three demographic factors have been found to influence environmental attitudes and pro-environmental behaviour: gender, education, and income. The longer the period of education, the more extensive is a person's 
knowledge about environmental issues. However, it does not mean that their pro-environmental behaviour also increases (Eilam \& Trop, 2012; Kollmuss \& Agyeman, 2002). The use of public transport in developing countries usually targets lower income households. In planning transport systems, the challenge is to evaluate the proportion of income spent by lower-income households on public transport alongside land-use planning. However, there is a paradox that, in many emerging cities, lower-income urban residents still cannot afford public transport. Poor people have to spend more than a fifth of their income on public transport (Carruthers, Dick, \& Saurkar, 2005).

In general, when seen from a gender perspective, women use more trips by bus, on foot and as car passengers than men (Hanlon, 2000). The bus is the most used mode of transport for young and older women, with two-thirds of all bus users being women. Women make more local trips and undertake travel more often than men. A survey conducted in Asia (Japan, Thailand, China, Vietnam, Philippines and Indonesia) by Van, Choocharukul, \& Fujii (2014) found the contributions of attitude variables in explaining the intention to use a car were larger than those for public transit. This implies that the behavioural intention to use a car, compared to public transit, was strongly related to attitudes. However, that survey had more males than females, except for the samples from Philippines and China. The survey showed that gender and car ownership were significant coefficients as behavioural factors when selecting a personal mode of transport. "Specifically, female respondents and respondents owning a car were more likely to intend to use the car for their future work trips. Though such a result might not be the same for females in European countries, it could be reasonable for Asian countries where public transport services are generally overcrowded (like in Tokyo, Japan) and chaotic (like in other developing countries). Women might have certain feelings of insecurity when using public transit. Such fears of being harassed might overwhelm thinking about difficulties in manoeuvring a car, thus cause women's stronger intentions to use a car than men's" (Van, Choocharukul, \& Fujii, 2014, p. 40).

\subsection{Conclusion}

Relevant theory in policy studies and environmental psychology were introduced and reviewed in this chapter. The actors have a central role in third generation policy implementation theories. The CIT framework focuses on actor interaction in a dynamic setting and uses various layers of context, such as the structural governance context that is assessed with the help of the GAT.

Therefore, the use of the CIT in this study is highly appropriate to show how the policy process takes place and whether the quality of governance is supportive for particular outcomes. As a basis for the survey questionnaire, environmental significant behaviour theory developed by Stern (2000) was used to supplement the CIT in finding factors that can influence the choice of travel modes. 


\title{
Chapter 3: Incorporating Air Quality Improvement at a Local Level into Climate Policy in the Transport Sector: A Case Study in Bandung City, Indonesia
}

This chapter is based on: Gunawan, H., Bressers, H., Mohlakoana, N., Hoppe, T., 2017. Incorporating Air Quality Improvement at a Local Level into Climate Policy in the Transport Sector: A Case Study in Bandung City, Indonesia. Environments, 4, 45, 1-17

\begin{abstract}
Climate policy has a strong influence on policy processes at national levels in Indonesia, while other policies with a focus on air quality improvement are being implemented at local levels. Indonesia, as a developing country, has committed to reducing greenhouse gas (GHG) emissions by 29 percent by the year 2030. This calls into questions the extent to which cities and local governments can cope with the challenges of climate change mitigation. The purpose of the research is to find out the extent to which local air pollution reduction policies can contribute to the climate change mitigation programme. The research design involved an empirical case study on governance and policy relevant to climate change efforts to lower GHG in Bandung City, Indonesia. The study evaluated the air quality improvement and the climate change mitigation programmes using the actor-based framework of the Contextual Interaction Theory (CIT). The governance and stakeholder characteristic of climate change mitigation were also analysed using the structural context part of the CIT framework. The result shows that air quality improvement policy is implemented separately from climate policy; the latter operates at the national level and the former at the local level. By looking at the actor interaction analysis, the study concludes that a more holistic environmental policy approach would be more efficient at reducing local air pollution and contributing to the mitigation of climate change.
\end{abstract}

\subsection{Introduction}

Global climate change, environmental degradation, poverty, the lack of availability of water and food due to population density pressures are factors that magnify disasters. These should be avoided, mitigated and thoroughly managed, particularly in developing countries (MoE, 2007; UNFCCC, 2007; Watson et al., 2001). Rapid population growth and broadening of human activities have had a detrimental effect on the climate because of anthropogenic emission sources.

Transportation is one sector that emits greenhouse gases (GHGs) and contributes significantly to climate change and air pollution. Increasing motor vehicle use in cities, particularly in developing countries, increases fuel consumption and, thus, GHGs emissions. It is difficult to reduce these $\mathrm{CO}_{2}$ emissions since so many primary economic activities rely on it. Worldwide, the transport sector contributes $26 \%$ of global $\mathrm{CO}_{2}$ emissions and is one of the few sectors where emissions are still growing (Chapman, 2007).

Another problem is air pollution. The latter primarily results from a steep increase in vehicle use. Every year, the number of vehicles in Bandung City (the third largest city in Indonesia) has increased $10-15 \%$. Meanwhile, the increase in road construction has been at $0.45 \%$ per year (BPS 
Kota Bandung, 2015). This has inevitably led to congestion in Bandung City (Bigazzi, 2011; Eldewisa \& Driejana, 2008). This problem is exacerbated by a lack of green open spaces $( \pm 7.86 \%$ of the total Bandung City area - far less than legally binding target of 30\%) (BPLH, 2013). The transport sector is also responsible for rising health care costs and for a loss of general welfare (Monzon \& Guerrero, 2004). Furthermore, economic loss attributable to traffic congestion (Guo et al., 2010) has reached 4.63 trillion rupiah per annum (equivalent to \$US 0.4 billion) (Bappeda, 2011).

Other related problems are a lack of clarity in measuring GHG emissions (a potential reduction in each action) and a lack of information about co-benefits (IGES, 2011). The co-benefits are defined as benefits to the local environment because of mitigation actions/adaptation in addressing global environmental change (Puppim De Oliveira, 2013). A lack of awareness and differences in the priority given to sectors are other barriers to promoting co-benefits (Yedla \& Park, 2009).

Several concepts of global climate change and local air pollution control have received increased attention in academic literature, e.g., sustainable urban transportation (Goldman \& Gorham, 2006; Greene, D.L; Wagener, 1997). Another approach, which deals simultaneously with both the global and the local problems, is the so-called co-benefits approach (Creutzig et al., 2012; Jack \& Kinney, 2010; Lee \& Van De Meene, 2013; Nemet et al., 2010; Puppim De Oliveira et al., 2013; Schwanitz et al., 2015; Thambiran \& Diab, 2011). The concept of 'Sustainable Cities' (Bulkeley \& Betsill, 2013) also addresses how cities can govern better to cope with climate change and focus on enabling actual spatial transformation, rather than only institutional change (Bulkeley, 2003; Bulkeley \& Betsill, 2013). In practice, low-carbon cities have been used as a concept to mitigate climate change in developed countries, particularly in household energy management (Angelidou, 2014; Bulkeley \& Betsill, 2013). The co-benefit approach is a suitable focus for action (Dirgahayuni, 2012; Puppim De Oliveira et al., 2013). It could support an integrated programme to develop and implement policies that simultaneously contribute to lowering GHG emissions, while, at the same time, addressing local social-economic sustainability challenges.

In this paper, the main research question is how the role of governance becomes effective to incorporate air pollution control. The policy also benefits the reduction of GHG emissions mitigation in the transport sector of Bandung. It signals that local governments apparently give little attention to mitigating climate change, but do mitigate air pollution. The paper examines to what extent air pollution policies can contribute to climate change mitigation in Bandung City.

The paper is divided into five sections. The next section (Section 2) reviews the relevant literature on air pollution control that address climate change (mitigation) or low-carbon governance by cities and on co-benefits. The theoretical aspects of the CIT (Contextual Interaction Theory) framework are presented in the third section. The CIT framework is used to analyse climate governance in the Bandung City transport sector case. This is analysed further with the structural context for governance analysis. The research design and methods are discussed in the fourth section. The fifth section presents the results of the Bandung City case study, together with a discussion of them. The paper ends by drawing conclusions and making recommendations for future research. 


\subsection{Low-Carbon Transport Governance and Co-Benefits}

The 1987 Brundtland Commission report introduced the concept of sustainable development. Here stakeholders have to collaborate to implement its principles in the cities (Goldman \& Gorham, 2006). The concept of sustainable development led to new concepts, including: sustainable transport (Schiller et al., 2010), sustainable urban transport (Goldman \& Gorham, 2006), environmentally sustainable transport (OECD, 1997), sustainable low-carbon transport (Tilburg et al., 2011), sustainable cities (Bulkeley et al., 2009), and co-benefits (Bollen, Guay, \& Corfee-Morlot, 2009). The concept of sustainable transportation is multi-dimensional and encompasses three areas: (1) implementing technology; (2) pricing and financing; and, (3) integrated transport and land use planning (Goldman \& Gorham, 2006; Greene, D.L; Wagener, 1997; Schiller et al., 2010). Further research in policy implementation is necessary to understand how this concept was developed and integrated in the programme of climate change mitigation in Indonesia.

Bulkeley (2013) studied modes of governing in terms of the reduction of GHG emissions. A framework was used that was adapted from the UN Habitat report. There are seven modes of low-carbon governance that cities use (Bulkeley \& Betsill, 2013): (1) municipal self-governance; (2) municipal provision; (3) municipal regulation; (4) municipal enabling (predominantly governed by the municipality); (5) non-state voluntary; (6) public-private provision and (7) non-state mobilisation (private-sector actors). Governance approaches by local government include various forms of self-governance (e.g., staff travel planning, vehicle fleet fuel switching based on local readiness), regulations (e.g., emissions standards, planning laws), provision (e.g. of public transport service or infrastructure for alternative modes of travel), enabling (e.g. information) and partnerships (e.g., public-private financing for new modes of transportation) (Bulkeley et al., 2009).

According to Bulkeley et al. (2009), there are four key motivations for climate policy and actions that local governments have: leadership, the stimulus from the central government to local governments, resources and issue framing. In terms of leadership, Bulkeley et.al, (2009) found that individual political 'champions', such as the Mayor of Yogyakarta, are important actors supporting advance initiatives (e.g., a programme to retrofit lights and reduce air conditioning hours and bulbs, change travel behaviour, and developed BRT.

The stimulus of central governments (e.g. China and South Korea), has been a crucial factor in developing the political space (authority) for local government action on climate change (in public transport provision and street lighting). The available resources are also very important. This is exemplified in the Seoul case study. This illustrated how funds were allocated for climate change action to finance research, technology development and mitigation schemes, to support renewable energy and also to improve energy accessibility and promote greater energy efficient (Bulkeley et al., 2009).

Issue framing is considered a critical factor in climate change policy and action. First, it is important for energy security and fuel efficiency to help eradicate poverty. Second, framing low- 
carbon strategies, in terms of air quality and health problems, led to some initiatives by local actors in the transport sector in all the case studies described in this paper.

CIT (Bressers, 2009) addresses motivation as a key actor-characteristic that drives social interaction processes that the processes, in turn, reshape. However, resources are not part of the motivation, but are included as a variable on the actor characteristics.

Most cities in Indonesia face considerable barriers to address climate change. These are notably in coordinating policy action, obtaining resources, operating in national level frameworks that do not always facilitate local action (Jaeger et al., 2015), and in the often-conflicting aims of climate protection and economic growth (Bulkeley et al., 2009). Categories involving policies and mechanisms, cognitions and capacities have advantages and disadvantages. Bulkeley (2013) mentioned institutional, political and socio-technical factors as barriers and drivers of climate change mitigation efforts. The CIT framework treats these as the wider and structural context. These will be presented and discussed in the governance analysis framework.

\subsubsection{The Concept of Co-Benefits}

Local environmental issues - such as air quality, congestion, and health - are primary issues for governments to deal with. Therefore, there have been several attempts by local government to overcome the problems. Various notions have emerged in the literature to define the concept of co-benefits. On the one hand, some approaches aim to tackle local environmental problems and overcome the global climate change problems at the same time. These often involve climate change mitigation efforts from several related sectors, such as transport, city planning, and the water, energy and health sectors (Jack \& Kinney, 2010; Lee \& Van De Meene, 2013; Puppim De Oliveira et al., 2013). The Intergovernmental Panel on Climate Change (IPCC) developed this concept in the Third Assessment Report (2001). This co-benefits concept also draws on the concepts of environmental externalities (Yedla \& Park, 2009).

Co-benefit approaches refer to the development and implementation of policies and strategies that simultaneously contribute to mitigating global change, while addressing local environmental issues and the impact on other developments. The CIT framework is used to analyse the cobenefits based on the actor characteristics. Trying to implement climate change mitigation policy is often a step too far for developing countries struggling to deal with local problems. This is why few cities in developing countries actually implement such policies (Puppim De Oliveira, 2013; Shrestha \& Pradhan, 2010; Thambiran \& Diab, 2011). Understanding the importance of governance in helping urban areas cope with climate change can provide useful lessons when designing tools for analysing and evaluating urban climate change programmes. 


\subsection{Contextual Interaction Theory (CIT) Framework}

This paper uses actor-based research to address how effectively air quality policy has been implemented. The research addresses the programme instrument that also has the benefit of mitigating climate change. The literature suggests various approaches to implementing a policy model. They can be developed from top-down (Jeffrey L \& Wildavsky, 1973; Sabatier \& Mazmanian, 1980; Van Meter \& Van Horn, 1975), from bottom-up (Elmore, 1980; Hjern \& Porter, 1981; Lipsky, 1980) and from synthesizers (Goggin et al., 1990; Matland, 1995; L. J. O’Toole, 1986; Rothstein, 1998; Scharpf, 1978).

Differing views and methodological perspectives in policy researches show the pivotal considerations of authority and legitimacy as to how implementation problems are learned. Rothstein (1998) divided various government measures into operative conditions (M. Hill \& Hupe, 2002). According to O'Toole (Peters \& Pierre, 2006), the concept of governance emphasized understanding on how well the multi-level character became an essential part of governance study. Other literature showed that the concept of governance has been a broad one and used in many ways (such as governance in a hollow state (Milward \& Provan, 2000); governance in the UN that more focus in combating the shortcomings (United Nations, 2007); governing the commons as introduced by Ostrom (1990)). Governance of climate change was introduced by Bulkeley et.al, (2009) in her research.

Eventually, the theory of implementation will lead to research about the actors, including research on how implementers and the target interact with each other and their motives, cognitions and resources. The CIT from Bressers, (2009) can map actors' characteristic in different layers. The interaction process maps relationships between the local level in Bandung City and other actors (both vertical and horizontal). It then divides them between various contexts (the wider context, structural context and specific context). The context based on actor interaction is influential in addressing climate change mitigation (Fig. 3.1) as we explained previously in section 2.3 regarding the CIT Framework. 


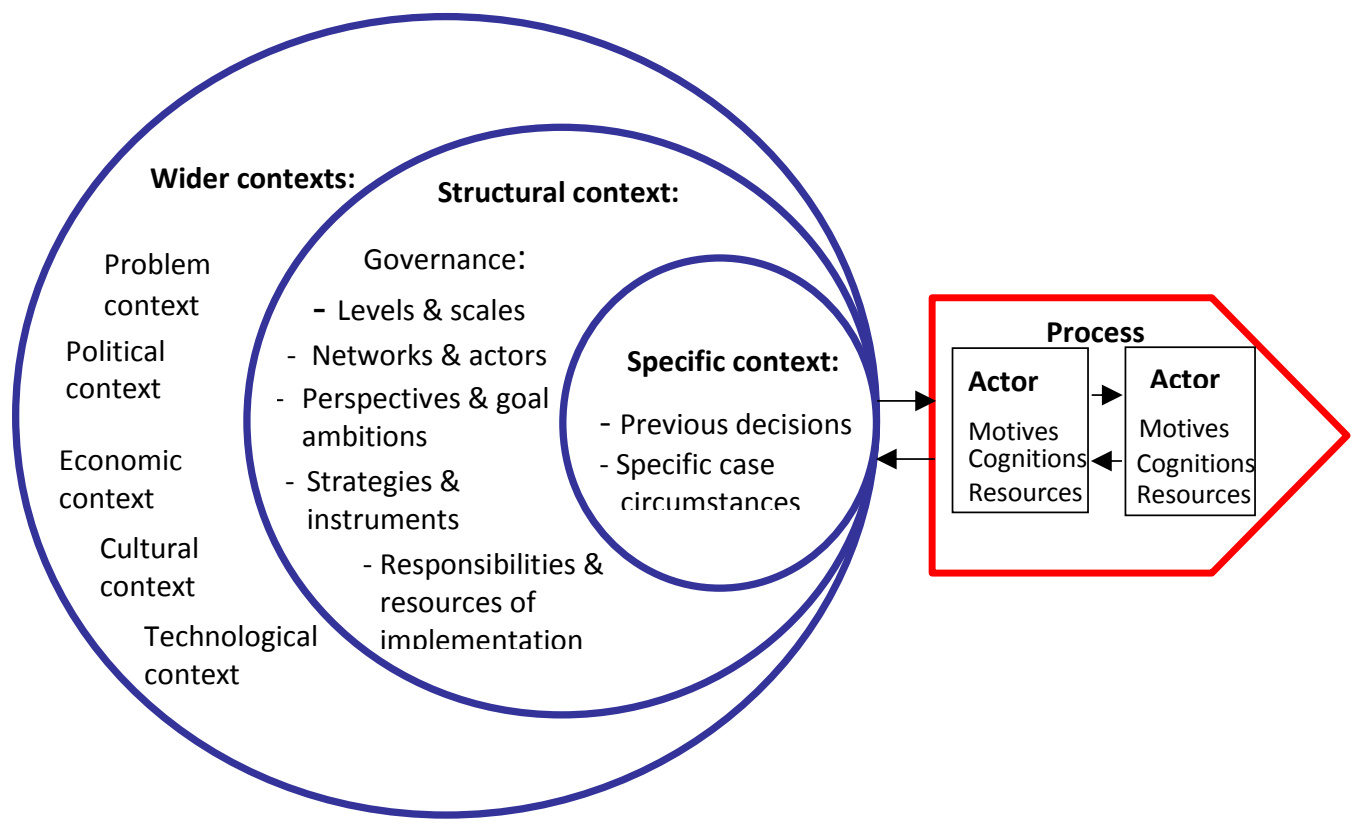

Figure 3.1: Contextual Interaction Theory. Source: Reproduced with permission from Bressers (2009)

Research into the central role of actors (characteristics) to explain the interaction processes is crucial to CIT. It focuses on three core characteristics: motivation-cognitions-resources - as defined by Bressers, (2009), and as a refinement of motivation, information and power (Bressers, 2004). The structural context consists of elements of governance linked with relevant property and use rights. The wider context consists of elements of problem, political, economic, and cultural and the technological content (fig.3.1). CIT was developed as a theory of implementation. It has been used mainly in studies analysing policy in the environmental context and sustainable development, mostly in developed countries (Mohlakoana, 2014). Lately, this framework has been more widely used in developing countries (Casiano \& de Boer, 2015; Mohlakoana, 2014). The implementer is the actor who is "officially commissioned to promote the envisaged measures". The target is the "actor necessary to realise (the measures)", such as citizens or companies (Owens \& Bressers, 2013).

Figure 3.1 is a schematic of how the interaction process occurs between actors. Various combinations of actor characteristics help describe the process of interaction between actors. This paper will assess how the regional and local levels of lowering GHG relate to the core characteristics defined in the red box where the dynamic process of actor interaction takes place. 
Knowing the core characteristics of the actors allows prediction and/or explanation of interaction processes in the implementation of certain projects (Bressers \& de Boer, 2013).

\subsection{Methods}

This study examines the transport sector and air pollution control in Bandung City and considers how the air quality improvement policies contribute to climate change mitigation. To address the main research question, case studies were broken down into two consecutive phases. The first phase is descriptive of actors' perspectives on local issues and programmes, especially air quality programmes and the contribution of these to climate change mitigation. The results are inputs into the second phase to help assess programmes for their effectiveness when based on the actors' estimation, interaction processes of actors, and other governance factors. The selection of actors considers their objectives and responsibilities, and their perception of the other actors. All local level actors were chosen from the same region using a theoretical framework of which actors would be best.

\subsubsection{Data Collection: Interview and Secondary Data}

Data were gathered from a variety of sources. Primary data was gathered from the three levels of government using fieldworkers, namely: national, provincial and local levels, all in the same region. The targeted departments from these levels of government included: the development planning agency, transport department, environment and forestry, land use planning, and public transport. Secondary data comprised documents (policies and programmes). Documents used included: climate change mitigation action plan, a midterm plan, a strategic plan, a working plan, a performance accountability report and a technical report on the current environmental status and the transport sector. Official statistics were used as much as possible. Data sources were triangulated to check for consistency. Where inconsistencies existed, estimates provided by knowledgeable local officials were used.

\subsubsection{Data Analysis and Results}

Data were analysed by use of Atlas.ti software by highlighting responses in each section of interest to build a narrative. Data were interpreted and grouped using CIT (e.g. the concept of actor characteristics of motivation, cognitions and resources). Using the Atlas.ti software simplified data analysis, especially in coding actor interpretations and perceptions of the programmes. An example of such coding can be found in Section 4.2.4, where it is used to capture the Mayor's motivations in the policy implementation process.

\subsubsection{General Introduction to the Bandung Case Study}

Bandung City is the capital of West Java (see figure 3.2). It is the most densely populated province in Indonesia. Nowadays, it has become a metropolitan area called the Greater Bandung Metropolitan Area (BMA). Bandung is a core city of metropolitan areas surrounded by suburban areas that are municipalities (Bandung, West Bandung, Sumedang, Indonesia) and Cimahi City. The intensity of daily commuting to and from the hinterland of the four cities to core cities varies 
between morning and night. In 2010, Bandung's population reached 2.5 million at night and 3 million people during the day (BPLH, 2013). In 2012, the total trips in the Greater Bandung Metropolitan area reached 3.57 million people per day and was expected to rise by $60 \%$ by 2020 (5.57 million people/day) (Pemprov Jawa Barat, 2013).

Transportation problems in Bandung City appear when the capacity of the transportation infrastructure is unable to meet increasing travel demand. In 2009, there were 32 primary traffic congestion locations in Bandung City. These were caused by economic activities (e.g., street vendors, market places, paratransit - a minibus that has small capacity) and increased use of motorised transport (see Table 3.1). However, in 2013, the traffic congestion scattered across 44 locations (Bappeda, 2013).

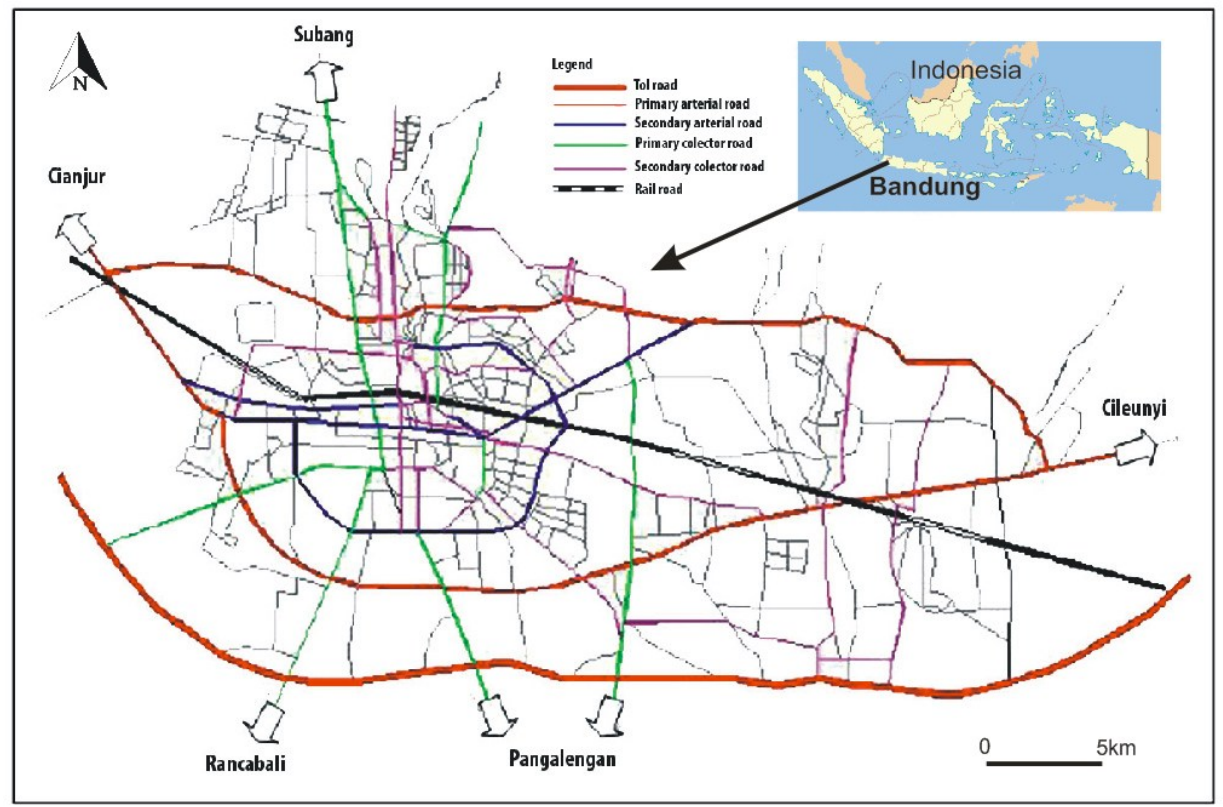

Figure 3.2: Greater Bandung Metropolitan Area 2017.

Source: adapted from Pemprov Jawa Barat (2013)

Table 3.1: The number of public and private vehicles based on type in Bandung City. Source : Data from BPS Kota Bandung (2013)

\begin{tabular}{ccc}
\hline No. & Type of & Quantity \\
\hline 1 & Private motorcycle & $1,030,729$ \\
2 & Private car & 318,598 \\
3 & Public bus transport & 3,166 \\
\hline
\end{tabular}




\begin{tabular}{ccc}
\hline 4 & Non-public bus & 2,181 \\
5 & Taxi & 1,856 \\
6 & Paratransit (angkot) & 5,521 \\
& Total & $1,362,051$ \\
\hline
\end{tabular}

Currently, $80 \%$ of the local road network capacity in Greater Bandung has reached saturation. The main public transport in core cities still relies on the paratransit and buses with limited routes and limited quantities, such as Bus Rapid Transit (BRT). Rail-based public transport serves only a small part of the travel demand (i.e. on the east - west path) and do not have the capacity to meet the increasing traffic demand. There are three main impacts of transportation in Bandung City (see Table 3.2).

Table 3.2: Impact of transportation in Bandung City. Sources: Stakeholder analysis, Data from (Bappeda, 2013; BPLH, 2013)

\begin{tabular}{|c|c|c|}
\hline Economic impact & Environmental impact & Social impact \\
\hline $\begin{array}{l}\text { - } \quad \text { Transportation costs in } \\
\text { Bandung city US\$33.5 / } \\
\text { month or equal to } 22 \% \text { of } \\
\text { gross-expenditure (ideally } \\
\text { no more than 20\%) } \\
\text { - Total cost of transportation } \\
\text { in Greater Bandung (2013) } \\
\text { equal to US\$1.42 billion / } \\
\text { year (equal to } 10.3 \% \\
\text { regional gross domestic } \\
\text { product) and ideally no } \\
\text { more than } 7 \%\end{array}$ & 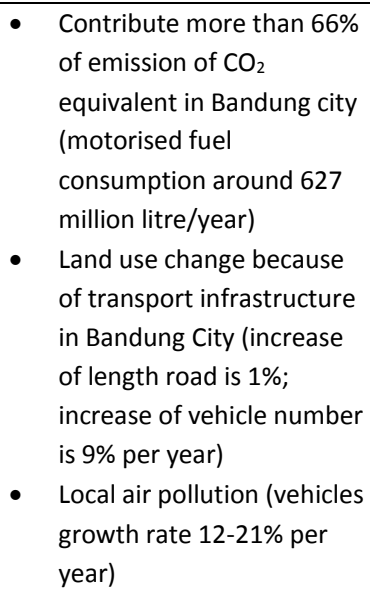 & $\begin{array}{l}\text { - } \\
\text { increase } 22 \% \text { per year } \\
\text { - } \quad \text { Effect of congestion on } \\
\text { physical and mental health } \\
\text { increase (cannot be } \\
\text { measured by local } \\
\text { government) }\end{array}$ \\
\hline
\end{tabular}

Greater Bandung Metropolitan Area (BMA) has become a priority for the regional government (West Java Provincial). The focus is to manage the areas between Bandung city and surrounding cities, as mentioned in Governor Decree no. 70 year 2013. Managing Greater BMA is important, not only for its economic development, but also for its transportation network and infrastructure. There are three classes of GHG emissions in Bandung City (see Figure 3.3). The energy and transport sectors are responsible for most emissions, particularly in the sub-sector of road transportation. 


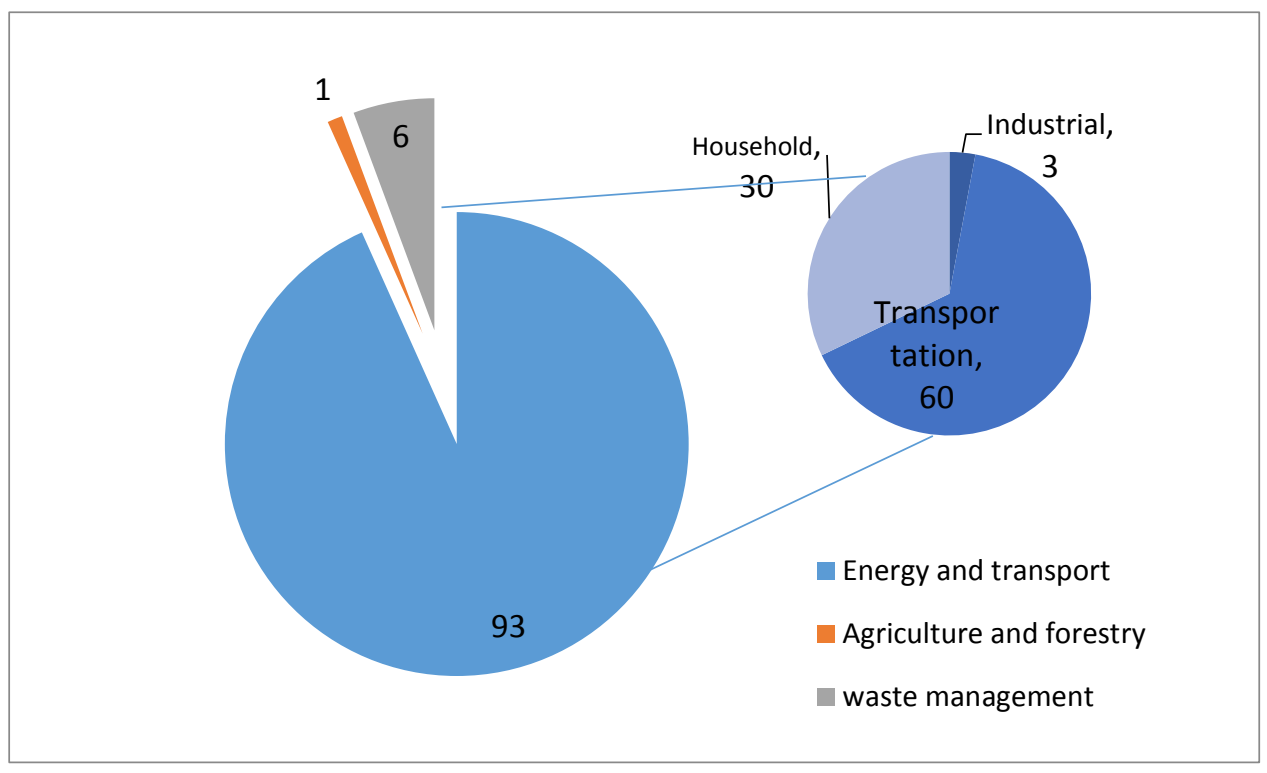

Figure 3.3: GHG emissions by sector in Bandung City 2013.

Source: Adapted from BPLH, 2013

From guidance to lower GHG emissions, as published by Bandung Environmental Management Agency (EMA), the strategies in the transport sector will also contribute to the reduction of air pollution. The strategies are: (1) to avoid or reduce the number of trips that are not directly necessary; (2) to shift to other environmentally friendly vehicles or forms of non-motorised transportation; and (3) and to improve efficiency of vehicles by improving vehicle technologies.

\subsubsection{Chronology of Mitigation Events and Assessment of Core Characteristics of Bandung City Actors}

This section presents the chronology of key events in climate change mitigation policy making in Bandung City. In Indonesia, the climate change mitigation effort, based on the National Action Plan on reducing GHG (RAN-GRK), as mentioned in the Presidential Decree no. 61 Year 2011, shows that the forestry sector and the peatland sector are the main sectors targeted for GHG emissions reduction ( $88.6 \%$ or equivalent to 0.672 Giga ton $\mathrm{CO} 2 \mathrm{e}$ ) followed by waste management $(6 \%)$, energy and transport $(5 \%)$, agricultural $(1 \%)$ and industry $(0.13 \%)$. Although energy and transport come in third place, urban areas are the largest contributor of GHGs emission, especially in Java (Bappenas, 2011). This indicates increasing GHG emissions in the transport sector as a major source in Bandung City $(60 \%$ or $1394.98 \mathrm{Gg} \mathrm{CO} 2$ equivalent from road transport). Transport is also the sector contributing the most to air pollution $(60 \%-88 \%)$, particularly from the intensive use of motor vehicles (BPLH, 2013). The air quality from roadside monitoring shows an annual increase (by 4-8 times) in the concentrations of hydrocarbon, PM10 and CO (in particular PM10 exceeded the WHO standard) (BPLH, 2014). 
After the Conference of Parties (COP) 15 in the Copenhagen Accord and G-20 Pittsburgh assembly, the Government of Indonesia (Gol) committed to reducing GHG emissions. This commitment is driven by top-down, rather than bottom-up, strategies. Implementation challenges in developing countries that lack effective central regulatory regimes and plentiful budgets need the help of bottom-up analysts (Halsnaes \& Shukla, 2008; Thambiran \& Diab, 2011b).

Three years after COP 15, the Gol developed a National Appropriate Mitigation Action (NAMA). This aimed to implement actions below the national level. However, reducing GHG emissions from the transport sector, not only carried on by the central government, but also by designing and implementing a focus at local levels (Situmeang et al., 2012). The NAMA development process in Indonesia also predominantly followed a top-down approach. The NAMA guidelines came from National Development Planning Agency (BAPENNAS). This is embedded in national government policies, both mid-term and long-term. Provincial level governments were not involved in drafting the National GHG reduction plan (RAN-GRK). However, they were involved at a later stage when RAN-GRK was finished. Provincial level governments developed their own GHG reduction plans (Jaeger et al., 2015). Moreover, the provincial plans also became a guide for local level governments to mitigate climate change in the transport sector. In West Java, the provincial government compiled guidelines for achieving the regional GHG reduction plan that stipulated on Governor Decree No. 56 Year 2012 about RAD-GRK 2012 -2020. It contains the baseline of GHG emissions, general descriptions of the emitters, as well as mitigation actions and suggestions on how to measure GHG emissions.

However, the provincial level government assumed that GHG reduction activities would be conducted at the local level of Bandung City. The provincial level and local levels hold different perspectives on the implementation of policy instruments (see Table 3.2) to lower GHG emissions. From the interviews with the stakeholders at the local level, it appears that no particular programme for mitigation exists. The ongoing programmes were acknowledged, as are environment and transport programmes. Nonetheless, the Transportation Department states that several programmes could potentially contribute to lowering GHG emissions (e.g., by CFD, traffic management, non-motorised transport, parking management, intelligent transport systems, and by monitoring of urban air quality). These findings may be an opportunity to promote climate change as a means to address local problems, as well as to mitigate climate change (Bulkeley, 2003; Bulkeley, Castán Broto, \& Maassen, 2014).

It is also known that, although supplemented by various guidelines from the national, regional and local levels, evidence of lowering GHG emissions in the transport sector is not visible. This is evident from annual local action plans in the transport department and EMA. These lacked any action for mitigating climate change. This conclusion was also reinforced by the results of interviews with the local planning agency (Bappeda). This means that lowering GHG at the local level was not a top priority for local government compared to addressing local problems, such as traffic congestion, water pollution and waste reduction. These appear as a more serious challenge in Bandung. This situation does depend on actor motives and their cognition being 
gathering in the consensus development plan. The consensus of development plan (musrenbang) is a mechanism dialogue between the parties (stakeholders) related to direct and indirect benefits as a participatory approach to local development planning. Other reasons come from the local government perception of climate change. This is seen as simply a subset of a wider range of natural disasters, hazard risks, and domestic political pressures that undermine the international commitments to lowering GHG emissions in Indonesia (Gunningham, 2013).

However, an interesting approach came from the Mayor of Bandung. He has prioritised the development of thematic gardens to solving severe existing environmental problems (congestion, street vendors, waste, flood and transportation) ever since he was first elected. The aim of the Mayor's policy is to increase the citizens' level of happiness first, and then fix climate change problems later in a gradual manner. Beside the thematic garden, the Mayor also developed thematic days. These have become routine activities for Bandung citizens. The contributions to climate change mitigation include: (1) bus rides to schools every Monday; (2) cycling on Fridays and; (3) a Car-Free Day (CFD) on Sundays. There are three programmes related to climate change mitigation (bus schools, cycling, and CFD). The Institute for Global Environmental Strategies (IGES) has initiated the workshop for stakeholders in Bandung in 2015 regarding the co-benefits of transport sectors. This workshop aimed to realise sustainable urban transport in Bandung City (Nugroho, 2016).

This form of leadership is one of four drivers for climate change policy and action by local government (as also mentioned by Bulkeley et al., (2009)). Leadership attracts other organisations to participate in climate policy. It shows that individual political 'champions' have an important role to play in supporting progressive initiatives. This could help obtaining access to external funding that has been implemented in Bandung City in several programmes (bike rental spots and Bandros (tourist bus)), which comes from Corporate Social Responsibility (CSR) funding.

The actors have estimated the contribution of the existing programme to climate change mitigation. Some local government still needed to acknowledge the programmes that contribute to GHG emissions reduction from its activities, even though EMA already had found difficulties in gathering the emission data from all sectors. In line with the national target, local levels have to decrease their emissions by $2 \%$ per year. However, measuring emission levels to obtain primary data proves to be very difficult. Until now, the process of auction for collecting the emissions data is failing because no one is capable of carrying it out (do not meet the technical requirement).

Actors' understanding about the mitigation context also came from their knowledge of other actors involved in reducing GHG emissions. The Environmental Management Agency, which is in charge of the air quality improvement programme at the provincial and local levels, already knew that the transportation department had the most important role and authority to mitigate climate change and lower GHG emissions.

There are nine programmes or policies that relate to the lowering of GHG emissions in the transport sector at the local and provincial levels (see also Table 3.3). The strategy is based on 
the so-called 'avoid-shift-improve' paradigm. This is a framework for climate change mitigation of sustainable urban mobility that is generally used by GIZ and IGES (IGES, 2011).

However, GHG emissions monitoring does not support the existing policies. This practice is not in line with UNFCCC guidelines. These state "the effects of climate change mitigation actions should be documented in accordance with best methodologies and practices (fixed by multinational bodies, such as UNFCCC), and must be tractable and comparable in transparent ways (Buendia, Schmitz, Munzinger, Laksmi, \& Hanik, 2012)". Firstly, in Bandung City, the existing measure aims at ensuring that emissions inventories are updated periodically (based on Presidential Decree no. 71 year 2011). Secondly, the measurement activity is to report the achievement in reducing GHG emissions based on potential GHG emissions from various sectors.

Therefore, the relevant municipal competencies and availabilities for taking emission measurements in Bandung City need more attention. The authorities for collecting data in the transport sector are not clearly defined. The Local Transportation Department assumed that it was not their duty to measure GHG emissions. Therefore, they face difficulties in measuring the emissions from their programme (public transport). However, other local governments (EMA) conducted the emission inventory, but not necessarily for GHG emissions. 
Table 3.3: Particular policies that could contribute to lowering GHG emissions

\begin{tabular}{|c|c|c|c|c|c|c|c|}
\hline No & Policies & Budget or Finance & $\begin{array}{l}\text { Original purpose and Co- } \\
\text { benefits }\end{array}$ & Implementer \& Legal Basis & Target Group & Strategy & $\begin{array}{c}\text { Level of } \\
\text { Importance* }\end{array}$ \\
\hline 1 & $\begin{array}{l}\text { Paratransit } \\
\text { (minibus with } \\
12-14 \\
\text { passengers) }\end{array}$ & $\begin{array}{l}\text { Paratransit owners } \\
\text { Local level (vehicle } \\
\text { test) }\end{array}$ & $\begin{array}{l}\text { Meet the human need for } \\
\text { movement } \\
\text { Co-benefits: } \\
\text { 1. Increasing fuel } \\
\text { economic } \\
\text { 2. Reduce spending } \\
\text { 3. Unravel congestion }\end{array}$ & $\begin{array}{l}\text { Bandung Transportation Department } \\
\text { Legal basis: } \\
\text { SK Director General of Land No. } 687 \\
2002 \text { Technical Guidelines on the } \\
\text { Implementation Public Transport in } \\
\text { the Region Urban in Fixed Route and } \\
\text { Organised }\end{array}$ & $\begin{array}{l}\text { Passenger } \\
\text { Car \& } \\
\text { motorcycle } \\
\text { owner }\end{array}$ & Shift & +++ \\
\hline 2 & $\begin{array}{l}\text { Car-free day } \\
\text { (CFD) and Car- } \\
\text { free night (CFN) }\end{array}$ & $\begin{array}{l}\text { Local level (tourism } \\
\text { and health activities; } \\
\text { janitor, security) } \\
\text { Central government, } \\
\text { provincial } \\
\text { government and } \\
\text { local level (cultural } \\
\text { heritage- Jl. Asia } \\
\text { Afrika) }\end{array}$ & $\begin{array}{ll}\text { Better air quality } & \\
& \text { Co-benefits } \\
\text { 1. Improved health } & \\
\text { 2. Enhancing local } & \\
\text { economic } & \\
\text { 3. Tourism attraction } \\
\text { 4. Dissemination of } \\
& \text { information }\end{array}$ & $\begin{array}{l}\text { Bandung Transportation Department; } \\
\text { Bandung Tourism Agency; Bandung } \\
\text { City Police } \\
\text { Legal basis: } \\
\text { - Mayor decree No. } 551 \text { / } \\
\text { Kep.449-Affair of } 2011 \text { on the } \\
\text { implementation of Car-Free } \\
\text { Days in Bandung } \\
\text { Mayor Regulation No. } 888 \text { of } \\
2010 \text { on Management and } \\
\text { Development Street Vendors }\end{array}$ & $\begin{array}{l}\text { Car users } \\
\text { Authorities } \\
\text { Families } \\
\text { Students } \\
\text { Street } \\
\text { vendors } \\
\text { Property } \\
\text { owners }\end{array}$ & $\begin{array}{l}\text { Avoid (Land use } \\
-\quad \text { behavioural } \\
\text { change) or Push } \\
\text { policy }\end{array}$ & +++ \\
\hline 3 & $\begin{array}{l}\text { Vehicle test } \\
\text { feasibility and }\end{array}$ & $\begin{array}{l}\text { Local level (vehicle } \\
\text { test with transport } \\
\text { department and } \\
\text { emission test with }\end{array}$ & $\begin{array}{l}\text { Safety driving and better air } \\
\text { quality } \\
\text { Co-benefits }\end{array}$ & $\begin{array}{l}\text { Bandung Transportation Department; } \\
\text { Bandung Environmental Management } \\
\text { Agency }\end{array}$ & Car users & Improve & +++ \\
\hline
\end{tabular}




\begin{tabular}{|c|c|c|c|c|c|c|c|}
\hline & $\begin{array}{l}\text { Emission test } \\
\text { (part of EKUP) }\end{array}$ & $\begin{array}{l}\text { environmental } \\
\text { management) }\end{array}$ & $\begin{array}{l}\text { 1. Increasing fuel } \\
\text { economic of vehicle } \\
\text { 2. Reducing future } \\
\text { operating costs }\end{array}$ & $\begin{array}{l}\text { Legal basis: } \\
\text { - Minister of Environment } \\
\text { Regulation No. } 5 \text { of } 2006 \text { on the } \\
\text { threshold of motor vehicle } \\
\text { exhaust emissions } \\
\text { Bandung Regional Regulation } \\
\text { No. } 11 \text { of } 2005 \text { on the } \\
\text { implementation of discipline, } \\
\text { cleanliness, and beauty }\end{array}$ & & & \\
\hline 4 & $\begin{array}{l}\text { Trans Metro } \\
\text { Bandung (TMB) } \\
\text { and School bus }\end{array}$ & $\begin{array}{l}\text { Local level (shelters } \\
\text { and buses) } \\
\text { Central government } \\
\text { (Buses provision for } \\
\text { TMB) }\end{array}$ & $\begin{array}{l}\text { Improve occupancy rates and } \\
\text { Improve using of public } \\
\text { transportation } \\
\text { Co-benefits: } \\
\text { 1. Reduce spending } \\
\text { money } \\
\text { 2. Unravel congestion } \\
\text { 3. Increasing fuel } \\
\text { economic }\end{array}$ & $\begin{array}{l}\text { Bandung Transportation Department } \\
\text { Legal basis: } \\
\text { - } \text { Bandung Mayor Decision No. } \\
551 \text { / Kep.764-Transportation / } \\
2012 \text { on Operation Trans Metro } \\
\text { Bandung In Corridor } 2 \\
\text { Cicaheum-Cibereum } \\
\text { Bandung } \\
\text { Bandung Mayor's decision } \\
\text { number 551.2 / } 694- \\
\text { Transportation Kep / } 2008 \text { on } \\
\text { the tariff mass transit bus Trans } \\
\text { Metro Bandung } \\
\text { Bandung Mayor Regulation No. } \\
704 \text { of 2008 on Minimum } \\
\text { Service Standards (MSS) } \\
\text { operation of TMB }\end{array}$ & $\begin{array}{l}\text { Passenger } \\
\text { Authorities } \\
\text { Car \& } \\
\text { motorcycle } \\
\text { owner }\end{array}$ & $\begin{array}{l}\text { Shift (usage } \\
\text { larger unit) }\end{array}$ & +++ \\
\hline 5 & $\begin{array}{l}\text { Cycling policy as } \\
\text { part of } \\
\text { 'Thematic day'; }\end{array}$ & 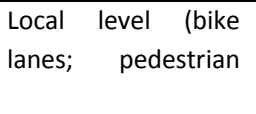 & $\begin{array}{ll}\text { 1. } & \text { Better air quality } \\
\text { 2. } & \text { Health improvement }\end{array}$ & $\begin{array}{l}\text { Bandung Environmental Management } \\
\text { Agency; Bandung Spatial and Public }\end{array}$ & $\begin{array}{l}\text { - Car users } \\
\text { - Employee }\end{array}$ & Shift & ++ \\
\hline
\end{tabular}




\begin{tabular}{|c|c|c|c|c|c|c|c|}
\hline & $\begin{array}{l}\text { Pedestrian walk } \\
\text { lane and Bike } \\
\text { Park } \\
\text { (infrastructure) }\end{array}$ & $\begin{array}{l}\text { walk lane, bike } \\
\text { shelters) }\end{array}$ & $\begin{array}{l}\text { Co benefits: } \\
\text { 1. Lowering cost } \\
\text { 2. Unravel traffic } \\
\text { congestion }\end{array}$ & $\begin{array}{l}\text { works agency; Department Youth and } \\
\text { Sport } \\
\text { Legal Basis: } \\
\text { - Bandung Regional Regulation } \\
\text { No. 16/2012 on the } \\
\text { Implementation of } \\
\text { Transportation and Retribution } \\
\text { in the Field Transportation } \\
\text { (article } 12 \text { and 32) }\end{array}$ & & $\begin{array}{l}\text { (Pull policy) as } \\
\text { Non-motorized } \\
\text { transport (NMT) }\end{array}$ & \\
\hline 6 & $\begin{array}{l}\text { Four in one } \\
\text { (every } \\
\text { Saturday) }\end{array}$ & $\begin{array}{l}\text { Local level (traffic } \\
\text { sign) }\end{array}$ & $\begin{array}{l}\text { Reduce traffic loading in } \\
\text { particular area (four } \\
\text { passengers for one car) } \\
\text { Co benefits: } \\
\text { 1. Reduce VCR in specific } \\
\text { road } \\
\text { 2. Unravel congestion }\end{array}$ & $\begin{array}{l}\text { Bandung Transportation Department; } \\
\text { Bandung City Police } \\
\text { Legal basis: } \\
\text { - Mayor decree No.551/Kep.582- } \\
\text { Dishub/2013 regarding } \\
\text { Stipulation of Zone Traffic } \\
\text { Control and Liability } \\
\text { Transporting at least } 4 \text { People } \\
\text { Passenger Vehicle for } \\
\text { Individuals At the Roads Specific } \\
\text { in Bandung }\end{array}$ & - Car users & $\begin{array}{ll}\text { Avoid } & \text { (push } \\
\text { policy) } & \end{array}$ & ++ \\
\hline 7 & $\begin{array}{l}\text { Management } \\
\text { and traffic } \\
\text { engineering } \\
\text { (including } \\
\text { parking control) }\end{array}$ & $\begin{array}{l}\text { Local level (traffic } \\
\text { sign and operator) }\end{array}$ & $\begin{array}{l}\text { Reduce congestion and } \\
\text { changes traffic light (led light) } \\
\text { also intensification activities } \\
\text { in the framework of Parking } \\
\text { Control } \\
\text { Co-benefits: } \\
\text { 1. Reduce cost and } \\
\text { maintenance }\end{array}$ & $\begin{array}{l}\text { Bandung Transportation Department } \\
\text { Legal basis: } \\
\text { Bandung Regional Regulation } \\
\text { No. } 11 \text { of } 2005 \text { on the } \\
\text { implementation of discipline, } \\
\text { cleanliness, and beauty } \\
\text { Mayor's decision No. } 551 \text { / Kep. } \\
\text { 737-Transportation / } 2012\end{array}$ & $\begin{array}{l}\text {-Car users } \\
\text {-motorcycle } \\
\text { users }\end{array}$ & Avoid & + \\
\hline
\end{tabular}




\begin{tabular}{|c|c|c|c|c|c|c|c|}
\hline 8 & $\begin{array}{l}\text { Progressive tax } \\
\text { on pollution }\end{array}$ & $\begin{array}{lr}\text { Provincial } & \text { Level } \\
\text { (Local Revenue } \\
\text { Department of West } \\
\text { Java) }\end{array}$ & $\begin{array}{l}\text { Reduce vehicle ownership } \\
\text { Co-benefits: } \\
\text { 1. Increasing the income }\end{array}$ & $\begin{array}{l}\text { Local Revenue Department of West } \\
\text { Java } \\
\text { Legal basis: } \\
\text { - West Java Provincial Regulation } \\
13 \text { in } 2011 \text { on Local Taxes } \\
\text { - West Java Governor Regulation } \\
\text { No. } 33 / 2013 \text { on Guidelines for } \\
\text { the Implementation of the West } \\
\text { Java Provincial Regulation No.13 } \\
\text { of } 2011\end{array}$ & Cars owner & $\begin{array}{l}\text { Pricing or Push } \\
\text { policy }\end{array}$ & + \\
\hline 9 & $\begin{array}{l}\text { Proklim } \\
\text { (climate village } \\
\text { program) }\end{array}$ & $\begin{array}{l}\text { Provincial level } \\
\text { (central level from } \\
\text { de-concentration) }\end{array}$ & $\begin{array}{l}\text { Promote adaptation and } \\
\text { mitigation action and give } \\
\text { appreciation from central } \\
\text { government to local level } \\
\text { Other co-benefits: } \\
\text { 1. Intensified action in } \\
\text { local level } \\
\text { 2. Documentation of } \\
\text { mitigation and } \\
\text { adaptation action }\end{array}$ & $\begin{array}{l}\text { West Java EMA } \\
\text { Legal Basis: } \\
\text { Ministry Environment Decree No. } \\
19 / 2012 \text { regarding Climate Village } \\
\text { Programme (Programme Kampung } \\
\text { Iklim) }\end{array}$ & $\begin{array}{l}\text { Village } \\
\text { communities }\end{array}$ & Pull policy & + \\
\hline
\end{tabular}

*Plus sign informs the intensity of importance of the policies (based on actor's perspectives and analysis); Source: Collected data and interview analysis 


\subsubsection{Overview of Key Stakeholders}

The empirical study shows that the involvement of actors related with climate change mitigation in Bandung City depends on their interest in the issue and their power basis. Only a few actors in the transport sector context have high interest (Ministry of Transportation, Local Transport Department and Local EMA). Collaboration only existed in national and provincial levels, as mentioned in the aims of RAN-GRK. Even at the local levels, some implemented their initial target of GHG reduction. Local governments can decide themselves to determine the activities according to their specific abilities and particular conditions. Table 3.4 presents an overview of the key stakeholders.

Table 3.4: Stakeholders of climate change mitigation and air quality improvement in the transportation sector (Bandung City). Sources: Data collecting and interview analysis

\begin{tabular}{|c|c|c|c|c|}
\hline \multirow[t]{2}{*}{ Stakeholders } & \multicolumn{4}{|c|}{ Key characteristics } \\
\hline & Involvement in the issue & $\begin{array}{l}\text { Interest in } \\
\text { the issue }\end{array}$ & $\begin{array}{c}\text { Influence / } \\
\text { power }\end{array}$ & Position \\
\hline $\begin{array}{l}\text { Ministry of the } \\
\text { Environment and } \\
\text { Forestry }\end{array}$ & $\begin{array}{l}\text { Guidance for Inventory GHG in } \\
\text { national level (MRV) \& Guidance for } \\
\text { Air quality improvement }\end{array}$ & $\begin{array}{l}\text { Medium - } \\
\text { High }\end{array}$ & Medium & Supportive \\
\hline $\begin{array}{l}\text { Ministry of } \\
\text { Transportation }\end{array}$ & $\begin{array}{l}\text { Guidance for transportation sector } \\
\text { project and policies }\end{array}$ & $\begin{array}{l}\text { Medium - } \\
\text { High }\end{array}$ & High & Supportive \\
\hline $\begin{array}{l}\text { Ministry of Public } \\
\text { works }\end{array}$ & $\begin{array}{l}\text { Responsible for providing large } \\
\text { public infrastructure (including } \\
\text { finance) }\end{array}$ & Medium & $\begin{array}{l}\text { Medium- } \\
\text { High }\end{array}$ & Supportive \\
\hline $\begin{array}{l}\text { National Planning } \\
\text { board }\end{array}$ & $\begin{array}{l}\text { Provides a guideline for } \\
\text { implementing GHG emissions } \\
\text { reduction plan \& Indonesian climate } \\
\text { change sectoral roadmap (ICCSR), } \\
\text { strengthening the ministry in } \\
\text { developing SUTRI NAMA } \\
\text { (sustainable urban transport) }\end{array}$ & $\begin{array}{l}\text { Medium - } \\
\text { High }\end{array}$ & High & Supportive \\
\hline $\begin{array}{l}\text { Environmental } \\
\text { Management } \\
\text { agency of West } \\
\text { Java }\end{array}$ & $\begin{array}{l}\text { Collecting inventory emission for } \\
\text { regional \& provide guidelines, } \\
\text { environmental programme }\end{array}$ & Medium & Medium & Supportive \\
\hline $\begin{array}{l}\text { Transportation } \\
\text { Department of } \\
\text { West Java }\end{array}$ & $\begin{array}{l}\text { Responsible for policy of transport } \\
\text { sector in regional area }\end{array}$ & $\begin{array}{l}\text { Low- } \\
\text { Medium }\end{array}$ & Medium & Supportive \\
\hline $\begin{array}{l}\text { Bandung Planning } \\
\text { Agency }\end{array}$ & $\begin{array}{l}\text { Coordinates GHG reduction policies } \\
\text { to local medium-term work plan }\end{array}$ & Medium & High & Supportive \\
\hline $\begin{array}{c}\text { Bandung } \\
\text { Department of }\end{array}$ & $\begin{array}{l}\text { Makes infrastructure for pedestrians } \\
\text { and highways }\end{array}$ & $\begin{array}{l}\text { Low- } \\
\text { Medium }\end{array}$ & $\begin{array}{l}\text { Medium- } \\
\text { High }\end{array}$ & Supportive \\
\hline
\end{tabular}




\begin{tabular}{|c|c|c|c|c|}
\hline $\begin{array}{l}\text { Highways and } \\
\text { Irrigation }\end{array}$ & & & & \\
\hline $\begin{array}{c}\text { Bandung } \\
\text { Environmental } \\
\text { Management } \\
\text { Agency }\end{array}$ & $\begin{array}{l}\text { Collecting GHG emissions data and } \\
\text { report; mitigation and adaptation } \\
\text { activities in general and in terms of } \\
\text { air quality; makes climate change } \\
\text { guidelines }\end{array}$ & $\begin{array}{l}\text { Medium- } \\
\text { High }\end{array}$ & $\begin{array}{l}\text { Medium- } \\
\text { High }\end{array}$ & Supportive \\
\hline $\begin{array}{c}\text { Bandung } \\
\text { Department of } \\
\text { Transportation }\end{array}$ & $\begin{array}{l}\text { Provide urban transport (public bus } \\
\text { transport) and infrastructure as well } \\
\text { as licensing }\end{array}$ & $\begin{array}{l}\text { Medium- } \\
\text { High }\end{array}$ & High & Supportive \\
\hline $\begin{array}{l}\text { Private sector } \\
\text { (bus operator, } \\
\text { state owned } \\
\text { enterprise) }\end{array}$ & $\begin{array}{l}\text { Provide urban transport (including } \\
\text { funding for infrastructure) }\end{array}$ & Low & High & Supportive \\
\hline $\begin{array}{l}\text { Paratransit owner } \\
\text { (cooperation) }\end{array}$ & $\begin{array}{l}\text { Owner and operate minibus for } \\
\text { public transportation (may conflict } \\
\text { with others providers) }\end{array}$ & Low & $\begin{array}{l}\text { Medium- } \\
\text { high }\end{array}$ & Opposed \\
\hline $\begin{array}{c}\text { Networking } \\
\text { expert }\end{array}$ & $\begin{array}{l}\text { Provides assessment of sustainable } \\
\text { urban transport }\end{array}$ & $\begin{array}{l}\text { Medium- } \\
\text { High }\end{array}$ & Medium & Supportive \\
\hline Asbekindo & $\begin{array}{l}\text { Indonesian vehicle maintenance } \\
\text { association was appointed as an } \\
\text { emission test operator and } \\
\text { improving engine performance }\end{array}$ & $\begin{array}{l}\text { Medium- } \\
\text { High }\end{array}$ & Medium & Supportive \\
\hline
\end{tabular}

\subsubsection{Results of the Actor Interactions Analysis}

The climate change mitigation already conducted at the local level was more focused on solid waste management and tree planting (greening). The local environmental management agency (EMA) acknowledged that their institution had to collect GHG emissions data in Bandung City, as required by central government. All stakeholders assumed that the greatest responsibility for mitigation lay with the local transport department. The dynamic actor interaction of local government actors can be seen in Figure 3.4. 


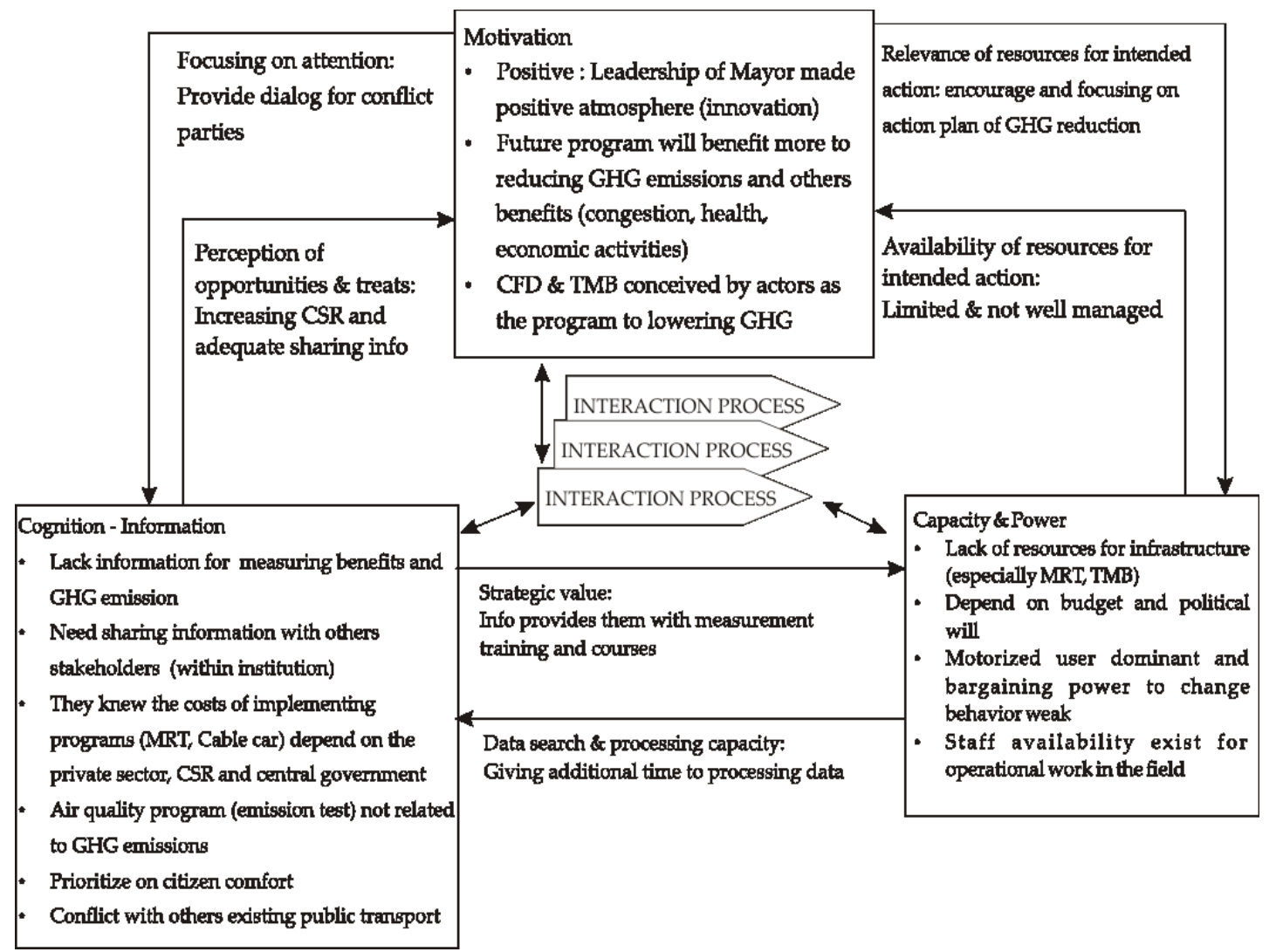

Figure 3.4: The dynamic actor-characteristic's interaction of local-level actors (implementers). Source: The scheme is used with permission from Bressers (2009); Zooming in on the 'Process' in Figure 1

The local transport department encourages the Car-Free Day (CFD) and TMB to lower GHGs emission. However, they lack adequate information and knowledge on how these policies and the resulting reductions could be measured. They prioritise citizen comfort and reducing conflict between public transport modes (improvement public transport), rather than action to achieve climate change mitigation goals. The local transport department was aware that implementing other programmes (such as those already in planning, such as MRT and cable cars) required resources that could not be afforded at the local level. However, all actors at the local levels agreed that the leadership of Bandung Mayor created a positive atmosphere in providing public services in Bandung City. 
It is also evident that the local level actors believe that the Mayor has the capability to influence other stakeholders, not only in Indonesia, but also from other countries interested in investing in Bandung City. There have been several flagship programmes launched by the Mayor; some of which relate to reducing GHG emissions. The school bus programmes, bicycle policies and public transport use are programmes to deal with climate change mitigation. However, challenges, such as lack of resources for infrastructure, depend on available budgets (especially from the central government). These issues have made it difficult to implement this policy. This has led to problems, such as the dominance of motorised users in Bandung City, and a lack of coordination with other regions and provinces.

Using the CIT to analyse motivations, cognitions and capacity and power as characteristics of local-level actors (see Figure 3.4) reveals how and why a policy is implemented in a certain manner. When analysed, the actor characteristics provide a way to understand where the actors are focusing, the opportunities available to them, as well as identifying the threats that may influence the result of the implementation process. In this case, as has been discussed above, incorporating air pollution control with climate policy at the local level has been met with challenges that include focusing attention to manage conflict between the different actors, rather than successfully promoting climate change mitigation. With regards to opportunities, the actors realised that funding through different avenues, especially CSR, could lead to successful policy implementation, but a lack of information (and knowledge), especially to measure the benefits of climate change mitigation, placed them at a disadvantage.

\subsection{Discussion}

Despite the lack of actors understanding about air quality improvement in the transport sector and their mutual co-benefits in lowering GHG emissions, a possibility to synergise the local programmes emerges from the local perspectives (municipality and provincial level). The paratransit, car-free day, vehicle emission test (validity test), and TMB (Bus Rapid Transit) have received more attention from the public and the government. However, the role of external actors (the central government) in encouraging and supporting the local level to create positive conditions is required to create a synergy with the national goals.

Central government has a strong desire to reduce the GHG emissions. However, the interest and the influence (power) to act separately among the actors, together with the lack of coordination and diverse perception of the issues, can complicate the achievement of national targets. These barriers are similar at the provincial and local levels.

Narrowing down to the local level, the positive motivations triggered by the leader of Bandung City, involving several flagship programmes that promote sustainability, have been well received by the community. However, in terms of air quality improvement and climate policy, the stakeholders shared the same concerns over a lack of information and guidance on how to synergise the programmes. The lack of information led to a conflict with the existing public transport. Political and financial support from the national government has been the most crucial 
aspect to incorporate air pollution control with climate policy at the local level. This constraint will not have much influence if the cognition and motivational aspects are still weak.

\subsection{Conclusions}

This study has provided a preliminary assessment as to how existing programmes could potentially address co-benefits. Besides air quality improvement, other benefits perceived by actors included health improvement, enhancing local economic, tourism attraction, and reducing congestion. Local actors' motivation to deploy climate policies was based on their local priorities. Local actors were aware of their lack of resources to develop the infrastructure for public transport and for local government to adapt their programmes in low-cost budgets. When addressing local problems, it will be necessary to ascertain and crosscheck the policies in the wider context.

The example of the transport sector in Bandung City has highlighted the difficulties faced by actors at different levels of government in trying to implement climate change mitigation policies, as expected by international policy makers.

Acknowledgement of the local perspectives in terms of air quality improvement and climate policy is expected to provide Bandung with a wide diversity of policy options. The identification of the effectiveness of the programmes, not only handled by the certain sectors, but also need the analysis of others actors, such as other implementers and target actors.

This chapter has shown how the transport sector policy has contributed to the emission of GHG emissions in Indonesia and, especially in the particular case of Bandung City. The political context has interfered with the development of road transport in Indonesia, especially in Java Island. The central government policy has influenced the management of public transport in local level, despite the decentralisation initiated.

In Bandung City, the private vehicles (motorcycle and cars) are dominantly used as transportation, more so than public transport, such as urban transport and bus. In terms of GHG emissions, as indicated by fuel consumption, the public transport has a better choice than private vehicles. This also confirms the sectoral data of GHG emissions that show the transport sector as having the highest percentage of emitting GHGs.

The descriptive study of climate change mitigation efforts, as perceived by actors, shows that policy instruments (see Table 3.3) are believed to influence the reduction of GHG emissions. The actors acknowledged that the level of importance of the policy instrument did not automatically mean a programme has a major influence, but only stated that, if the policy instrument conducted correctly, it can provide significant benefits.

The choice of the paratransit case study was based on their involvement in a public transport service that was trusted by the community. Even the development of TMB modes has not replaced the paratransit as the main public transport in Bandung City. It occupies almost $61 \%$ of 
the area in Bandung City. The level of trust remains high particularly for lower income community (Joewono \& Kubota, 2007; Tarigan et al., 2014).

Potential lowering of GHG emissions by paratransit, compared to other modes of transport, especially DAMRI or TMB, will definitely be lower when only counting the capacity (seater) mode only. However, the large number of operating vehicles (approximately 12,000 unit includes Greater Bandung Metropolitan Area) and their vehicle range reaching out to the remote areas means this paratransit mode should be considered as an option. The actors involved at local levels and the potential conflict that already existed became the object of interest for research.

Using actor characteristics, the mitigation programmes that can impact on climate change and co-benefits in the transport sector are: Paratransit, Car-Free Day, Vehicle validity test, and Trans Metro Bandung. To answer the question of how this programme could benefit from lowering GHG emissions will be explained further in chapter 4 that deals with the governance of climate change mitigation in Bandung City. Chapter 4 also will try to explain how the national action plan can align to the local level. The CIT of the paratransit will be described in more detail in chapter 5. 


\section{Chapter 4 Governance of Climate Change Mitigation in Bandung City}

\subsection{Introduction}

The issue of governance has emerged as an essential concept to the international community. In general, governance indicates the way a society sets and manages the rules that guide policymaking and policy implementation. When addressing the research question on how governmental actors of respective levels interact, the concept of multi-level governance acknowledges the importance of the coherence of vertical jurisdictions. However, how these urban politics of climate change translate to the local level as the most important decisionmakers in the policy network needs further study to assess their collaboration and their alignment.

The Bandung case was analysed by the Government Assessment Tools (GAT) that is based on the CIT framework (Bressers, 2004, 2009). As a framework, the CIT views the implementation processes as interaction processes that are driven by the main characteristics of the multiplicity of actors involved. Thus, the framework has the ability to "explain the course and results of the process from that simple starting point and to place these actors and their main characteristics central stage in any analytical model" (Bressers et al., 2016, p. 46).

The national climate change mitigation policy on the transport sector is implemented and translated via different perspectives at a local level. Knowing the characteristics of the multiple actors and multi-level stakeholders and their different backgrounds will increase understanding of governance in the climate change mitigation context. This governance is analysed according to the evaluation of various elements. The GAT defines governance as "the combination of the relevant multiplicity of responsibilities and resources, instrumental strategies, goals, actornetworks and scales that form a context that, to some degree, restricts and, to some degree, enables actions and interactions" (Bressers et al., 2013, p. 6).

To solve the climate change issue, the Indonesian government has promoted a national action plan to reduce greenhouse gas emissions (RAN-GRK). This RAN-GRK was aimed at increasing information access and guidelines for a regional action plan. At the local level and regional level, this RAN-GRK was translated into the regional action plans (RAD-GRK). However, in Bandung City, this RAD is only a strategic plan for climate change mitigation, particularly by the Local Environmental Management Agency (EMA). This chapter will unfold the general GAT was applied to the implementing actors (government) in Bandung City and at the regional levels (as an extension of the central government) and other stakeholders. The GAT includes the five dimensions (multi-level, multi-actor, multi-faceted, multi-instrument, and multi-resource based) of governance and evaluates them against the four semi-normative (Casiano \& de Boer, 2015, p. 4) qualities (extent, coherence, flexibility, and intensity) already discussed in Chapter 2. 


\subsection{Levels and Scales}

There are three levels involved in the governance of climate change mitigation in Indonesia. The central government (the first level) is engaged in the planning process and the creating of the strategic projects in Indonesia. The provincial government (the second level) is concerned with the action plan developed at their level through implementing the guidance distributed by the central government. Urban city policy (the third level) in Indonesia, as it relates to climate change, is guided by the Directorate of Urban and Rural (under the Ministry of National Development Planning/National Development Planning Agency - Bappenas). From the year 2014, Bappenas is under direct order of President Joko Widodo (Jokowi). The authorities of Bappenas not only establish and oversee the budget, but also directly facilitate development planning in every ministry, institution and government entities. This function creates cross-sector linkages. Bappenas has the authority to set-up the coordination team for RAN-GRK. The monitoring of RAN-GRK is in the arrangement of tasks of the Coordinating Ministry of Economic Affairs. At the national level, the implementation of RAN-GRK is governed further by the ministers/heads of the institutions, in accordance with the duties and authorities concerned.

The collaboration among levels associated with the monitoring and evaluation system appears to function within a top-down tiered approach. Bappenas conducted surveillance in a Middleterm plan at national level/regional level (RPJMN/D) and an Action plan (RKP/D). The Ministry of Internal Affairs performed the supervision of the local government. The Ministry of State Apparatus Reforms carried out the monitoring actions regarding the governmental accountability performance. The Ministry of Finance conducted the monitoring of the national budget.

As the responsibility following the ratification of climate change mitigation agreements, Government of Indonesia (Gol) has to report their actions. Periodic reports are conducted on forecast models. Indonesia had to set-up a database as a prerequisite. Other activities, such as the monitoring, reporting, and verifying ${ }^{20}$ (MRV) of mitigation action, have to be conducted at all levels. The programme of mitigation actions is executed at the local level.

The national level had encouraged the local level to reduce the GHG emissions. However, the local level actors are not aware that the programmes intend to mitigate the climate change. Another problem is that there is no clear measurement of GHG emissions from these mitigation efforts. For instance, the efficiency of Car-Free Day (CFD) programme was expected to reduce the GHG emissions, even though this activity appeared on the list of mitigation programmes (avoid strategy). A list of programmes to lower GHG emissions appears in the guidelines produced by the national level. However, there were programmes in Bandung that differed from the list of

\footnotetext{
${ }^{20} \mathrm{MRV}$ is a means to measure commitment and performance of emission reduction (domestic, internationally supported and credited NAMAs). In Indonesia, this MRV translated to "Pemantauan, Evaluasi, dan Pelaporan" (PEP) (Presidential Decree no. 71 Tahun 2011) even this PEP has different outcomes.
} 
national levels, such as developing pedestrian areas, reserving areas for pollution-free access, conducting vehicle emission tests, and encouraging public transport. The actions should adapt to the ability of each region.

Table 4.1: Overlay Mitigation Actions Based on Legal Basis of Multi-level governance in Transport Sector as Part of Energy and Transport (Bandung City). Source: Collected data and interview analysis

\begin{tabular}{|c|c|c|c|}
\hline & Central Government & West Java Province & Bandung City \\
\hline Action plan & $\begin{array}{l}\text { 1. Vehicle test (include } \\
\text { private cars and } \\
\text { motorcycle) (2010- } \\
\text { 2020) } \\
\text { 2. Application of } \\
\text { emission standard for } \\
\text { passenger new cars } \\
\text { (2010-2020) } \\
\text { Development of } \\
\text { modern system } \\
\text { logistic (2010-2020) } \\
\text { Development of car } \\
\text { labelling (2010-2020) } \\
\text { 5peed Limitation on } \\
\text { highways (2010- } \\
\text { 2014) } \\
\text { Vehicle tax based on } \\
\text { CO2 emission (2010- } \\
\text { 2014) } \\
\text { Tree plantation in } \\
\text { urban area (2010- } \\
\text { 2014) }\end{array}$ & 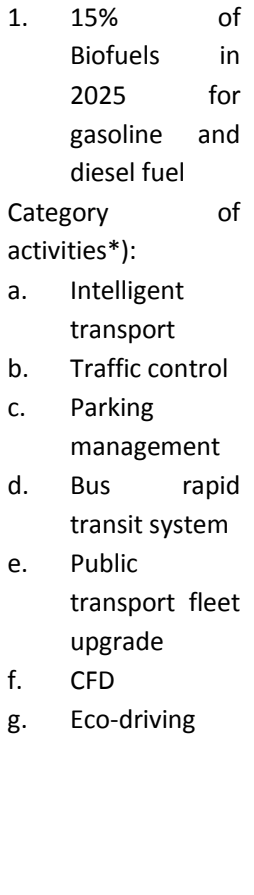 & 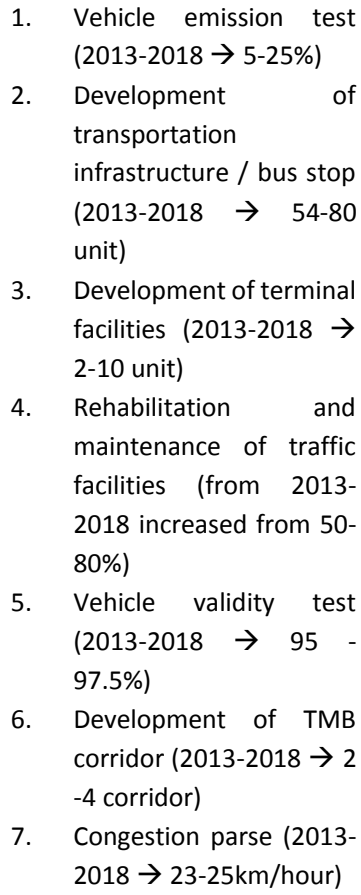 \\
\hline Legal & $\begin{array}{l}\text { Presidential Decree no. } \\
61 / 2011\end{array}$ & $\begin{array}{l}\text { Governor Decree } \\
\text { No. 56/2012 } \\
\text { *) based on regional } \\
\text { action plan } \\
\text { guidelines }\end{array}$ & $\begin{array}{l}\text { Bandung City Regulation No. } \\
3 / 2014\end{array}$ \\
\hline Responsibilities & $\begin{array}{l}1,2,3,4,5 \rightarrow \text { Ministry of } \\
\text { Transportation } \\
6 \rightarrow \text { Ministry of Finance } \\
7 \rightarrow \text { Ministry of Public works }\end{array}$ & $\begin{array}{l}\text { 1 } \rightarrow \text { Department of } \\
\text { Energy and Mineral } \\
\text { Resources (West } \\
\text { Java) } \\
\text { a-g } \rightarrow \text { Transportation } \\
\text { Department }\end{array}$ & $\begin{array}{l}1 \rightarrow \text { Bandung Environmental } \\
\text { management agency } \\
2-6 \rightarrow \text { Bandung Transport } \\
\text { Department }\end{array}$ \\
\hline $\begin{array}{l}\text { Target } \\
\text { Achievement }\end{array}$ & 0.038 Giga Ton $\mathrm{CO}_{2} \mathrm{e}$ & 1.1 million-ton $\mathrm{CO}_{2} \mathrm{e}$ & $\begin{array}{l}\mathrm{CO}_{2} \rightarrow 2127.06 \mathrm{Gg} \\
\mathrm{CH}_{4} \rightarrow 7.44 \mathrm{Gg} \\
\mathrm{N}_{2} \mathrm{O} \rightarrow 0.07 \mathrm{Gg}\end{array}$ \\
\hline
\end{tabular}




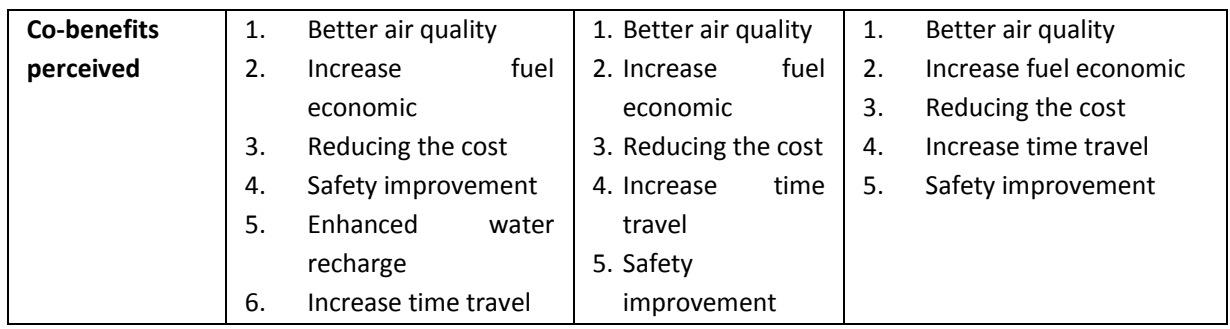

At the local level (see table 4.1), there are seven programmes that intended to reduce GHG emissions. Four programmes were categorised as involving infrastructure and facilities (bus provision, bus stops, traffic facilities, and terminals) and three as activities (vehicle emission test, validity test, and reduce congestion). However, from the actor's perspective (explained further on previous chapter 3 ) there are other activities in Bandung that have the possibility of lowering GHG emissions, such as paratransit and CFD.

The alignment of levels that stated as important in the guidelines (action plan) is complicated by the fact that, in reality, not all levels work together. For instance, the local level only received the type of buses provided by central government. The local level does not have the capability to choose a specification (such as a type of vehicle) that fits the conditions of Bandung City. The provincial level overlooked this.

From a multi-level governance viewpoint, all levels have some legal basis to respect climate change mitigation. At the central government, all actions planned in energy and transport sector are still segregated among the few governmental sectors, but are joined together in the RANGRK. The linkages and relationships of the RAN-GRK with the RAD-GRK are as follows: (1) RADGRK is part of RAN-GRK; yet the regional governments contribute according to their abilities and authorities, (2) RAD-GRK has to comply with RAN-GRK as far as their potential makes this possible and aligned to the priorities of each province. They can include different activities not yet regulated by the Presidential regulation no. 61/2011. This distinction is made to avoid double counting that can occur when national GHG emissions reduction calculations (measuring, reporting, verification or abbreviated MRV) consider all mitigation actions at both the national and the regional level.

In 2016, the Ministry of Environmental protection and Forestry launched the National Registry System (SRN-PPI) for climate change action. The objectives of SRN-PPI were to: organise the action, inform the climate change action, deliver the data and information to the citizen, and avoid the double counting ${ }^{21}$. This system has implemented the principle of "clarity, transparency,

${ }^{21}$ Can be accessed in http://ditjenppi.menlhk.go.id/srn/ 
and understanding" (CTU). However, prior to 2018, the mitigation actions, especially regarding the transport sector, were not recorded in the directory system.

The mitigation programmes were not rooted at the local level. The efforts were made by the central government and translated from their own resources and cognitions. The local level has to reformulate the programmes to make them feasible, based on their creativity and their limited resources. For instance, Car-Free Night (CFN) was a programme intended to limit private vehicles in a particular location on one occasion (one night). This programme was created at a local level to try to reduce GHG emissions and to generate co-benefits (tourism and economy creativity).

All government levels have a target to reduce the GHG emissions. The provincial and local levels have to make their own effort. The GHG emissions targeted for reduction are generally counted on the basis of instructions from the Tier $1^{22}$. The central government made the technical instruction on how to fill the inventory and suggested an action plan ${ }^{23}$. There was an issue concerning the technical aspect of the target as stipulated by central government. Some shifts and improved strategies were not included in this report, such as NMT and the vehicle emission test. There were some difficulties in counting the MRV of these programmes. However, in local government, these programmes (NMT and emission test) were already regularly applied.

Another issue concerning MRV came from the resources. There is a need for personnel, especially with a technical background to administer the survey (transportation), or emission tests, and to record data from daily activities. Staff also have many other tasks to fulfil. The local transport agency has limited personnel to control the public transport, to control the traffic and to regulate the result of the vehicle validity test and the costs of each trajectory. To include tasks that go beyond their main tasks requires adjustments. For instance, the main reason for the vehicle emission test was to order repair of the vehicles (engine) to meet the emission threshold. This issue will need an increased budget ceiling by local government. In this case, the local level has to deal with this within its limited own resources. There is a lack of information sharing between the monitoring agency (environmental department) and the transport sector department, especially in following-up on urban air quality, as well as its relation to the vehicle emission test results.

In general, the Local EMA conducts emission tests (vehicle emission monitoring and roadside monitoring) for air quality. The Provincial EMA monitors air quality and vehicle emission test within their budget (APBD) and through the de-concentration ${ }^{24}$ budget or co-administration ${ }^{25}$ (APBN) from the EKUP programme for the Bandung City. The Local Transport Department

\footnotetext{
${ }^{22}$ Overall GHG emissions inventory in Bandung City use the default value from IPCC guidelines 2006 if not stated from the Ministry of Environment and Forestry guideline (Kementerian Lingkungan Hidup, 2012)

${ }^{23}$ Can be accessed in http://ranradgrk.bappenas.go.id

${ }^{24}$ Delegation of authority and funding by the central to a region for discharge of a function not yet decentralized

${ }^{25}$ The co-administration or mede bewind is an arrangement whereby the central government coadministers not yet decentralized function with a local government and provides the requisite funding
} 
prepare public transport to take the test, assisted by the Indonesian Association of Vehicle Workshops of Regional West Java (Asbekindo). In 2011, Bandung City posted an Indonesian record after having conducted emission tests for 1,000 vehicles (both official and private cars) in one day. This action showed the best practice of the collaboration among the regional and local governments and of local level teamwork. The essence of the vehicle emission test was to keep the vehicle engine performance complying with the emission standard and to reduce air pollution.

However, paratransit owners thought that these test results were not well communicated ${ }^{26}$. The test was conducted for a particular public transport lane. Based on the paratransit owners' views, the test should suggest improvements for each vehicle to make them more fuel-efficient. The test should include an engine tune-up to improve the emissions based on criteria set by the government. Government stipulate public transport to conduct a vehicle inspection with a validity of six months. Private vehicle should do the same test once a year. The local transport department conducts the test. Later, however, this test became the concern of the 'Asbekindo Association' because the operator could manipulate ${ }^{27}$ the result, as the emission test results were recorded manually.

At the national level, several institutions deal with climate change mitigation with specific responsibilities and resources (see Table 4.2). However, political changes after elections meant all institutions have been integrated into the ministry. The National Board of Climate Change (DNPI) and Reducing Emissions from deforestation and forest degradation, plus other actions (REDD+), are integrated into the Ministry of Environment and Forestry (MOEF). However, the Ministry of National Development Planning/ BAPPENAS chaired the network of all sectors at the national level.

Table 4.2: Key institution elaborated in Indonesia's climate change response (mitigation). Source: collected data

\begin{tabular}{|l|l|l|l|l|}
\hline $\begin{array}{l}\text { Institution } \\
\text { aspect }\end{array}$ & $\begin{array}{l}\text { National } \\
\text { Development } \\
\text { Plan Agency } \\
\text { (Ministry of } \\
\text { National } \\
\text { Development } \\
\text { Plan / Head of } \\
\text { Bappenas) }\end{array}$ & $\begin{array}{l}\text { Chief of staff of } \\
\text { the president's } \\
\text { office } \\
\text { (previously } \\
\text { monitoring and } \\
\text { controlling } \\
\text { development in } \\
\text { one particular } \\
\text { non-ministerial } \\
\text { (UKP4)) }\end{array}$ & $\begin{array}{l}\text { Ministry of the } \\
\text { Environment and } \\
\text { Forestry (DNPI \& } \\
\text { BP REDD+ } \\
\text { abolished) }\end{array}$ & $\begin{array}{l}\text { ICCTF (Indonesia } \\
\text { Climate Change Trust } \\
\text { Fund) }\end{array}$ \\
& $\begin{array}{l}\text { Presidential } \\
\text { regulation } \\
\text { No. 54/2009 on }\end{array}$ & $\begin{array}{l}\text { National Council } \\
\text { on Climate } \\
\text { Change and } \\
\text { REDD merged as }\end{array}$ & $\begin{array}{l}\text { Ministerial regulation } \\
\text { followed by } \\
\text { Presidential regarding } \\
\text { trust fund }\end{array}$ \\
\hline
\end{tabular}

\footnotetext{
${ }^{26}$ Based on interviews with the paratransit owners

${ }^{27}$ Based on interview with the Asbekindo Association
} 


\begin{tabular}{|c|c|c|c|c|}
\hline & $\begin{array}{l}\text { Planning } \\
\text { Agency, } \\
\text { Presidential } \\
\text { Decree No. 75/ } \\
1973 \text { on } \\
\text { National } \\
\text { Development } \\
\text { Planning Agency }\end{array}$ & $\begin{array}{l}\text { Presidential } \\
\text { Delivery } \\
\text { Unit on } \\
\text { Development } \\
\text { Monitoring and } \\
\text { Controlling }\end{array}$ & $\begin{array}{l}\text { a Presidential } \\
\text { decree no. } \\
16 / 2015\end{array}$ & \\
\hline Lead & $\begin{array}{l}\text { The Minister of } \\
\text { BAPPENAS }\end{array}$ & $\begin{array}{l}\text { Head of staff } \\
\text { (Minister level) }\end{array}$ & The President & Minister of BAPPENAS \\
\hline Modality & $\begin{array}{l}\text { Forum, formal } \\
\text { Meetings }\end{array}$ & $\begin{array}{l}\text { Led cross- } \\
\text { ministerial } \\
\text { meetings, vice } \\
\text { president-led } \\
\text { meetings, } \\
\text { President led } \\
\text { cabinet meetings }\end{array}$ & Working Groups & $\begin{array}{l}\text { Stakeholder } \\
\text { engagement forum }\end{array}$ \\
\hline $\begin{array}{l}\text { Official } \\
\text { stakeholders }\end{array}$ & $\begin{array}{l}\text { Ministries and } \\
\text { donor agencies }\end{array}$ & $\begin{array}{l}\text { Ministers, NGOs, } \\
\text { donor agencies }\end{array}$ & $\begin{array}{l}\text { Ministers and } \\
\text { NGOs }\end{array}$ & $\begin{array}{l}\text { Ministries, NGOs, } \\
\text { academia, chamber of } \\
\text { commerce } \\
\text { representative, donors }\end{array}$ \\
\hline $\begin{array}{l}\text { Role in climate } \\
\text { programming } \\
\text { and financing }\end{array}$ & $\begin{array}{l}\text { Oversee and } \\
\text { mainstream } \\
\text { climate change } \\
\text { into } \\
\text { development } \\
\text { plans }\end{array}$ & $\begin{array}{l}\text { Monitor and } \\
\text { oversee the } \\
\text { delivery of } \\
\text { development } \\
\text { priorities } \\
\text { including climate, } \\
\text { energy and } \\
\text { forestry }\end{array}$ & $\begin{array}{l}\text { The focal point } \\
\text { of United } \\
\text { Nations } \\
\text { Framework } \\
\text { Convention on } \\
\text { Climate Change } \\
\text { (UNFCCC) }\end{array}$ & $\begin{array}{l}\text { Multi-donor financing, } \\
\text { programme/project } \\
\text { selection, project and } \\
\text { programme } \\
\text { monitoring and } \\
\text { evaluation }\end{array}$ \\
\hline $\begin{array}{l}\text { Source of } \\
\text { Budget for } \\
\text { coordinator }\end{array}$ & $\begin{array}{l}\text { Central } \\
\text { government } \\
\text { budget }\end{array}$ & $\begin{array}{l}\text { Central } \\
\text { government } \\
\text { budget }\end{array}$ & $\begin{array}{l}\text { Central } \\
\text { government } \\
\text { budget }\end{array}$ & Overseas funding \\
\hline
\end{tabular}

Concerning the funding of the mitigation programme, ICCTF acted as its National Implementing Entity (NIE) for the fund in 2011. This ICCTF was the source of climate finance in Indonesia, and one of the smaller international climate trust funds. The establishment of ICCTF was delayed due to the lack of legal underpinning and incompatible systems of public and private financial management. The Presidential Decree on the government trust fund was signed two years after its establishment. Since then, it has become the legal basis for the fund. The decree only endorsed the trust to receive grants. The establishment of ICCTF also signalled Indonesia's willingness to demonstrate its commitment to take more control and ownership over the development and climate change programmes in Indonesia.

ICCTF has funded several pilot projects in Indonesia. There were three pilot projects, namely: (1) research and development of sustainable peatland management; (2) energy conservation in Pulp Paper Industry and Steel Industry; (3) public awareness, education and training regarding climate change (mitigation and adaptation). These three included the land use change and forestry (LUCF) sector. This sector has been a major emissions source since the early $1990 \mathrm{~s}\left(600 \mathrm{MtCO}_{2 \mathrm{e}}\right.$ in 1990 to $1200 \mathrm{MtCO}_{2 \mathrm{e}}$ in 2011). WRI (2014) data show that emissions from LUCF decreased slightly in 
2010, due to a lower forest conversion rate, but continued to be one of the dominant sources of Indonesia's GHG emissions. Besides ICCTF, Indonesia sought collaboration and bilateral relationships with other nations regarding climate change issues (Table 4.3).

Table 4.3: Bilateral relationships regarding climate finance in Indonesia.

Source: (Halimanjaya \& Maulidia, 2014)

\begin{tabular}{|l|l|}
\hline Country & Description \\
\hline Japan & Climate change programme loan which started in 2008 \\
\hline Germany & $\begin{array}{l}\text { The bank KfW has longstanding programmes to support energy efficiency and another } \\
\text { low-carbon technology } \\
\text { GIZ has supported two climate programmes (Paklim and Forclime in 2009); GIZ has to } \\
\text { support BAPPENAS to operationalise the ICCTF with strategic advice and capacity } \\
\text { development for climate change }\end{array}$ \\
\hline UK & $\begin{array}{l}\text { The UK has supported various initiatives on climate change in Indonesia since 2007 and } \\
\text { in 2011 after the main DFID office closed a climate change unit (CCU) }\end{array}$ \\
\hline AusAid & Financed several programmes to pilot REDD+* \\
\hline Norway & Presidential level with support from DNPI* \\
\hline
\end{tabular}

Note: In 2015, DNPI and BP-REDD+ has been dissolved and the tasks of both institutions were taken over by the Ministry of Environment and Forestry (Presidential Decree No.16/2015)

The budget for climate change mitigation (see Figure 4.1), as targeted by the national level, comes from the national budget (APBN). However, at the local level, the source of the budget may come from APBN, APBD, and Non-APBN/D. The basic mechanism for the transfer of budget from the central government to the regions (provincial level or local level) is called fiscal balance transfer (Dana Perimbangan). Key components are DBH (revenue sharing fund), DAU (general allocation fund), DAK (special allocation fund), and De-concentration/TP.

Characteristic of DAK as a top-down mechanism of central government could be that it needs to be arranged in accordance with bottom-up planning. This mechanism comes from the RAD-GRK document that was already compiled by the local government. However, in terms of RAD-GRK, this DAK is more tailored to the affordability of the central government. Instrument funding from DID is only suitable for middle-term planning. This fund used to target the education sector activities in the form of a block grant. It does not seem very flexible for using it for mitigation efforts (Badan Kebijakan Fiskal, 2012). There is no flexible way to use the resources (funding) that come from the central government to the local level from another level, when that would be more efficient. The national, provincial, and local level have their own responsibilities, including funding. 


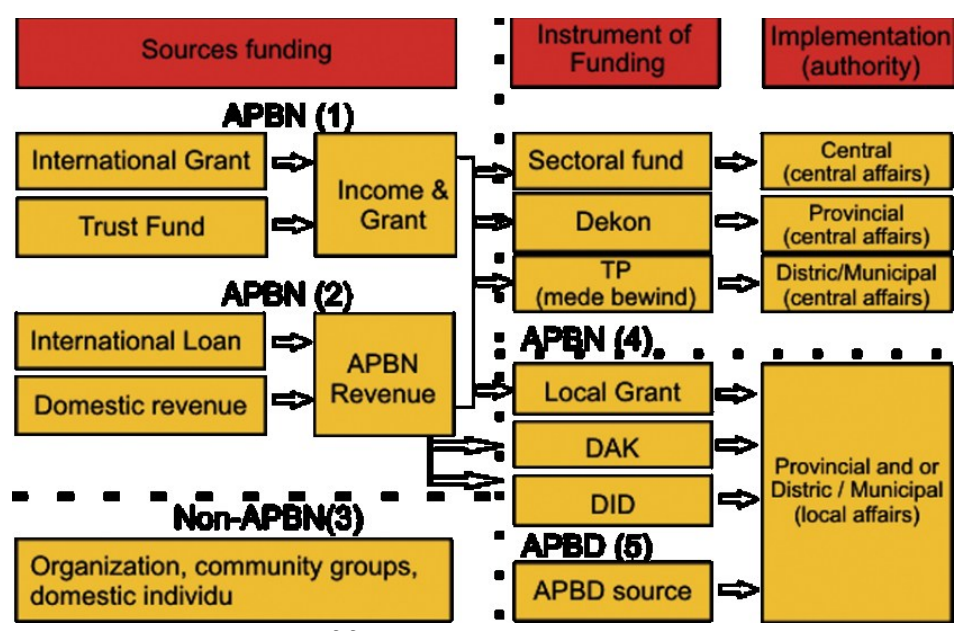

Figure 4.1: Source of funding on mitigation action at local level.

Notes: (1). Part of $41 \%$ commitment to lower GHG emissions; (2). Part of $26 \%$ commitment; (3). Possibly delivered as source for APBN / APBD; (4). Mitigation effort in local level, but not from APBD; (5) Source from APBD (Badan Kebijakan Fiskal, 2012).

The Provincial government was committed to perform the RAD-GRK through the establishment of working groups ${ }^{28}$ and an operational team to coordinate the mitigation and adaptation efforts ${ }^{29}$. There are two pivotal actors to maintain track of climate change mitigation, even if the programme itself has been broken down into various institutions. In terms of mitigation efforts in the energy and transport sector, central government has given discretion to target mitigation effort to the provincial authority. Notably, most efforts come from the energy sector, rather than the transport sector. The guideline from the central government has a strong impact on controlling and increasing the priority at the regional level. The local efforts do not set the technical manuals and directives.

We concluded that collaboration exists among all government levels in term of the emission measurement, as part of the environmental programme (emission measurement test is part of EKUP). However, in terms of flexibility, downscaling or upscaling across levels, when that would be more efficient, is challenging. This is because the rules must be followed as required and are not flexible.

For the emission measurement and TMB cases, there is a strong impact from the central government regarding facility provision. The local level is granted aid in the form of vehicles (buses) and DAK. However, to integrate the mitigation effort into the on-going programme needs

\footnotetext{
${ }^{28}$ Head Regional Planning Decree No. 674/Kep.1482/Fisik/2013

${ }^{29}$ Governor's decree no. 660.1/Kep.1163.BPLHD/2011
} 
to be pursued further. The central government has a strong impact on resources (budget and capacity building) for climate change mitigation. Even in the TMB case, the central government could possibly halt the bus provision, if the local government has difficulties in providing the necessary bus lanes, or when other obstacles appear in Bandung City (such as a conflict with paratransit owners). The provincial level was absent in the coordination of the transportation programme, especially in relation to managing the local levels in Bandung Basin areas (Bandung City, Bandung District, West Bandung District, and Cimahi City). However, according to their planning report, the Province of West Java prioritised waste management and rivers' management. This provincial role could be replicated in another context, such as transport sector management. The strong impact from the central government was not seen in the case of Paratransit management.

The Mayor of Bandung applied innovative aspects. Collaboration, innovation, and creativity become the key aspects echoed by Mayor of Bandung (www.iuran.id). Every citizen in Bandung City could submit their suggestions, environment reports, and complaints easily in regard to any services conducted by government. In developing pedestrian walks by Bandung City, the citizens are given the opportunity to express their opinions regarding feasible locations or those that need to be improved.

Paratransit, a local government programme authority, has been subject to improvement measures. The conversion from gasoline fuel to gas fuel has existed in Indonesia since the 1980s. Bandung City accelerated this conversion as a pilot project in 2007 for about 80 units with the help from the central government. However the programme ended because of (1) uncertainty of gas supply and the limited number of gas stations; (2) difficulties in converter kit supply; (3) too much water content in the fuel, resulting in inefficiency and damage to car engines (Antique \& Kurniawan, 2012; Susanti et al., 2010). Bandung municipality created another programme to increase the use of paratransit, such as a special public transportation day (Angkot day in the year 2013). This trial programme was research to unravel the congestion problem in Bandung City. However, this programme was not clear and was halted (Mulia, 2013; Rachmandy, 2013). Another policy tried to curb illegal public transport.

To tackle the congestion problem, Bandung City launched a School Bus programme to reduce road demand (to decrease the use of private vehicles). However, this was rejected by the other actors (paratransit owners and paratransit drivers), as they felt it would impact and reduce their incomes. However, the Mayor of Bandung stressed that their income were impacted more by other sources, such as the increasing number of motorcycles. The authority to limit the vehicles (such as motorcycles) is held by the central government. Local government is powerless to reduce the circulation of vehicles in Bandung City.

For all the policy instruments mentioned above (Emission measurement, TMB, Paratransit), it could be inferred that they are not influenced by the qualities of the governance regime. The extent and intensity were assessed to be low to moderate. Even the completeness of all levels involved was seen as moderate. Coherence and flexibility had the lowest evaluation and was assessed as very restrictive. The programmes have impacted certain co-benefits and on lowering 
GHG emissions. TMB and Paratransit are forms of public transport that encourage the reduction of fuel consumption.

Table 4.4: Assessment results for levels and scales.

Source: Collected data and interview analysis

\begin{tabular}{|c|c|c|c|c|}
\hline \multirow[t]{2}{*}{ Level \& scales } & \multicolumn{4}{|c|}{ Qualities of governance regimes } \\
\hline & Extent & Coherence & Flexibility & Intensity \\
\hline $\begin{array}{l}\text { Emission } \\
\text { measurement }\end{array}$ & $\begin{array}{l}\text { Moderate } \\
\text { (All levels dealing } \\
\text { with this issue) }\end{array}$ & $\begin{array}{l}\text { Moderate } \\
\text { (Only two levels } \\
\text { work together; } \\
\text { even some of the } \\
\text { funding from } \\
\text { central levels and } \\
\text { trusted the } \\
\text { provincial levels) }\end{array}$ & $\begin{array}{l}\text { Low } \\
\text { (It is hard to do } \\
\text { downscaling or } \\
\text { upscaling) }\end{array}$ & $\begin{array}{l}\text { Moderate } \\
\text { (Central } \\
\text { government has } \\
\text { the power to stop } \\
\text { the funding) }\end{array}$ \\
\hline $\begin{array}{ll}\text { Trans } & \text { Metro } \\
\text { Bandung } & \end{array}$ & $\begin{array}{l}\text { Moderate } \\
\text { (Only central } \\
\text { government and } \\
\text { local level } \\
\text { involved) }\end{array}$ & $\begin{array}{l}\text { Low } \\
\text { (Dependence on } \\
\text { central } \\
\text { government for } \\
\text { financing bus } \\
\text { provision; } \\
\text { provincial level } \\
\text { did not interfere) }\end{array}$ & $\begin{array}{l}\text { Low } \\
\text { (It is not possible } \\
\text { to give the } \\
\text { flexibility to the } \\
\text { local level to } \\
\text { provide their } \\
\text { facilities) }\end{array}$ & $\begin{array}{l}\text { Moderate } \\
\text { (Central } \\
\text { government has } \\
\text { the power to halt } \\
\text { the resources) }\end{array}$ \\
\hline Paratransit & $\begin{array}{l}\text { Low } \\
\text { (Only local level } \\
\text { involved) }\end{array}$ & $\begin{array}{l}\text { Low } \\
\text { (Only local level } \\
\text { involved) }\end{array}$ & $\begin{array}{l}\text { Low } \\
\text { (Not flexible; } \\
\text { based on } \\
\text { administrative } \\
\text { level) }\end{array}$ & $\begin{array}{l}\text { Low } \\
\text { (only local } \\
\text { government has } \\
\text { to do with their } \\
\text { program) }\end{array}$ \\
\hline Assessed as: & Low to moderate & Low / Restrictive & Low / Restrictive & Low to moderate \\
\hline
\end{tabular}

Noted: green colour means 'moderate'; red colour means 'low'

In comparing all policy instruments researched, the paratransit policy has the lowest quality of the governance regime context regarding levels and scales.

\subsection{Actors and Networks}

All stakeholders are involved in climate change mitigation management within the various sectors. In the planning process, all sectors at the national level have given authorities (permission and instructions) to make their targets and guidelines for tackling the GHG emissions reduction. However, in Indonesia, the actors dealing with issues will depend on their respective policymakers at all levels. To exemplify this, it can be seen that stakeholders dealing with climate 
change at the national level (DNPI and BP REDD+) have been eliminated in Jokowi era ${ }^{30}$. In general, restructuring the public organisation is a requirement for achieving good governance in the context of the provision services (Jones, 2010). However, this also happens in the regional or local organisations, which is based on a political decision (Hertati, Supriyono, Zauhar, \& Wijaya, 2015; Pratiwi, 2015).

In the TMB case, not all relevant actors were involved in the planning and implementation processes. The civil society and paratransit owners were often neglected in all processes, especially in the initial stage. Generally, after the conflicts and they were publicised in the media (Lazuardi, 2016; Liputan 6, 2008; Yan, 2015), the government conducted a joint discussion. For some local level actors, this low participation often happened if the paratransit owners bargained with unreasonable conditions. The local government felt that to solicit opinion was always done via a bottom-up mechanism. There were no representative actors from the paratransit drivers who, instead, came from the cooperative association with multiple paratransit representatives. The paratransit drivers, in particular, were excluded from the network. Understandably, the level of income of paratransit drivers always have been lower.

The new programmes to break the bottleneck (such as traffic congestion) often disregarded the paratransit driver (development of TMB and Free School Bus). There is a lower degree of trust from paratransit actors for the local government of the programme. Thus, this situation is not mutual. The transport department feels that the privately owned paratransit vehicles should be reduced to make services better. The transport department was planning to involve the paratransit owner to become a member of the TMB consortium. This involvement was a form of trust from the local government. However, this involvement still did not exist when the research took place.

A financing system that relies on government budgets (local or national) often impedes the operation of TMB. The operational TMB was halted on some occasions for several weeks without further notice. This reduced the level of public trust (users) for the TMB. On the contrary, paratransit had a stable operational system. The public trust for paratransits was higher than the $\mathrm{TMB}$, even with the lack of some services.

However, the networks of actors for emission measurement (emission vehicle test and Adipura programme or cleanliness city) existed in stable structures. Their relationship has been ongoing since 1986, when the Ministry of the Environment and Forestry (at that time the Ministry of the Environment) launched the first Adipura programme. Since then, the emissions test became part of Blue-Sky programme and was merged into the Adipura programme in 2014. Regulation has stipulated that, for emission measurement for mitigation action, entities should report their emissions (not only GHG, but also waste management) including their mitigation action.

\footnotetext{
30 President Jokowi's administration between 2014-2019, more focused on equitable infrastructure development (policy hub context)
} 
Industrial activities also have to self-report and inform this to the municipal level. However, the report of GHG emissions from the transport department to local EMA was not conducted. The transport department suggests that the emission report must be implemented by the local EMA. Asking other government actors in local level also has to the same conclusion (Local Planning Agency, Spatial Planning).

The networking within financial institutions was difficult to achieve at the local level, given the poor access to information and the lesser experience, compared to central government. However, this obstacle could be reduced by a leader with vision and a good record of accomplishment working with international stakeholders. At a local level, the mayor figure has the greatest impact in managing collaboration between actors and networks. In this case, the interaction-institutionalised stability at each level already existed, even without assistance from the national level. The local level leader had the strongest impact on the progress of programmes (management reform) and did not hesitate to dismiss the implementer of any institution (bureaucracy actors) when a programme was stagnant. The social capital sharing is limited to the governmental actors, especially in the paratransit and TMB cases. The motivation to make better public transport comes from NGOs and government. However, the paratransit still runs a business as usual operation.

Lack of municipality resources can be resolved by building a network. This exists outside of the bureaucracy and can be accessed, stimulated and facilitated by the social media information (such as Twitter, Facebook) to enable it to work effectively. Using the media as a tool to create a network has been the right means to engage massive collaboration. Facebook and Twitter have become the popular way for citizens in Bandung to contact the Mayor. Generally, governments use their power to fundraise for development (Gwilliam, 2002; Jaeger et al., 2015). This difference for Bandung is its public fund raise with individuals via the media. This provides flexibility to add new actors or even lead to shift from one actor to another if there have some pragmatic reasons.

Table 4.5: Assessment results for actors and networks. Source: Collected data and interview analysis

\begin{tabular}{|c|c|c|c|c|}
\hline \multirow{2}{*}{$\begin{array}{ll}\text { Actors and } \\
\text { networks }\end{array}$} & \multicolumn{4}{|c|}{ Qualities of governance regimes } \\
\hline & Extent & Coherence & Flexibility & Intensity \\
\hline $\begin{array}{l}\text { Emission } \\
\text { measurement }\end{array}$ & $\begin{array}{l}\text { Moderate } \\
\text { (Almost all } \\
\text { relevant actors } \\
\text { engaged in } \\
\text { activities including } \\
\text { association } \\
\text { workshop, } \\
\text { government in all } \\
\text { levels) }\end{array}$ & $\begin{array}{l}\text { Moderate } \\
\text { (They already } \\
\text { have the } \\
\text { established } \\
\text { standard } \\
\text { procedure) }\end{array}$ & $\begin{array}{l}\text { Low } \\
\text { (It is hard to do } \\
\text { downscaling or } \\
\text { upscaling) }\end{array}$ & $\begin{array}{l}\text { Moderate } \\
\text { (There is no strong } \\
\text { impact from } \\
\text { Ministry or West } \\
\text { Java EMA on } \\
\text { pushing the Local } \\
\text { Transport } \\
\text { Department or } \\
\text { Local EMA to } \\
\text { conduct the } \\
\text { measurement) }\end{array}$ \\
\hline
\end{tabular}




\begin{tabular}{|c|c|c|c|c|}
\hline \multirow{2}{*}{$\begin{array}{ll}\text { Actors and } \\
\text { networks }\end{array}$} & \multicolumn{4}{|c|}{ Qualities of governance regimes } \\
\hline & Extent & Coherence & Flexibility & Intensity \\
\hline $\begin{array}{ll}\text { Trans } & \text { Metro } \\
\text { Bandung } & \end{array}$ & $\begin{array}{l}\text { Low } \\
\text { (Only central } \\
\text { government and } \\
\text { local level are } \\
\text { involved, other } \\
\text { actors (paratransit } \\
\text { driver and users) } \\
\text { rarely engage), } \\
\text { other institution } \\
\text { such as Public } \\
\text { works rarely } \\
\text { involved by } \\
\text { transport } \\
\text { department }\end{array}$ & $\begin{array}{l}\text { Low } \\
\text { (Interaction } \\
\text { strength is low, } \\
\text { the operational is } \\
\text { sometimes } \\
\text { halted) }\end{array}$ & $\begin{array}{l}\text { Low } \\
\text { (It is not possible } \\
\text { to give the } \\
\text { flexibility for local } \\
\text { level to provide } \\
\text { their facilities) }\end{array}$ & $\begin{array}{l}\text { Moderate } \\
\text { (Local government } \\
\text { has the power to } \\
\text { halt. In some } \\
\text { occasion, halted by } \\
\text { paratransit) }\end{array}$ \\
\hline Paratransit & $\begin{array}{l}\text { Low } \\
\text { (Only local } \\
\text { government } \\
\begin{array}{l}\text { associations are } \\
\text { involved) }\end{array}\end{array}$ & $\begin{array}{l}\text { Moderate } \\
\text { (Occasionally the } \\
\text { paratransit } \\
\text { protested the } \\
\text { TMB operational) }\end{array}$ & $\begin{array}{l}\text { Low } \\
\text { (Not flexible; } \\
\text { based on } \\
\text { administrative } \\
\text { level) }\end{array}$ & $\begin{array}{l}\text { Low } \\
\text { (Local government } \\
\text { has worked based } \\
\text { on their program) }\end{array}$ \\
\hline Assessed as: & Low / Restrictive & $\begin{array}{l}\text { Moderate } \\
\text { supportive }\end{array}$ & Low / Restrictive & $\begin{array}{l}\text { Moderate } \\
\text { supportive }\end{array}$ \\
\hline
\end{tabular}

Noted: green colour means 'moderate'; red colour means 'low'

\subsection{Problem Definitions and Goals}

The main perspectives on climate change mitigation are national. Participation from transport sector stakeholders (operator, paratransit driver, local government, and society) is not really bolstered and their perspectives are rarely conveyed. The effort to promote public transportation often conflicts with efforts to promote the automotive industry domestic market. This conflict happens, not only between NGOs and government institution, but also between multilevel government relationships. Local government did not have the authority to reduce the number of vehicles in the city. Some efforts to reduce the traffic density in Bandung City have been done through the four in one programme besides the existing public transport provision. Programmes to limit the period of validity of vehicles only increase the tax on owners. This will not directly halt the number of vehicles purchased. One of the Regional Revenue Officers said "From the regulation, vehicle age restrictions only to equalise taxes on vehicles from the year 1980 production, and the progressive taxable car not too much influence on the sales of new vehicles. However, the central government also still remains to encourage the automotive industry".

Most programmes for local mitigation actions are initiated from central government (Ministry of the Environmental and Forestry, Ministry of Public Works, Ministry of Transportation and Bappenas). Dealing with global problems (e.g. tackling climate change) is new for the Indonesia 
government, especially including local level perspectives. An example is an ambitious programme to connect Jakarta to Bandung via high-speed train that is administered at the national level. However, conflict has appeared from the presidential regulations for the central government guarantee $^{31}$. This programme also neglected the environmental goals in a preference for the economic perspective.

All goals translated from national level are policy instruments that existed previously. The requirement of international agreements has not been fully implemented at the local level to deal with the local traffic congestion and air pollution.

Some mitigation projects arise from bilateral partnership with other nations (GIZ, MEITI, AuSAID). The TMB planning and operation did not consider all stakeholder perspectives. The TMB has received central government support through provision of vehicles and aims to help Bandung City fulfil its provision of public transport.

However, existing public transport in Bandung has different views. The paratransit owners, including drivers, NGOs and users, are not engaged in planning and operation and conflict appears in implementation as these owners and drivers rejected the TMB. Recently, the programme of School Bus in Bandung was also rejected by paratransits who felt their livelihood would be impacted. Lack of preparation and funds were the main reason for the conflict. The local level could not provide the shelters and bus lane for the TMB. Therefore, it would be increase congestion that existed given the mixed public transport (paratransit and DAMRI).

Transportation experts conclude that TMB has not reduced the use of private cars or motorcycles. It has challenged people to use public transport, instead of their private vehicles, but has not unravelled the bottlenecks. TMB has not integrated with other transportation modes in Bandung City. As a result, congestion will continue and could spill over into streets far from the city centre. The TMB operating system is different from BRT in other areas. Jakarta has the special lanes for busway (BRT) that differ from other vehicles. There are 10 busway corridors in Jakarta with a capacity of 524 units for 250,000 passengers/day. In Bandung City, only three corridors exist serving 36 buses with 664 passengers/day ${ }^{32}$. The characteristics of TMB users show $46 \%$ do not own vehicles and $40 \%$ work in the private sector and in the lower to middle-income average.

In general, paratransits are owned by private, small enterprises or by the unions (cooperation). Their aim is to help citizens obtain better public services. This often contradicts the need to obtain adequate income. The public transport survey showed the community wants public transport to be more comfortable, safe and secure (Bappeda, 2013). The goals of local government are similar

\footnotetext{
${ }^{31}$ Presidential decree No. 3/2016 (article 25) regarding acceleration of National Strategic Project stated that central government could give a guarantee for the strategic national program; However, in Presidential Decree No. 107/2016 regarding acceleration of high-speed train Bandung-Jakarta stated there will be no guarantee from the central government pertaining the budget.

32 Data from January - June 2013 for corridor 2 (Local Transportation Department)
} 
to the community goals. However, to reduce the use of paratransit and convert their transport modes into the TMB will involve high cost.

There is a need for other support, especially from the provincial level, to make better public transport in Bandung City because public transports are not only owned by Bandung City itself. One of the local actors said "the provincial level is needed to coordinate and take action in the transport system in Greater B.M.A, not only work on Citarum river issues". The organisation umbrella for paratransit is the Road Transport Organisation (Organda) that supervises public transport cooperatives. The purpose of the paratransit is to serve as a feeder ${ }^{33}$ to the TMB or DAMRI. Generally, conflict resolution for paratransit owners occurs at the local level. Other activities undertaken by local government are to reduce the conflict between the existing public transports.

A 2009 report of Business Competition Supervisory Commission showed the local government involved private entrepreneurs in implementing the Bus Rapid Transit of TMB (KPPU, 2009), as follows:

1. Community Transport Cooperation (Kopamas) that already has five routes of paratransit trajectory

2. Transport business coaching cooperative (Koperasi Bina Usaha Transportasi Indonesia or Kobutri), that has three routes of paratransit trajectory

3. New Bandung orderly cooperative (Koperasi Bandung Tertib or Kobanter Baru) that has 27 paratransit route trajectories

4. DAMRI Urban bus transport unit (UABK) Bandung.

However, the Bandung Transport Department in 2016 reported that consortium planning was far from a reality. The existing TMB uses another format of management: the designation of the operator based on auction. The local government is aware of the poor management of paratransit. The transportation master plan for Bandung City sees paratransit needing reform. A daily instalment system of paratransit is one reason for the lack of transportation services as drivers have to collect money fares based on their specified daily targets as set by the paratransit owners.

Central government generally has failed in their supervision function and has remained weak in planning in Bandung City, as elsewhere. Some projects have different systems and result in different impact performances. Involving relatively inexperienced local government in these projects has led to other problems. The TMB implementation required collaboration and partnership with the private sector. Research by Goldman and Gorham (2006) showed that BRT faced an institutional challenge from this innovation aspect. To successfully implement BRT required collaboration in many cities between two or more institutions, each with their own

\footnotetext{
${ }^{33}$ There are two corridors in feeder technic in road network; Bus will service the main corridor and the small cars (paratransit) will serve the small area (Bappeda, 2013)
} 
responsibilities, but where a single agency or coordinating body set policy for the planning and real-time management of bus corridors.

Local level actors, including EMA, Development Planning Agency, and Spatial and Public Works Agency, regard the Transport Department as responsible. Several programmes (e.g. limiting the use of the private vehicle, improving public transportation and vehicles feasibility) contribute to reducing GHG emissions. However, the Transport Department faces conflicts between TMB and Paratransit on and, as the authority to manage routes has to deal with Paratransit drivers regarding how these intersect. Other problems include the decrease in road capacity used up by $\mathrm{TMB}$ and the increasing number of transports.

Local levels insist the current problems have to be dealt by the provincial level. The regional institution (provincial level) ${ }^{34}$ must perform their tasks in coordinating and facilitating cities in West Java region. For example, one person mentioned, "congestion issues will not be solved well if this issue still tackled only in one city or one district, it should be set in the provincial level". However, in handling these problems, whether settled by local level or regional level, does not address the problem of GHG emissions. The problem of climate change mitigation is not the priorities in Bandung City. The urgent issue remains downstream (congestion and pollution) and not upstream (GHG emissions), as stated by Local Development Planning Agency.

The regional level generally supports the local level in dealing with the environmental problems. For example, tackling the flooding issue (Citarum River) and waste problem ${ }^{35}$. The local level acknowledges that the mitigation programmes are conceived as set up by the central government. The mitigation programmes have not been prioritised as the environmental issue to be dealt with the local or regional level as the list of programmes prioritise waste and flood issues at the regional level. The problems to be addressed locally have increased due to the additional programmes tasked by central government, such as emission test programme and climate change mitigation. The emission test programme is held yearly at every level of government. The provincial level performs the emission test for the regional area and Bandung City is conducted locally. Sometime, the programmes are conducted in good collaboration, particularly for dissemination (e.g. emission test for 1.089 vehicles in Bandung City) (detiknews, 2011).

There are some opportunities to reassess goals from the leadership at the local level. According to Bulkeley (2009), two of the primary motivations for climate policy and action by local governments are leadership and issue framing. In terms of leadership, Bulkeley et.al, (2009) found that individual political 'champions', such as the Mayor of Yogyakarta, were important actors supporting advanced initiatives (e.g., programme to retrofit lights and reduce air conditioning hours and bulbs, change travel behaviour, and develop BRT). Issue framing was considered a critical factor in climate change policy and action. First, it was important for energy

\footnotetext{
${ }^{34}$ As mention by EMA, Development Planning and Spatial planning Agency of Bandung City

${ }^{35}$ Based on local planning development agency in Bandung City
} 
security and fuel efficiency to help eradicate poverty. Second, framing low-carbon strategies, in terms of air quality and health problems, have led to some initiatives by local actors in all of the case studies. Efforts to try this energy security and low-carbon strategy has been adapted by local government by changing from fossil fuel (gasoline) into gas fuel to reduce air pollution and increase fuel efficiency. Collaboration between Bandung City and Gas National Company (PGN) was established. The Mayor planned to convert the paratransit, buses and government vehicles targeting 5,000 unit in 12 months (Rosadi, 2016). However, only three petrol stations in Bandung City can deliver gas fuel.

Ridwan Kamil, the Bandung Mayor, dismissed the Head of Transportation in Bandung City (Tempo, 2016) saying "a lot of failures, of road markings, the reform of public transportation, taxis which are not metered, taxis monopolised, TMB halted, cable car late (groundbreaking)". The leader knew that to keep the programme on the right track required hard effort. This is the example of reward and punishment in the local government, which is an appropriate strategy. All actors saw this as a positive signal of the leadership in Bandung City. On this occasion, Bandung local government had an opportunity to re-assess the goals to improve the transport sector in Bandung City. Positive response came from TMB with its goals to increase the level of services implementing e-ticketing in probation time. However, improvement of public transportation, such as TMB, does not always benefit other modes, such as paratransit. The aim of Bandung Mayor is to decrease the use of paratransit and use of larger vehicles (TMB, DAMRI or School bus) to reduce the coherence and intensity of the programmes.

Table 4.6: Assessment results for problem perspectives and goal ambitions. Source: Collected data and interview analysis

\begin{tabular}{|c|c|c|c|c|}
\hline \multirow{2}{*}{$\begin{array}{l}\text { Problem } \\
\text { perspectives and } \\
\text { goal ambitions }\end{array}$} & \multicolumn{4}{|c|}{ Qualities of governance regimes } \\
\hline & Extent & Coherence & Flexibility & Intensity \\
\hline $\begin{array}{l}\text { Emission } \\
\text { measurement }\end{array}$ & $\begin{array}{l}\text { Low } \\
\text { (The various } \\
\text { problems that has } \\
\text { to be addressed in } \\
\text { local level increase } \\
\text { due to additional } \\
\text { programmes from } \\
\text { the central } \\
\text { government) }\end{array}$ & $\begin{array}{l}\text { Moderate } \\
\text { (All levels are not } \\
\text { conflicted with } \\
\text { each other } \\
\text { regarding the } \\
\text { monitoring) }\end{array}$ & $\begin{array}{l}\text { Low } \\
\text { (It is hard to do } \\
\text { downscaling or } \\
\text { upscaling) }\end{array}$ & $\begin{array}{l}\text { Low } \\
\text { (Different } \\
\text { perspective of } \\
\text { goals from all } \\
\text { level) }\end{array}$ \\
\hline $\begin{array}{ll}\text { Trans } & \text { Metro } \\
\text { Bandung } & \end{array}$ & $\begin{array}{l}\text { Low } \\
\text { (local level with } \\
\text { minimum } \\
\text { resources has to } \\
\text { deal with various } \\
\text { problems that } \\
\text { occurs in the field) }\end{array}$ & $\begin{array}{l}\text { Low } \\
\text { (There is } \\
\text { competition } \\
\text { between public } \\
\text { transport } \\
\text { organisations, } \\
\text { there are also }\end{array}$ & $\begin{array}{l}\text { Low } \\
\text { (It is possible to } \\
\text { re-assess goal, } \\
\text { however } \\
\text { concerning the } \\
\text { sector }\end{array}$ & $\begin{array}{l}\text { Moderate } \\
\text { (Transport } \\
\text { department has } \\
\text { different goals } \\
\text { regarding climate } \\
\text { change } \\
\text { mitigation; }\end{array}$ \\
\hline
\end{tabular}




\begin{tabular}{|l|l|l|l|l|}
\hline & & $\begin{array}{l}\text { other } \\
\text { competitions } \\
\text { between } \\
\text { transport } \\
\text { department with } \\
\text { another } \\
\text { department such } \\
\text { as Public works, } \\
\text { Spatial plan, etc }\end{array}$ & $\begin{array}{l}\text { perspective it is } \\
\text { hard to do) }\end{array}$ & $\begin{array}{l}\text { however, they } \\
\text { encourage the } \\
\text { TMB } \\
\text { development) }\end{array}$ \\
& $\begin{array}{l}\text { Low } \\
\text { (Contradictive } \\
\text { with TMB goals) }\end{array}$ & $\begin{array}{l}\text { Low } \\
\text { (re-assessment } \\
\text { goals based on } \\
\text { resources } \\
\text { availability from } \\
\text { (Only local } \\
\text { government has to } \\
\text { deal with } \\
\text { association, } \\
\text { drivers, users) }\end{array}$ & $\begin{array}{l}\text { Low } \\
\text { government) }\end{array}$ & $\begin{array}{l}\text { government has } \\
\text { the programme to } \\
\text { diminish the } \\
\text { paratransit) }\end{array}$ \\
\hline Assessed as: & Low / Restrictive & Low / Restrictive & Low / Restrictive & Low to Moderate \\
\hline
\end{tabular}

Noted: green colour means 'moderate'; red colour means 'low'

\subsection{Strategies and Instruments}

The Government of Indonesia (Gol) has established a strategic framework to enable climate change action by ratifying laws (based on Protocol Kyoto and Climate Change Action) that integrate the national, provincial, and local levels. However, many sector strategies are not incorporated into the local level as they are not implemented directly as a particular programme or set of activities that makes climate change a priority. This condition occurs in the transport, forestry, agriculture, energy, and waste sectors. The RAD-GRK and RAN-GRK also have different strategies and different achievements.

The climate change mitigation and adaptation programmes have national level policies set in eight forms involving the following steps: (1) considering climate resilience; (2) decentralising strategy to overcome gaps in regions; (3) promoting socio-cultural human development; (4) developing local economy and improving fiscal capacity; (5) provision of decent housing and settlements; (6) establishment of a compact city (efficient utilisation and land stewardship justice); (7) improving the environmental health quality and managing climate change disaster and its adaptation; (8) increasing human resources capacity, institutional, good governance principles, and encouraging the emergence of visionary leadership. The national policy mitigation efforts are not expressed in detailed prescription as most programmes focus on adaptation efforts and anticipating the impact of climate change.

Gol has pledged Nationally Appropriate Mitigation Actions (NAMAs) to the United Nations Framework Convention on Climate Change (UNFCCC) as described in Table 4.7. 
Table 4.7: Cases of NAMAs and Registry.

Source: Collected data and interview analysis

\begin{tabular}{|c|c|c|c|c|}
\hline \multirow{2}{*}{$\begin{array}{l}\text { Mitigation } \\
\text { potentials }\end{array}$} & \multicolumn{2}{|c|}{ Scope } & \multirow{2}{*}{$\begin{array}{l}\text { Monitoring, } \\
\text { Reporting, } \\
\text { Verification } \\
\text { (MRV) }\end{array}$} & \multirow[t]{2}{*}{ Authority } \\
\hline & Action & Enabling & & \\
\hline $\begin{array}{l}\text { National } \\
\text { Mitigation Action } \\
\text { Plan (RAN GRK) }\end{array}$ & $\begin{array}{l}33 \text { provinces, } \\
\text { five sectors } \\
26 \%(0.767 \text { Giga } \\
\left.\text { ton } \mathrm{CO}_{2 \mathrm{e}}\right) \\
15 \% \text { for total } \\
41 \%(1.189 \mathrm{Giga} \\
\left.\text { ton } \mathrm{CO}_{2 \mathrm{e}}\right)\end{array}$ & $\begin{array}{l}\text { Presidential decree no. } \\
61 / 2011\end{array}$ & $\begin{array}{l}\text { Monitoring and } \\
\text { evaluation } \\
\text { reports (MER) }\end{array}$ & $\begin{array}{l}\text { Host: Bappenas } \\
\text { (secretariat) }\end{array}$ \\
\hline $\begin{array}{l}\text { Previously } \\
\text { Reducing } \\
\text { Emissions from } \\
\text { Deforestation } \\
\text { and Forest } \\
\text { Degradation } \\
\text { (REDD+) }\end{array}$ & $\begin{array}{l}44 \text { pilot projects } \\
\text { of deforestation } \\
\text { and forest } \\
\text { degradation }\end{array}$ & $\begin{array}{l}\text { Presidential decree no. } \\
5 / 2013\end{array}$ & MRV for REDD+ & $\begin{array}{l}\text { Host: Ministry } \\
\text { of Environment } \\
\text { and Forestry } \\
\text { (MOEF) }\end{array}$ \\
\hline $\begin{array}{l}\text { Previously Clean } \\
\text { Development } \\
\text { Mechanism } \\
\text { (CDM) }\end{array}$ & $\begin{array}{l}140 \text { of CDM } \\
\text { Projects have } \\
\text { been registered } \\
\text { in UNFCCC } \\
27 \text { from } 140 \\
\text { projects have } \\
\text { Certified } \\
\text { Emission } \\
\text { Reduction (CER) } \\
\text { with total } 75 \\
\text { Mton } \mathrm{CO}_{2 \mathrm{e}}\end{array}$ & $\begin{array}{l}\text { Act no. 23/1997 } \\
\text { concerning } \\
\text { Environmental } \\
\text { Management; Act No. } \\
\text { 17/2004 Kyoto Protocol } \\
\text { Ratification }\end{array}$ & $\begin{array}{l}\text { Project based } \\
\text { MRV }\end{array}$ & Host: MOEF \\
\hline $\begin{array}{l}\text { Joint } r \text { credit } \\
\text { mechanism }(\mathrm{JCM})\end{array}$ & $\begin{array}{l}\text { Land use, } \\
\text { renewable } \\
\text { energy, energy } \\
\text { efficiency, waste } \\
\text { management, } \\
\text { transport }\end{array}$ & $\begin{array}{l}\text { Coordinating ministry } \\
\text { of economics decree no } \\
\text { KEP- } \\
\text { 50/M.EKON/05/2012 }\end{array}$ & $\begin{array}{l}\text { Project based } \\
\text { MRV }\end{array}$ & $\begin{array}{l}\text { Host: } \\
\text { MOE/MEITI- } \\
\text { Japan } \\
\text { MOEF (DNPI), } \\
\text { Coordinating } \\
\text { Ministry of } \\
\text { Economics } \\
\text { Gol \& Japan }\end{array}$ \\
\hline $\begin{array}{l}\text { Pilot- Millennium } \\
\text { Challenge } \\
\text { Account }\end{array}$ & $\begin{array}{l}\text { Green prosperity } \\
\text { (renewable } \\
\text { energy } \\
\text { development } \\
\text { and green } \\
\text { knowledge) }\end{array}$ & $\begin{array}{l}\text { Presidential decree No. } \\
80 / 2011\end{array}$ & MRV & $\begin{array}{l}\text { Host: Bappenas } \\
\text { Gov: Board of } \\
\text { trustees (trust } \\
\text { fund) }\end{array}$ \\
\hline
\end{tabular}

Emission measurement is regularly conducted by local government (Local EMA) and, at first, was not intended as a programme to lower GHG emissions. Interview with Local Transportation Department of Bandung City reported "action against climate change does not exist, but there are the usual routine activities that may be associated with GHG such as emission test and vehicle 
validity test (KIR test) for public transport and transport of goods in every six month". However, the emission test data do not all inform about GHG emissions. The emphasis is on annual measurement of the air pollution control; even though there are some self-measurements of environmental quality, including air quality from industries. There was no conflict in the measurement system in all programmes. In a vehicle validity test by the Transportation Department and vehicle emission test conducted by EMA, it was possible to combine both and these complement each other. However, there is still a need to acknowledge the emission from the trip-based analysis. This data is specific and accurate to improve the GHG emissions inventory data.

Other programmes exist that are relevant to the climate change mitigation programme. These include: Four-in-One on every Saturday carried out at the Pasteur Street, Car-Free Day (CFD) on every Sunday and also Car-Free Night (CFN) in the centre area of Bandung City (Asia Africa Street), which also has the same objective to restrain vehicle entry. However, in guidelines produced by the Local Environmental Management Agency (EMA), various programmes are already established in terms of mitigation action. The programmes are to develop the infrastructure and facilities to accelerate the public transport provision, especially TMB. Those programmes are expected to help lower GHG emissions.

Public transports are potential sources of emissions of GHG besides private vehicles (cars and motorcycle). The TMB is intended for BRT owned by local government but competes with other public transports, especially privately owned paratransits that occupy most segments in Bandung City. The bus 'DAMRI' is the oldest government-owned enterprise and still dominates as public transport in Bandung City. However, each public transport has their own customers and still cannot replace the use of private vehicles. There are some scenarios to change the use of private vehicles, such as limitation of on-site parking, law enforcement to the private vehicles and expanding and improving pedestrian access in Bandung City. The TMB strategy has to be managed in accordance with Bus Rapid Transit and intends to separate their lane from other modes of transportation. This will increase the competitiveness of public transport. Paratransits have experienced the roll out energy efficient (gas fuel) programme that was halted given problems of adaptation of the technology, maintenance obstacles, and lack of availability of gas stations ${ }^{36}$.

The information (NAMA's agreements) from central government regarding the climate change mitigation programme and strategies was not delegated to regional and local levels. The action plan already created in regional and local levels was not implemented in direct programmes. As a guideline, an action plan that is divided into several sectors is not seen as an obligation for regional and local level institution to follow .... "We make an action plan only as a target deadline.

\footnotetext{
${ }^{36}$ Based on interviews analysis with stakeholders in 2016
} 
While the action was on the field itself [....] yes, it was still difficult to calculate the emission inventory [...] so it is only to make a document." ${ }^{137}$

As mentioned by a West Java EMA representative "Framing action plan from central or regional level actually functions as a guideline for the local level to implement their action. However, the government position which is based on Law no 23/2014 regarding government as well as local government and added by Law no. 6/2014 about the villages, regulates the local government to become autonomous region". It was also reinforced by the Local Development Agency that there is a connection and alignment between central or regional government with local government. It was their right to undertake their programmes based on their own priorities, vision and mission as decided by the elected mayor.

Other programmes to reduce GHG emissions, such as encouraging the use of non-motorised transport bicyclist policy has been initiated in Bandung City. However, it worked a few occasions only (CFD and cycling every Friday). There is no regulation to provide parking facilities and, as yet, bike lanes are not incorporated into only in a few areas. Some public facilities had provided parking lot for bikes. Cycling faces obstacles. Bicyclists have to share lanes with motorcycles that are dominant in Bandung City. There is a lack of awareness and respect from motorised drivers and paratransit. Incidents often happen because of sudden stops by other road users.

Law enforcement in parking management could benefit bike use and has already been implemented in some places to good effect. Private vehicles that disobeyed regulations have their car clamped by the task force. This activity is more effective than the impounding and removal of vehicles. Congestion strategies involve re-routing and re-pooling for paratransit routes to manage the optimal supply and demand. Route changing did pose risks, particularly at intersecting routes where collisions happened when dissemination of information by the local government was lacking (Wulandari, 2015).

The synergy of national, regional, and local levels to achieve harmony is a strategic objective for climate change programmes. However, decentralised power tends to exclude national programming. Local perspectives see the synergy of urban planning development reached when it accords to the principle of community involvement through the bottom-up mechanism. Feedback is maintained by an annual consensus development plan (representative of district level). Local meeting forums are one way to gather the aspirations (for a programme) that could be implemented locally level, especially in Bandung City. Climate change issues, particularly via mitigation of GHG emissions are rarely seen compared with other issues, such as river pollution, waste, flood, and congestion in the city.

\footnotetext{
${ }^{37}$ Quote based on face-to-face interview with Local Environmental Management Agency representative on
} 3 September 2015 
Table 4.8: Assessment results for strategies and instruments. Source: Collected data and interview analysis

\begin{tabular}{|c|c|c|c|c|}
\hline \multirow{2}{*}{$\begin{array}{l}\text { Strategies and } \\
\text { instruments }\end{array}$} & \multicolumn{4}{|c|}{ Qualities of governance regimes } \\
\hline & Extent & Coherence & Flexibility & Intensity \\
\hline $\begin{array}{l}\text { Emission } \\
\text { measurement }\end{array}$ & $\begin{array}{l}\text { Moderate } \\
\text { (Not all strategies } \\
\text { are implemented, } \\
\text { measurements are } \\
\text { only estimated } \\
\text { based on traffic } \\
\text { counting and air } \\
\text { pollution; other } \\
\text { strategy that need } \\
\text { further } \\
\text { collaboration is still } \\
\text { disregarded) }\end{array}$ & $\begin{array}{l}\text { Moderate } \\
\text { (They already } \\
\text { have the } \\
\text { standard } \\
\text { procedure and it } \\
\text { is established) }\end{array}$ & $\begin{array}{l}\text { Low } \\
\text { (It is possible to } \\
\text { combine the } \\
\text { emission } \\
\text { measurement, } \\
\text { however there is } \\
\text { still a problem } \\
\text { with the cross- } \\
\text { sectoral issue) }\end{array}$ & $\begin{array}{l}\text { Low } \\
\text { (Central } \\
\text { government has } \\
\text { the power to } \\
\text { change the } \\
\text { system and to } \\
\text { facilitate this } \\
\text { measurement) }\end{array}$ \\
\hline $\begin{array}{ll}\text { Trans } & \text { Metro } \\
\text { Bandung } & \end{array}$ & $\begin{array}{l}\text { Low } \\
\text { (policy strategy to } \\
\text { conversion of the } \\
\text { paratransit into } \\
\text { bus; still not } \\
\text { making separating } \\
\text { lane) }\end{array}$ & $\begin{array}{l}\text { Low } \\
\text { (Local } \\
\text { government will } \\
\text { buy the } \\
\text { paratransit that } \\
\text { has already } \\
\text { expired in } 10 \\
\text { years; still } \\
\text { conflict exists } \\
\text { with paratransit } \\
\text { owners } \\
\text { regarding track } \\
\text { intersection) }\end{array}$ & $\begin{array}{l}\text { Moderate } \\
\text { (There is an } \\
\text { opportunity to } \\
\text { combine different } \\
\text { type of } \\
\text { instruments such } \\
\text { as school bus, } \\
\text { NMT programs) }\end{array}$ & $\begin{array}{l}\text { Low } \\
\text { (The strategy still } \\
\text { not fully follow } \\
\text { the rule of Bus } \\
\text { Rapid Transit; } \\
\text { Almost the same } \\
\text { with DAMRI) }\end{array}$ \\
\hline Paratransit & $\begin{array}{l}\text { Low } \\
\text { (Local level makes } \\
\text { some exclusion to } \\
\text { paratransit; the } \\
\text { strategy has also to } \\
\text { involve energy } \\
\text { efficiency and } \\
\text { livelihood strategy) }\end{array}$ & $\begin{array}{l}\text { Low } \\
\text { (The incentive } \\
\text { for private } \\
\text { owner vehicles } \\
\text { (LCGC programs) } \\
\text { and neglected } \\
\text { the paratransit } \\
\text { driver as the } \\
\text { weak actors) }\end{array}$ & $\begin{array}{l}\text { Low } \\
\text { (Not flexible; } \\
\text { some } \\
\text { programmes } \\
\text { based on central } \\
\text { government } \\
\text { authorities to } \\
\text { encourage the use } \\
\text { of private } \\
\text { vehicles) }\end{array}$ & $\begin{array}{l}\text { Low } \\
\text { (vehicle age } \\
\text { restriction and } \\
\text { validity test not } \\
\text { effectively } \\
\text { implemented) }\end{array}$ \\
\hline Assessed as: & Low to moderate & Low to moderate & Low to moderate & Low / Restricted \\
\hline
\end{tabular}

Noted: green colour means 'moderate'; red colour means 'low' 


\subsection{Responsibilities and Resources}

Responsibilities are definitely delegated across all levels. In the transport sector, the central government has more budgets and qualified resources (human capital). Provincial levels and local levels have limited budgets but hold responsibility for their budgets. However, they are given sufficient facilities and resources by central government, sometimes without the need for mechanisms to control and monitor. For TMB, buses were provided by the central government, but proved unsuitable for the characteristics of the city, e.g. small roads and short road pattern are not suitable for bigger buses. Flexibility of resources allocations here are not clear. This means local authorities can only accept what has been given by the central government.

After a few months of implementation, most TMB vehicles were in poor condition (Sindo, 2013; Kompas, 2015) and management was aware. In 2015, TMB corridors had been built. The corridors that still exist are corridor I (Cibiru road - Soekarno-Hatta - Elang), corridor III (Ujung Berung Surapati - Dr. Djunjunan), and corridor IV (Cibeureum - Cicaheum). In the near future, eleven corridors will be able to operate. Vehicle operating time for all corridors is between 05.00-20.00 WIB. However, shelters are still not appropriate, unmanaged and mostly unused (Kartika, 2015). The present conditions show that the corridors are still the same and the facilities are not well maintained.

Effective mechanisms to manage transportation exist under Law 23/2014. This law aims to accelerate public welfare through the efficient and effective implementation of local governance. Under this law, the relationship between the central government, provincial-level, and local government are organised by their affairs. Here, environmental management for the transportation sector is obligatory for all levels of government. This law manages the relationship between levels and every region has their own responsibilities to perform their tasks.

Provincial stakeholders acknowledge that they have different responsibilities in managing resources. Therefore, if a city mitigation activity takes place, there will be the local responsibilities to tackle the problems. Collaborations between regional and local levels are frequently performed, especially for the emission test and environmental management, such as Adipura and CFD. However, for TMB, this collaboration does not exist. Lessons from Palembang City (South Sumatera) for BRT found the provincial level took full responsibilities to collaborate with local levels. Thus, the integration of BRT mode was not only available for the communities in the urban area, but also could be connected to the urban fringes (Jaeger et al., 2015; Jaeger, Nugroho, Zusman, Nakano, \& Daggy, 2014).

The empirical study shows that actors' involvement depends on their interest in the issue and their power basis. Only a few actors in the transport sector have a high interest (Ministry of Transportation, Local Transport Department, and Local EMA). Collaboration only exists at the national and provincial levels, as mentioned in the aims of RAN-GRK. Local governments can decide themselves their activities according to their specific abilities and conditions (see Table 3.4 that presents an overview of the key stakeholders of climate change mitigation and air quality improvement as explained in previous chapter 3 , section 3.4.2.3) 
It is too early to state whether climate change mitigation via TMB is on the right track. Experience of TMB implementation shows local governance is fixated on the city. The city budget is used according to the vision, mission and promises of the elected mayor. The limits of local governments in the provision of a budget to expand the services need support from all levels. Collaboration and transparency of resources, especially budget from the central government, could lead to a higher level of acceptance and recognition by the local level. The assessment result for responsibilities and resources aspects is described in Table 4.9.

Table 4.9: Assessment results for responsibilities and resources. Source: Collected data and interview analysis

\begin{tabular}{|c|c|c|c|c|}
\hline \multirow{2}{*}{$\begin{array}{l}\text { Responsibilities } \\
\text { and resources }\end{array}$} & \multicolumn{4}{|c|}{ Qualities of governance regimes } \\
\hline & Extent & Coherence & Flexibility & Intensity \\
\hline $\begin{array}{l}\text { Emission } \\
\text { measurement }\end{array}$ & $\begin{array}{l}\text { Moderate } \\
\text { (Not all } \\
\text { responsibility is } \\
\text { clearly assigned } \\
\text { and measurement } \\
\text { is only related to } \\
\text { local problems / } \\
\text { co-benefits) }\end{array}$ & $\begin{array}{l}\text { Moderate } \\
\text { (Local government } \\
\text { is struggling with } \\
\text { the emission } \\
\text { inventory for } \\
\text { primary data) }\end{array}$ & $\begin{array}{l}\text { Low } \\
\text { (Inflexibility to } \\
\text { pool resources) }\end{array}$ & $\begin{array}{l}\text { Low } \\
\text { (There has } \\
\text { allocated } \\
\text { resources from } \\
\text { other actors) }\end{array}$ \\
\hline $\begin{array}{ll}\text { Trans } & \text { Metro } \\
\text { Bandung } & \end{array}$ & $\begin{array}{l}\text { Low } \\
\text { (The source of } \\
\text { resources is mostly } \\
\text { from local level; } \\
\text { the central } \\
\text { government part is } \\
\text { only on the initial } \\
\text { of the program) }\end{array}$ & $\begin{array}{l}\text { Moderate } \\
\text { (To reduce the } \\
\text { conflict with other } \\
\text { public transport } \\
\text { and join the } \\
\text { cooperation within } \\
\text { other public } \\
\text { transport) }\end{array}$ & $\begin{array}{l}\text { Moderate } \\
\text { (The co- } \\
\text { investment } \\
\text { programme } \\
\text { existed in TMB) }\end{array}$ & $\begin{array}{l}\text { Low } \\
\text { (The imbalance } \\
\text { in resources has } \\
\text { to be used } \\
\text { optimally) }\end{array}$ \\
\hline Paratransit & $\begin{array}{l}\text { Low } \\
\text { (Lack of resources } \\
\text { to manage the } \\
\text { paratransit) }\end{array}$ & $\begin{array}{l}\text { Low } \\
\text { (There is } \\
\text { interdependency } \\
\text { among the actors } \\
\text { but it needs } \\
\text { improvement) }\end{array}$ & $\begin{array}{l}\text { Low } \\
\text { (Flexibility to } \\
\text { pool resources; } \\
\text { however, with } \\
\text { the precaution } \\
\text { principles) }\end{array}$ & $\begin{array}{l}\text { Low } \\
\text { (The allocated } \\
\text { resources are } \\
\text { not sufficient to } \\
\text { implement the } \\
\text { monitoring of } \\
\text { prerequisite as } \\
\text { stipulated) }\end{array}$ \\
\hline Assessed as: & Low to moderate & Low to moderate & $\begin{array}{l}\text { Low to } \\
\text { moderate }\end{array}$ & Low / Restricted \\
\hline
\end{tabular}

Noted: green colour means 'moderate'; red colour means 'low'

\subsection{Summary of Findings}

From three consecutive programmes, only two (emission measurement and TMB) have involved multiple levels and scales. Only paratransit is managed at the local level. The results of the quality of governance regimes from all programmes have contributed to the environment, social justice, 
and economic activities. However, the quantities of those programmes to lower GHG emissions still require further research.

Emission measurements only test emissions of private and public vehicles as stated in the programmes. The aim is to encourage vehicles users to improve vehicle performance and attain compliance with the standard as set by the rules. It has already been acknowledged that energy efficiency for road transport benefits not only transport efficiency and air quality, but climate considerations, as well (ADB, 2006; Bigazzi, 2011). In general, the emission test was perceived as business of a common programme enacted by the central government. Table 4.10a shows the analysis of the problem definition and goal statement aspects and the strategies and instruments with results as low to moderate. This can be explained as current programmes do not explore, develop and create a strategy for maintaining vehicles in good condition allowing them to give benefit to the environment. The programmes should incorporate local problems into the climate change mitigation as the global problems.

Local government owns the TMB public transport in Bandung City. The corridor service it offers intersects with other modes, such as paratransits and DAMRI. The use of BRT could benefit GHG emission reduction if these vehicles were energy efficient and standardised by government. Increasing the paratransit passenger load more than the paratransit would have the environmental effect of lower GHG emissions. However, in a governance context, TMB has to improve the level of service. From the five elements of governance (see Table 4.10b), the three elements of (1) the actors and networks, (2) problem definitions and goals, and (3) strategies and instruments, have lower quality. Lots of actors in public transport services make competition between the transport modes more difficult. There is a need for the implementing actors to reassess their goals and to improve their strategies to increase the service levels. Extended service time, dependable services (continuous), and separated lanes should become priorities by these actors.

The context of public transport finds that the approach to paratransits is restrictive and contrary to the TMB. The paratransit has low qualities of governance context (see Table 4.10c). Help from the provincial and state level is needed to maintain paratransits with the opportunity to play a role in reducing GHG emissions, especially by conducting eco-driving, conversion to gas fuel and maintaining optimal paratransit operations. The strategy to separate the niche from the TMB or DAMRI should be a solution to the sustainability of these modes of transportation. The expanded growth of online business transport (Grab and GO-JEK) needs to be anticipated by improving the level of services, while waiting for a new rule (law) that regulates fair competition for the public transport sector. 
Table 4.10: Qualities of governance from policies instruments.

Source: Collected data and interview analysis

a. Emission measurement context

\begin{tabular}{|c|c|c|c|c|}
\hline \multirow{2}{*}{$\begin{array}{l}\text { Emission } \\
\text { measurement }\end{array}$} & \multicolumn{4}{|c|}{ Qualities of governance regimes } \\
\hline & Extent & Coherence & Flexibility & Intensity \\
\hline Level \& scales & $\begin{array}{l}\text { Moderate } \\
\text { (All levels deal } \\
\text { with this issue) }\end{array}$ & $\begin{array}{l}\text { Moderate } \\
\text { (Only two levels } \\
\text { work together; } \\
\text { some of the } \\
\text { funding is from } \\
\text { central levels } \\
\text { and trusted to } \\
\text { the provincial } \\
\text { levels) }\end{array}$ & $\begin{array}{l}\text { Low } \\
\text { (It is hard to do } \\
\text { downscaling or up- } \\
\text { scaling) }\end{array}$ & $\begin{array}{l}\text { Moderate } \\
\text { (The central } \\
\text { government has } \\
\text { the power to } \\
\text { stop the funding) }\end{array}$ \\
\hline Actors \& networks & $\begin{array}{l}\text { Moderate } \\
\text { (Almost all } \\
\text { relevant actors } \\
\text { engage in } \\
\text { activities } \\
\text { including } \\
\text { association } \\
\text { workshop, } \\
\text { government in all } \\
\text { levels) }\end{array}$ & $\begin{array}{l}\text { Moderate } \\
\text { (They have the } \\
\text { standard } \\
\text { procedure and } \\
\text { it is already } \\
\text { established) }\end{array}$ & $\begin{array}{l}\text { Low } \\
\text { (It is hard to do } \\
\text { downscaling or up- } \\
\text { scaling) }\end{array}$ & $\begin{array}{l}\text { Moderate } \\
\text { (There is no } \\
\text { strong urge from } \\
\text { Ministry or West } \\
\text { Java EMA to } \\
\text { push the Local } \\
\text { Transport } \\
\text { Department or } \\
\text { Local EMA to } \\
\text { conduct the } \\
\text { measurement) }\end{array}$ \\
\hline $\begin{array}{l}\text { Problem } \\
\text { perspectives and } \\
\text { goal ambitions }\end{array}$ & $\begin{array}{l}\text { Low } \\
\text { (The various } \\
\text { problems that } \\
\text { have to be } \\
\text { addressed in local } \\
\text { level increases } \\
\text { due to additional } \\
\text { programmes from } \\
\text { the central } \\
\text { government) }\end{array}$ & $\begin{array}{l}\text { Moderate } \\
\text { (All levels do } \\
\text { not conflict with } \\
\text { each other in } \\
\text { terms of the } \\
\text { monitoring) }\end{array}$ & $\begin{array}{l}\text { Low } \\
\text { (It is hard to do } \\
\text { downscaling or up- } \\
\text { scaling) }\end{array}$ & $\begin{array}{l}\text { Low } \\
\text { (Different } \\
\text { perspective of } \\
\text { goals from each } \\
\text { level) }\end{array}$ \\
\hline $\begin{array}{l}\text { Strategies and } \\
\text { instruments }\end{array}$ & $\begin{array}{l}\text { Moderate } \\
\text { (Not all strategies } \\
\text { are implemented, } \\
\text { measurement is } \\
\text { only estimated } \\
\text { based on traffic } \\
\text { counting and air } \\
\text { pollution; other } \\
\text { strategies that } \\
\text { need further }\end{array}$ & $\begin{array}{l}\text { Moderate } \\
\text { (They have the } \\
\text { standard } \\
\text { procedure and } \\
\text { it is already } \\
\text { established) }\end{array}$ & $\begin{array}{l}\text { Low } \\
\text { (It is possible to } \\
\text { combine the } \\
\text { emission } \\
\text { measurement, } \\
\text { however there still } \\
\text { a problem with the } \\
\text { cross-sectoral issue) }\end{array}$ & $\begin{array}{l}\text { Low } \\
\text { (Central } \\
\text { government has } \\
\text { the power to } \\
\text { change the } \\
\text { system and to } \\
\text { facilitate this } \\
\text { measurement) }\end{array}$ \\
\hline
\end{tabular}




\begin{tabular}{|c|c|c|c|c|}
\hline \multirow{2}{*}{$\begin{array}{l}\text { Emission } \\
\text { measurement }\end{array}$} & \multicolumn{4}{|c|}{ Qualities of governance regimes } \\
\hline & Extent & Coherence & Flexibility & Intensity \\
\hline & $\begin{array}{l}\text { collaboration are } \\
\text { still disregarded) }\end{array}$ & & & \\
\hline $\begin{array}{l}\text { Responsibilities } \\
\text { and resources }\end{array}$ & $\begin{array}{l}\text { Moderate } \\
\text { (Not all } \\
\text { responsibilities } \\
\text { are clearly } \\
\text { assigned and } \\
\text { measurement is } \\
\text { only related to } \\
\text { local problems / } \\
\text { co-benefits) }\end{array}$ & $\begin{array}{l}\text { Moderate } \\
\text { (Local } \\
\text { government } \\
\text { struggle with } \\
\text { the emission } \\
\text { inventory for } \\
\text { primary data) }\end{array}$ & $\begin{array}{l}\text { Low } \\
\text { (Inflexibility to pool } \\
\text { resources) }\end{array}$ & $\begin{array}{l}\text { Low } \\
\text { (There has } \\
\text { allocated } \\
\text { resources from } \\
\text { other actors) }\end{array}$ \\
\hline
\end{tabular}

Noted: green colour means 'moderate'; red colour means 'low'

\section{b. Trans Metro Bandung context}

\begin{tabular}{|c|c|c|c|c|}
\hline \multirow{2}{*}{$\begin{array}{ll}\text { Trans } & \text { Metro } \\
\text { Bandung } & \end{array}$} & \multicolumn{4}{|c|}{ Qualities of governance regimes } \\
\hline & Extent & Coherence & Flexibility & Intensity \\
\hline Level \& scales & $\begin{array}{l}\text { Moderate } \\
\text { (Only central } \\
\text { government and } \\
\text { local level are } \\
\text { involved) }\end{array}$ & $\begin{array}{l}\text { Low } \\
\text { (Mutual } \\
\text { dependence is } \\
\text { indicated by bus } \\
\text { provision from } \\
\text { the central } \\
\text { government; } \\
\text { provincial level } \\
\text { did not interfere) }\end{array}$ & $\begin{array}{l}\text { Low } \\
\text { (It is not possible } \\
\text { to give the } \\
\text { flexibility for } \\
\text { local level to } \\
\text { provide their } \\
\text { facilities) }\end{array}$ & $\begin{array}{l}\text { Moderate } \\
\text { (Central } \\
\text { government has } \\
\text { the power to halt } \\
\text { the resources) }\end{array}$ \\
\hline Actors \& Networks & $\begin{array}{l}\text { Low } \\
\text { (Only the central } \\
\text { government and } \\
\text { the local level are } \\
\text { involved, other } \\
\text { actors } \\
\text { (paratransit } \\
\text { driver and users) } \\
\text { are rarely } \\
\text { engaged), other } \\
\text { institution, such } \\
\text { as Public Works, } \\
\text { rarely involved by } \\
\text { transport } \\
\text { department }\end{array}$ & $\begin{array}{l}\text { Low } \\
\text { (Interaction } \\
\text { strength is low; } \\
\text { the operation is } \\
\text { sometimes } \\
\text { halted) }\end{array}$ & $\begin{array}{l}\text { Low } \\
\text { (It is not possible } \\
\text { to give the } \\
\text { flexibility for } \\
\text { local level to } \\
\text { provide their } \\
\text { facilities) }\end{array}$ & $\begin{array}{l}\text { Moderate } \\
\text { (Local government } \\
\text { has the power to } \\
\text { halt. In some } \\
\text { occasion, it is } \\
\text { halted by } \\
\text { paratransit) }\end{array}$ \\
\hline
\end{tabular}




\begin{tabular}{|c|c|c|c|c|}
\hline \multirow{2}{*}{$\begin{array}{ll}\text { Trans } & \text { Metro } \\
\text { Bandung } & \end{array}$} & \multicolumn{4}{|c|}{ Qualities of governance regimes } \\
\hline & Extent & Coherence & Flexibility & Intensity \\
\hline $\begin{array}{l}\text { Problem } \\
\text { perspectives and } \\
\text { goal ambitions }\end{array}$ & $\begin{array}{l}\text { Low } \\
\text { (Local level with } \\
\text { the small } \\
\text { resources has to } \\
\text { deal with various } \\
\text { problems that } \\
\text { occurs in the } \\
\text { field) }\end{array}$ & $\begin{array}{l}\text { Low } \\
\text { (There are } \\
\text { competitions } \\
\text { between public } \\
\text { transport mode. } \\
\text { There is also } \\
\text { other } \\
\text { competition } \\
\text { between } \\
\text { transport } \\
\text { department with } \\
\text { other } \\
\text { department such } \\
\text { as Public works, } \\
\text { Spatial plan) }\end{array}$ & $\begin{array}{l}\text { Low } \\
\text { (It is possible to } \\
\text { re-assess goal, } \\
\text { however } \\
\text { concerning the } \\
\text { sector } \\
\text { perspective, it is } \\
\text { hard to be } \\
\text { carried out) }\end{array}$ & $\begin{array}{l}\text { Moderate } \\
\text { (Transport } \\
\text { department has } \\
\text { different goals } \\
\text { regarding climate } \\
\text { change mitigation, } \\
\text { however } \\
\text { encourage TMB } \\
\text { development) }\end{array}$ \\
\hline $\begin{array}{ll}\text { Strategies and } \\
\text { instruments }\end{array}$ & $\begin{array}{l}\text { Low } \\
\text { (Policy strategy to } \\
\text { convert the } \\
\text { paratransit into } \\
\text { bus; there are } \\
\text { still no progress } \\
\text { in building } \\
\text { separate lane for } \\
\text { TMB and } \\
\text { corridors } \\
\text { development) }\end{array}$ & $\begin{array}{l}\text { Low } \\
\text { (Local level will } \\
\text { buy the } \\
\text { paratransit that } \\
\text { has already } \\
\text { expired in } 10 \\
\text { years; still } \\
\text { conflict with } \\
\text { paratransit } \\
\text { owner regarding } \\
\text { route } \\
\text { intersection) }\end{array}$ & $\begin{array}{l}\text { Moderate } \\
\text { (There are } \\
\text { opportunities to } \\
\text { combine } \\
\text { different type of } \\
\text { instruments such } \\
\text { as school bus, } \\
\text { NMT programs) }\end{array}$ & $\begin{array}{l}\text { Low } \\
\text { (The strategies } \\
\text { still do not fully } \\
\text { follow the rule of } \\
\text { Bus Rapid Transit; } \\
\text { Almost the same } \\
\text { with DAMRI) }\end{array}$ \\
\hline $\begin{array}{l}\text { Responsibilities } \\
\text { and resources }\end{array}$ & $\begin{array}{l}\text { Low } \\
\text { (The source of } \\
\text { resources is } \\
\text { mostly from local } \\
\text { level; the central } \\
\text { government only } \\
\text { support the initial } \\
\text { part of the } \\
\text { program) }\end{array}$ & $\begin{array}{l}\text { Moderate } \\
\text { (To reduce the } \\
\text { conflict with } \\
\text { other public } \\
\text { transport, join } \\
\text { the cooperation } \\
\text { within other } \\
\text { public transport) }\end{array}$ & $\begin{array}{l}\text { Moderate } \\
\text { (The co- } \\
\text { investment } \\
\text { programme } \\
\text { exists in TMB) }\end{array}$ & $\begin{array}{l}\text { Low } \\
\text { (The imbalance in } \\
\text { resources has to } \\
\text { used optimally) }\end{array}$ \\
\hline
\end{tabular}

Noted: green colour means 'moderate'; red colour means 'low' 
c. Paratransit context.

\begin{tabular}{|c|c|c|c|c|}
\hline \multirow[t]{2}{*}{ Paratransit } & \multicolumn{4}{|c|}{ Qualities of governance regimes } \\
\hline & Extent & Coherence & Flexibility & Intensity \\
\hline Level \& scales & $\begin{array}{l}\text { Low } \\
\text { (Only local levels } \\
\text { are involved) }\end{array}$ & $\begin{array}{l}\text { Low } \\
\text { (Only local levels } \\
\text { are involved) }\end{array}$ & $\begin{array}{l}\text { Low } \\
\text { (Not flexible; } \\
\text { based on } \\
\text { administrative } \\
\text { level) }\end{array}$ & $\begin{array}{l}\text { Low } \\
\text { (Only the local } \\
\text { government has } \\
\text { to do with their } \\
\text { programs) }\end{array}$ \\
\hline Actors \& networks & $\begin{array}{l}\text { Low } \\
\text { (Only the local } \\
\text { government and } \\
\text { association are } \\
\text { involved) }\end{array}$ & $\begin{array}{l}\text { Moderate } \\
\text { (On some } \\
\text { occasion, the } \\
\text { paratransit } \\
\text { protested the } \\
\text { TMB operation) }\end{array}$ & $\begin{array}{l}\text { Low } \\
\text { (Not flexible; } \\
\text { based on } \\
\text { administrative } \\
\text { level) }\end{array}$ & $\begin{array}{l}\text { Low } \\
\text { (Local } \\
\text { government } \\
\text { worked based on } \\
\text { their program) }\end{array}$ \\
\hline $\begin{array}{l}\text { Problem } \\
\text { perspectives and } \\
\text { goal ambitions }\end{array}$ & $\begin{array}{l}\text { Low } \\
\text { (Only the local } \\
\text { government has } \\
\text { to deal with } \\
\text { association, } \\
\text { drivers, users; } \\
\text { However, because } \\
\text { of the } \\
\text { developments of } \\
\text { online application- } \\
\text { based } \\
\text { transportation } \\
\text { services, the } \\
\text { provincial level } \\
\text { have more } \\
\text { influence to settle } \\
\text { this issue) }\end{array}$ & $\begin{array}{l}\text { Low } \\
\text { (Contradictive } \\
\text { with TMB goals) }\end{array}$ & $\begin{array}{l}\text { Low } \\
\text { (re-assessment } \\
\text { goals are based } \\
\text { on resources } \\
\text { availability from } \\
\text { the local } \\
\text { government) }\end{array}$ & $\begin{array}{l}\text { Low } \\
\text { (Local } \\
\text { government has } \\
\text { the aim to } \\
\text { diminish the use } \\
\text { of the } \\
\text { paratransit) }\end{array}$ \\
\hline $\begin{array}{l}\text { Strategies and } \\
\text { instruments }\end{array}$ & $\begin{array}{l}\text { Low } \\
\text { (Local level makes } \\
\text { some excluded to } \\
\text { paratransit; the } \\
\text { strategy has also } \\
\text { to consider energy } \\
\text { efficiency of the } \\
\text { vehicles and } \\
\text { livelihood strategy } \\
\text { of the drivers) }\end{array}$ & $\begin{array}{l}\text { Low } \\
\text { (The incentive for } \\
\text { private owner } \\
\text { vehicles (LCGC } \\
\text { programs) } \\
\text { neglected the } \\
\text { paratransit driver } \\
\text { as the weak } \\
\text { actors) }\end{array}$ & $\begin{array}{l}\text { Low } \\
\text { (Not flexible; } \\
\text { some } \\
\text { programmes are } \\
\text { based on central } \\
\text { government } \\
\text { authorities to } \\
\text { encourage the } \\
\text { use of private } \\
\text { vehicles }\end{array}$ & $\begin{array}{l}\text { Low } \\
\text { (Age restriction } \\
\text { and validity test } \\
\text { for vehicles are } \\
\text { not effectively } \\
\text { implemented) }\end{array}$ \\
\hline $\begin{array}{l}\text { Responsibilities } \\
\text { and resources }\end{array}$ & $\begin{array}{l}\text { Low } \\
\text { (Lack of resources } \\
\text { to manage the } \\
\text { paratransit) }\end{array}$ & $\begin{array}{l}\text { Low } \\
\text { (There is } \\
\text { interdependency } \\
\text { between the } \\
\text { actors but it } \\
\text { needs } \\
\text { improvement) }\end{array}$ & $\begin{array}{l}\text { Low } \\
\text { (Flexibility to } \\
\text { pool resources; } \\
\text { however, with } \\
\text { the precaution } \\
\text { principles) }\end{array}$ & $\begin{array}{l}\text { Low } \\
\text { (The allocated } \\
\text { resources are not } \\
\text { sufficient to } \\
\text { implement the } \\
\text { monitoring of } \\
\text { prerequisite as } \\
\text { stipulated) }\end{array}$ \\
\hline
\end{tabular}

Noted: green colour means 'moderate'; red colour means 'low' 


\subsection{Conclusions}

The analysis of government dimensions and quality of governance has shown that all programmes support climate change mitigation, as mentioned in the RAD-GRK. The extent aspect was found to be low to moderate; flexibility as restrictive; and, coherence and intensity as moderate. In general, this creates a context with limits, although several improvements have shown a positive trend at the local level.

The governance assessment of climate change mitigation programmes, as perceived by the actors, concluded that the problem and goal challenges were faced in all cases. Different actor perspectives often complicated the development of operational programmes. For instance, the progress of public transport would sustain and improve continuously, if the goals and perspectives of the actors were better aligned. For all actors to understand and acknowledge each other's problems would help solve problems and eliminate resistance amongst the parties. Until now, the problem has arisen from rapid development of online transportation, which cannot be anticipated by all stakeholders. A similar condition occurs in the emission measurement programme, which needs to acknowledge goals beyond the present situation and that solve local and global problems. Governance is seen as needing to operate "beyond the government" and, thereby, provide a wider context for decision-making and implementation (Bressers \& Kuks, 2003). The GAT helps all parties to look at which elements of governance have to be strengthened to achieve better outcomes.

Practical lessons derive from this analysis in the complex situation of managing structural issues, as well as the core qualities of governance. There is no panacea to tackling the problems that exist in all cases .... "Practitioners and scholars who fall into panacea traps falsely assume that all problems of resource governance can be represented by a small set of simple models, because they falsely perceive that the preferences and perceptions of most resource users are the same" (Ostrom, Janssen, \& Anderies, 2007). Therefore, empowering the local level, through decentralisation as a way to democratise and attain better public governance should not be viewed as a panacea. Sometimes, this approach will simply reinforce the power and influence of the elites at the local level (United Nations, 2007, p. 11). It also stated that "sustainability as the fundamental value of the sustainable urban transport that seen as a panacea for environmental problems has lacked its insight on how and when to implement this concept" (Owens, 2008).

This chapter has shown local levels neglected paratransit programming. The role of multi-levels and actors were often more relevant to other programmes (emission test and TMB) than those who perceived the programme as achieving lower GHG emissions.

The next chapter will describe the specific case of paratransit and explain why and how the other actors (private vehicle users) were reluctant to use public transport, such as paratransit and TMB. This will address the research question on the perspective of private vehicle users towards climate change mitigation and tackling local problems (as will be explained further in Chapter 7). 


\section{Chapter 5: Paratransit as a Mode of Public Transport}

\subsection{Introduction}

Bandung is one urban city that mostly uses a road-based transportation as its public transport service. This uses informally supplied small vehicle transport services, as described in the World Bank report (Gwilliam, 2002) or otherwise referred to as paratransit services. Paratransit is described as informal, intermediate or unconventional public transport (Iles, 2005, p. 30). It is widely used in Asian developing cities, including those in Indonesia. In this thesis, the paratransit in Bandung City is a motorised public transport for passengers, such as cars or minibuses that have existed for a long time in urban Indonesia. These vehicles have a capacity of 12-14 passengers with normal size and use modified seats facing each other in addition to the driver ${ }^{38}$.

Paratransit 'angkutan kota' or abbreviated as 'angkot' is widely known as an important public transport mode in developing cities in Asia (Cervero \& Golub, 2007; Joewono \& Kubota, 2008). They evolved because of a lack of mass transit systems (Cervero \& Golub, 2007; Tarigan et al., 2014). However, they survives even with few policies intervention and no investment or subsidy from government (Tri Basuki Joewono \& Hisashi Kubota, 2007).

Paratransits could help reduce GHG emissions and they are widespread in Asia. Studies have been conducted since the 1990s. Cervero (1991) compares urban paratransit modes in several cities (Jakarta, Surabaya, Medan, Bandung (Indonesia), Bangkok (Thailand), Manila (Philippines), and Kuala Lumpur (Malaysia). They use poor roads and offer co-benefits to poor people, profit to their owners and operators (drivers) and create a unique market. However, research also found a diminishing role over time with the increase of privately owned vehicles.

Wicaksono et al. (2015) studied paratransit in six Asian countries and discussed the legal condition and intermodal issues. The research showed that, in many cases, there were issues of restructuring existing public transport to migrate into Bus Rapid Transit (BRT). However, some cases showed paratransit modes responded well to travel demand and sustained if vehicle size was minimised. Phun, Lim, \& Yai, (2015) reviewed the paratransit literature in Asian, including definitions, characteristics, and sustainability. There have been some thoughts about using paratransit to reduce air pollution by using electric vehicles, as revealed from a survey in Phnom Penh (Phun et al., 2015). However, none of the studies showed the prospect of paratransit as a tool to mitigate climate change.

A study in Bandung City considered co-benefits action plan for Bandung City from IGES (Institute for Global Environmental Strategies) in 2016. From eleven alternative programmes, three programmes had high contributions to co-benefits, namely eco-driving, pedestrian and nonmotorised programme, and also paratransit revitalisation programme (Nugroho, 2016).

\footnotetext{
${ }^{38}$ Transportation Minister Decree no. 35/2003
} 
How is the condition of Bandung paratransit in reality? As privately owned vehicles, these public transports are bounded by the rules set by the government. The number of urban transports on each route in Bandung City will remain the same ${ }^{39}$. However, this condition is far from reality. Many vehicles exceed their age limit, but still exist and pick up passengers. This is coupled with the decrease of the load factor of passengers in Bandung City (Aviasti, Rukmana, \& Jamaludin, 2016; Dinas Perhubungan, 2012).

A performance report published by Local Transportation Department found strategic issues in Bandung City involving public transport services low performance (both quality and quantity) and a lack of management of paratransit enterprises. Several programmes have been created to increase paratransit performance. Results have been far below expectations (Dinas Perhubungan, 2015). Other programmes to encourage the quality of public transport in the form of buses, such as TMB and Trans Bandung Raya (DAMRI) are, in fact, reducing paratransit revenue ${ }^{40}$ and have become sources of conflict.

This chapter shows how the governance of paratransit as a public transport operates in Bandung City. Using Contextual Interaction Theory, we analysed co-benefits and readiness to reduce GHGs. Besides $\mathrm{CIT}$, user perception was surveyed to complement the report (as is statistically reported in Chapter 7).

\subsection{Governance of Paratransit}

There is an intricate pattern in the divide between government's purposes and its attainments. Even the paratransit programme initially was not intended to reduce GHG emissions. However, the use of paratransits, according to research, co-benefits local government by its positive contribution to lower GHG emissions and in attempts to revitalise the urban transport (Nugroho, 2016). Shifting cars to public transportation and non-motorised transport in cities was also of crucial importance to lowering GHGs emissions from transportation systems (ADB, 2006; Schiller et al., 2010).

The local government plan to reduce GHG emissions uses a vehicle age restriction alongside a feasibility test, eco-driving, and low carbon fuels (such as using gas fuel). Paratransits in Bandung have around 5,521 vehicles on 36 routes $^{41}$. However, the number of paratransit vehicles is decreasing given the reduced profits. The representative of Indonesian Transport Workers Union (FSPTI) informed that only about $30 \%$ of angkot were still active (Sutrisno, 2017), although many paratransit vehicles officially expired still get passengers. We analyse the governance of paratransit to lower GHG emissions using the GAT that derives from CIT (Bressers et al., 2013).

\footnotetext{
${ }^{39}$ Operational age restriction in accordance with article 89, Bandung regulation no 16/2012

${ }^{40}$ Based on interviews with paratransit cooperation, owners, and drivers (2016)

${ }^{41}$ Based on Major Decree No. 551/Kep.055-Huk/2008
} 


\subsubsection{Levels \& Scales}

Bandung City is a core area of national activity with a high travel demand. Development of the Bandung Metropolitan Areas (BMA) has to aim to improve living standards whilst also facing a growing number of households and more private vehicle purchasing. This is coupled also with the development of a highway to connect Jakarta (as the national capital) to Bandung (the Cipularang Toll road has operated since 2004) which also adds to the transportation problems of the City.

The paratransit public transport evolved after the abolition of motorised tricycle vehicles (called 'bemo' - a short form of becak motor) in the early 1980s (Perambahan, 2009). This tricycle was banned as being out-dated, not meeting safety standards, and a source of air pollution. However, this tricycle still exists in limited number in some parts of Jakarta (Utomo, 2017).

Spatially (Cash et al., 2006), Bandung City, along with four other adjacent cities and municipalities ${ }^{42}$, is located in Bandung Basin. This basin has high human-environmental interactions and is viewed as an ecological landscape area that suffers from a deterioration of air quality associated with transport and trans-boundary pollution (Setiawan, Arwin, \& Maria, 2006). The cities and municipalities in the Bandung Basin region are the jurisdictions that will have to cooperate to reduce pollution sources, such as dealing with paratransit management. Such policy aims will not be achieved if cities in one basin have different policies for public transport, for example, vehicle age restriction through regulation.

Paratransit in Bandung does not come entirely from Bandung City, but also involves transport from other regencies and cities. Local government and operators that manage the paratransit in Bandung City have objected to the inclusion of paratransit from outside Bandung because they do not meet the age limit (10 years) and have different requirements. These differences will lead to non-fulfilment of preconditions, such as minimum service standards and the feasibility test. The provincial level has the authority to manage the restriction on vehicles entering the city using a trajectory permit. Local stakeholder analysis shows it should be a local level task to maintain urban transit in each region to a fixed number ${ }^{43}$. However, this issue, of other paratransits entering Bandung City, is hard to move up to the provincial level. The reason being is that it would almost certainly require a new terminal that would surely be charged to Bandung City.

\subsubsection{Actors \& Networks}

The legal and regulatory framework for paratransit in Indonesia is based on Law No. 22/2009 regarding traffic and road transport and clarified by Transportation Minister Decree No. 74/2014. The Governments (central, provincial, district or city) are required to meet travel needs by organising mass transit. Paratransit is a transportation mode that utilises public buses or

42 Bandung regency, West Bandung Regency, Cimahi City, and a part of Sumedang Regency (192.000 ha)

${ }^{43}$ In depth interviews with the manager of urban transport section and cooperatives on September 2016 
passenger cars confined to particular routes. However, the option to use paratransit provides vital mobility across Asia, and particularly cities. It has filled a gap arising from the lack of government public transport provisions and is used as an efficient feeder network (Joewono \& Kubota, 2008; Monzon \& Guerrero, 2004; Phun et al., 2015; Verma \& Ramanayya, 2014; Wicaksono et al., 2015). To date, the actors with merit in advancing urban transport are cooperatives, the route-unit supervisor $\left(\mathrm{KPU}^{44}\right)$ paratransit entrepreneurs and drivers.

In Bandung, the use of public bus niche is mixed with the use of paratransit. This condition provides a source of conflict in Bandung, especially when implementing new programmes, such as the opening of a new route for city buses (Trans Metro Bandung, Trans Bandung Raya, and School Bus). Bandung local government owns the TMB and School Bus. Trans Bandung Raya is operated by the state-owned enterprise, and private individuals own paratransit.

The Transport Department dominates the implementation of policy instruments in Bandung, in the programmes (School Bus and TMB). Local government is responsible for paratransit governance with dialogue that occurs generally after strikes by the paratransit drivers. Other actors (provincial or central government) do not interfere, although, some financial support is provided from central government for bus providers (TMB or Trans Bandung Raya).

Paratransit owners and drivers are impacted by the TMB programmes run by the Local Government. To date, the conversion of paratransit into the TMB has not occurred (three paratransit vehicles for one TMB vehicle) (Muttaqien, 2011; Putri, 2016). The plan to involve the relevant stakeholders, such as cooperatives, to share the programmes with the local government also has not yet been implemented, neither have drivers been hired. It is difficult to use local government budget to convert paratransit vehicles because it will handle a large number of paratransits. This illustrated by the cooperative from Kobanter Baru (New Kobanter) that holds 2,603 owners with 4,418 paratransit vehicle units with 38 trajectories. The new model of paratransit 'angklung' has been offered by local government to replace the paratransits that have exceeded their age limit. It is possible for the government to offer other actors, such as financial institutions, to provide competitive financing facilities.

\subsubsection{Problems Perspective}

The Transport Department has urged paratransits to meet their technical aspect and feasibility test required by the Minister of Transportation regulation. This requires paratransits, as the public transport in designated routes, to meet minimum service standards, namely: being safe, secure, comfortable, and affordable (Ministry regulation no 29/2015). A stipulation under the Road Traffic and Public Transport Act (Act no 22/2009) states that individuals cannot own paratransits; a public company, private company, or either legal organisation, such as cooperatives, must own them. In 2016, paratransit owners had to register their vehicles into the

\footnotetext{
${ }^{44}$ Representatives of the cooperatives at the routes
} 
legal organisation (Mauludi, 2016; Purnama, 2017; Radar Bangka, 2015). The transportation department also has programmes to encourage mass transportation, such as buses (TMB and Trans Bandung Raya). The programme developed by the Local Transport Department eventually resulted in a conflict with other public transports. The TMB has its own technical and operational unit in the structure of the Transportation Department. However, the paratransit has to cope with their limited resources and has to pay various bills (permits or vehicle purchase).

As a medium-sized enterprise, the paratransit owners have to pay off the costs of their vehicles. These actors are also charged to obtain several licenses, such as route permits that expires in every five years and that are equipped with a monitoring card (these expire every one year) and transportation business license (these expire every six months ${ }^{45}$ ). Vehicle owners have to follow many rules that often become obstacles. This is apart from their obligation to pay an instalment of their vehicles for their leasing. The cooperatives and the paratransit owners perceive that the obligation to pay their instalment become a major problem. Most vehicle owners obtain a loan from the leasing company with interest rates higher than those of the conventional banks. However, no owners obtain funds from banks; a condition paratransit owners and cooperatives complain about. They need government assistance to address this problem. The vehicle owners also have to pay other expenses, such as the cost of vehicles maintenance. The drivers have to pay the costs for vehicle tests and terminal payments ${ }^{46}$.

The local government has imposed a 10 -year validity period rule for urban transport vehicles (Bandung regulation no. 16/2012). The vehicles must be renewed, if they exceed this limit. The aim of this regulation, from a local government perspective, is to ensure vehicles meet the feasibility test and minimum service standard to ensure vehicles are performing well and can satisfy passengers.

Problems frequently occur when owners have to pay their mortgage. If owners cannot meet the agreement (usually in 5 years term loan), occasionally they would transfer the vehicles to another party. However, the common practice in Bandung is for car owners to not renew their paratransit vehicles, even though they have exceeded the specified time limit ${ }^{47}$. In this condition, the minimum service standard is not the main purpose of the vehicle owner. They have to earn the money to pay the monthly instalment. However, the rules do not apply equally. For example, most vehicles from other regions, such as Bandung Regency and Cimahi City, exceed the 10 year age limit of car production, but they are still operating and entering Bandung City (Republika, 2009; Wijanarko, 2014).

Drivers also have their own goals. Most public transport in Indonesia, such as bus, taxi or paratransit, use the renting system called 'setoran' system (Iles, 2005, p. 222; Sumarsono, 2014).

\footnotetext{
${ }^{45}$ Bandung regulation related to the implementation of transportation (Local regulation no. 10/2001)

${ }^{46}$ Bandung regulation related to retribution of transportation (Local regulation no. 16 year 2012)

${ }^{47}$ Based on interviews with cooperatives (Kobanter Baru and Kobutri), drivers and vehicle owners (October 2016)
} 
This system requires the driver and conductor to pay a sum of money as previously set by the paratransit owner or enterprises. The amount a driver should pay depends on the route and a vehicle's production year. Some routes have a higher load factor than others. The owner will ask for a higher deposit if the routes have higher load factor. However, on the same route, it is possible that the owner requests a lower deposit if a car is old. New engine became the main reason for owners to ask for higher deposits. A fuel injection system will be charged a higher deposit than a carburettor system. Thus, if the drivers want to earn enough money for a day, then they should be able to operate public transport as efficiently as possible.

Jakarta City has planned a pilot project to stop the renting system as drivers ignored the minimum service standard (Kartika, 2015). However, this condition is hard to implement in Bandung. "Jakarta and Bandung have different transportation systems. The fact that the mass rapid transport such as Trans Jakarta and Railway transportation system have already existed, it makes Jakarta much different from Bandung" based on transport expert from ITB (PRFM, 2015).

\subsubsection{Strategies and Instruments}

A strategy to intensify the minimum service standard exists using rerouting and re-pooling. There are some routes in Bandung City that have many passengers or high load factors, such as Margahayu - Ledeng, St. Hall - Gede Bage and Ciroyom - Cikudapateuh. This situation was revealed by the study to reroute paratransits conducted by the research and community services institution (LPPM ITB) at the request of the Bandung Transport Department. Certain routes have a relatively high load factor ${ }^{48}$ (more than 0.5 ) and also have appropriate numbers of paratransit. The load factor on St. Hall - Gede Bage has the highest rank (0.82), followed by Margahayu Ledeng (0.67) and Ciroyom - Cikudapateuh (0.61), respectively. However, the drivers said that conditions were immensely different from the past ${ }^{49}$ when people tended to use private vehicles, especially motorcycles.

The aim of rerouting paratransits was to manage the ideal route in Bandung City. This would benefit: (1) equitable distribution of income; (2) reduction of paratransit stop on streets to wait for passengers at a wrong place (called as 'ngetem') that could reduce congestion (Dinas Perhubungan, 2012, 2015). The programme would streamline the number of paratransit in accordance with the existing fleet (Dinas Perhubungan, 2012), whilst recognising that the demand for paratransits is very diverse across many areas. The programme has not been implemented on every route (Achmad, 2016), and the cooperatives have really appreciated the results of the study.

The transport department has observed that many paratransit operate on high demand routes that should be served by adequate numbers of paratransit. However, when deployed in practice many conflicts have occurred. The niche of paratransit is occupied, not only by urban transport

\footnotetext{
${ }^{48}$ The dimensionless ratio of demand (passengers) to the supply (paratransit seats)

${ }^{49}$ Based on the interviews with the driver at Ciroyom - Cikudapateuh route
} 
'angkot', but also other existing paratransit, such as 'ojeks' (motorcycle taxis), and also 'becaks' (human power tricycle transport). If urban transport operates to the centre of the network, it will intersect with other transport modes. After some of the plans were implemented, a number of incidents and conflicts have occurred. As a result, the paratransits have requested security guarantees from the Transportation Department to help ensure this new programme will operate according to plan.

Documents from the Local Environmental Management Agency (EMA), as the coordinator in terms of GHG and climate change, show several programmes for public transport initiated by the Transport Department. The proposed actions are: (1) increasing the down-payment of motorcycles and progressive tax of private vehicle; (2) renewal of paratransit; (3) providing financial support for renewal of the paratransit; (4) increasing the service quality of paratransit and its facility; (5) installing converter kit for paratransit urban transport; (6) emission check (BPLH, 2014).

The development of transportation, such as motorcycles, makes the paratransit business less promising and more difficult. The transport department acknowledges that changing current conditions needs an overview and higher authority, such as central government. Information disseminated by the Provincial Transport Department suggests there will be a domino effect by restricting the vehicles on investment, labour, and industries. Indonesia is a member of World Trade Organisation (WTO) and operates under its terms. As such, it will be complicated to restrict investment or production.

The programme to use urban transport on Friday (called 'Jumat Ngangkot') was inaugurated by Mayor Bandung and initiated by the Transport department. This programme tried to encourage the Bandung citizens to use public transport for at least one day a week. Another programme promoted the use of non-motorised transport, such as bicycles, was conducted every Thursday. The Transport Department organised a festival to echo these programmes. This targeted the bike community, students, and employees to use bicycles and paratransit. Various problems were encountered such as lack of bike paths, lack of bike storage facilities, and lack of safety aspects; complained arose from users and local community (bike to work).

The transport department tried to reduce the number of paratransits and provide bus transport services from the TMB owned by the Bandung Government. The local government had planned to convert the paratransit vehicles, but this was constrained by rules that restricted purchases of second-hand cars. To date, the plan to integrate the paratransits by government is not yet workable. The transport department at the provincial level felt that the authority to manage paratransits was in the hands of local government, but not with the upper-level authorities.

\subsubsection{Responsibilities and Resources}

As front-liners, paratransit drivers are the weakest party. They do not have the same bargaining power as the owners, especially when the owners raise the deposit (setoran) or sell their 
paratransit vehicles. The drivers do not have legal contracts for their job. They only have the power to protest if the routes are disturbed by other public transports. The negotiation to solve such conflict is commonly represented on their behalf by the cooperatives and the Transport Department. However, the cooperatives have no significant role to play in changing or adjusting routes. If the dispute resolution is reached, it does not affect the driver's income.

The route-unit supervisor (Kantor Pelayanan Umum or KPU) of the cooperatives has the responsibility to collect the payments. The payments requested by the cooperatives vary among the drivers depending on the cooperative's membership. The Kobanter Baru has requested lower payments than those of Kobutri or Kopamas. Besides the daily payments, the drivers also have to pay their membership contribution. The driver's contribution will be allocated by the KPU to help drivers, if a problem exists, such as the conflict with other public transports, passengers, or officers $^{50}$.

To maintain vehicles in good performance, the Transport Department conducts feasibility tests. Transport Department resources facilitate paratransits to meet the minimal service standard for vehicle testing. The motor vehicles testing centres involving can accommodate as many as 250 vehicles/day. The Transport Department has operated two instruments with additional facilities since 2013. The vehicles tests check emissions, lighting, brakes, vehicle weight, and other activities. The tests are conducted every six months. In addition, other programmes test vehicle emissions, including paratransits. The Local and Provincial Environmental Management Agency holds these. However, this test requires a follow-up, in terms of assistance for vehicle repair or provision of spare parts, so vehicle will meet the emission requirement ${ }^{51}$. To improve services, the cooperatives also conduct training for drivers with the help of the Transport Department.

Out of all the urban transport problems, the cooperatives feel that the development of motorcycle use is the most important issue they face, particularly as this reduces their income. This issue has been examined by the Transportation Department at the local level, provincial, and also ORGANDA (road transport organisation).

The role and responsibility of the Provincial level needs to be much improved for managing urban transport entering Bandung from other regions. Every level must be involved, as the problems cannot be handled just locally. Kobanter Baru is a cooperative located in Bandung. It always communicates with the local level. In particular cases, such as the recent issue of the ownership of urban transport requiring them to be a cooperative or legal entity, the provincial level was asked to give explanations.

\footnotetext{
${ }^{50}$ Based on the interviews with the drivers and paratransit owners on September 2016

${ }^{51}$ Based on the interviews with the paratransit owners on September 2015 and with the cooperatives and drivers on September 2016
} 


\subsection{The Resume of the Paratransit Governance}

The paratransit vehicles in Bandung City have different jurisdictional scales, e.g. various cities and municipalities in the Bandung Basin region. To conduct the climate policy, the paratransit programme at all levels has to cooperate in order to reduce the source of pollution and or to reduce GHG emissions. If each city has a different policy regarding public transport (paratransit), the aim of the overarching policy will not be achieved.

The paratransit mode has bolstered the low capacity of government to provide public transport in the city. There is an absence of actors (government) to regulate public transport activities in Bandung City. If the implementing actors have the capacity to extend other modes of transport, the approach should also provide the flexibility to other actors to cooperate and participate in developing alternative transport modes.

All actors acknowledge these problems hinder the development of paratransit. However, actors have translated the goals and means to tackle the problems differently. The root issues are paratransit actors' role (rights and obligations of drivers and owners) in maintaining excellent services when other actors who have the authority have responded to this less well. The paratransit drivers have become the backbone and the frontline guards in serving customers (as passengers). However, this role has been neglected by others actors. In this respect, the role of other actors (especially arranged by the government) should have been to protect and pay attention to protecting and ensuring the rights of drivers. The responsibilities of the cooperatives or route-unit supervisor should not be limited to maintaining the routes, but also to improve the representation of the paratransit drivers and the owners.

Local government has developed the strategy and instruments to improve paratransit services. However, because the integration of the public transport has to link to the upper-level scale (Greater Bandung), coherent coordination is needed to achieve development goals. This requires an extended role and responsibility of provincial government to facilitate and coordinate with the lower level in Bandung Basin.

\subsection{Contextual Interaction Theory Analysis of Paratransit}

Chapter 3 described the dynamic interaction between the target actors (represented by the paratransit owners) and the implementing actors (government or cooperatives). However, here in Chapter 5, are some target actors we need to recognise and to analyse their motivation, cognition, capacity and power. These include those from the cooperatives, drivers, route unit supervisor, and passengers.

In Chapter 3, the pivotal point role, from the local government perspective (as the implementer), hinges on the positive leadership from the Mayor. This was proven by the implementation of the School Bus (2016) and a change of leadership in the Transportation Department. Other 
infrastructure developed includes: public transport information on every route, bicycle parking lots, and paratransit vehicle being replaced by a higher engine specification in 2017 .

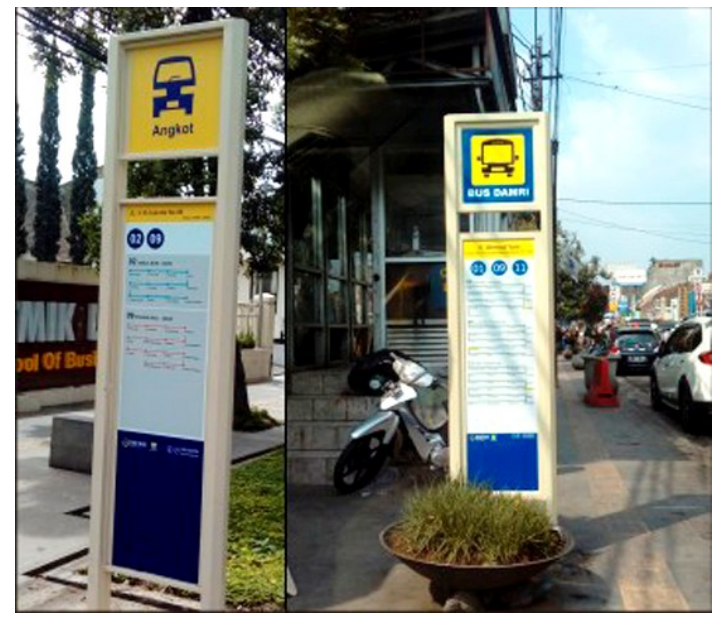

Figure 5.1: Information of public transport in certain areas in Bandung City. 27-12-2017

By the end of 2017, the cognitive aspect of MRV (measurement, reporting, and verification) process under the Local Action Plan for GHG emissions used the format of monitoring, evaluation, and reporting (PEP) used by the Planning Agency. The differences between MRV and PEP are that there is no validation or verification in the PEP report. The PEP informs the mitigation activities, as specified in the budget form, but not the actual percentage of GHG emissions reduction. The validation or verification of the GHG emissions does not reflect the factual situation. Consequently, this reduces the transfer of information on measuring the improvement and GHG emission. From the resource aspect, the Local Transport Department still lacks resources to improve infrastructure or to reduce private vehicle usage.

\subsubsection{Motivation}

The target actors, such as passengers and paratransit users, who are switching to other vehicle modes, feel the lack of motivation in using paratransit. The passengers who use paratransit were those people who had little or no choice to use other transport modes, or a need to carry the goods. The poor performance of urban transport becomes the significant factor for these users. Interviews with Local Transport Department also confirmed that paratransit users are people who do not have any choice for transportation or those who don't have vehicles 52 . "Current paratransit is in the worse condition because it is hard to compete with other modes of transportation, particularly motorcycles. The use of motorcycles has become common in

52 Based on the surveys with users and interview to the Transport Department and cooperatives (September - November 2016) 
Bandung City and this is related to the condition of the roads that are often jammed which allows motorcycle users to pass by" said the Secretary of Local Transport Department.

The image of urban transport is one where they often halt to lift passengers ('ngetem') and make the trip take longer time than needs be (see Fig. 5.2). The government and the passengers complain of such conditions. Therefore, it is not practical for people who have various destinations to use paratransit transport. The issue of paratransit is that management is not optimal and they operate with low performance. However, this condition also pertains to other public transports as well, such as taxis and buses.
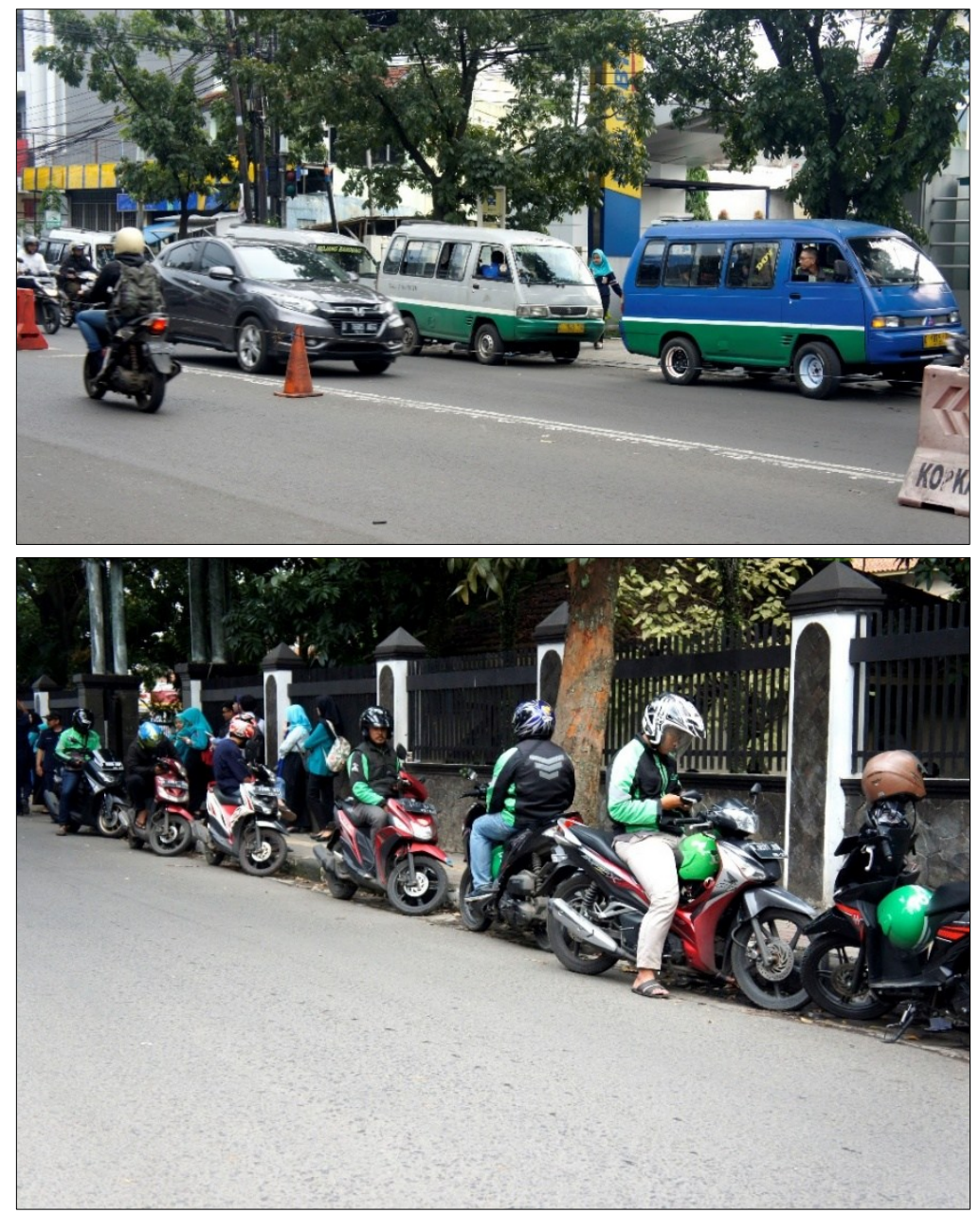

Figure 5.2: Paratransit drivers waiting for passengers to get into vehicles (pic. above) while the online motorcycle taxies wait for the nearest passengers (pic. below). 20-02-2019 
Transport customers now prefer to use online taxis (application-based transport), instead of conventional taxis, because of their cheaper fare ${ }^{53}$. Before 2016, "the application-based taxis" were illegal because they neither had car permits nor a legal entity for the business. This condition also applied equally to online motorcycle taxis "GO-JEK". However, this applicationbased taxi continues to evolve into the transportation backbone in Jakarta and Bogor. The local transportation department has the power to reject Uber, GO-JEK or Grab cars as forms of public transport. The drivers of paratransit and taxi several times performed mass strikes to influence the government to stop the online taxis. In 2018, the government asked the application ridesharing companies to form a transport service company. This was also stipulated in the Ministry of Transportation regulation number 108/2017 regarding organising public transportation using public vehicles. It is stated that online taxis which do not commute on only certain routes are now considered as special lease transport or "angkutan sewa khusus".

The Transport Department realised the potency of paratransits had yet to be explored. The number of paratransit vehicles in Bandung has exceeded the limit. The secretary of the Transport Department said: "We try to buy the paratransit and replace it with the TMB bus. However, we are constrained by the permits since the Audit Board does not allow us to purchase used cars such as angkot". Paratransit management is also difficult as they do not belong to Bandung City, but also come from the Greater Bandung Metropolitan areas, such as Cimahi, Soreang, and Cileunyi. The permit, supervision or monitoring of paratransits are conducted by other regions. The difference between them is the validity period, as other regions do not limit the permit to ten years and only have to pay for route extension permits every five years.

Local Transport Department technical coordination meetings with governments, other regions (Central Java and East Java) have severe impact because of the load factor. This has significantly dropped to below 50 percent. To date, most urban cities in Central Java do not use paratransit minibuses as public transport. Nevertheless, the load factor in Bandung City is still better.

Several factors causing people to be reluctant in using paratransits. First, people need time reliability. Second, paratransit services do not comply with regulations, such as meeting the minimum standards of comfort, safety, orderly, promptness, discipline, and affordability. The local rules about this are local regulation number 03/2005 about discipline, cleanliness and aesthetic. The citizens forfeit if these rules are not complied with.

The Transport Department has innovations to improve the use of paratransit, such as (1) rerouting and re-pooling; (2) "jumat ngangkot" or paratransit on Friday; and (3) mobile application for paratransit. The cooperatives have supported all these programmes. However, so far, these have not run well. Other approaches, such as gas conversion and advertising paratransit vehicles also have similar poor results. Consequently, the cooperatives felt the government was not serious in helping urban transport. Instead, some programmes have reduced the income of

\footnotetext{
53 In 2018, Grab has acquired Uber's Southeast Asia operations (Cambodia, Indonesia, Malaysia, Myanmar, the Philippines, Singapore, Thailand, and Vietnam) (Brophy, 2018).
} 
paratransits, such as the implementation of school buses and TMB. Therefore, many paratransit vehicles remain parked and unused, particularly between 09.00 and 11.00 in the mornings.

Drivers feel little motivation to meet minimum service standards. There is no fixed daily revenue for drivers. They only surrendered and accepted the situation. Nowadays, it is tough to run urban transport. It has many rivals, especially from buses and motorcycles. Every week, drivers have to cover their deposit to paratransit owners (setoran), particularly for the drivers on route 23 on weekend time on Saturdays, when most students and workers are on holiday. Even drivers operate on higher load routes, e.g the Ciroyom - Cikudapateuh track, find it difficult to meet their owner deposits. "In the past, owner asked for 14 euro per day, nowadays the owner lowering the deposit to become 10 euro. In the past, just driving for only one "rit" (round-trip), I could earn enough money for deposit (setoran) and the rest went to my family. I can operate for $5-6$ roundtrips under normal conditions, if congestion occurred, I could only drive for 4 round-trips. Now, it is hard to collect money, even just to pay the rent to the owners".

Many paratransit drivers in lower load factor areas resigned because of this situation. For example, the driver of route number 08 (Leuwipanjang -Antapani), felt that his route was the worst. In the past, the route number was 05 between Cicaheum - Cibaduyut. Due to some problems (recklessness of the drivers), these paratransit vehicles changed their colour from red to green to reduce their image and bad habits in an effort to reduce protests that had escalated from the community. The Mayor of Bandung in November 2015 inaugurated new paratransits with a different route so they would never protest or complain to the government, even though buses, such as the TMB, Trans Bandung Raya, and School Bus pass through the same path and, thereby, drastically reduce their income.

In summary, all actors are motivated to manage and maintain public transport sustainability, particularly the paratransit modes. The mitigation actions for lowering GHG emissions are not particularly acknowledged by all actors, even though some programmes have tried to reduce GHG emissions by rerouting and re-pooling, traffic engineering, vehicle emission testing and gasfuel programmes. The external pressure, such as the ride-sharing applications Grab and GO-JEK, has demotivated paratransit owners and drivers to maintain better services.

\subsubsection{Cognitions}

The cooperatives argued that the use of mobile phone reduces their travel demand. The ubiquity of information tools, such as cellular phone, makes information exchange easier. To date, people will call first before setting off on a journey. It is easier to exchange information via phone than by meeting directly, and it reduces costs. Researchers have found out that telecommuting or teleworking that use information and communication technology (ICT) can reduce passenger vehicles-miles travelled (VMT) (Farag, Dijst, \& Lanzendorf, 2003; Hiselius, Rosqvist, \& Adell, 2015; Sangho Choo, Mokhtarian, \& Salomon Leon, 2002) 
All actors acknowledged that the use of motorcycled reduces the use of paratransit. The number of motorcycles has increased sharply because of their low and affordable price. Generally speaking, each household has a motorcycle. The Transportation Department and the cooperatives were aware that the re-routing programme would meet some obstacles and be vulnerable to conflict. The Transport Department said that the main aim of the re-routing programme was to increase the feeders, to reduce blank spot areas, and attempt to disperse routes to increase services. The current blank spots are still served by 'ojeks' or 'becaks'. The Transport department and the cooperatives have tried to implement the programme on probation on three routes. However, the trial indicated only one spot felt safe or did not conflict with other paratransits or public transport. The Transport Department found that even changing the route only 100 meters would trigger conflict. One route change generated fatalities (Cibaduyut - Cicaheum) that were managed by Kobutri. "It is hard to implement the programme in the field. I do not know how to help the paratransit because the problem is not as simple as it looks. The changes will be intertwined with each other" said the Head of the Transport section.

The Transport Department reported that an influx of TMB activity would occur when DAMRI (city bus transportation owned by the state-owned enterprise) stops operating while using the same route and services. DAMRI is a state-owned enterprise that, nowadays, operates well and has increased comfort levels. In Bandung City, they deployed the Trans Bandung Raya programme where all urban buses share the same road with paratransits.

The Transport Department acknowledges the downside of TMB as the buses use the same road in conjunction with other public transports. This differs from other regions, such as Jakarta or Central Java, because there is no particular separator between lanes for bus or regular vehicles. The Transport Department stated that the bus lane occupies the national road, so it is forbidden to use the space in the middle of the road. Another reason is the lack of available and to use as bus lanes as has been discussed at national level. Furthermore, the TMB schedule is not fixed yet, but this service is better than paratransits in terms of safety, comfort, and time management.

The cooperative organisations, such as Kobanter Baru, Kobutri, and Kopamas, only manage the organisation alongside collecting mandatory dues and principal fees. The function is to accommodate members and help the regulation requiring paratransits to incorporate as legal entities. If conflict arises, a cooperative representative will attend and, in some cases, the owners of paratransit will be present.

The cooperatives route-unit supervisor (KPU) has a critical role acting a facilitator to the drivers and other stakeholders. The drivers admitted the roles of KPU are diverse. They can help drivers in trouble with officer and passengers, or when protested by other public transports. The KPU also provide help to the drivers in case they have to pay a fine, need more money, or collect their contribution in case of illness. The information received by the drivers usually comes from the 
KPU. The KPU's role is as a linking actor ${ }^{54}$ bridging information to the drivers, the cooperatives or the owners.

The cooperative is not merely the representative of paratransit owners because sometimes they have different purposes. When conflict occurred with the launch of TMB and School Bus programmes, the cooperative wanted them abolished and suggested local government provide a subsidy for paratransits in the form of a coupon. Furthermore, in terms of bus conversion, the Kopamas cooperative were ready to switch their paratransit vehicles to a larger model.

The central government assisted local government in technically-related policies. There were no subsidies for the vehicles spare parts. The central government has been planning to procure a card system and reduce spare part fees, but this plan had not been implemented. The local transport department felt that the central government did not adequately facilitate the programme. Support from central government did give a vehicle tax reduction of $30 \%$. The cooperative (Kobutri) argued that paratransits did not meet minimum service standard because of the lack of subsidies for the owners.

The cooperatives recognised that some programmes were trying to improve urban transport services, including the (1) re-routing and re-pooling; (2) "jumat ngangkot" or encouragement to use urban transport on Friday; and, also, (3) mobile application for urban transport. However, not all of the programmes were properly informed or relevant information disseminated. The cooperatives interpreted the programmes as having the objective to raise the income for paratransit. The reality is that they felt government were not implemented all programmes actively. The cooperatives were aware that the local government was focusing on the TMB and School Buses.

However, the poor performance of paratransit was recognised by the cooperatives and admitted by the drivers. The Kobutri takes responsibility for minimum service standard for paratransits to cover off comfort, safety and orderliness. Comfort means paratransits should not allow smoker, beggars, and street singers' in their vehicles. Safety means vehicles should be in good performance and on time safely. Orderliness means drivers and paratransits are in the orderly condition. However, paratransit drivers always stop ('ngetem') to seek out passengers and were always blamed as the source of congestion; an opinion disputed by the cooperatives. "The people should know that from the data, at every weekend around 25.000 vehicles are entering Bandung City. This information has to be delivered to the community", Head of Kobutri said.

Kobanter Baru knows the aim of buses operational in Bandung City is to unravel the congestion, and that is the duty of government to provide transportation. The Kobanter Baru emphasised the provision of urban transport had been independent, without assistance from the government.

54 Linking actor has the role to bridging the information from the implementers to the target actors (Mohlakoana, 2014) 
They further stated the government needed to provide a breakthrough for urban transport by equipping the rules to make the commercial banks give soft loans.

From the owner's point of view, they interpret the affordability aspect not only for passengers and society, but also for their commercial viability. Paratransit entrepreneurs need affordable spare-parts and a profit margin. Government should facilitate these balances, not the cooperative. To illustrate, car tyres have to be affordable for the paratransit owners. Government could provide a subsidy to paratransits and has the authority to do so, possibly by using the stateowned enterprise that provide public transport services. Conventional banks also must trust paratransit owners. "If the fisherman and farmers have received financial assistance, why are the paratransit owners not allowed to take this opportunity?" said the Head of Kobutri manager.

All in all, the actor's information to lowering GHG emissions has been shared with the cooperatives. The absence of updating information about the programmes creates conflict between other actors and drivers. The incoming information generally comes in one way through dissemination from the government. The information is forwarded by the cooperatives to the route-unit supervisors, representatives of paratransit owners and drivers.

\subsubsection{Capacity and Power}

The power to restrict paratransits by the Local Transport Department is based on their requirement to fulfil safety, comfort, and environmental aspects (emission test). Many paratransits do not meet emission test minimum standards. Emission tests are part of the feasibility test held every month or sometimes even 10 times a year as paratransits are chosen at random. The message associated with the test was to disseminate and encourage awareness amongst paratransit owners to maintain their vehicles. The typical paratransit owner pushes their drivers to use the vehicle to the maximum possible. The feasibility and emission test are sometimes neglected.

The government experience of the Kobutri cooperative organisation in managing paratransit exists in several cities in West Java dealing with public bus transport. In Bandung, the Kobutri only manages one-fifth from the overall paratransit trajectory. However, they have wider experience to attract local government to make this cooperative a counterpart.

The local government and cooperatives believed that, in West Java, paratransits are still dominant as public transport and the availability of this resource can serve the community, particularly in Bandung City. The condition was different from those of the East Java and Central Java as mass transportation use is bigger than paratransit activity. The geographical condition of Bandung City roads makes the paratransit more suitable than the bus. Kobutri data indicates paratransit number about 5,583 units on 38 routes. The Kobutri acknowledged paratransits in Bandung had their golden age in 2003 and now it was at the beginning of the rejuvenation of the vehicle. The implementation of the validity period of paratransit was very appropriate in terms of safety. 
The capacity of Kobutri was seen in terms of the trustworthiness by the government when working on several paratransit programmes. Kobutri was involved in (1) the blue-sky programme that encourages the use of fuel gas; (2) encouragement to use public transport on Fridays; and (3) paratransit exclusive or 'Ngangkot Ekslusif'. This blue-sky programme was a pioneer of the vehicle emission test programme, which is still ongoing.

Besides Kobutri, Kobanter Baru has more than 4.600 members. Established in 1976, Kobanter Baru has become a pioneer in dealing with paratransit. To date, around 90 percent of the routes that existed in Bandung derived from the Kobanter proposal. Kobanter Baru pioneered removing the motorised tricycle or 'bemo' in 1988. The reason to abolish the "bemo" was air and noise pollution.

The Kobanter Baru felt they did not have the power to change the income scenarios of urban transport. The increased use of motorcycles and public transport buses has decreased the income of paratransit. "We are not allergic to the existing regulations. However, in this case, it should be properly balanced", said one of the managers of Kobanter Baru. The TMB is using the existing routes of urban transport, and School Bus is free of charge. The paratransit, as a small-medium business, felt they are already facing unfair competition.
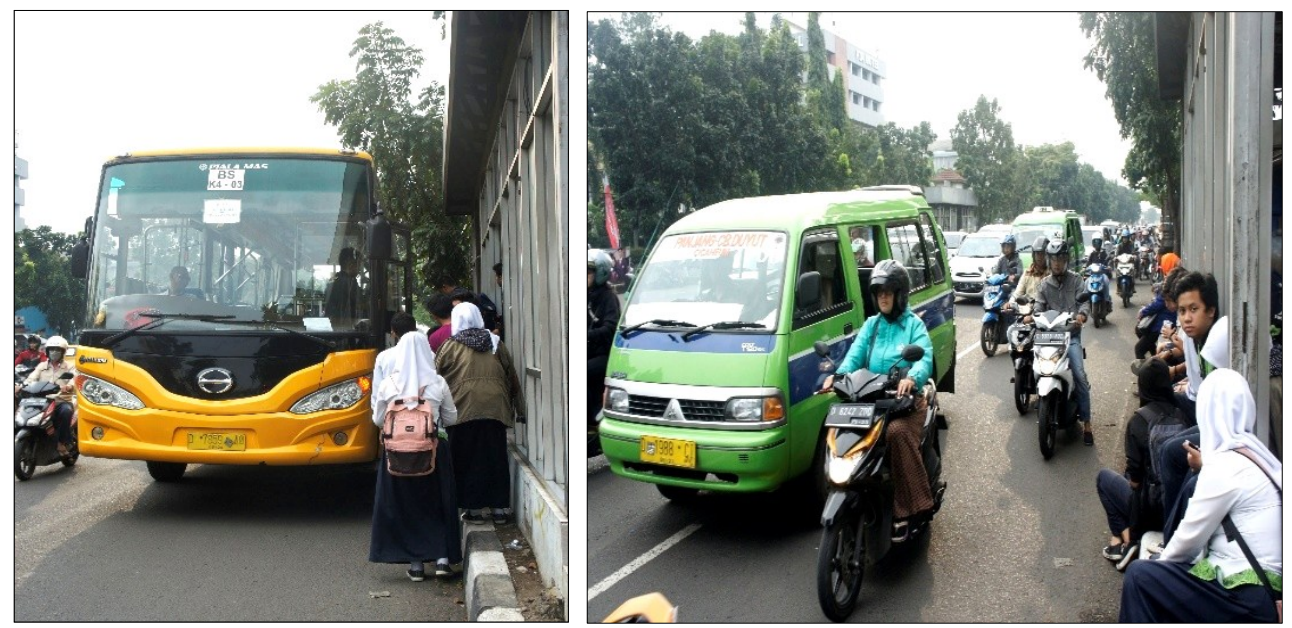

Figure 5.3: In the same lane, a school bus is free of charge and attracts student to ride (left side), while a paratransit struggles to get a passenger (right side). 20-02-2019

Kobanter Baru has already suggested that local government should arrange a reduction or conversion of existing paratransit vehicles. The conversion programme would purchase five paratransit vehicles and convert them into one TMB. The paratransit purchased by government should be recycled so it will not be return back again to the street. 
For effective and profitable urban transport business, the Kobanter Baru admitted their decline in revenue. However, they still survive. The golden era of paratransit was from 1998-2004. Kobanter Baru mentioned the ASEAN Free Trade Area (AFTA) enacted in 2005 resulted in increased numbers of private vehicles. Furthermore, many private vehicles were illegal as public transportation in Bandung City (Kurniawan, 2016; Syaifudin, 2016).

Kobanter Baru and the local Transport Department acknowledged unauthorised urban transport serves almost 30 percent of transport demand in Bandung City. This condition is exacerbated by paratransit from outside regions entering Bandung. Kobanter urged local government to solve these problems, particularly managing urban transport from outside Bandung, such as Cimahi, West Bandung Regency, and Bandung Regency. However, there is no clarity regarding limits on such transport. The Transport Department is aware of illegal private cars and urban transport in exceedance of the 10-year vehicle eligibility and that this created unfairness for local transport entrepreneurs. They needed cooperation with other stakeholders to reduce the use of illegal transportation in Bandung. Even though the government conducted some activities, such as frequents raid, illegal paratransits still run.

Kobanter Baru suggested the TMB to recruit drivers from their members. In the past, TMB had to join a consortium with the cooperatives, besides government. However, the TMB existing management is not a consortium and this will remain a problem because of the existing urban transport routes. The drivers are the weak actors in terms of resources, since the obligation to perform their task has three consequences: (1) to provide the better services for the public; (2) to earn the income; and (3) to fulfil the daily fee instalment for the paratransit owner.

To sum up, the cooperatives have experience in organising public transportation, not only for paratransit, but also for public bus transportation. The capacity to cooperate with other stakeholders, such as financial institutions, has been built over several years. The cooperatives have the capacity and power to collect fees from drivers. However, the cooperatives do not have the capacity to organise and manage the drivers. The power is in the hands of the owners to select drivers and decide on the daily instalment to collect. Local government has the power to regulate the vehicles based on their requirement. The drivers become the weak party for both their capacity and their power. 


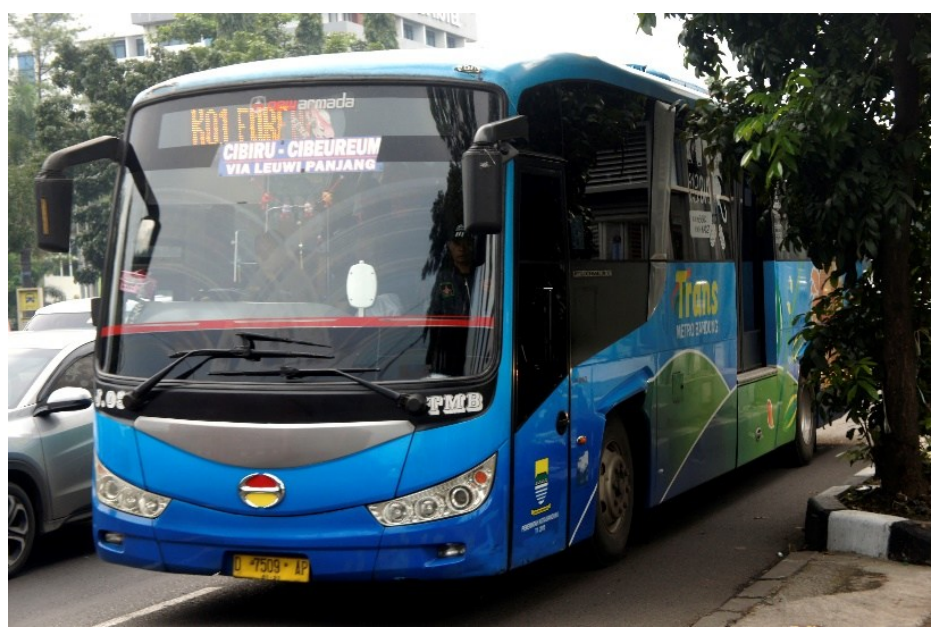

Figure 5.4: The Trans Metro Bandung (TMB) shares the same lanes with paratransit and school bus at Jl. Soekarno-Hatta, Bandung (Cibiru-Cibeureum corridor). 20-02-2019

\subsection{Discussion and Conclusions}

The multi-level and differing scales of paratransit governance indicate the local level is dominant in policy discussions. The provincial level accepted paratransits as a small-medium enterprise (SME) programme that existed. However, in terms of spatial scales (ecological landscapes), the policies regarding vehicle age restriction were not applicable or even similar in every region in the Bandung Basin. To realise the co-benefit of reducing air pollution and lowering GHG emissions in one ecological scale, the management of paratransits has to have a level playing field and apply the same rules.

The relevant actors are involved in managing local paratransit development. However, as a SME, the role of paratransit owners was only viewed as a target for investment by the cooperatives or enterprises. The government appeared to override paratransit services and considered the future programme would be more focused on the local government (TMB and School Bus) programmes and national strategy. The governance literature ('governing without government' as declared by Rhodes (1996)) saw the contribution of paratransit as an important non-state actors already well experienced over more than a decade. The paratransit drivers offered a source of job opportunities for unskilled or low-income persons. Li et al. (2011, p. 1145) reported "in considerably long period of time with the current economic developments in developing countries, regulating and incorporating paratransit into formal public transportation system rather than simply banning it, is a wise method to realise the sustainable urban transportation".

The problems of implementation for paratransits have been attempted only in the short term. Problems in the future will persist, especially with regard to how to manage the paratransit owners and drivers and how to manage networks that operate in a similar niche (Paratransit, TMB, DAMRI, Trans Bandung Raya, and ride-sharing transportation, such as GO-JEK or Grab). 
Various public transportation actor goals lead to competition and conflicts. Even though all means of transportation have the same, each public transport mode has different ideas, values and approaches. The renting out system in paratransit management has generally neglected services to passengers. Local level actors (government as a facilitator) need to reduce the growing conflicts among the public transport service providers. However, the existing problems need higher-level actors in the central and provincial level to be involved and responsible.

Strategies and instruments for paratransits to comply with standard requirements have been created at the local level. They acknowledge the need to reduce GHG emissions by encouraging the use of public transport and tightening private vehicle ownership. However, those deployed have proved difficult to implement and several programmes have not been sustained. The strategies have to provide synergies between the incentive systems and include policy instruments into programmes that will also require strong collaboration and enforcement.

Public transportation has existed for more than two decades. The experiences of all actors in dealing with paratransit recognise their responsibilities. However, it appears that no clearly assigned responsibilities exist for each actor.

\subsection{Improving public transport as part of climate co-benefits}

Besides paratransit governance, we evaluated their co-benefits. It is widely known that the paratransit sector has lower performance levels and is a source of negative aspects, such as congestion, air pollution, noise, and traffic accidents. However, one study shows that paratransit compensated for inadequacies of many roads in southeast Asia cities (Cervero, 1991, p. 1). A Bandung City performance report showed paratransits services lacked quality and exhibited a low degree of entrepreneurship (Dinas Perhubungan, 2015). Despite these shortcomings, paratransits furnished advantages, such as mobility for transit passengers, job availability for lowskilled workers, cheap labour force, and flexibility to serve areas outside the main network (Cervero \& Golub, 2007; Li, Nugroho, Fujiwara, Zhang, \& Linh, 2011).

The regional action plan of climate change mitigation in the transport sector has only one activity connected with reducing GHG emission, viz. to escalate the use of biofuel by $15 \%$ by 2025 (BPLHD, 2015). There are five programmes to support the activities, i.e. (1) education and training of vehicle emission test; (2) management and traffic engineering in Bodebek, Metropolitan Bandung and Metropolitan Cirebon; (3) management and traffic engineering at level crossings; (4) development of railway transport; and, (5) management and traffic engineering at provincial road. The local government has to inform those programmes with activities, such as the evaluation of measurement, reporting, and verification (MRV) of emission measurement from operational intelligent transport systems, TMB or Bus Rapid Transit.

From all of these, only one programme has direct contact with paratransits - the vehicle emission test. This test is already implemented annually with the cooperation between West Java EMA and Bandung Transportation Department. This paratransit management aspect could create 
synergy if linked to the construction of pedestrian sidewalks where passengers would adapt their walk patterns, if there was a frequent use of public transport. "However, there is still some ambiguity in terms of a parking lot. If the city encourages the use of non-motorised transport or the use of public transport, there is no need to build the parking lot beside the pedestrian area" said the Head of Section of West Java EMA.

There is a programme of low carbon transport, namely gas fuel conversion. This programme has existed since the 1990s. So far, the paratransit has failed to meet any of these objectives. At present, 50 pieces of converter kit have been installed and distributed to the Antapani route since 2016, assisted by the National Gas Company (PGN). If the paratransit owners were interested to install the converter kit, they had to spend US\$ $850^{55}$ per piece. However, this amount was too much of a burden for many owners. The gas converter programme remained a pilot project for a long time but has now been postponed.

Paratransit replacement is conducted every 10 years and has the potential to reduce GHG emissions. To date, technical aspects, such as vehicle fuel efficiency, have not been part of vehicle requirement, despite the fact that central government policy seeks to develop the Low-Cost Green Car (LCGC) as the low-carbon vehicle (car engine with 1,200cc and average fuel efficiency $20 \mathrm{~km} / \mathrm{l})$. Many vehicles failed to pass those standards. For example, many vehicles with a range of 1,300-1,500cc have a fuel efficiency range of only 10-13km/l (Brogan, 2012; Zal, 2012). The $\mathrm{CO}_{2}$ emissions from a minibus, such as Daihatsu Gran Max and Suzuki APV, were averaging 180 $190 \mathrm{~g} / \mathrm{km}$.

The evaluation of co-benefits is described in Chapter 6.

551 USD equal to 13,518 IDR 


\section{Chapter 6: Evaluation of Co-Benefits Approach Criteria}

\subsection{Introduction}

Mitigation action plans and scenarios to lower GHGs emissions have been ratified in several developing countries. The actions include policy approaches in the form of Nationally Appropriate Mitigation Actions (NAMAs) (Olsen et al., 2015). The concept of NAMAs was agreed upon in 2007 at the UNFCCC COP 13 in Bali, when Indonesia encouraged developing countries to implement the climate mitigation goals that NAMAs emphasise. Previous concepts to attain low carbon goals in the form of Low Carbon Development Strategies (LCDS), later became referred to as Low Emission Development Strategies (LEDS) (Mdivani \& Hoppe, 2016; Olsen et al., 2015; Tyler, Boyd, Coetzee, Torres Gunfaus, \& Winkler, 2013).

The incorporation of NAMAs and LEDS instruments has been described as a necessary approach to achieve sustainable development (Mdivani \& Hoppe, 2016). So, a strategic choice to enact mitigation actions would also implement Sustainable Development (SD) action plans and policies to attain those goals (Friman \& Linnér, 2015).

The climate co-benefits approach can be attractive politically to developed countries (Bollen et al., 2009; IGES, 2011). Strategic actions in NAMAs prioritise clean development action, so that both GHG reductions and SD objectives can be attained.

\subsection{Low-Carbon Transport Governance as part of LEDS}

Transport sector policy plays a vital role in Indonesia. The policy goal is improve management and regulation of transport activities to create a better arrangement of transport resources. This involves public sector and private sector effort. Local level government is involved as a planner or manager of several transport system components. Their role is to manage the public services transport system and this is embodied in the regulatory framework.

Activities in the transport sector include rail-based public transport, road-based public transport, road freight transport, and private transport (Kamaluddin, 2000). These activities have different characteristics. Their influence on regional development depends on the structure of the economy, the distribution of population, and income distribution. Road transport policy for public services can improve active transport (and support non-motorised modes). This connects to measures that can reduce $\mathrm{CO}_{2}$ by decreasing the use of fossil fuel or $\mathrm{CO}_{2}$ sinks. Transport sector policy also covers aspects of environmental policy, such as helping to manage air pollution control with active transport (environmental benefits of promoting alternative transport) (Xia, Zhang, \& Crabb, 2013).

The future demands to deal with issues in the transport sector will require most attention if the direction of technology developments and their current efficiency levels remain at their current business as usual (BAU) levels. Technical reports from the National Council on Climate Change (2009) and studies conducted by Kahn Ribeiro, et al. (2007), suggest transport emissions in 
Indonesia could double within ten years and have increased nearly threefold from 2000 to 2013 (Utomo, 2015). The Gol has adopted a sustainable transportation and assessment framework under Indonesia's Sustainable Urban Transport Initiative (SUTI) (Jaeger, Nugraha, Zusman, Nakano, \& Daggy, 2015) to manage this escalation. This SUTI has been developed alongside the implementation of NAMAs. However, apart from implementation at a provincial level, most government efforts remain as a work in progress.

The concept of Sustainable Transportation (ST) has evolved from Europe, America and Australia (GIZ, 2004; Goldman \& Gorham, 2006; Gudmundsson, 2001; Schiller et al., 2010; TRB, 2001). Table 6.1 shows the distinction between BAU and ST with their different perspectives.

Implementing ST in Bandung City has become a priority (Sutandi \& Pinem, 2017) as transport here faces excess demand and lack of supply of road capacity. Whereas total vehicle growth in Bandung City was $9.3 \%$ in 2013, road length growth was only 1.3\% (Bappeda, 2011, 2013). These figures compare to economic growth that was $7.8 \%$ in 2016 that itself was higher than the national average (5.0\%). This situation tends to increase the vehicle ownership in Bandung when this trend is not compensated for with transport infrastructure.

Table 6.1: Comparison of Business as Usual and Sustainable Transportation.

Source: Schiller et al., (2010)

\begin{tabular}{|c|c|}
\hline Business as Usual Transportation (BAU) & Sustainable Transportation (ST) \\
\hline Emphasises mobility and quantity (more, faster) & Emphasises accessibility and quality (closer, better) \\
\hline Emphasises one mode (uni-modality, automobility) & Emphasises plurality (multi-modality) \\
\hline Often lacks good connections between modes & Emphasises interconnections (intermodality) \\
\hline Accommodates and accepts trends & Seeks to interrupt and reverse harmful trends \\
\hline $\begin{array}{l}\text { Plans and builds based on forecasts of likely } \\
\text { demand (predict and provide) }\end{array}$ & $\begin{array}{l}\text { Works backwards from a preferred vision to } \\
\text { planning and provision (deliberate and decide) }\end{array}$ \\
\hline Expands roads to respond to travel demand & Manages transportation or mobility demand \\
\hline Ignores many social and environmental costs & $\begin{array}{l}\text { Incorporates full costs within planning and } \\
\text { provision (internalisation of externalities) }\end{array}$ \\
\hline $\begin{array}{l}\text { Transportation planning often in 'silos' } \\
\text { disconnected from environmental, social and other } \\
\text { planning sectors }\end{array}$ & $\begin{array}{l}\text { Emphasises integrated planning combining } \\
\text { transportation with other relevant areas }\end{array}$ \\
\hline
\end{tabular}


The BAU patterns listed in Table 6.1 are likely to worsen under the continuous and the growing trend of motorisation. This would increase the wider costs to society, particularly environmental problems of air pollution, noise, accidents, poor health, and social impacts. Studies and methods have been conducted to address internalisation of externalised costs of the transport sector (Liu \& Bohlin, 2013; Mailbach et al., 2008). Sectors with substantial emission rates can be analysed and subjected to mitigation efforts. Studies on urban areas show an increase in environmental policies dealing with the economic sectors, health, water and energy use, transport, and air pollution (Lee \& Van De Meene, 2013).

The Ministry of Environmental Energy in North America (US and Canada) developed three indicator domains relating to sustainable urban transport. These dis-aggregate into eighteen elements as shown in Table 6.2 (Gudmundsson, 2001).

Table 6.2: Sustainable urban transport in three domains. Source: adopted from Gudmundsson (2001)

\begin{tabular}{|c|c|c|c|c|}
\hline \multicolumn{2}{|r|}{ Environmental domain } & \multicolumn{2}{|r|}{ Societal domain } & \multirow{2}{*}{$\begin{array}{l}\text { Economic domain } \\
\text { 15. Affordability }\end{array}$} \\
\hline 1. & Limiting emissions & 8. & $\begin{array}{l}\text { Meeting access needs of } \\
\text { individuals }\end{array}$ & \\
\hline 2. & Limiting waste & 9. & $\begin{array}{l}\text { Meeting access needs of } \\
\text { society }\end{array}$ & 16. Efficient operation \\
\hline 3. & $\begin{array}{l}\text { Minimising consumption of } \\
\text { non-renewable resources }\end{array}$ & 10. & $\begin{array}{l}\text { Access needs are met } \\
\text { consistent with ecosystem } \\
\text { health services }\end{array}$ & $\begin{array}{l}\text { 17. Choice of transport } \\
\text { mode }\end{array}$ \\
\hline 4. & $\begin{array}{l}\text { Limiting consumption of } \\
\text { renewable resources to the } \\
\text { sustainable yield level }\end{array}$ & 11. & $\begin{array}{l}\text { Access needs are met } \\
\text { consistently with human } \\
\text { health }\end{array}$ & $\begin{array}{l}\text { 18. Support for a vibrant } \\
\text { economy }\end{array}$ \\
\hline 5. & $\begin{array}{l}\text { Reusing and recycling } \\
\text { components }\end{array}$ & 12. & Access needs are met safely & \\
\hline 6. & Minimising land use & 13. & $\begin{array}{l}\text { Access needs are met with } \\
\text { equity within this generation }\end{array}$ & \\
\hline 7. & Minimising noise & 14. & $\begin{array}{l}\text { Access needs are met with } \\
\text { equity across generations }\end{array}$ & \\
\hline
\end{tabular}

The selection of co-benefits can derive from any of these domains. The literature on co-benefits highlights certain indicators and aspects that pertain to climate change programmes, as the next section will elaborate.

\subsection{Selected Criteria Indicators of Co-Benefits}

There are two immediate types of co-benefits of interest: the environmental co-benefits of climate change policies and the climate co-benefits of environmental policies (Lee \& Van De Meene, 2013; Puppim De Oliveira, 2013). The first type aims to target how to reduce climate 
change as its first objective (e.g., inventory emissions and measurement). The second type aims to contribute to tackling local problems as the first objective (e.g., air pollution, water pollution). Present research of climate policy investigates other perspectives of climate change policy when using an integrated approach (Bollen, Johannes. C; Brink, C.J.; Eerens, H.C.; Manders, 2009).

This chapter will deal with climate co-benefits that deal with local environmental problems. The policy instruments that encourage lowering of GHG emissions have been described previously in Chapter 3 (see Table 3.4).

In general, the co-benefits approach is used to assess the impact of climate change mitigation (global) vis-à-vis other local environmental issues (Jack \& Kinney, 2010; Yedla \& Park, 2009). However, this approach conceptually can integrate climate change adaptation or mitigation actions to create synergies with environmental improvement (Dubash et al., 2013; van Vuuren et al., 2006). The so-called 'co-benefit approach' refers to the development and implementation of policies and strategies that simultaneously contribute to global change, whilst also tackling local environmental problems. This can contribute also to impacts on other developments, such as cobenefits in transport sector activities (Puppim De Oliveira et al., 2013). Thus, activities to reduce the air pollution, make fossil fuel use more efficient, and alleviate congestion have been integrated with the strategy to reduce GHG emissions.

The illustration in Figure 6.1 presents two phases for a generalised city. It maps wealth against the intensity of problems that range from the local to city to global scale. The co-benefit approach seeks to integrate local problem solving and show its impact on helping to impact on global problems. 


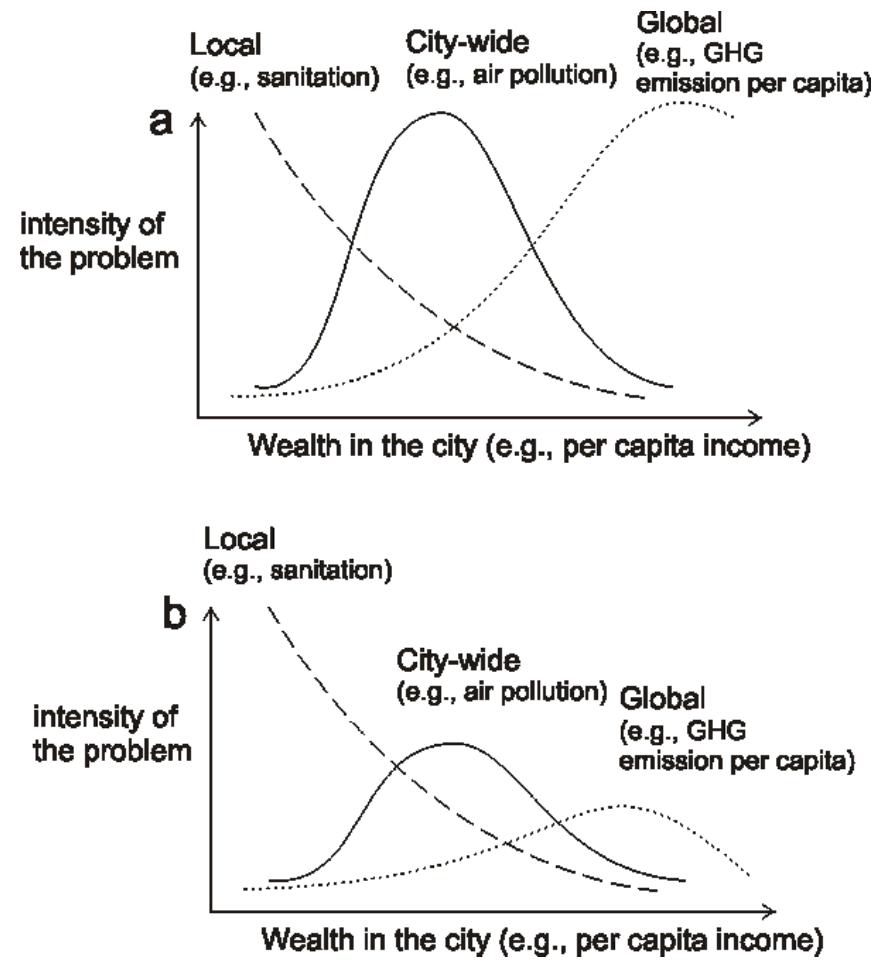

Figure 6.1: Aim of integrated local and global problem (a. typical wealth versus environmental burdens; $\boldsymbol{b}$. needed changes in the curves).

Source: McGranahan et al. (2001) in Puppim De Oliveira et al., (2013)

Figure 6.1a illustrates an existing state of affairs where economic growth and urbanisation have tremendously affected the environment. Even though some problems (e.g., local sanitation) can be addressed effectively, others, such as air pollution, still exist (e.g. transport sectors dependent on fossil fuels). If the Kuznets curve argument were to apply then, as community grow more environmentally conscious and prosperous, they further suppress environmental problems. However, this assumption has proved shaky at least and, until now, countries are still dealing with growing global GHG emissions. Governments dealing with protecting people from local environmental issues face both old and new obstacles to implement effective climate policies. Many cities face challenges coping with multiple levels in society and multiple levels of governance.

In Figure 6.1b, the intensity of the problems could decline if the wealth of the city increases. This shows the city reaping a co-benefits outcome to how it addressed the problems. This could be a solution for developing countries to deal simultaneously with the local and global problems. The success of cities to enhance their environmental quality could reduce the intensity of the problem. 
Co-benefits involving health benefits have been addressed in the literature (Jack \& Kinney, 2010; West et al., 2013). These public health policy approaches used air quality indicators of $\mathrm{PM}_{10}$, $\mathrm{PM}_{2.5}$, and $\mathrm{GHG}$ emission reduction in their co-benefits approach. The economic indicators of cobenefits divided into four aspects of: (1) reducing exposure to air pollution, (2) increasing physical activity, (3) improving nutrition (diet), and (4) reducing the risks that have to do with labour. Puppim de Oliviera et.al. (2013) illustrated the co-benefits approach with a framework to implement policies and strategies that simultaneously contribute to the global change, while also addressing local environmental issues and other developments (see Figure 6.2).

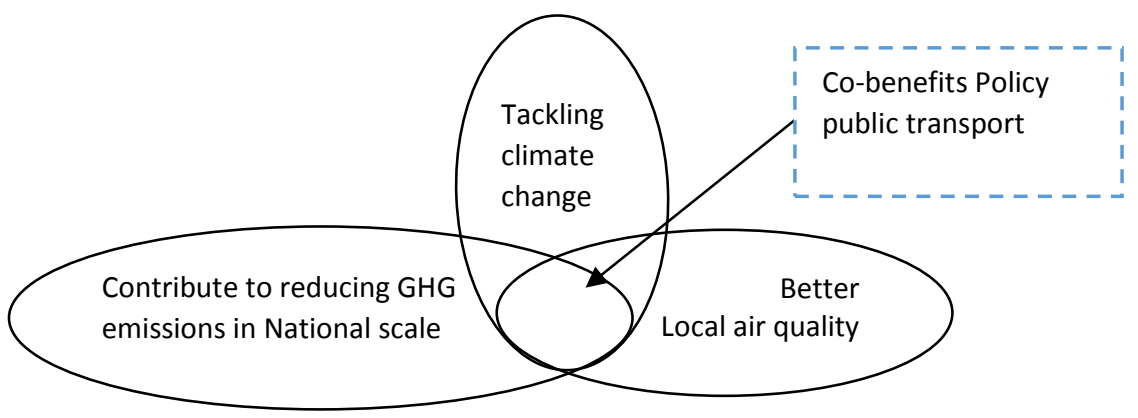

Figure 6.2: Framework of co-benefit approach in the transport sector. Source: adapted from Puppim de Oliviera et.al. (2013)

Several researchers have developed indicators to evaluate the co-benefits of policy instrument activities (see Table 6.3). These have also adopted measures to help policy makers in relation to sustainable development (Geels, 2011; Jaeger et al., 2015; OECD, 1997; Pavlovskaia, 2014). 


\section{Table 6.3: Indicator sources of co-benefits transport sector activities}

\begin{tabular}{|c|c|c|c|c|}
\hline Programme \& strategy & Outcome & Co-benefits & Evaluation indicator & Type of co-benefits \\
\hline $\begin{array}{l}\text { Methodological guidance on the } \\
\text { quantification of co-impacts and their } \\
\text { integration into climate-related } \\
\text { programmes (Ürge-Vorsatz, Herrero, } \\
\text { Dubash, \& Lecocq, 2014) }\end{array}$ & $\begin{array}{l}\text { Applicable } \\
\text { appraisals of co- } \\
\text { impacts for } \\
\text { decision making }\end{array}$ & $\begin{array}{l}\text { Energy-based } \\
\text { mitigation in } \\
\text { physical units and } \\
\text { monetary value }\end{array}$ & $\begin{array}{l}\text { Health impacts (outdoor and indoor air pollution, } \\
\text { energy poverty, noise, transport \& traffic, heat island); } \\
\text { access, affordability, and energy poverty; comfort \& } \\
\text { living conditions' PES; productivity; energy security }\end{array}$ & $\begin{array}{l}\text { Co-benefits for } \\
\text { climate change } \\
\text { mitigation }\end{array}$ \\
\hline $\begin{array}{l}\text { Indian climate change policy: exploring a } \\
\text { co-benefits based approach (Dubash et } \\
\text { al., 2013) }\end{array}$ & $\begin{array}{l}\text { Develop a } \\
\text { methodology for } \\
\text { operationalising } \\
\text { a co-benefit } \\
\text { approach }\end{array}$ & $\begin{array}{l}\text { Full range of } \\
\text { outcomes across } \\
\text { economic, social, } \\
\text { and } \\
\text { environmental } \\
\text { goals }\end{array}$ & $\begin{array}{l}\text { Growth (efficiency of resource use, creation of jobs, } \\
\text { energy security); inclusion (improving outcomes for the } \\
\text { poorest, reducing disparities in distribution); local } \\
\text { environment (air, water, land); carbon mitigation }\end{array}$ & $\begin{array}{l}\text { Co-benefits of climate } \\
\text { change policy }\end{array}$ \\
\hline $\begin{array}{l}\text { Assessment of co-benefits of black } \\
\text { carbon emission reduction in Southeast } \\
\text { Asia (Permadi, Kim Oanh, \& Vautard, } \\
\text { 2017) }\end{array}$ & $\begin{array}{l}\text { Emission } \\
\text { reduction } \\
\text { measures in } \\
2030\end{array}$ & $\begin{array}{l}\text { Air quality and } \\
\text { Premature deaths }\end{array}$ & Black carbon \& $\mathrm{PM}_{2.5}$ & $\begin{array}{l}\text { Co-benefits of air } \\
\text { pollution }\end{array}$ \\
\hline $\begin{array}{l}\text { Manual for quantitative evaluation of } \\
\text { the co-benefits approach to climate } \\
\text { change project (Ministry of the } \\
\text { Environment Government of Japan, } \\
\text { 2009) }\end{array}$ & $\begin{array}{l}\text { Applicable } \\
\text { criteria for } \\
\text { evaluation } \\
\text { methodologies }\end{array}$ & $\begin{array}{l}\text { Examples of key } \\
\text { areas (energy in } \\
\text { industry, waste } \\
\text { water, solid waste } \\
\text { landfill, public } \\
\text { transport } \\
\text { systems) }\end{array}$ & $\begin{array}{l}\text { NOx, Fossil fuel consumption (Tier } 2 \& 3 \text { ), economic } \\
\text { indicators (Tier } 1 \text { ) }\end{array}$ & $\begin{array}{l}\text { Activities using co- } \\
\text { benefit approach to } \\
\text { climate change }\end{array}$ \\
\hline $\begin{array}{l}\text { Bus Reduction Project EDSA - Filipina } \\
\text { (Hamilton \& Akbar, 2010) }\end{array}$ & $\begin{array}{l}\text { GHG emission } \\
\text { reduction from } \\
\text { buses }\end{array}$ & $\begin{array}{l}\text { Reducing fuel } \\
\text { emission of } \mathrm{CO}_{2}\end{array}$ & Environmental indicator & $\begin{array}{l}\text { Co-benefit } \\
\text { environmental quality } \\
\text { from transport sector }\end{array}$ \\
\hline
\end{tabular}




\begin{tabular}{|c|c|c|c|c|}
\hline Programme \& strategy & Outcome & Co-benefits & Evaluation indicator & Type of co-benefits \\
\hline $\begin{array}{l}\text { Sustainable urban transport - India } \\
\text { (Hamilton \& Akbar, 2010) }\end{array}$ & $\begin{array}{l}\text { Promotion of } \\
\text { sustainable } \\
\text { urban transport }\end{array}$ & $\begin{array}{l}\text { GHG emission } \\
\text { reduction }\end{array}$ & $\begin{array}{l}\text { Emission reduction from air pollution which improve } \\
\text { health }\end{array}$ & $\begin{array}{l}\text { Co-benefit transport } \\
\text { sector of } \\
\text { environmental quality } \\
\& \text { health improvement }\end{array}$ \\
\hline $\begin{array}{l}\text { Improving bike activities and the use of } \\
\text { public transit in Canada (Bizikova, Neale, } \\
\text { \& Burton, 2008) }\end{array}$ & $\begin{array}{l}\text { Develop a } \\
\text { network for } \\
\text { using bikes, } \\
\text { increasing transit } \\
\text { service coverage } \\
\text { and frequency }\end{array}$ & $\begin{array}{l}\text { GHG emission } \\
\text { reduction }\end{array}$ & Health indicator monitoring & $\begin{array}{l}\text { Sustainable } \\
\text { development } \\
\text { adaptation and } \\
\text { mitigation (SAM) } \\
\text { Co-benefit health } \\
\text { improvement }\end{array}$ \\
\hline $\begin{array}{l}\text { Modelling co-benefit from alternative } \\
\text { transport scenario on land/road } \\
\text { transportation (public transport, active } \\
\text { transport, bicycling, cycling, and walking) } \\
\text { in China (Xia et al., 2013) }\end{array}$ & $\begin{array}{l}\text { Vehicle emission, } \\
\text { transport/traffic } \\
\text { emission }\end{array}$ & $\begin{array}{l}\text { Identify specific } \\
\text { studies that } \\
\text { conduct multiple } \\
\text { benefits } \\
\text { evaluation of } \\
\text { alternative } \\
\text { transport } \\
\text { scenarios. }\end{array}$ & $\begin{array}{l}\text { Air pollution, air quality, car trips }\left(\mathrm{PM}_{2,5} \text { and } \mathrm{CO}_{2}, \mathrm{CO} \text {, }\right. \\
\left.\mathrm{O}_{3}, \mathrm{PM}_{10}, \mathrm{NOx}, \mathrm{VOC}\right) \\
\text { Health impact assessment \& economic using the } \\
\text { disability-adjusted life year (DALY) Health Economic } \\
\text { Assessment Tool, Environmental Benefits Mapping and } \\
\text { Analysis Programme (BenMAP), CRA }\end{array}$ & $\begin{array}{l}\text { Environmental, } \\
\text { economic - health }\end{array}$ \\
\hline $\begin{array}{l}\text { Comparative studies of urban climate co- } \\
\text { benefits in Asian cities ( } 40 \text { cities) (Lee \& } \\
\text { Van De Meene, 2013) }\end{array}$ & $\begin{array}{l}\text { Resources use } \\
\text { (water } \\
\text { consumption, } \\
\text { energy, } \mathrm{NO}_{2} \text {, } \\
\text { waste } \\
\text { generation), } \\
\text { demography and } \\
\text { economic factors } \\
\text { (GDP, } \\
\text { manufacturing) }\end{array}$ & $\begin{array}{l}\text { Key theories } \\
\text { about climate co- } \\
\text { benefits from } \\
\text { environmental } \\
\text { policies and } \\
\text { environmental co- } \\
\text { benefits from } \\
\text { climate policies }\end{array}$ & $\begin{array}{l}\text { Institutional policy factor; land use transport; public } \\
\text { transport (green space per capita \& } \mathrm{CO}_{2} \text { emissions per } \\
\text { capita) }\end{array}$ & $\begin{array}{l}\text { Climate co-benefit } \\
\text { Study comparative for } \\
\text { indicator. } \\
\text { Among the control } \\
\text { variables, GDP per } \\
\text { capita is a strong }\end{array}$ \\
\hline
\end{tabular}




\begin{tabular}{|c|c|c|c|c|}
\hline Programme \& strategy & Outcome & Co-benefits & Evaluation indicator & Type of co-benefits \\
\hline $\begin{array}{l}\text { Co-benefit analysis of an air quality } \\
\text { management plan and greenhouse gas } \\
\text { reduction strategies in the Seoul } \\
\text { metropolitan area (Chae, 2010) }\end{array}$ & $\begin{array}{l}\text { Emissions of air } \\
\text { pollutants from } \\
\text { various sources }\end{array}$ & $\begin{array}{l}\text { Estimated the unit } \\
\text { cost of each } \\
\text { measure } \\
\text { (equipment cost } \\
\text { \& fuel cost } \\
\text { savings) }\end{array}$ & $\begin{array}{l}\text { Co-benefit analysis includes } \mathrm{NOx}, \mathrm{PM}_{10} \text { and } \mathrm{CO}_{2} \\
\text { emission reductions and cost estimations, yielding } \\
\text { cost-effectiveness values for each of the measures. }\end{array}$ & $\begin{array}{l}\text { Climate co-benefit } \\
\text { from air pollution }\end{array}$ \\
\hline $\begin{array}{l}\text { Co-benefits of moving some of the } \\
\text { industrial site of the Teixi district in } \\
\text { Shenyang (Puppim De Oliveira et al., } \\
\text { 2013) }\end{array}$ & $\begin{array}{l}\text { Emissions of air } \\
\text { pollution from } \\
\text { industrial sector } \\
\text { reduced }\end{array}$ & $\begin{array}{l}\text { Improvement of } \\
\text { energy efficiency } \\
\text { and tools }\end{array}$ & Environmental related concerns, not GHG reductions & $\begin{array}{l}\text { Climate co-benefit } \\
\text { from air pollution } \\
\text { control }\end{array}$ \\
\hline $\begin{array}{l}\text { Provide mass public transportation to } \\
\text { reduce congestion in Delhi, India } \\
\text { (Puppim De Oliveira et al., 2013) }\end{array}$ & $\begin{array}{l}\text { Reducing traffic } \\
\text { jams and } \\
\text { increasing public } \\
\text { transport }\end{array}$ & $\begin{array}{l}\text { Reducing fossil } \\
\text { fuel use, CDM } \\
\text { projects }\end{array}$ & GHG emissions and air pollution & $\begin{array}{l}\text { Climate co-benefits } \\
\text { from transport sector } \\
\text { projects }\end{array}$ \\
\hline
\end{tabular}


Indicator of co-benefits can divide into four aspects: (1) environmental concerns (air pollution control, water, and land); (2) health impact; (3) economics and social (efficiency of resources, energy security, jobs creation, poverty, comfort and living condition), and (4) political and institutional.

The guidelines developed by MoE Japan (2009) used three levels of evaluation. The first level is for indicators where data is difficult to evaluate quantitatively and can be expressed qualitatively, e.g. economic stimulation, poverty reduction, and political feasibility. The next two levels is where data can be measured quantitatively using equations and analyse complexity. For example, data in Level 2 might consist of water indicators, such as chemical oxygen demand (COD), $\mathrm{SO}_{2}$, or fossil fuel consumption. The economic value of environmental improvements, or a reduction in waste disposal, is categorised in the third level where equations are more difficult than in the second level. To evaluate co-benefits, the criteria have to address the sustainability of the programmes, project, development goals, political feasibility, social and technical aspect, and environmental goals.

\subsection{Evaluation of the Climate Co-Benefits Programme Implementation}

Chapter 3 and Chapter 4 have reported on three programmes perceived by actors to incorporate climate co-benefit programmes; these being: emission measurement as part of the vehicle validity test; the Trans Metro Bandung; and Paratransits (see Table 6.4). Chapter 5, showed the quality of governance of the public transports (TMB and Paratransit) to be low to moderate. This implies that, from the quality of governance perspective, these programmes suffered from lack of resources, lack of support, and lack of actors involved. However, both public transports have co-benefits with the environment, economic, and social aspect, as reported in Chapter 3 (see Table 3.4). The paratransit, emission test, and TMB have co-benefits for increased fuel economy, reduced spending money (future operating costs), and unravelling congestion. The co-benefits are analysed further here.

Table 6.4: Comparison of the programmes.

Source: Collected data and interview analysis

\begin{tabular}{|c|c|c|c|}
\hline Policy instruments: & Emission measurement & $\begin{array}{l}\text { Trans Metro Bandung } \\
\text { (BRT) }\end{array}$ & Paratransit (angkot) \\
\hline Policy objectives: & $\begin{array}{l}\text { Target: Testing the public } \\
\text { transport and private } \\
\text { vehicles } \\
\text { Purpose: check the } \\
\text { exhaust gas content as per } \\
\text { the specified standard, } \\
\text { check the fuel burning }\end{array}$ & $\begin{array}{l}\text { Target: Bandung } \\
\text { residents or suburban } \\
\text { residents } \\
\text { Purpose: as a mass } \\
\text { rapid transportation } \\
\text { connecting the feeder } \\
\text { to urban fringe, }\end{array}$ & $\begin{array}{l}\text { Target: mostly Bandung } \\
\text { residents } \\
\text { Purpose: as a feeder } \\
\text { connecting the } \\
\text { residence with other } \\
\text { transports mode, reduce }\end{array}$ \\
\hline
\end{tabular}




\begin{tabular}{|c|c|c|c|}
\hline & $\begin{array}{l}\text { conditions of the vehicle, } \\
\text { reduce the air pollution }\end{array}$ & $\begin{array}{l}\text { reduce the use of } \\
\text { private vehicles }\end{array}$ & $\begin{array}{l}\text { the use of private } \\
\text { vehicles }\end{array}$ \\
\hline Actors: & $\begin{array}{l}\text { Implementer: Transport } \\
\text { Department, } \\
\text { Environmental } \\
\text { Management Agency, } \\
\text { Asbekindo } \\
\text { Target: paratransit owners, } \\
\text { TMB operator }\end{array}$ & $\begin{array}{l}\text { Implementer: } \\
\text { Transport } \\
\text { Department, TMB } \\
\text { operator } \\
\text { Target: Bandung } \\
\text { residents and resident } \\
\text { across the border }\end{array}$ & $\begin{array}{l}\text { Implementer: } \\
\text { Paratransit Drivers, } \\
\text { Paratransit Owners, } \\
\text { Cooperatives } \\
\text { Target: Bandung } \\
\text { residents }\end{array}$ \\
\hline Existing condition: & $\begin{array}{l}\text { - The test applies to } \\
\text { public transport in idle } \\
\text { condition } \\
\text { - The regulatory to test all } \\
\text { vehicles (including } \\
\text { private transport) as the } \\
\text { prerequisite of vehicle } \\
\text { license is not yet } \\
\text { enforced. } \\
\text { It is estimated that } \\
1,000 \text { cars/years already } \\
\text { checked the emission } \\
\text { and maintenance. There } \\
\text { are } 54 \text { unit of emission } \\
\text { test workshop in } \\
\text { Bandung }\end{array}$ & $\begin{array}{l}\text { Inaugurated since } \\
2008 \text {, only three } \\
\text { corridors exist ( } 13 \\
\text { corridor as a } \\
\text { planned) } \\
\text { - The shelters } \\
\text { condition is not } \\
\text { well-maintained, } \\
\text { damaged, and most } \\
\text { of it is not used (18 } \\
\text { shelter averages for } \\
\text { every corridor exist) } \\
36 \text { buses with } 664 \\
\text { passengers/day. It } \\
\text { is estimated only } \\
60 \% \text { of passengers } \\
\text { use TMB }\end{array}$ & $\begin{array}{l}\text { - As many as 5.521- } \\
\text { unit paratransit in } \\
\text { Bandung City, it is } \\
\text { estimated only } 30 \\
\text { percent operate } \\
\text { including illegal } \\
\text { paratransit. } \\
\text { In 2017, many } \\
\text { shelters have been } \\
\text { built }\end{array}$ \\
\hline Action Taken & Six months / one year & $\begin{array}{l}\text { Every day }(05.00- \\
20.00) \text {, the current } \\
\text { condition ( } 06.00- \\
18.00)\end{array}$ & $\begin{array}{l}\text { Every day ( } 05.00- \\
20.00) \text {, at certain route } \\
\text { such as terminal route } \\
\text { or market ( } 24 \text { hours) }\end{array}$ \\
\hline Inventory emission & $\begin{array}{l}4 \text { Gas emission analysers } \\
\text { (after services has increase } \\
\text { the } \mathrm{CO}_{2} \text { percentage). }\end{array}$ & $\begin{array}{l}\text { IPCC } 2006 \text { mobile } \\
\text { resources }\end{array}$ & $\begin{array}{l}\text { IPCC } 2006 \text { mobile } \\
\text { resources }\end{array}$ \\
\hline
\end{tabular}

\subsection{The Assessment of Policy Instruments}

Many research studies have measured criteria and ranked programmes (CLG, 2009; Rahman, Paatero, Lahdelma, \& Wahid, 2016; Scarpellini, Valero, Llera, \& Aranda, 2013; Steele, Carmel, Cross, \& Wilcox, 2009). This research adopts a basic rating scale. This checklist of criteria evaluates the quality of elements, and includes a scoring system (Dawson, 2017; MunozRestrepo, 2017). However, the rating uses judgment based on the perception of the meanings of the terms and on the case studies conducted. Six criteria address the co-benefits of policy instruments as specified in Table 6.5 below. 
Table 6.5: Assessment of policy instruments that aim to contribute to mitigation climate change and selected co-benefits.

Source: Collected data and interview analysis, Table is adapted from Dubash et al. (2013) and Ministry of the Environment Government of Japan (2009)

\begin{tabular}{|c|c|c|c|c|c|}
\hline Criteria & & escription* & Vehicle & TMB & Paratransit \\
\hline $\begin{array}{l}\text { Mitigation } \\
\text { Potential }\end{array}$ & GHGs reduction & $\begin{array}{l}\text { Net lower GHG emission } \\
\text { (tones of } \mathrm{CO}_{2} \text { ) }\end{array}$ & 0 & + & + \\
\hline Sustainability & $\begin{array}{l}\text { - Efficiency of } \\
\text { resource use \& } \\
\text { Energy security } \\
\text { - Air }\end{array}$ & $\begin{array}{l}\text { Increased energy } \\
\text { security due to reduction } \\
\text { from fossil fuel demand } \\
\text { The programme has the } \\
\text { strategy to lower air } \\
\text { pollution to the } \\
\text { environment }\end{array}$ & ++ & ++ & ++ \\
\hline $\begin{array}{l}\text { Development } \\
\text { goals }\end{array}$ & $\begin{array}{l}\text { Improving } \\
\text { outcomes for the } \\
\text { poorest }\end{array}$ & $\begin{array}{l}\text { Improve access for public } \\
\text { transport, reduce cost of } \\
\text { transport (public) }\end{array}$ & 0 & + & ++ \\
\hline $\begin{array}{l}\text { Political } \\
\text { Feasibility }\end{array}$ & $\begin{array}{l}\text { Predict the } \\
\text { probable } \\
\text { outcome of a } \\
\text { proposed solution }\end{array}$ & $\begin{array}{l}\text { Examining the actors, events } \\
\text { and environment involved in } \\
\text { all stages of policy (political } \\
\text { support) }\end{array}$ & 0 & + & - \\
\hline $\begin{array}{l}\text { Social } \\
\text { Feasibility }\end{array}$ & $\begin{array}{l}\text { Probability that } \\
\text { the cases would } \\
\text { have to be } \\
\text { accepted }\end{array}$ & $\begin{array}{l}\text { Examining group of } \\
\text { people that are directly } \\
\text { affected (safety) } \\
\text { Reduce congestion, } \\
\text { reduces fatalities, } \\
\text { injuries }\end{array}$ & 0 & + & 0 \\
\hline $\begin{array}{l}\text { Technical } \\
\text { Feasibility }\end{array}$ & $\begin{array}{l}\text { Evaluating project } \\
\text { management and } \\
\text { coordinator }\end{array}$ & $\begin{array}{ll}- & \text { Evaluating system } \\
& \text { performance, data } \\
& \text { availability and quality } \\
\text { - } & \text { Customer support } \\
\text { - } & \text { Security }\end{array}$ & + & ++ & 0 \\
\hline
\end{tabular}

Note: a " + " if it has a positive impact, a " 0 " if it's neutral and "-" if it has a negative impact. The input of the qualitative scores based on the author judgment using the reference from the qualitative and quantitative approach

*as informed in Table 3.4, Chapter 3 regarding original purpose of co-benefits

\subsubsection{Mitigation Potential}

The net lowering of GHG emissions from vehicle emission tests comes from the fuel efficiency in the engine maintenance (OECD, 2002). In Bandung City, every year approximately 1,000 vehicles 
tune-up and take an emission test ${ }^{56}$. This fuel efficiency aims to I reduce the use of gasoline. The emission test and tune-up could reduce the $\mathrm{CO}$ by $23 \%$ and $\mathrm{HC}$ by $50 \%$. However, it will increase $\mathrm{CO}_{2}(106 \%)^{57}$. This outcome makes the vehicles emission test to be considered as neutral. One researcher suggested driving techniques (eco-driving) can influence fuel efficiency by as much as 30 percent (Andrieu \& Pierre, 2014; Arokiaraj \& Banumathi, 2014; Ferreira, De Almeida, \& Da Silva, 2015; Funazaki, 2012). In Bandung City, the privately owned cars have a $23 \%$ mode share, whereas the share of the publicly owned minibus is only $4-5 \%$. The highest percentage of mode share comes from the privately owned motorcycles at around 65-70\% (Bappeda, 2013).

The TMB and Paratransit have a positive impact on lowering GHG emissions. The TMB ridership only exists in three corridors in Bandung City. This BRT ridership is equal to 1,200 ridership/day (60\%) and equal to 10.8 million ridership/year as predicted for 2019 (Nugroho \& Zusman, 2015). The cumulative length of TMB constructed would be $20 \mathrm{~km}$. This TMB is different from other forms of BRT, such as Jakarta or Palembang, because separate road lanes do not yet exist.

The paratransit still use gasoline as their main fuel. Only a few paratransits use gas. The paratransit trajectory has 39 service areas that cover lengths varying from $8 \mathrm{~km}$ to $24 \mathrm{~km}$. The load factor of paratransit is $36.6 \%$. This public transport mode only has a share of $23 \%$ from all of the transport mode services. The capacity of ridership/year is between $1.53-1.87$ million ridership. However, the real ridership only shares one a third of this capacity because of low service performance.

The use of public transport will also lead to the use of active transport. As part of active transport, non-motorised transport (NMT) can be used to improve mobility with its flexibility and affordability. For instance, bicycles have a significant role in the Netherlands. The NMT plays a crucial role in mobility of people, not only in the cities, but also in rural areas. In Asia, e.g. China, Indonesia and Philippines, the NMT has been promoted as the strategy to reduce the use of private vehicle use (Joewono \& Kubota, 2005; Koizumi, Nishimiya, \& Kaneko, 2013; Tiglao, 2007). Research has shown the benefits of the shift from car use to active transport use (i.e., bicycles) can deliver health benefits and reduce air pollution (De Nazelle et al., 2011; Rabl \& de Nazelle, 2012; Sener \& Reeder, 2014).

The paratransit function as the feeder of the TMB, and walking or cycling as part of the activities when using public transport, has encouraged the Bandung City government to evolve paratransit design so they can carry bicycles. Cycling policy, as part of the thematic day (every Friday), is arranged in a handbill form for simple steps for the internal local government employee. The provincial government followed this positive local government action by establishing free areas for motorised vehicles, such as in Gedung Sate (the official building for the West Java Province)

\footnotetext{
${ }^{56}$ Based on interview with Head of Asbekindo (2017)

${ }^{57}$ The data from Asbekindo (2017)
} 
and Balaikota. However, although this policy has been valid since October 2013, it worked only temporarily ${ }^{58}$.

\subsubsection{Sustainability}

Transport sector vehicle fuel consumption has become one criterion to develop. Sustainable energy is one indicator of energy security that has five aspects: availability, affordability, accessibility, acceptability, and sustainability. This criteria has co-benefits linked to the availability of energy supply and sustainability.

All programmes have a primary goal to reduce energy use and maintain energy sustainability. Thus, these have a positive impact on sustainability. The vehicle emission testing and inspection programme helps vehicles improve engine performance by reducing inefficient combustion (Moglia \& Marquez, 2002). The use of public transport, such as paratransit and TMB, reduces the use of private transport. This could reduce energy use. These are expected to reduce congestion in Bandung City. However, as the survey showed, paratransits, as a public transport service, themselves became the cause of traffic jams (see Chapter 7).

The vehicle emission test that commonly analyses the carbon monoxide (CO), hydrocarbon ( $\mathrm{HC})$ and carbon dioxide $\left(\mathrm{CO}_{2}\right)$ from the vehicle exhaust helps lead to improved efficiency of car engines by reducing inefficient combustion and calibrating the engine (Kuwahara, de Kievit, Shladover, Zhang, \& Barth, 2013). However, fuel demand will continue to increase in most countries, unless additional intervention can reduce fuel demand by a shift to more fuel-efficient or low emission vehicles (OECD, 2002).

TMB will use electrical bus as a zero-carbon strategy to reduce emissions. The TMB still use diesel fuel but the development of fuel injection system technology has helped them become more efficient in fuel consumption. Data from Table 6.4 calculates the TMB energy consumption of $74.03 \mathrm{TJ} /$ year and total annual GHG emissions equal to 53,413 tons/year. This translated to 4.95 kg GHG emission/ridership/year.

Paratransit energy consumption is about $309.74 \mathrm{TJ} /$ year leading to GHG emissions of 21,987 tons/year; equivalent to $11.76 \mathrm{~kg} \mathrm{GHG}$ emission/ridership/year. Paratransits have started using fuel injection burning system since 2000 instead of combustion system using a carburettor. Procurement arrangements for each vehicle specification to use for public transport in Bandung are unclear and are left to each paratransit cooperative to organise.

Government owns the TMB and apply rules in each region concerning fuel efficiency. The vehicle emission test has a large influence on improving energy efficiency, if after the test's efforts are made to improve combustion. However, such improvements for paratransits, especially engine

58 In 2015, the parking area can be used by vehicles 
combustion, are left to each paratransit owner. To date, the TMB programme has more influence on reducing energy use than the paratransit programme. However, in the future, if the vehicle emission test includes vehicle maintenance as a matter of course, then this effort will help increase energy use improvement in these other programmes.

\subsubsection{Development Goals}

The programmes are obliged to serve communities with transport services. There are two aspects to improve outcomes for the poorest: (1) reduced cost of transportation; (2) improved access to the programmes.

The first aspect is related to the ability of the consumer to pay for their travel modes. The data collected shows TMB is the cheapest transport mode as, for one corridor (20 km distance), passengers only spend Rp.5.000 (equal to 38 cents US ${ }^{59}$ ). For the same distance, paratransit passengers can travel two or three routes. The price varies depending on distance. The vehicle emission test is only indirectly related to improving outcomes for the poorest in as much as this test has the ability to improve their fuel efficiency.

Paratransit public transport aids access as it has higher service coverage (works as a feeder). The paratransit route is generally located on a connecting road (collector) to a provincial or national road. The TMB route is located on the provincial or national roads. There is no relationship between improving access for the poorest here with the vehicle emission test. The vehicle emission test is conducted mainly for those who have the opportunity to use their own transport mode.

\subsubsection{Political, Social, and Technical Feasibility}

All programmes serve the Bandung citizen with public transport services. The previous chapter has analysed the actors, events, and environment involved in all stages of policy instruments (Chapter 3, 4, 5). The results of previous chapters have shown that the political feasibility is more relevant to the TMB and emission test. Thus, the paratransit programme is often neglected by the influence of local levels.

To be socially accepted, all programmes have to meet the standard stipulated by the government and the evaluation of the target users, especially for the safety and performance. However, another aspect to consider is how these programmes have the ability to reduce congestion and reduce fatalities and injuries. Chapters 3, 4, 5 and 7 shows how respondents were aware of the public need to maintain paratransits as part of their travel mode. However, a low quality of governance, and unfair competition from other transport modes (app-based transportation, motorcycle, and buses) has left paratransits in a poor condition. Nevertheless, all aspects of quality of governance have shown a positive collaboration for the TMB programme. The local

${ }^{59}$ Exchange rate of currency: 1 US\$ equal to Rp. 13.108 (2016) 
government was able to maintain and develop this mode of transport. The vehicle emission test here has contributed to climate change mitigation and improving environmental quality, even thought they are less prioritised by the community.

Technical feasibility, as a criterion for co-benefits, was evaluated by assessing the performance system, data availability and quality, customer support, and security. The TMB and Paratransit (as reported in Chapter 4 and 5) were low in performance. The paratransits, particularly, had the worst technical feasibility due to a low quality of maintenance and inspection. The vehicle emission test is used as a reference for driving feasibility, but has a few drawbacks, such as a lack of awareness of urban transport to conduct the vehicle tune-up and by not being required to be included in the test for the vehicle registration certificate (STNK).

\subsection{Conclusions}

The case study assessment has allowed us to evaluate policy instruments and categorise the criteria. The qualitative and quantitative approach answers how the programmes meet the criteria of co-benefits. However, in comparing programmes, we need to explain how to rank the results objectively.

The co-benefits approach results are more relevant to the public transport. The TMB has the highest value because this programme meets all of the criteria of co-benefits approach. The paratransit has the positive value on the criteria of mitigation climate change, energy and environmental sustainability, and development goals. The vehicle emission test has the lowest feasibility (the criteria of sustainability and technical feasibility). 
Chapter 7: Vehicle Users Attitudes and Behaviour Concerning Climate Change Policies and Travel Choice Mode

\subsection{Introduction}

People are aware of the threat of global warming. This issue is how nations tackle this, particularly industrial countries (Watson et al., 2001). The developing countries face the problem globally and at the level of local issues (Nemet et al., 2010). Local government has to deal with the problem of deteriorating air quality in the cities alongside climate change mitigation issue. This has been illustrated in the transport sector by the massive and increasing use of motorised vehicles that have caused serious problems for the environment and the quality of life.

Our survey of willingness to change travel modes Stern's Theory of Environmental Significant Behaviour (Stern, 2000). This was intended to answer the research question on how climate change mitigation programmes initiated by government were acknowledged by the stakeholders and organised. The survey addressed three questions: first, to understand respondent's knowledge and preferences, specifically with respect to local transport problems and the global issue of climate change; second, to compare attitudes amongst users of private vehicles and public transport; and, finally, questions related to the low carbon transport programme as part of climate change mitigation policy. The target group was private vehicles users with an ability to use also public transport.

Earlier chapters considered programmes intended to mitigate climate change that targeted private vehicle users preferences potentially to use more on public transportation. This chapter addresses the fifth research question as to how actor's perspective consider climate policies and influence their choice of travel mode. Individual behaviour and attitude were assessed to see how great a potential there was to support climate change policy and travel mode preferences. Several descriptive statements and variables explore their intentions, including their attitudes, personal capabilities, contextual factors (external forces), and also their habits or routine activities influencing their frequency of using travel modes. Socio-demographics also influenced their intentions or environmentally significant behaviour.

\subsection{Objectives of this study}

The objective of this survey was to find out how the Bandung citizens perceive their travel mode choices, and the willingness to change in using public transportation. The study set out to find correlation among exogenous variables (e.g. socio-economic variables) and endogenous variables (e.g. attitudinal, personal capabilities, contextual factors, and habit) as described in the theoretical framework given in Chapter 2. 
The study also considered links between user attitude and opinions toward low carbon transport policies and the user's preference about the global and local problems. Low carbon policies aimed to reduce the use of private vehicles and involved tax increases, fuel increments, and raising parking fee. User preference at the global problem level considered their views on climate change. For attitudes to local problems, the questionnaire sought respondent's responses on air quality, the increased use of public transportation, and their perception of the sources of traffic congestion.

A primary hypothesis of this study was the expectation of a positive relationship between the travel mode choice of vehicle users with their perception of lowering GHG emissions and achieving selected co-benefits. Other findings expected included: (1) a negative relationship between vehicles users with their perception of GHG emission issues and policies to mitigate the climate change; and (2) a positive relationship between socio-economic characteristic (gender, age, level of education, expenditure) with the travel behaviour and environmental significant behaviour.

\subsection{Methodology}

The quantitative method used a survey with non-probability sampling (purposive). The sampling targeted private vehicle users (cars or motorcycle) at places (spread out from the city centre to the urban fringe) where they would also have access to and an opportunity to use public transportation alternatives (paratransit, bus or online applications). The survey targeted private vehicle users from offices, markets or malls, schools, universities, and residential areas. The availability of urban transport facilities at the respondent's location became the main consideration in choosing the sampling site. This sampling was in accordance with the purpose of research as stated.

The respondent who completed questionnaires included: employees (50\%) i.e. government employees, state-owned or regional-owned enterprise employees, and private employees; students (25\%); housing residents and others (25\%). The selection and location of interviews were based on their activities (works, study, residence) and ranged from the city centre to their dwelling place. Another judgement applied used the high ratio of vehicle volumes to road capacity (V/C) and high air pollution based on congestion (Bappeda, 2013; BPLH, 2013). The data was collected from face-to face-survey. The length of interviews ranged between 4-7 minutes per respondents. To avoid non-responses, the questionnaires were made as short and simple as possible. Small incentives may have increased the response rate. The sample size targeting Bandung City residents was $\mathrm{N}=250$.

Total vehicles (cars and motorcycles) in Bandung City were around 1.17 million in 2016. Roscoe in Hill (1998) set out sample size rules as follows:

1. The sample used should range between 30 to 500 respondents 
2. In multiple regression as part of multivariate research, the sample size should be at least ten times larger than a number of variables

3. Generally, choice of sample size is as much a budgetary consideration, as it is statistical consideration.

Data were collected from September to October 2016 through field survey. The survey achieved a response rate of $84 \%(\mathrm{~N}=211)$. A pilot initial survey tested the questionnaire design to allow revision to reduce ambiguity. The questionnaire consisting of three parts: (1) personal information; (2) trip information (habit); and (3) attitudes and contextual factors (supportive policies).

The data were processed using the SPSS statistic tool (IBM Corp, 2010) and used non-parametric analysis (The Spearman rank-order correlation coefficient) as the data were ordinal from Likert scale (de Winter \& Dodou, 2010). The Spearman correlation is a nonparametric measure of the strength and direction of association that exists between two variables with the confidence level of 0.05 and 0.01 . Statistical descriptors for the frequencies of data and crosstabs analyses were used to explain the data. In terms of sufficient data and yield stable solution, the research used bivariate analysis (Myers, Ahn, \& Jin, 2011; Osborne \& Costello, 2005).

\subsection{Results}

The descriptive statistics in Table 7.1 show that the sample of respondents represented a balanced proportion between male and female gender, while the percentage of married respondents was almost twice the single respondents. The information also added by a large number of family members and occupations (more than $70 \%$ respondents have jobs and only $25 \%$ students). These ranges helped the original purpose of the research to seek a good understanding of vehicle user's perception on lowering GHG emissions and their willingness to change their travel modes.

The respondent reported information revealed monthly expenditure from more than $60 \%$ of respondents spends Rp. 2 million or more ${ }^{60}$. Almost $30 \%$ had monthly expenditure in the range of Rp. 3 million to 5 million. Household income levels are indicated by reported household expenditure. These income levels are important in determining people's travel behaviour (Mcgrath, Hine, \& Gunay, 2007). Several household expenditure surveys have reported the percentage of expenditure on transport (BPS Provinsi Jawa Barat, 2016; EEA, 2011). This expenditure comprises several components, including: transport services, purchase of vehicles, and operational costs. These items, when surveyed, are classified as non-food consumption (BPS Provinsi Jawa Barat, 2016).

${ }^{60}$ Exchange rate of currency: 1 US\$ equal to Rp. 13.108 (2016) 
Table 7.1: Descriptive statistic of respondent's socio-economic characteristic (exogenous variables)

\begin{tabular}{|c|c|c|}
\hline Exogenous variables & \multicolumn{2}{|c|}{ Characteristics (211 respondents) } \\
\hline Gender & Male (124); Female (87) & \\
\hline Marital Status & Single (77); Married (126) & \\
\hline $\begin{array}{lll}\text { Number of } & \text { Family } \\
\text { Members } & & \end{array}$ & $\begin{array}{l}\text { One (12); } \\
\text { Two (27); } \\
\text { Three (40); }\end{array}$ & $\begin{array}{l}\text { Four (64); } \\
\text { Five (41); } \\
\text { More than six (23) }\end{array}$ \\
\hline Age (years) & $\begin{array}{l}\text { Less than } 20(25) ; \\
21-30(62) ; \\
31-40(54) ;\end{array}$ & $\begin{array}{l}41-50(31) ; \\
51-60(34) ; \\
\text { More than } 60(5)\end{array}$ \\
\hline Level of Education & $\begin{array}{l}\text { Below high school (22); } \\
\text { High school (56); } \\
\text { Diploma D1/D2/D3 (14); }\end{array}$ & $\begin{array}{l}\text { Bachelor or D4 (92); } \\
\text { Graduate or above (27) }\end{array}$ \\
\hline Household expenditure ${ }^{61}$ & $\begin{array}{l}\text { Less than Rp. } 1.000 .000(16) ; \\
\text { Rp. } 1.000 .000 \text { - Rp. } 1.499 .999(25) \text {; } \\
\text { Rp. } 1.500 .000 \text { - Rp. } 1.999 .999(26) \text {; } \\
\text { Rp. } 2.000 .000 \text { - Rp. } 2.999 .999(34) \text {; }\end{array}$ & $\begin{array}{l}\text { Rp. } 3000.000 \text { - Rp. } 4.999 .999 \text { (60); } \\
\text { Rp. 5.000.000 - Rp. 7.499.999 (27); } \\
\text { Rp. 7.500.000 - Rp. } 9.999 .999(10) ; \\
\text { More than Rp. } 10.000 .000(4)\end{array}$ \\
\hline Bike ownership & Do not have (117); one bike (53); t & wo bikes (31); more than two (10) \\
\hline
\end{tabular}

\subsubsection{Socio-Demographic Variables}

Respondents generally owned two vehicle types: motorcycles (92) and cars (9). More than $50 \%$ of respondents owned both (110. Table 7.2 shows the gender ownership balance was remarkably similar and $52 \%$ of men and women owner both a car and a motorcycle. Nearly all respondents (202) owned motorcycles. This was also reflected in driving license ownership where 153 respondents had motorcycle licenses.

${ }^{61} 1$ US\$ equal to Rp. 13.108 (2016) 
Table 7.2: Gender distribution and possession of driver license in private vehicle ownerships ${ }^{62}$

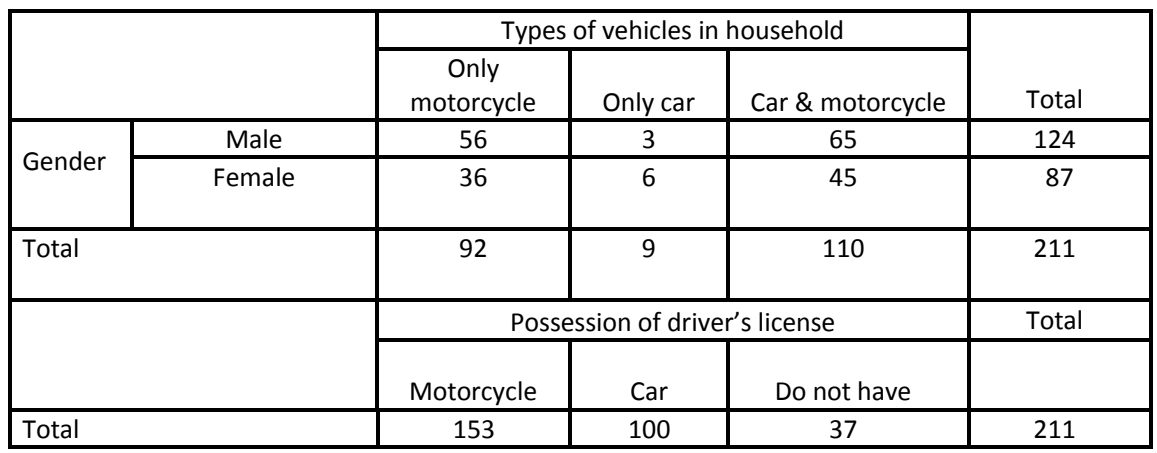

The use of particular travel modes was assessed by considering the frequency of use of existing means of transportation in a day or less ${ }^{63}$. Table 7.3 shows that more than $80 \%$ of respondents used a motorcycle daily as their travel mode. More than $50 \%$ of respondents did not use public transport (angkot and TMB), bicycle, or mobile application for their daily activities. Travel mode by bus was the least used transport (70\%).

Private vehicles users (car and motorcycle) considered the frequency of use of their vehicles from more than once a day to never using the vehicle ${ }^{64}$. For daily activities, the use of a car and motorcycle were the most used travel modes. Use of public transport (paratransit 'angkot' and bus) and mobile application are an alternative solution for the private vehicle users to use as their travel mode choice. However, the survey showed more than $50 \%$ of the private vehicles owner never used public transport, bike, or mobile application. In essence, respondent's travel mode tends to be with the vehicles they own.

Table 7.3: Frequency of using travel mode

\begin{tabular}{|l|c|c|c|c|c|c|}
\hline \multirow{2}{*}{ Status } & \multicolumn{5}{|c|}{ Frequency (amount) } \\
\cline { 2 - 7 } & Car & Motorcycle & $\begin{array}{c}\text { Paratransit } \\
\text { (angkot) }\end{array}$ & $\begin{array}{c}\text { Bus } \\
\text { (TMB) }\end{array}$ & Bike & $\begin{array}{c}\text { Uber, Grab or } \\
\text { GO-JEK }\end{array}$ \\
\hline More than once a day & 33 & 114 & 15 & 4 & 4 & 5 \\
\hline Once a day & 32 & 56 & 7 & 2 & 5 & 3 \\
\hline Three or four times a week & 5 & 7 & 3 & 2 & 4 & 0 \\
\hline Once or twice a week & 32 & 10 & 18 & 5 & 20 & 14 \\
\hline Twice a month & 15 & 5 & 14 & 10 & 18 & 7 \\
\hline
\end{tabular}

\footnotetext{
62 The private vehicle owners were based on the family household; The private vehicle users do not reflect the ownership

${ }^{63}$ Calculated from vehicle usage of each activity. It is possible in a day to travel to several places or in just one week only use vehicle on the weekend.

${ }^{64}$ Travel more than once a day is assumed as more than one travel destination
} 


\begin{tabular}{|l|c|c|c|c|c|c|}
\hline $\begin{array}{l}\text { Less than once a month } \\
\text { (once or twice in two } \\
\text { month) }\end{array}$ & 19 & 8 & 41 & 40 & 28 & 38 \\
\hline Never & 75 & 10 & 112 & 146 & 131 & 142 \\
\hline Total & 211 & 210 & 210 & 209 & 210 & 209 \\
\hline
\end{tabular}

The research looked for correlations between the frequency of use of vehicles and sociodemographic variables, i.e. marital status, age, income level (represented by expenditure), occupation, and education level. Cross-tabulation between the age and frequency of car and motorcycle use, the data only showed correlation for the frequency of car users. This was a weak negative correlation (Spearman's Rho=-.246, Sig.000, N=211). The correlation between car ownership and frequency of using mobile application users (Uber, Grab or GO-JEK) was also a weak negative correlation ((Spearman's Rho= -.199, Sig.004, N=209). Another weak positive correlation existed between different age and the frequency of public transport users (paratransit: Spearman's Rho=.187, Sig. 0.007, N=210; and Bus: Spearman's Rho=.319, Sig. 0.000, $\mathrm{N}=209$ ) and mobile application users (Spearman's Rho=.365, Sig. 0.000, N=209).

Several studies have highlighted differences in the travel pattern of different age groups involving young people, adults, and older people (Golob \& Hensher, 1998; Scheiner \& Holz-Rau, 2007). This likely occurs, as they are each involved in different types of activities. The cross-tabulation of age and the use of cars shows the age range of 21-40 years used cars more often than any other category of age (see Table 7.4).

Table 7.4: Age and frequency of using car cross-tabulation

\begin{tabular}{|c|c|c|c|c|c|c|c|c|}
\hline \multirow[b]{2}{*}{ Age } & \multicolumn{8}{|c|}{ Frequency of car use } \\
\hline & $\begin{array}{c}\text { more } \\
\text { than } \\
\text { once a } \\
\text { day }\end{array}$ & $\begin{array}{r}\text { once } \\
\text { a day }\end{array}$ & $\begin{array}{c}\text { three or } \\
\text { four } \\
\text { times a } \\
\text { week }\end{array}$ & $\begin{array}{c}\text { once } \\
\text { or } \\
\text { twice } \\
\text { a } \\
\text { week }\end{array}$ & $\begin{array}{c}\text { twice } \\
\text { a } \\
\text { month }\end{array}$ & $\begin{array}{l}\text { less than } \\
\text { once a } \\
\text { month }\end{array}$ & never & Total \\
\hline $\begin{array}{c}\text { less } \\
\operatorname{than} 20\end{array}$ & 4 & 0 & 1 & 0 & 3 & 7 & 10 & 25 \\
\hline $21-30$ & 7 & 7 & 0 & 11 & 4 & 6 & 27 & 62 \\
\hline $31-40$ & 8 & 6 & 2 & 10 & 3 & 4 & 21 & 54 \\
\hline $41-50$ & 5 & 8 & 2 & 4 & 2 & 0 & 10 & 31 \\
\hline $51-60$ & 7 & 11 & 0 & 6 & 3 & 2 & 5 & 34 \\
\hline $\begin{array}{c}\text { more } \\
\text { than } 60\end{array}$ & 2 & 0 & 0 & 1 & 0 & 0 & 2 & 5 \\
\hline Total & 33 & 32 & 5 & 32 & 15 & 19 & 75 & 211 \\
\hline
\end{tabular}


For the auto-oriented 65 respondents, the use of angkot generally was a "rudimentary level of comfort (e.g. narrow access, small benches, and no-air-conditioning)" (Syabri, Pradono, \& Soegijanto, 2013, p. 7). The vehicle inspection rules for public transport has three aspects regulating the safety of public transport as follows: (1) technical; (2) legal; and (3) health ${ }^{66}$. Most paratransit users from a survey in three cities in Indonesia reported negative experiences and dissatisfaction regarding the riding safety and driving skills of the paratransit drivers (Joewono, Tarigan, \& Susilo, 2016).

The survey showed all these aspects were generally poorly managed. Technically, most vehicles neglected passenger safety belts, handgrips, or tyre conditions. Health-wise, owners often failed to meet health requirements, such as physical driver compliance (i.e. working time and rest schedules) and competency (driver behaviour). The frequency of daily car use (see Table 7.4 column "more than once a day" and "once a day") applied to one-third of the total respondents. Other data showed a similar percentage (for once or twice a week). Respondents frequently used their cars at weekends (mostly family or married respondents). There was a correlation between respondent married marital status and the frequency of using a car (Spearman's Rho=-.151, sig. $0.032, n=203$ ). However, there are no differences between respondent's marital status and the frequency of their using a motorcycle.

Married person obviously have family member who will use vehicles that carry more people. Other research shows $65 \%$ of changing car ownership is associated with child birth, offspring reaching driving age, and adults joining the households (Clark, Lyons, \& Chatterjee, 2016).

Table 7.5 shows the frequency of car us by a married person was 85 out of 126 married respondents (67\%). For the single status respondent, 44 respondents used the car less than the married person (57\%). The proportion of married respondents was more than the single status in using the car.

Besides variable of age, gender, and marital status, other exogenous variables (educational background, occupation, number of family member, and the household expenditure) showed

\footnotetext{
${ }^{65}$ The statement that asked the respondents has travel patterns, which in Javid (2017) could be categorized as auto-oriented (prefer using cars or motorcycle) and transit-oriented (using a public transport or nonmotorized transport)

${ }^{66}$ According to the Regulation of Directorate General of Land Transportation No. 523/AJ.402/DRJD/2015 regarding Guidelines for the implementation of traffic safety inspection and road transport for public transportation
} 
some different results and correlation with the frequency of travel mode. This data was treated as an ordinal data, even though some data, such as the number of family members, was in numerical order (see Table 7.5).

Table 7.5: Marital status and frequency of using car cross-tabulation

\begin{tabular}{|c|c|c|c|c|c|c|c|c|}
\hline & \multicolumn{8}{|c|}{ Frequency of car use } \\
\cline { 2 - 10 } & $\begin{array}{c}\text { more } \\
\text { than } \\
\text { once a } \\
\text { day }\end{array}$ & $\begin{array}{c}\text { once } \\
\text { a day }\end{array}$ & $\begin{array}{c}\text { three or } \\
\text { four } \\
\text { times a } \\
\text { week }\end{array}$ & $\begin{array}{c}\text { once } \\
\text { or } \\
\text { twice } \\
\text { a } \\
\text { week }\end{array}$ & $\begin{array}{c}\text { twice } \\
\text { a } \\
\text { month }\end{array}$ & $\begin{array}{c}\text { less than } \\
\text { once a } \\
\text { month }\end{array}$ & never & Total \\
\hline Single & 10 & 7 & 1 & 8 & 8 & 10 & 33 & 77 \\
\hline Married & 20 & 23 & 4 & 22 & 7 & 9 & 41 & 126 \\
\hline Total & 30 & 30 & 5 & 30 & 15 & 19 & 74 & 203 \\
\hline
\end{tabular}

Education levels have proven influential on travel behaviour in previous research. This has shown that individuals with higher levels of education use active travel (walking) more significantly than those with a lower level of education (Ajzen, 2010; Farag et al., 2003; Kaklamanou, Jones, Webb, \& Walker, 2015). This generalisation is perhaps debatable given the specific countries the research conducted in. Research of public transport (paratransit) by Joewono \& Kubota (2007) showed that the larger the family size, the more loyal people are. Large families seem to choose the mode of transport that keep transport expenses as low as possible. However, research from developing countries shows the strong consciousness of social status, while a private vehicle is also often regarded as a status symbol. Even if public transport services are of a high standard of service, the majority of people (vehicles owner) will travel by private transport. The members of car-owning families tend to use other forms of individual public transport, such as on-line transport, rather than a paratransit or bus TMB when the car was used by another family member (Iles, 2005, p. 27).

The correlation between educational status, number of family members, and expenditure with the frequent travel mode is shown in Table 7.6 below. All correlation found was either very weak or weak. Educational status did correlate with travel modes of a car, motorcycle, bike, and mobile application. The number of family members only correlated with the travel mode of Bus (TMB). In addition, expenditure has correlated with travel mode of car, paratransit, and bike. The Bus (TMB) is more significant than other travel modes for its frequency of use. Transport mobile application required knowledge of handheld devices that supported the online service. 
Table 7.6: Spearman correlation of socio-demographic and frequent travel mode

\begin{tabular}{|c|c|c|c|c|c|c|}
\hline \multirow{2}{*}{$\begin{array}{c}\text { Socio- } \\
\text { Demographic }\end{array}$} & \multicolumn{6}{|c|}{ Frequent travel mode } \\
\hline & Car & Motorcycle & $\begin{array}{c}\text { Paratransit } \\
\text { (angkot) }\end{array}$ & Bus (TMB) & Bike & $\begin{array}{c}\text { Mobile } \\
\text { application } \\
\text { (GRAB, GO-JEK) }\end{array}$ \\
\hline $\begin{array}{l}\text { Educational } \\
\text { Status }\end{array}$ & $\begin{array}{c}\text { Spearman } \\
\text { Rho: -.346; } \\
\text { sig.0.000; } \\
\mathrm{N}=\mathbf{2 1 1}\end{array}$ & $\begin{array}{c}\text { Spearman } \\
\text { Rho: 0.280; } \\
\text { sig. 0.000; } \\
\mathrm{N}=\mathbf{2 1 0}\end{array}$ & $\begin{array}{l}\text { Spearman } \\
\text { Rho: -.046; } \\
\text { sig. 0.509; } \\
\quad \mathrm{N}=210\end{array}$ & $\begin{array}{l}\text { Spearman } \\
\text { Rho: -.063; } \\
\text { sig. 0.361; } \\
\mathrm{N}=209\end{array}$ & $\begin{array}{l}\text { Spearman } \\
\text { Rho: - } \\
.136 ; \\
\text { sig.0.048; } \\
\mathrm{N}=\mathbf{2 1 0}\end{array}$ & $\begin{array}{c}\text { Spearman Rho: } \\
\text {-.185; sig.0.007; } \\
\text { N=209 }\end{array}$ \\
\hline $\begin{array}{l}\text { Number of } \\
\text { family } \\
\text { member }\end{array}$ & $\begin{array}{l}\text { Spearman } \\
\text { Rho: -.036; } \\
\text { sig. 0.608; } \\
\quad \mathrm{N}=207\end{array}$ & $\begin{array}{l}\text { Spearman } \\
\text { Rho: } 0.100 ; \\
\text { sig. } 0.153 ; \\
\mathrm{N}=206\end{array}$ & $\begin{array}{l}\text { Spearman } \\
\text { Rho: -.043; } \\
\text { sig. 0.542; } \\
\text { N=206 }\end{array}$ & $\begin{array}{c}\text { Spearman } \\
\text { Rho: -.199; } \\
\text { sig.0.004; } \\
\text { N=205 }\end{array}$ & $\begin{array}{c}\text { Spearman } \\
\text { Rho: - } \\
.134 ; \text { sig. } \\
0.056 ; \\
\text { N=206 }\end{array}$ & $\begin{array}{c}\text { Spearman Rho: } \\
\text {-.002; sig. } \\
0.981 ; N=205\end{array}$ \\
\hline Expenditure & $\begin{array}{c}\text { Spearman } \\
\text { Rho: -.380; } \\
\text { sig.0.000; } \\
\text { N=202 }\end{array}$ & $\begin{array}{l}\text { Spearman } \\
\text { Rho: 0.086; } \\
\text { sig. 0.224; } \\
\quad \mathrm{N}=201\end{array}$ & $\begin{array}{c}\text { Spearman } \\
\text { Rho: 0.149; } \\
\text { sig.0.035; } \\
\text { N=201 }\end{array}$ & $\begin{array}{c}\text { Spearman } \\
\text { Rho: } \\
\text { 0.174; } \\
\text { sig.0.014; } \\
\text { N=200 }\end{array}$ & $\begin{array}{c}\text { Spearman } \\
\text { Rho: } \\
0.019 ; \text { sig. } \\
0.785 ; \\
\text { N=201 }\end{array}$ & $\begin{array}{c}\text { Spearman Rho: } \\
\text { 0.094; sig. } \\
\text { 0.187; N=200 }\end{array}$ \\
\hline
\end{tabular}

Comparing occupation and motorcycle use produced similar results across the sample as Table 7.7 shows. More than $60 \%$ respondents used motorcycles and only 10 respondents did not use this travel mode to support their daily activities.

Table 7.7: The occupation and frequency of using motorcycle

\begin{tabular}{|c|c|c|c|c|c|c|c|c|}
\hline & \multicolumn{8}{|c|}{ Frequency of using motorcycle } \\
\hline & $\begin{array}{c}\text { more than } \\
\text { once a } \\
\text { day }\end{array}$ & $\begin{array}{l}\text { once } \\
\text { a day }\end{array}$ & $\begin{array}{c}\text { three or } \\
\text { four } \\
\text { times a } \\
\text { week }\end{array}$ & $\begin{array}{c}\text { once or } \\
\text { twice a } \\
\text { week }\end{array}$ & $\begin{array}{l}\text { twice a } \\
\text { month }\end{array}$ & $\begin{array}{c}\text { less than } \\
\text { once a } \\
\text { month }\end{array}$ & never & Total \\
\hline Student & 26 & 15 & 3 & 4 & 1 & 2 & 1 & 52 \\
\hline $\begin{array}{l}\text { Government \& } \\
\text { State-owned } \\
\text { employee }\end{array}$ & 40 & 24 & 3 & 5 & 2 & 4 & 7 & 85 \\
\hline $\begin{array}{l}\text { Private } \\
\text { employee }\end{array}$ & 15 & 8 & 0 & 1 & 1 & 0 & 1 & 26 \\
\hline Entrepreneur & 15 & 2 & 1 & 0 & 0 & 0 & 1 & 19 \\
\hline Others & 18 & 7 & 0 & 0 & 1 & 2 & 0 & 28 \\
\hline Total & 114 & 56 & 7 & 10 & 5 & 8 & 10 & 210 \\
\hline
\end{tabular}


Educational background did not relate to the use of paratransit or buses. However, the use of paratransit and a bus was unfamiliar to almost all respondents. It was interesting to note the correlation of the variation of family members against the frequency of using a bus as public transportation. The different categories of household expenditure from respondents also correlated with the use of travel mode, especially car and public transport, such as paratransit and bus.

\subsubsection{Travel Priorities}

The survey also captured the respondent desires on the use of private vehicles and public transportation. The factors that contributed, as revealed by several studies, include functional attributes, time factors, cost, and other attributes of service quality (Ashraf, Okamura, \& Nakamura, 2015; Beirão \& Sarsfield Cabral, 2007; Eriksson, Nordlund, \& Garvill, 2010; Gärling \& Schuitema, 2007; Redman, Friman, Gärling, \& Hartig, 2013; Scheiner \& Holz-Rau, 2007; Tarigan, Susilo, \& Joewono, 2014; Van, Choocharukul, \& Fujii, 2014). These factors applied to our study as well, but only four attributes were dominant as perceived by respondents.

Figure. 7.1 illustrates that the primary reasons people use public transport are for speed of service and the aspects of safety and comfort (37\% and $33 \%$ ). This is for $45 \%$ of respondents having household expenditures more than Rp. 3 million ${ }^{67}$. However, the respondents also considered cost (8\%) and obstacles in having a private vehicle (8\%) as important. The latter issue does not apply to motor vehicles because of the ease of access to available finance. The respondent perceived that public transport has the co-benefit in reducing traffic congestion (6\%). Cleanliness and contributing to a better environment were only reported by $4 \%$ and $1 \%$, respectively. Other reasons reported included people having problems with their private vehicles (broken down).

671 US\$ equal to Rp. 13.108 (2016) 


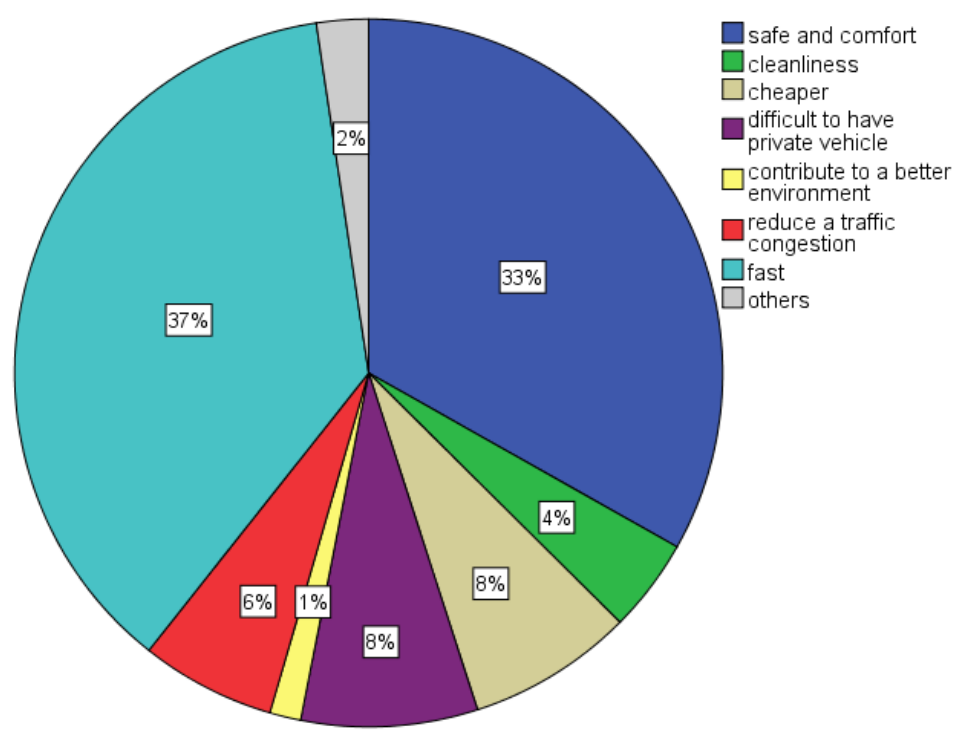

Figure 7.1: The respondent reasons in using public transport

Respondent also highlight the flexibility of public transport to accommodate many carry on items, compared to the restrictions faced by the motorcycle's limited capacity.

The main crucial priority reasons for people to use their private vehicle are shown in Figure 7.2 and were promptness (fast) or travel time reliability (57\%). Given Bandung's daily traffic congestion problem, this result is hardly surprising choice in selection of travel mode. Motorcycle use is the easiest and cheapest way to deal with traffic congestion in Bandung City. Safety and comfort (19\%), were important secondary factors. Previous survey data from Bandung City showed citizens were aware that public transportation received less attention in safety and comfortable factor (Bappeda, 2013). 


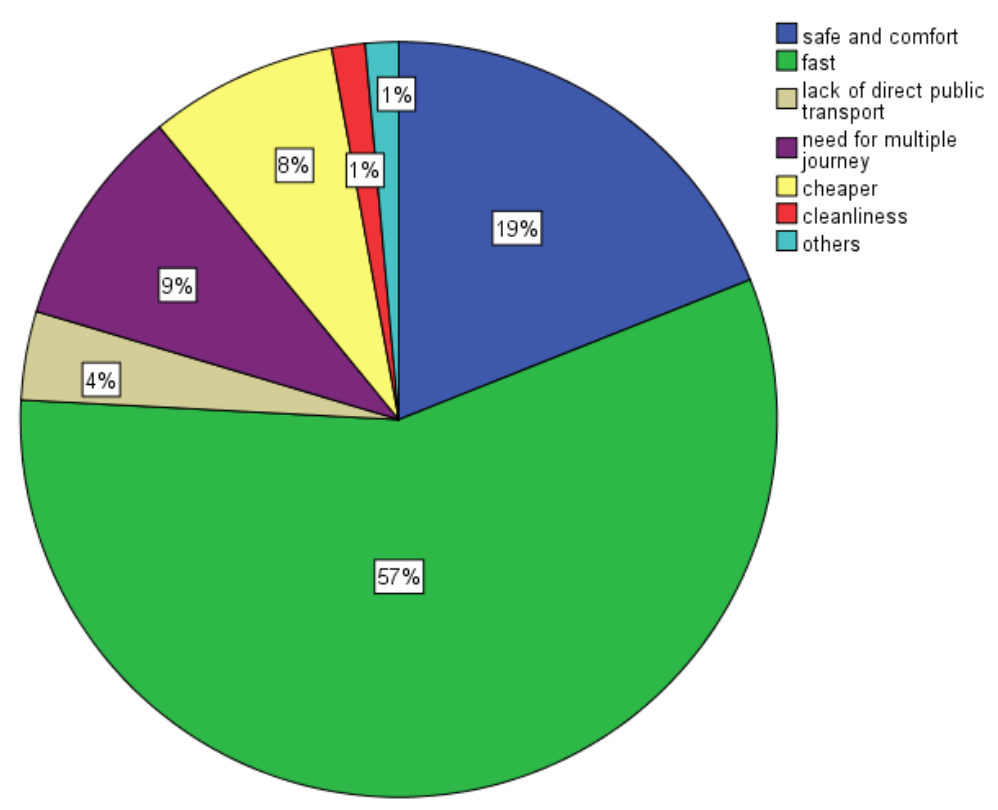

Figure 7.2: The respondent reasons in using private vehicles

Respondents feelings about the source of congestion focused on the role of paratransit (angkot). They were accused as being the common source of congestion, followed by the role of private vehicles users. Respondents felt uncomfortable with the high numbers of private vehicles on the highways. The role of motorcycles, cars parked on roads, undisciplined riders and drivers of motor vehicles and street vendors were also seen as sources of congestion. Finally, some respondents associated congestion with the length of traffic light time and the Bus (TMB) operations. 


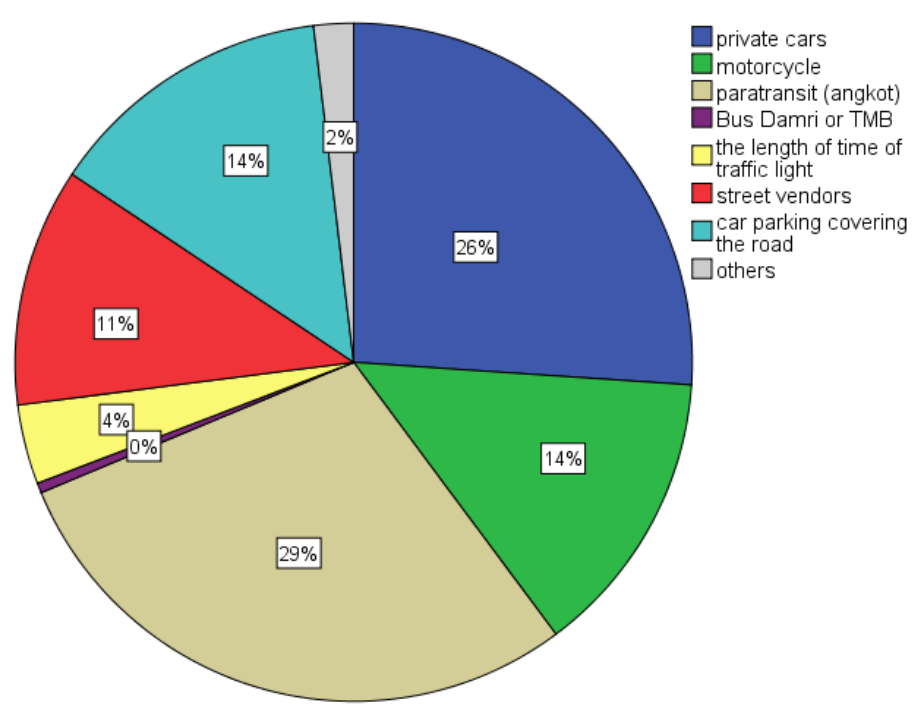

Figure 7.3: Source of congestion based on respondents

\subsubsection{User preferences on policy instruments and perceptions regarding GHG}

Respondents were asked three types of questions as analysed in Table 7.8. First, there were questions concerning global and local knowledge on climate change and air pollution. Second, there were questions on attitude and preferences on using public transport and private vehicles; travel mode habits were addressed by different questions. Finally, there were questions on transport policy and low carbon transport governance.

Table 7.8: The statement concerning attitude and intention of environmentally significant behaviour

\begin{tabular}{|l|l|c|}
\hline No. & Statement & Abbreviated \\
\hline 1 & The global climate change is not the main problem to deal with & P1 \\
\hline 2 & The congestion is a local problem that one should deal with & P3 \\
\hline 3 & The transport sector is a source of climate change in the urban area & P4 \\
\hline 4 & The public transport is a tool to reduce climate change & P5 \\
\hline 5 & \begin{tabular}{l} 
I am willing to use low emission public transport to reduce air pollution \\
\hline 6
\end{tabular} & $\begin{array}{l}\text { I am willing to use private vehicles, even if the public transport offers the } \\
\text { shorter time }\end{array}$ \\
\hline 7 & $\begin{array}{l}\text { I prefer to use public transport even if must walk longer (more than } 400 \\
\text { meters) }\end{array}$ & P7 \\
\hline
\end{tabular}




\begin{tabular}{|l|l|c|}
\hline 8 & It is not possible to use public transport if there is a lot of travel destination & P8 \\
\hline 9 & $\begin{array}{l}\text { The tax that I paid to develop the public transport helps to reduce the air } \\
\text { pollution }\end{array}$ & P9 \\
\hline 10 & $\begin{array}{l}\text { The government needs to increase the parking fee to reduce the use of } \\
\text { private vehicles and encourage the use of public transport }\end{array}$ & P10 \\
\hline 11 & $\begin{array}{l}\text { The government needs to increase the price of gasoline to reduce the use of } \\
\text { private transport }\end{array}$ & P12 \\
\hline 12 & Paratransit (angkot) helps as a solution to reduce the climate change & P13 \\
\hline 13 & Bus (TMB) helps as a solution to reduce the climate change & P13 \\
\hline
\end{tabular}

The respondents mostly disagreed with the first statement (60\%) as seen in Figure 7.4 and were aware that global climate change is an issue to address. Less than $25 \%$ thought global issues were not a main problem that needed to be solved.

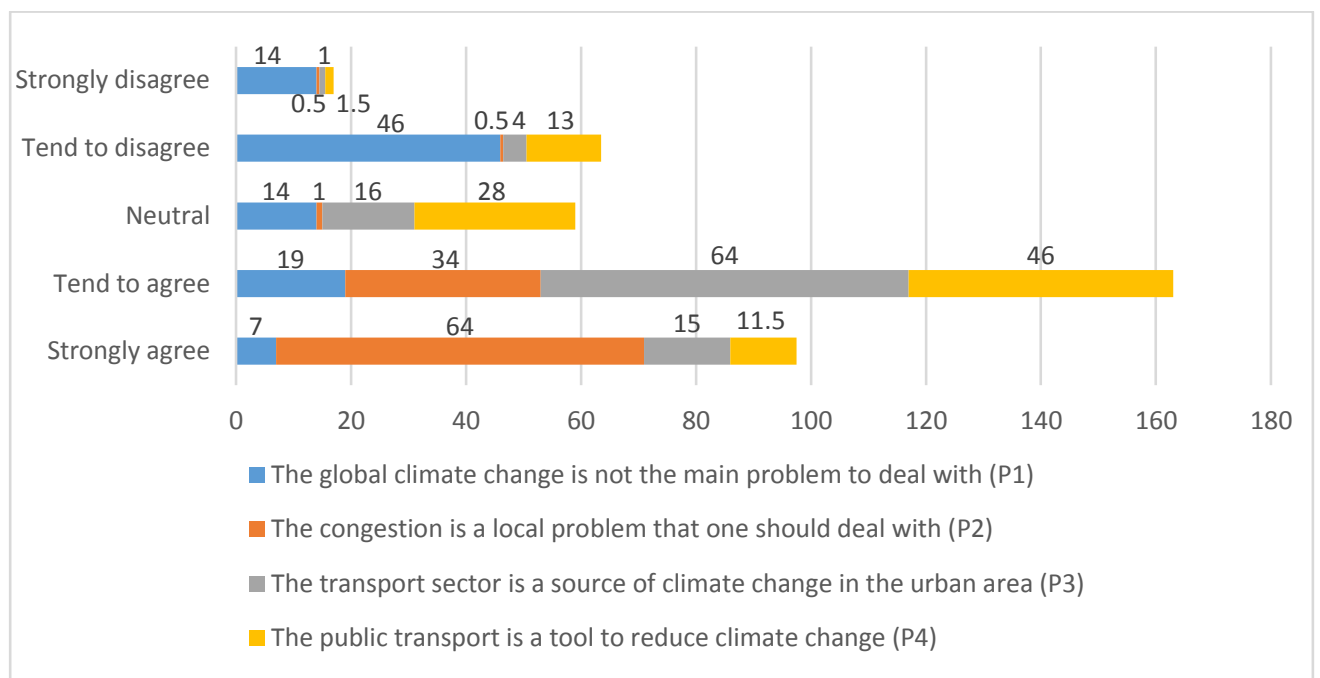

Figure 7.4: The valid frequency (\%) of respondent's perception of global and local problems

When respondents asked about local issues (P2), particularly the daily traffic congestion, most respondents strongly agreed (98\%) that this issue needed to be tackled. Car and motorcycle users agreed that their travel mode contributed to the traffic congestion and needed improvement.

$79 \%$ of respondents agreed, while $5 \%$ disagreed, that the transport sector was a source of global climate change in urban cities (see Fig. 7.4 on the P3 statement). There are $16 \%$ of respondent choose the neutral option and hesitate to decide whether they think favourably or negatively toward an item. 
However, this statement only informs the general views on the transportation sector. Furthermore, the information from the respondents about the types of transportation sector that contribute to the climate change is still unclear. Therefore, the research addressed the inquiry to get the information regarding how the users' views about the potential of public transport in tackling the climate change (see Figure 7.4 on the P4 statement). Almost $60 \%$ of respondents agreed and less than $15 \%$ of the sample disagreed that public transport could reduce climate change.

The paratransit 'angkot' public transport has a 10-year vehicle age limit. This policy on vehicle feasibility is related to environmental management of technology to reduce GHG emissions from transport. Most cars manufactured today release far less $\mathrm{CO}_{2}$ than cars produced a decade ago (Chapman, 2007; Department for Transport, 2004).

Only two from the four questions on climate change and the transport sector were correlated. The correlation exists between P3 and P4. This was significant but weak (Spearman's Rho $=0.299$, $\mathrm{N}=211$, Sig. 0.01 ). Overall, the respondents believed that the global climate change was the main problem to be solved.

Vehicle users then were asked about their perception of transport policies, such as tax, parking fee, and gasoline prices. Then, there were questions on their attitude and preferences to using travel modes (See Figure 7.5). The categories are public transport oriented (P5 and P7) and private vehicles oriented (P6 and P8).

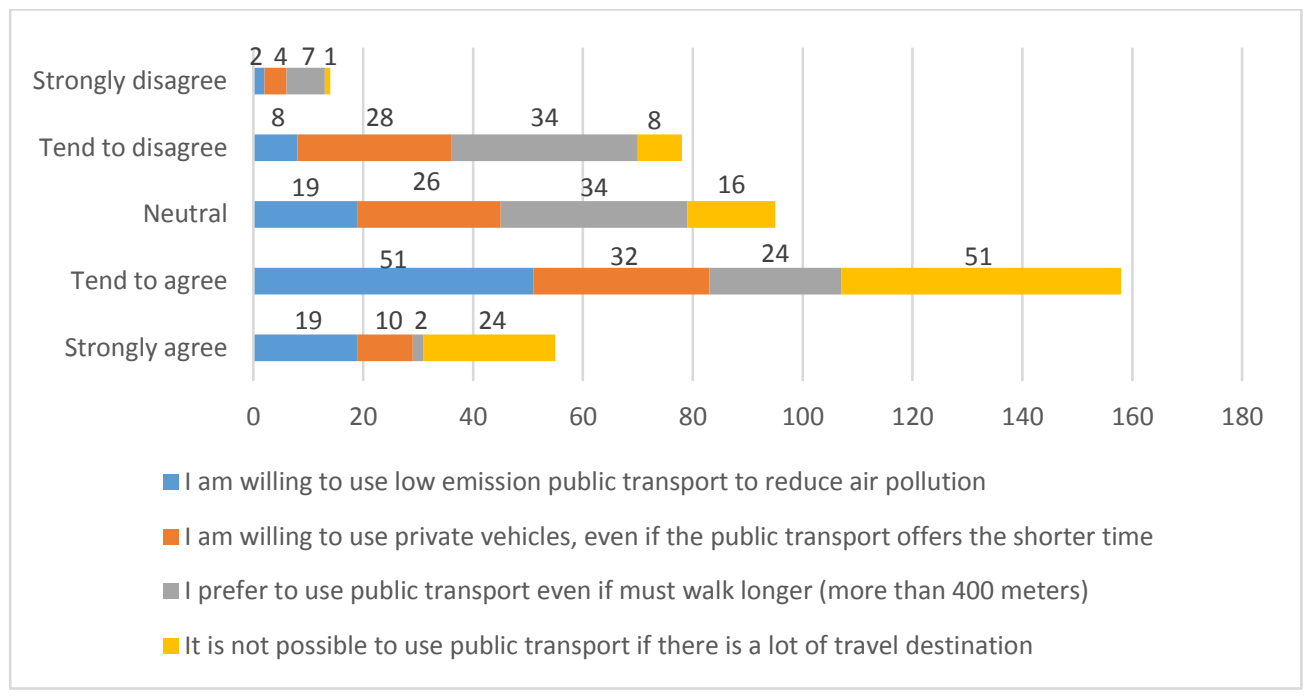

Figure 7.5: The valid frequency (\%) of attitude towards public transport and private vehicles 
$70 \%$ of respondents agreed they were willing to use public transport as it released low emission and could reduce air pollution (P5). However, when compared with the use of private vehicles, even if the public transportation offered shorter travel times, $42 \%$ respondents chose to use the private vehicles and only $32 \%$ chose to use the public transport. The respondents also tended to still use their private vehicles, if there was an option of using the public transportation, but they have to walk further. Only $26 \%$ chose to use the public transportation mode. More respondents were neutral for the statement on willingness to use public transportation if they had to walk further to the bus stop or station.

Given the range of places people visit, the use of private vehicles was more desirable. They tended to use the private vehicles because of the need for multiple journeys (see Figure 7.2 previously). In conclusion, most people chose not to use public transportation to support their daily activities in Bandung City.

Table 7.9: Correlation between the willingness to use of private vehicles compare to the public transport

\begin{tabular}{|l|l|l|l|l|l|}
\hline Statement & Correlation & P5 & P6 & P7 & P8 \\
\hline $\begin{array}{l}\text { I am willing to use low emission } \\
\text { public transport to reduce air } \\
\text { pollution (P5) }\end{array}$ & $\begin{array}{l}\text { Coefficient } \\
\text { Sig. (2-tailed) }\end{array}$ & 1.00 & -.127 & $0.205^{* *}$ & $-.198^{* *}$ \\
\hline I prefer to use private vehicles, & Coefficient & -.127 & 1.00 & -.065 \\
even if the public transport offers & Sig. (2-tailed) & 0.065 & & 0.004 \\
the shorter time (P6) & $\mathrm{N}$ & 211 & 211 & 211 \\
\hline I am willing to use public transport & Coefficient & $0.205^{* *}$ & $-.198^{* *}$ & $0.228^{* *}$ \\
even if must walk longer (more & Sig. (2-tailed) & 0.003 & 0.004 & 1.00 & 0.001 \\
than 400 meters) (P7) & $\mathrm{N}$ & 211 & 211 & 211 & 211 \\
\hline It is not possible to use public & Coefficient & $-.198^{* *}$ & $0.228^{* *}$ & $-.214^{* *}$ & 1.00 \\
transport if I there is a lot of travel & Sig. (2-tailed) & 0.004 & 0.001 & 0.002 & 211 \\
destination (P8) & $\mathrm{N}$ & 211 & 211 & 211 & 211 \\
\hline
\end{tabular}

Note: ${ }^{* *}$ correlation is significant at the 0.01 level (2-tailed)

Table 7.9 shows that correlation occurred between P5 and P7, as well as with P8. Correlation also occurred between P6, P7, and P8. In brief, P7 and P8 correlated to all statements. All correlations were very weak (.00-.19) and weak condition (.20-.39). The correlation between P5 and P7 showed high awareness and P6 and P8 less awareness or environmental friendliness. A negative coefficient existed between P5 and P8, between P6 and P7, and between P7 and P8. The results suggest a high ranking for the use of low emission public transport (P5), but was the lowest ranked for P8 and vice versa. A positive correlation occurred for between P6 and P8.

The survey can conclude that respondents still use and tend to use their own private vehicles, even if public transport offers advantages of shorter travel time. A similar condition exists for respondent's use of their private vehicles as they have multiple journeys. These result accord 
with research from other developing countries where cultural factors, such as status, determine how society uses various travel modes (Golob \& Hensher, 1998; Iles, 2005).

The questions on transportation policies focused on the three policies approach (or push measures) using economic instruments to reduce the use of private transport as part of sustainable transport or low carbon transport objectives. Taxation to develop public transport, raising parking fees, and gasoline fee increments are policies that the public are aware of. However, these policies remain on paper, except for the gasoline fee (Bappeda, 2013; Dinas Perhubungan, 2015). The main purpose is to reduce the use of private vehicles and lower GHG emissions. Other question assess how respondents appreciate the role of public transportation as a solution for the low carbon policy (especially paratransits and buses).

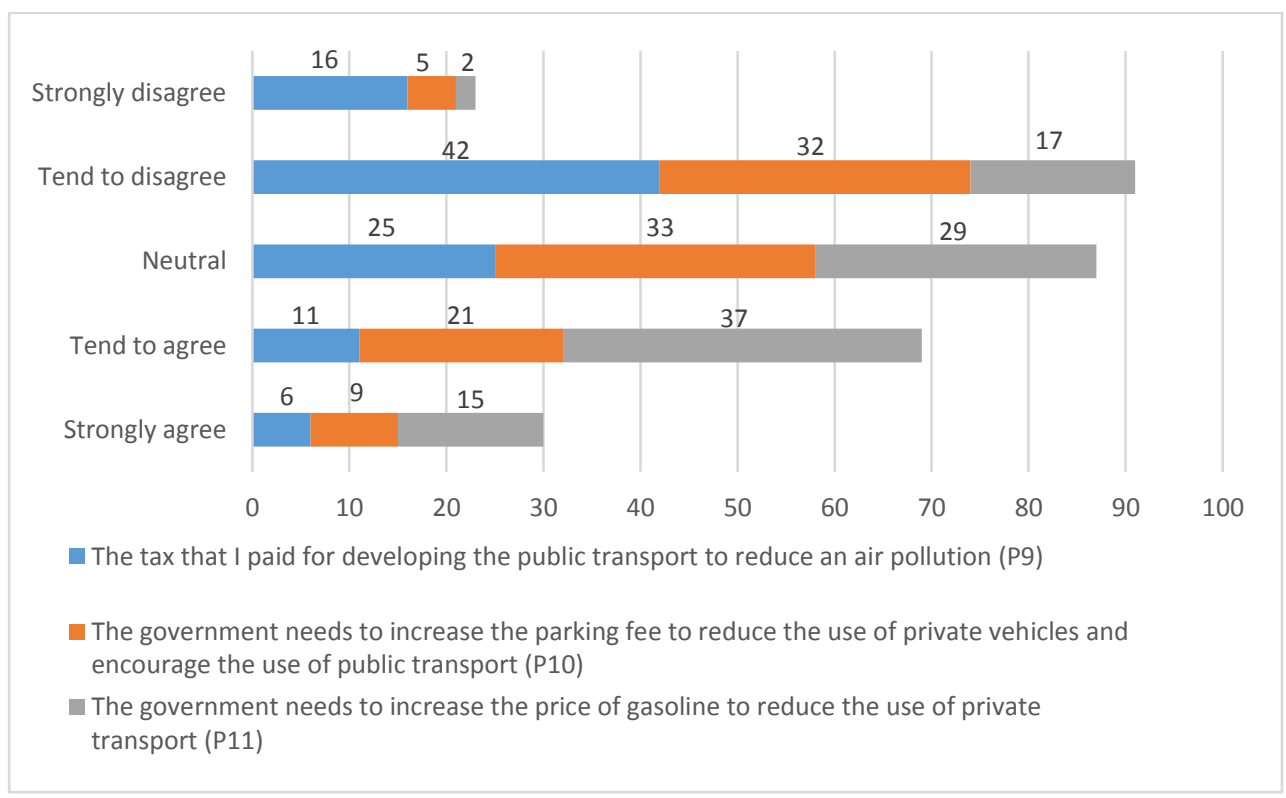

Figure 7.6: The valid frequency of attitude towards transport policy measures

Figure 7.6 shows that respondents did not prefer the use of the tax instrument and raising parking fee to lower air pollution and better manage climate change respectively (58\% and $37 \%$ ). However, a fuel tax increase to reduce the use of private vehicles was agreed to by more than half of the respondents. In Indonesia, the amount of subsidised gasoline has been reduced since 2014. In terms of mitigation of climate change, the use of biodiesel has become a priority for the future. Gasoline prices recently have been referred to market mechanisms. However, increased gasoline price will reduce people's purchasing power, not only for gasoline, but also for other basic materials and poor people will be influenced by this policy (Harefa, 2015). 
Table 7.10: Correlation between the low carbon transport policies

\begin{tabular}{|c|c|c|c|c|}
\hline Statement & Correlation & P9 & P10 & P11 \\
\hline $\begin{array}{l}\text { The tax that I paid for developing the } \\
\text { public transport to reduce an air pollution } \\
\text { (P9) }\end{array}$ & $\begin{array}{l}\text { Coefficient } \\
\text { Sig. (2-tailed) } \\
\mathrm{N}\end{array}$ & $\begin{array}{l}1.00 \\
211\end{array}$ & $\begin{array}{l}0.408^{* *} \\
0.00 \\
211\end{array}$ & $\begin{array}{l}0.134 \\
0.051 \\
211\end{array}$ \\
\hline $\begin{array}{l}\text { The government needs to increase the } \\
\text { parking fee to reduce the use of private } \\
\text { vehicles and encourage the use of public } \\
\text { transport (P10) }\end{array}$ & $\begin{array}{l}\text { Coefficient } \\
\text { Sig. (2-tailed) } \\
\mathrm{N}\end{array}$ & $\begin{array}{l}0.408^{* *} \\
0.00 \\
211\end{array}$ & $\begin{array}{l}1.00 \\
211\end{array}$ & $\begin{array}{l}0.581^{* *} \\
0.00 \\
211\end{array}$ \\
\hline $\begin{array}{l}\text { The government needs to increase the } \\
\text { price of gasoline to reduce the use of } \\
\text { private transport (P11) }\end{array}$ & $\begin{array}{l}\text { Coefficient } \\
\text { Sig. (2-tailed) } \\
\mathrm{N}\end{array}$ & $\begin{array}{l}0.134 \\
0.051 \\
211\end{array}$ & $\begin{array}{l}0.581 * * \\
0.00 \\
211\end{array}$ & $\begin{array}{l}1.00 \\
211\end{array}$ \\
\hline
\end{tabular}

**. Correlation is significant at the 0.01 level

*. Correlation is significant at the 0.05 level

Not all of the statements in Table 7.10 show correlation with each other. The tax (P9) and a parking fee (P10) showed moderate correlation (Spearman's Rho $=0.408$; sig $=.00$ ) and significant at the level 0.01 . Moderate correlation (Spearman's Rho $=0.581$; sig $=.00$ ) occurred between increasing parking fees (P10) and fuel increments (P11).

Other insights on respondent's opinions to public transport as a solution for tackling climate change were: (1) the use of paratransit (angkot); and (2) the use of TMB bus (see Table 7.17). People willing to use public transports were more likely to support policies aimed at reducing greenhouse gas emissions (Golob \& Hensher, 1998; Greene, D.L; Wagener et al., 1997; Lee \& Van De Meene, 2013). Policy makers should be advised on appropriate policies for the development of public transport as a priority (Pongthanaisawan \& Sorapipatana, 2010). 


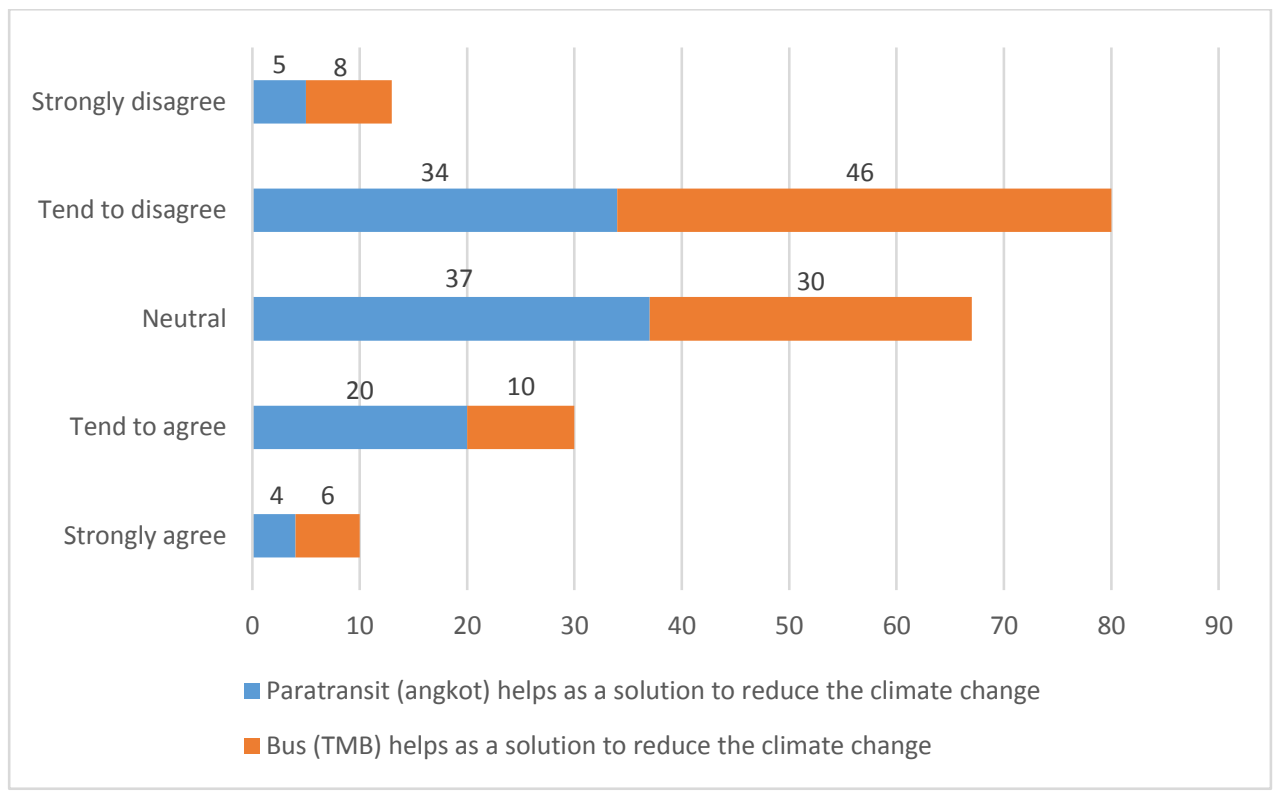

Figure 7.7: The valid frequency of attitude towards public transport as a solution to climate change mitigation

A majority expressed their opinion that the Paratransit and Bus (TMB) would not be the solution to reduce the climate change. More than one-third of the respondents choose a neutral position. This option can be described as 'don't know' or neither of 'agree' or 'disagree' (Sturgis, Robert, \& Smith, 2014). The moderate correlation (Spearman Rho 0.478) between two statements was significant at the 0.01 level. The use of public transport did not attract the private vehicle owners such that it would become their travel mode.

Comparing the intervention statements (taxes (P9), parking fee (P10), and fuel price (P11)) with other previous statements showed some weak correlation (Spearman's Rho $=-.250$, sig. $=0.00$, $\mathrm{N}=211$ ) between taxing to increase public transport and reduce the congestion (P9) with public transport as a tool to reduce climate change (P4). Another weak correlation occurred between the increase of parking fee to reduce private vehicles (P10) with public transport to reduce congestion (P4) (Spearman's Rho $=-.252$, sig. $=0.00, \mathrm{~N}=211$ ).

Correlation existed between variables from different groups. For instance, it existed among the respondent's willingness to use low emission of public transport (P5) with all of the policies (taxes (P9), parking fee (P10), and fuel price (P11)). All this correlation was weak (taxes Spearman's rho= -.222 , sig. $=0.001, \mathrm{~N}=211$; parking fee Spearman's rho=-.259, sig. $=0.000, \mathrm{~N}=211$; and fuel price Spearman's rho $=-.232$, sig. $=0.001, \mathrm{~N}=211$ ). A correlation occurred between the acceptances to use public transport, even if they must walk, with the increase of fuel price to reduce private 
vehicle use (Spearman's rho=-.322, Sig. $=0.000, \mathrm{~N}=211$ ). Correlation also existed between not using public transport if there are many travel destination with increased parking fee to reduce private vehicles and the increased fuel price, respectively (Spearman's rho $=.196$, Sig. $=0.004$, $\mathrm{N}=211$ and Spearman's rho $=.169$, Sig. $=0.014, \mathrm{~N}=211$ ).

To use public transport as a solution and reduce climate change, there was a correlation between paratransit 'angkot' solutions to lower GHG emissions with all policies interventions (taxes (P9) Spearman's rho=.281, Sig. $=0.000, \mathrm{~N}=211$; parking fee $(\mathrm{P} 10)$ Spearman's rho $=.306$, Sig. $=0.000$, $\mathrm{N}=211$; and fuel price ( $\mathrm{P} 11)$ Spearman's rho $=.252$, Sig. $=0.000, \mathrm{~N}=211$ ). The Bus public transport also correlated with all of the policy interventions (taxes (P9) Spearman's rho $=.293$, Sig. $=0.000$, $\mathrm{N}=211$; parking fee (P10) Spearman's rho $=.354$, Sig. $=0.000, \mathrm{~N}=211$; and fuel price (P11) Spearman's rho $=.191$, Sig. $=0.005, \mathrm{~N}=211$ ). Similarly, another correlation existed with public transport as a solution to reduce the climate change with the paratransit "angkot" solution to lowering GHG emissions (Spearman's rho=-.289, Sig. $=0.000, \mathrm{~N}=211$ ) and the bus 'TMB' as a solution to lowering GHG emissions (Spearman's rho=-.312, Sig. $=0.000, \mathrm{~N}=211$ ).

\subsection{Discussion}

The aim of this study was to apply concepts from environmental significant behaviour to Bandung citizens, particularly as to how they perceived their travel mode choices between public transport and private vehicles, and their willingness to change and use public transport. Another objective was to compare existing policies to lower GHG emissions and other co-benefits (see Chapter 3, table 3.4).

The study sampling was targeted to try and reflect the overall conditions and characteristics people across Bandung in terms of gender, age, private vehicle user, users attributes and monthly expenditure. The data were collected from questionnaires with an $84 \%$ response rate across a representative sample with a majority of private vehicles users located where public transport routes traversed their areas. A pilot survey was conducted to validate the questionnaire and to address content validity to answer the study objectives. There was no intervening strategy or planned behaviour planned for the respondents (Jimmieson, Peach, \& White, 2008; Steg \& Vlek, 2009; Stern et al., 1999).

We can conclude that the use of travel mode is, to a considerable degree, dependent on vehicle ownership patterns. For instance, car and motorcycle owners correlated with their use of their own private vehicles. If policies reduced the ease of access to private vehicles; it could reduce the use of this transportation mode. However, car users tend to auto-orientate as more than $50 \%$ of respondents did not use public transport as their travel mode, even if government improved public transport. The majority of respondents used motorcycles as their daily activities, followed by car vehicles.

This result is associated with the ease by which a person can purchase a vehicle, particularly motorcycles. The results remain incomplete, as the influence of commuters located in the urban 
fringe of Bandung City was not investigated further. These commuters impact on reducing GHG emission Golob \& Hensher, (1998). Other strategies to reduce GHGs at regional or local level are to improve fuel efficiency and increase transit accessibility (Zahabi, Miranda-Moreno, Patterson, Barla, \& Harding, 2012).

There was no significant correlation between gender and a vehicle's ownership. In terms of age and status, correlation existed with the use of cars, but not with the use of motorcycles. As predicted, the data showed that educational background does not relate to the use of public transport (paratransit and bus). The different types of household expenditure also correlated with the use of travel mode, especially cars and public transportation, such as paratransit and bus. The richer respondents with higher expenditure pattern were more reliant on cars, while respondents with lower incomes used public transport.

People's habits were represented by the frequency of use of each travel mode. The results were mixed with socio-demographic variables, such as the use of private vehicles that correlated with educational background. Household expenditure correlated with the frequency of using cars, paratransits, and buses. Even though respondents rarely used the bus and bike, it has become more significant than other travel modes.

The use of mobile application software required knowledge of how to use a smartphone and being capable of installing the application. Generally, educational background was connected with the use of this apparatus. The results have shown that students and those with bachelor degree use this application more often than others. The invention of smartphones with application that embed travel mode choice have been developed by the transportation companies. These have transformed the mobility of citizens by giving them a real-time service and knowledge of current traffic condition. The positive impact of this innovation has triggered efficiency that is reflected in economic, social, and environmental aspects (Shaheen, Cohen, Zohdy, \& Kock, 2016). The results show the use of a mobile application, such as GO-JEK and Grab, were related to car ownership. There could be psychological resistance (Tertoolen, Kreveld, \& Verstraten, 1998) where the habit of using private vehicles will continue because the use of a mobile application has a similar principle as using private vehicles. The vehicles that use a ridesharing application are private vehicles.

Although many factors were considered by respondents for their use of private and public vehicles, only two were dominant for the use of public transport: promptness (fast) and safety (comfort). As such, these are the two prerequisites that must be performed by public transport (Beirão \& Sarsfield Cabral, 2007). Lower fares and barrier to using private vehicles, particularly car ownership, were secondary issues. The environmental co-benefits derived from the use of public transportation contributing to better environmental outcomes, whilst also reducing traffic congestion and air pollution. However, these results only were selected in less than $6 \%$ of cases. 
These priorities stand as the crucial factors for $56 \%$ of cases and reflect the daily problems people face in Bandung, i.e. traffic congestion and a lack of public transport service.

Respondents saw paratransits, cars, and motorcycles as being the main cause of traffic congestion. The majority of respondents chose parked cars as the biggest source of congestion. Many citizens in Bandung City preferred online-based transportation, such as GO-JEK, Grab, and Uber where the use of private vehicles for passenger transport was accepted as being safer, cleaner, and cheaper than existing public transport. These factors reflect the preference factors stated for public transport; safety and comfort.

The use of online-based transportation mirrors the developing technology of Android and other smartphones. Their ubiquitous use, integrated with GPS, payment systems, and feedback mechanisms, help ride-sharing company, such as Uber or Grab, to develop their business in transportation (Wallsten, 2015). The new sharing economy of ride-sharing services is creating new competition for existing transport service companies. However, this expansion is burdening road demand where it is already saturated. Despite this, these innovations also bring mechanism for resources management that can improve efficiency. This can benefit providers, users, and society (Teubner, 2015).

To limit the global and local issue of environmental impact of private transport in urban areas is not straightforward. The study highlights how important these issues were to the respondents, who also agreed that the transport sector was a source of global climate change. This psychological contribution is significant in the contribution it could make to reducing the magnitude of climate change, as it points to the opportunity to improve understanding of relevant human behaviours to drive climate change and human reactions to adopt climaterelated technologies and policies (Stern, 2011).

There is a link between the transport sector as a source of climate change with the use of public transport that could reduce the climate change (Spearman's Rho $=0.299$; sig. $=0.00$ ). The results show that the knowledge, information, and people awareness regarding environmental impact, and also the use of public transportation, would not be the right indicator to reduce the environmental impact of private cars. This was also articulated by Green Alliance who pointed out that there has to be an approach and action beyond delivering information (Collins et al., 2016). As they cited, "Information does not necessarily lead to increased awareness, and increased awareness does not necessarily lead to action. Information provision, whether through advertisements, leaflets or labelling, must be backed up by other approaches" (Collins et al., 2016, p. 46). The frequency of private vehicle use related to past behaviour is an important aspect of habits that have formed. These influence goal-directed behaviour from the past and for the future. The present research showed that the intention to use public transport was very low compared to using private vehicles, even though the scenario actions have tried to provide comfort to public vehicles (see Table 7.9). It is also possible to use cognitive dissonance 
(inconsistent thought, beliefs, or attitudes) to motivate drivers to decrease their private vehicle use. However, it remains difficult to decrease private vehicles use (Tertoolen et al., 1998).

Four statements represent respondent's attitudes towards public transportation and private vehicles (see Table 7.9). They can be categorised as auto-oriented and transit-oriented (Javid, 2017). However, these do not share the same proportions of car and motorcycle users, as most car owners also have a motorcycle in their household. Respondents who owned cars and motorcycles sometimes used their entire transport mode within a week. The result shows the tendencies to use private vehicles, even if public transport offers some convenience and comfort. In addition, if respondents must travel to several places, the majority will definitely use a private vehicle. These observations confirm the intention to use private vehicles is strongly and more related to habit (Stern, 2000) than attitudinal factors (Eriksson, 2008; Eriksson et al., 2010), as seen on the Theory of Planned Behaviour (Ajzen, 1991).

Nevertheless, comparing these results with the transit-oriented shows a different pattern. The first statement encourages the respondent to use the public transportation with an intention to reduce local air pollution. The second statement goes further, if the respondent was willing to be an active transport users (walking) more than $\mathbf{4 0 0}$ meters. The respondents offered no impact on their travel behaviour; even the respondents were already aware and concerned about traffic congestion as a serious problem. This result is contrary to the previous study that citizen's individual experience of environmental pollution might restrain their use of a car to help deliver an environmental benefit (Bamberg et al., 2011; Scheiner \& Holz-Rau, 2007; Stern et al., 1999).

Although the focus has been on individual attitudes and knowledge, the policies on transport aspects should not be disregarded. Respondent's intentions towards transport policies, especially push policies ${ }^{68}$ (taxes, increased parking prices, and fuel increments) can have an effect on the lowering GHG emissions. Acceptability of these push policies varied, although more respondents disagreed with the use of tax and increase of a parking fee. The lack of social acceptability and political support has been the cause of the less than actual application of push measures (Khademi, Timmermans, \& Borgers, 2014).

To understand why certain policies are acceptable, it was important to examine the circumstances. According to Gärling \& Schuitema (2007), both factors of low carbon transport policies and personal characteristic were important for acceptability. As predicted, the majority of respondents were motorcycle users and these policies would be burdensome for vehicles users. However, the increase of fuel prices was deemed to not be a burden because the expense of using private vehicles for the motorcycle types was considered to be cheaper than urban public

\footnotetext{
${ }^{68}$ Two types of travel demand management: push measures (i.e. raising the cost or tax) and pull measures (improving the public transport or alternative travel options) (Creutzig et al., 2012; Eriksson, 2008; Eriksson et al., 2010; Pardo, 2010)
} 
transport ${ }^{69}$. Individual characteristics, such as being a car user and one's occupation (job), were correlated with tax policies and the increase of parking prices $(P<0.01)$.

Overall the policies appear to have a positive correlation with each other.

\subsection{Conclusions}

The objective of this chapter and the surveys was to find out how Bandung citizens perceived their travel mode choices, and investigate their willingness to change their travel mode and to use public transport. The study analysed various factors of socio-economic and endogenous variables, such as attitude, personal capabilities, contextual factors and habit of respondents of the private vehicle users. The intention to use a particular mode of transport was, to a considerable degree, dependent on a vehicle's ownership. For instance, car and motorcycle owners have a positive correlation with the use of that which belongs to them. However, car users correlated more with this issue than did motorcycle owners. The frequency of using their owned transport mode had become habitual. This strongly determines the willingness to reduce their own private vehicles or increase their use of public transport. Psychological resistance did appear in this research that will hinder the reduction of private vehicles.

The use of online services, such as Grab and Go-JEK, as mode of transport mostly used involved more educated private vehicle owners, especially car-owners (see Table 7.3). This will undoubtedly help trigger saturated road capacity.

The preferences for the use of private and public vehicles involved the key considerations of speed, safety, and comfort. Secondary factors for using public transport were low-priced and difficulties to access and use private vehicles. People's knowledge and information and awareness regarding environmental impact, global environmental issues, and the use of public transport would not be the right indicators to help reduce the environmental impact of private cars. The frequency of private vehicle usage, as past behaviour, is an important aspect of habit. This influences goal-directed behaviour or, in this case, environmental significant behaviour by reducing private vehicle usage. It is also possible that cognitive dissonance to motivate drivers to reduce private vehicle usage were significant.

The majority of respondents were aware and responded positively regarding the climate change issue. They strongly agreed that climate change was a main problem to deal with. The respondents agreed that the transport sector was a source of climate change in urban areas and public transport was a tool to reduce this climate change. This was weakly significantly as a correlation.

${ }^{69}$ Based on the interviews with motorcycle users in this survey and interviews with the Local Transportation Department 
The result showed the tendencies to use private vehicles or public transport came when shorter travel time (auto-oriented respondents) were possible. If respondents needed to travel to several places the majority used private vehicles.

Respondent's attitude towards transport policy measures considered three policies. The strategy of push policies (see Chapter 3 ) as represented by (1) increasing taxes, (2) increasing parking prices, and (3) fuel increment. All respondents accepted fuel increments as an intervention to reduce the use of private vehicles. The respondents were familiar with the ups and downs of gasoline price because it has been referred to market mechanisms. The effect of raising gasoline price will influence poor people as it will reduce people's purchasing power for gasoline and other basic materials (Harefa, 2015). This condition will not affect respondents with vehicles in their family. As predicted, the majority of respondents are motorcycle users and these policies will be burdensome for vehicles users. However, the increase of fuel prices was deemed to not be a burden because private motorcycles were considered to be cheaper than paratransits or others public transportation.

The result shows that increased gasoline prices could encourage people to use public vehicles if several other terms had been applied (e.g. subsidies to public transport, basic materials and improvement to public transport facilities). This policy was expected to reduce gasoline consumption and create benefit for the national economy (by reducing the subsidies), to society, and the environment. 


\section{Chapter 8: Conclusions and Recommendation}

This thesis aimed to improve understanding on the role of climate change mitigation by theoretical and empirical research analysing dynamic actor interactions and the quality of governance in the transport sector governance.

The study has evaluated air quality improvements and the climate change mitigation programmes using the actor-based framework of the Contextual Interaction Theory (CIT). For this purpose, the concept of co-benefits' was introduced and applied to climate policy, which also deals with local activities. Co-benefits were defined as "the development and implementation of policies and strategies that simultaneously contribute to global change and tackle local environmental problems."

The governance and stakeholder characteristic of climate change mitigation were also analysed using the structural context part of the CIT framework (the use of Governance Assessment Tool). A survey of people's willingness to use other modes of transport and adopt new travel behaviour enriched the analysis of climate policy.

\subsection{Conclusion from the Empirical Chapters}

Chapter 1 assessed how to improve the current transport sector climate change mitigation policies in Bandung City to attain climate mitigation goals and support co-benefits. The main research question was - how do actor characteristics, interaction between actors and contextual factors influence the implementation of climate change mitigation in the transport sectors and contribute to selected co-benefits? And based on this - how can climate change mitigation policies in the transport sector be improved?

The first sub-research question was:

1. Which policies in Bandung City regarding the transport sector aim to contribute to lowering Greenhouse Gas (GHG) emissions and contribute to selected co-benefits?

The overall explanation for this research question was answered in Chapter 3. This question sought to find out how the implementation process of the GHG emissions reducing programmes in the transport sector in Bandung City could contribute to selected co-benefits. I used Contextual Interaction Theory here to points out the specific actor characteristics of motivations, cognitions, and capacity and power. I found that the local actors in Bandung City perceived policies to lower GHG emissions as a top-down approach from the national level that, nevertheless, has to be implemented at the provincial and local levels. However, the local government has the freedom to develop appropriate policies to reduce GHG emissions.

It is important to highlight that the policies to reduce GHG emission do not accord with what was specified by the government. The provincial and local governments were aware that the regulation stipulation delivered by the central government regarding mitigation on climate 
change stated both provincial and local level activity. However, most provincial and local level actors did not have any information about the implementation at their stage. This study established that these actors role in mitigation programmes were chosen according to their knowledge, resources, and power.

Several policies encouraged reduced GHG emissions were drive as a multi-actor interaction processes. Local actors and the provincial level in Bandung City proposed the Paratransit and CarFree Day to reduce GHG emission. Other programmes, such as TMB and vehicle test feasibility/emissions test, were also believed by the actors to reduce GHG emissions.

The co-benefits of these policies in Bandung City were to: (1) increase the fuel economy of vehicles; (2) reduce spending money and future operating costs; (3) unravel congestion; (4) improve health; (5) enhance local economic; and (6) attract tourism.

2. What qualities of the governance context and actor characteristics could have an impact on the effectiveness of the policies as established in answering question 1 in lowering of GHG emissions?

Chapter 4 studied the effectiveness of the implementation of policy instrument to lower GHG emissions elaborates further as to how policy instrument were perceived between implementers and target actors, as well as their interrelations with each other and in context. The structural context was researched considering the quality of governance for transport sector policy and climate change mitigation. The research also considered the wider context and its impact on the management of transportation in Indonesia.

Central government policy has influenced the use of private vehicles in Indonesia. Private vehicles contribute to the national economy through the development of automotive industries and taxes earned from society. Climate change mitigation in cities are influenced by private vehicles (motorcycle and cars) and efforts to reduce their use.

The quality of governance was researched from three programmes, namely: emission measurement, TMB, and paratransits. Two programmes (emission measurement and TMB) involved multiple levels and scales, while paratransits were managed at the local level. The governance context requires the TMB to improve their level of services.

The elements of governance considered three elements: (1) the actors and networks; (2) problem definitions and goals; and, (3) strategies and instruments. Many actors involved in public transport services make the competition between transport modes more difficult. There is a need for the implementing actors to reassess their goals and on how to improve the strategies to increase the level of services. Extended service time, dependable services (continuous), and separated lanes should become priorities for the actors.

The strategy to separate the niche roles from the TMB or DAMRI (other public buses) should be a solution to contribute to the sustainability of this mode of transportation. The paratransit is a restrictive programme that is contrary to aims of the Trans Metro Bandung. The paratransit has 
low qualities of governance. Help from the provincial and state level is needed to maintain the paratransits that do have the opportunity to play a role in reducing GHG emissions. The expanded growth of online business transport (Grab and GO-JEK) needs to be anticipated by improving the level of services, while waiting for new rules (laws) that regulates fair competition for the public transport sector.

The vehicle emission test programme is perceived as a common programme enacted by central government with an analysis result for quality of governance stated as low to moderate. This can be explained as follows. The current programmes do not extend far enough to create a strategy to actively maintain vehicles in good condition and, thus, benefit the environment. The programmes should be incorporating local problems into the climate change mitigation as they do the global problems.

The assessment result shows that, for all programmes that are intended to support the climate change mitigation as mentioned in the RAD-GRK, the extent to which they do so is classified as low to moderate; their flexibility as restrictive; and, their coherence and intensity as moderate. In general terms, these qualities create a context with some limits; although several improvements have shown positive trends at the local level.

The governance assessment of the climate change mitigation programmes perceived by the actors concluded that the problem perspectives and goals were faced by all cases. Different actor perspectives often complicated the development of the running programmes. For instance, the progress of public transport would sustain and improve continuously if the goals and perspectives of the actors were properly aligned. To understand and acknowledge other actor's problems would help solve the problems and eliminate resistance from other parties.

3. How can the specific context of the policies as a result of the answering question 2 be further improved in this case?

Chapter 5 addressed the multiplicity of actors dealing with public transport. Paratransit actors have warranted a special review as they provide a backbone and supply the feeder transport for Bandung City. They have decreased in number, and only 30\% are active. The governance assessment tool (GAT) was used to research the governance of paratransits.

The multilevel and scales of paratransit need further attention from the provincial level to regulate paratransit entering from other regions into Bandung. The strategy to separate this niche from the TMB or DAMRI should be a solution adding to the sustainability of paratransit transport. This strategy also should consider the expanded growth of online business transport (Grab and GO-JEK).

Many relevant actors are involved in managing local paratransit development. Local government appears to focus on the sustainability of other public transport. The plan to involve relevant stakeholders, such as cooperatives, to share the programmes with the local government has not yet been implemented; neither are the drivers to be empowered in the same way, as are bus drivers. It is difficult to use a local government budget to convert paratransit vehicles because 
this would have to handle a large number of paratransit vehicles. However, it is possible for the government to offer other actors, such as financial institutions, help to provide competitive financing facilities.

The poor management of paratransit has become a main problem and is reflected fin the burden faced by the drivers. They have to pay rent to owners and earn enough income to set aside for payments to vehicle owners, to pay for vehicle tests and terminal payments. Furthermore, these drivers are expected to provide an excellent service for passengers. The owners only have paid back their loan from leasing companies. However, these have higher interest rate than conventional bank loans. They also pay other expenses, such as the cost of vehicle maintenance and repair under severe conditions. The role of the drivers, as the front-line agents, was neglected by other actors, who (especially government) should be protecting and paying attention to driver's rights. The responsibilities of the cooperatives (who manage the paratransit vehicles and owners) or route-unit supervisor are limited to maintaining the routes, but these must be improved also by representing drivers and the paratransit owners.

Local government or paratransit actors (the cooperatives or KPU) have carried out numerous strategies and instruments. However, varying goals amongst public transportation actors lead to competition and conflicts. To improve services, paratransits need to change their system that has run already for more than a decade. Many strategies to improve the paratransit system have come to a halt. For instance, the plans to reduce the number of paratransit and convert them to bus transport have not proved workable. There is an opportunity to establish a common understanding of the problems related to the paratransit amongst all the actors involved and act in a coordinated way. In this way, the cause of the problem can be better understood and communicated amongst the local actors and amongst the regional and provincial level based on the need to manage the issues at scale.

All actors already have their respective responsibilities concerning their tasks at the case-specific level. However, there is a low degree of individual and institutional capacity to engage upperlevel actors or institutions in sharing responsibilities and roles to improve the transport systems. The role of every level must be recognised their multilayer form so problems that cannot be handled locally can be raised and solved at higher levels. Involving a broader scope of participants in multiple phases of the decision-making process, such as public participation, is one way of dealing with these sorts of problems.

The characteristics of actors in the interaction process show all actors have the motivation to manage and maintain paratransit sustainability. However, the use of paratransits, as a primary tool to mitigate climate change, was not information disseminated to the actors. The mitigation actions to lower GHG emissions was not particularly acknowledged by any of the actors; even though some programmes have already tried to reduce GHG emissions, such as rerouting and repooling as part of the management, traffic engineering, vehicle emission testing and gas-fuelling programme. External pressures, such as ride-sharing Grab and GO-JEK applications, have demotivated paratransit owners and drivers to maintain and keep better services. 
The information from implementing actors, such as local government, regarding public transport programmes and policies to lower GHG emissions have been shared with the cooperatives. However, the lack of updated information about the programmes has created conflict with other actors, especially drivers. The information sent generally came in one way through dissemination from the government and then forwarded by the cooperatives to the route-unit supervisors, representatives of paratransit owners and drivers.

The capacity and power of cooperatives and their experience in organising public transportation exists for paratransit and public bus transport. The capacity to cooperate with other stakeholders, such as the financial institutions, has been built over several years. The cooperatives have the capacity and power to collect fees from drivers. However, they do not have the capacity to organise and manage the drivers. The power is in the hand of the vehicle owners (paratransit) who select drivers and decide the daily instalment to collect. Local government has the power to regulate the vehicles based on their requirement. The drivers have become the weakest party in respect to capacity and power.

\section{How can the policies be further improved to contribute to selected co-benefits goals?}

Several criteria are needed to help attain co-benefits. These are the environmental, societal, and economic aspects adopted from the concept of sustainable development. The indicators of cobenefits divide into four aspects, such as: (1) sustainability of environmental related concerns (air pollution control, mitigation potential energy security); (2) development goals (improve access to public transport and reduce cost of transportation), (3) political and social feasibility; and (4) technical feasibility (evaluating system performance, data availability, quality; customer support and security).

The co-benefits approach is more relevant to public transport in the assessment of three policy instruments. This assessment assumed by the actual and current condition of the programmes, although further programmes should develop in the future. Experience from the study research shows only minor changes have occurred. The TMB bus rapid transit has met all its criteria of cobenefits and has the highest co-benefit impact. Paratransits have the positive value of the criteria of the climate change mitigation, energy and environmental sustainability, and development goals. The vehicle emission test met the criteria of sustainability and technical feasibility.

5. How relevant are actor's perspective concerning climate policies and their choice of travel mode?

The consideration of this research question was addressed in Chapter 7. The goal was to find out how the Bandung citizens perceived their choice of travel mode and assess their willingness to change to use public transport. The target group was private vehicle users (individual transport users) who also had the ability to use public transport. The survey sampled users offices, markets or malls, schools, universities, and residential areas. The sample size was 211 respondents with a response rate of $84 \%$. The availability of urban transport facilities at the respondent's location was a main consideration when choosing the sampling site. 
Three questions were addressed to obtain actor's perspective: first, to establish their knowledge and preference, specifically with respect to the local transport problem and a global issue of climate change; second, to compare user attitude on private vehicles and public transportation; and, finally questions regarding the low carbon transport programme as part of the climate change mitigation policy.

The three policy programmes encouraged the use of public transport. However, these have led to conflicting responses amongst actors (in this case with private vehicle users). The study found a correlation between factors, the socio-economic and endogenous variables, such as attitude, personal capabilities, contextual factors and habit of respondents of the private vehicle users. The intention to use a particular mode of transport is, to a considerable degree, dependent on the vehicle's ownership. For instance, car and motorcycle owners have a moderate positive correlation with the use of the items which belong to them (Spearman's Rho=.324; Sig. 0.000; $\mathrm{N}=210$ ). However, car users are more correlated with this issue than motorcycle owners. The historical frequency of transport mode use creates habits that then determined the willingness to reduce people's use of private vehicles or to allow them to increase the use of public transport. The policy to encourage the use of public transport will be hindered further by the existing condition of private vehicles. If there is no policy intervention to reduce private vehicles, the programme to raise the awareness of using public transport will experience many obstacles.

There were two factors to consider in using travel modes, namely: speed, safety, and comfort. Secondary issue affecting public transport use were low-priced fares and how difficult it was to use private vehicles. People's knowledge, information and awareness regarding environmental impact, global environmental issues, and the use of public transport would not be the right indicators to help reduce the environmental impact of private car use.

The results show the tendencies for people to use private vehicles, even when public transport offered shorter travel time (auto-oriented respondents). Also, if respondents needed to travel to several places, the majority used private vehicles. This confirms the intention to use private vehicles was more strongly related to a respondent's need to access multiple destinations.

The survey assessed respondent's preferences for mitigation climate change policies, as represented by increasing vehicle taxes, increasing parking prices, and fuel increments. These policies are the variables of travel behaviour. All respondents accepted fuel increments as an intervention to reduce the use of private vehicles. However, increased gasoline prices could encourage the use of public vehicles, if several additional terms were applied This policy would then reduce gasoline consumption and create a benefit to the national economy (by reducing the subsidies), to society, and benefit the environment. 


\subsection{Empirical Contributions and Policy Implications}

The empirical findings of the thesis can be useful to improve the policy and practice of the mitigation of climate change in the transport sector, particularly in Bandung City.

The national level dominates the multi-sectoral views of governance of the climate change mitigation in the transport sectors. The guidelines for mitigation action plan activities as stipulated by central government have to align with the provincial and local level needs and realities. The contribution to GHG emission reduction from lower-levels has to be measured and acknowledged as the mitigation action by and from the overall action of national views and activities. The empirical findings found that policies and programmes are top-down and the climate policy is not disseminated thoroughly for the transport sector, as is the case for every sector of climate mitigation.

Some climate policies that contribute to lowering GHG emissions are set at the central level, such as motor vehicle arrangement that include the low-cost green car (LCGC). These must be compatible with the public transport policies in urban areas, for example, in requiring vehicles to apply online and also serve paratransit vehicles.

The study found that the responsibilities and resources of governance in climate policy have to improve. The central government authorities need to regulate better the niche area among the transport modes, especially for public transport (among Trans Metro Bandung, Trans Bandung Raya, DAMRI (buses from central government) and Paratransit). The integration of all public transport will reduce the conflict and competing interests among and between the various transport modes.

The vehicle emission test stipulated at national level has to become a policy that attaches to the vehicle registration certificate at the provincial level. The central government can assist in developing the instruments and strategies to make the tests easy to access, effective in testing emissions and also ensure they go on to actively improve actual vehicle engine combustion for each vehicle.

The assessment of the policy intervention to lower GHG emissions for private vehicle users found that increasing the fuel cost has the highest contribution to make to reduce the use of private vehicles. However, the intervention also must consider the factors of speed of travel, safety, and comfort.

The empirical study found an absence of provincial authority in managing urban transport (particularly paratransit) in Bandung Basin. Local government has the power to regulate the vehicles based on their requirement and to regulate the drivers attached to paratransit owners. The drivers are the weakest party in the aspect of their capacity and power. Local level regulation for Bandung City was made weak as they did not apply equally to other paratransits from other regions who enter the city. 


\subsection{Reflections on the Theoretical Framework Used}

The findings of this thesis further develop the Contextual Interaction Theory (CIT) that was adopted as the main conceptual framework for the thesis. The contribution to the co-benefits approach used in the mitigation of climate change has been improved by adding the qualitative approach of CIT framework. Using the Governance Assessment Tool (GAT) enriched the climate policy research qualitative approach.

Climate change mitigation in the transport sector is a new empirical domain for CIT to be applied to. It mainly covered the multi-sector policies of energy, transportation, environment, land use, and economic development. Actor characteristics were researched further by introducing ideas from behaviour theory that targeted private vehicle users. The motive and cognitions of this group related to climate policy through their willingness to use alternative travel modes and, thereby, the results can help decision-makers respond to policy interventions. The introduction of environmental significant behaviour theory to the climate policy enriched the approach and helped achieve the research objective.

Another contribution was the use of GAT to research the co-benefits approach in the governance context. The analysis of the quality of governance elaborated many aspects of political, institutional, social and economic context to help enrich the criteria of co-benefits. The cobenefits approach helped inform the criteria and the technical aspects, as well as showing how this model can be applied and include governance context. The theoretical contributions and findings are also useful on a conceptual level to understand the political, institutional, and social challenges of climate change mitigation governance.

\subsection{Limitations and Suggestion for Future Research}

The main study limitation was its focus of analysis on just one case (Bandung City), which has its own unique characteristics. This has made it difficult to generalise the results of the study to other cities or jurisdictions. However, the results might still be widely applicable because the framework was set in a structural and a wider context. Part of the study looked at the efficacy of behaviour theory to support qualitative methods. The results were very positive. However, because only one actor group were analysed (i.e. private vehicles actors), future studies could extend the analysis to other user group and actors to enrich the results further.

This study drew on a set of governance theories and this was amplified with adding behaviour theory. There may well be other economic-based or management-based issue that have an impact on the policy processes and that have not been analysed in this study. The study results could re-analyse certain aspects further, for example, the criteria of co-benefits (Chapter 6 ) and the survey chapters (Chapter 7). Here, the analytical hierarchy process could be used to weight 
the criteria of co-benefits (Chapter 6). A multivariate analysis could be conducted by adding further case data for the methodology in Chapter 7.

Future research futures for this study could consider new contexts and new locations. Other potential programmes tackling climate change could be analysed further, especially for the application-based transportation that has developed widely across many cities. The theory framework or model could be expanded and tested further, especially for the values contained applying behaviour theory.

\subsection{Closing}

The outcomes to answering the research questions of this thesis primarily relate to a qualitative case study of climate change mitigation for the transport sector in Indonesia, with a particular local focus on Bandung City. The quantitative approach introduced Environmental Significant Behaviour Theory to enrich analysis of the characteristic of actors receiving and responding to policy interventions.

The theoretical and empirical conclusions have proved relevant to the understanding of other cases, where the climate policy enacted through both mitigation and adaptation actions occurs in and across all sectors. The framework used demonstrates that the findings are useful also in choosing the appropriate policy intervention or the best criteria to evaluate the co-benefits of climate change. 


\section{Bibliography}

Achmad, F. (2016). Re-routing belum menyeluruh (re-routing is not comprehensive). Retrieved February 8 , 2017, from http://bandungekspres.co.id/2016/re-routing-belum-menyeluruh/

ADB. (2006). Energy Efficiency and Climate Change Considerations for On-road Transport in Asia. Philippines.

ADB. (2008). Managing Asian Cities. Manila: Asian Development Bank (ADB).

Ajzen, I. (1991). The theory of planned behavior. Orgnizational Behavior and Human Decision Processes, 50, 179-211. https://doi.org/10.1016/0749-5978(91)90020-T

Ajzen, I. (2010). Constructing a theory of planned behavior questionnaire. Biofeedback and Selfregulation, 17, 1-7. https://doi.org/10.1016/0749-5978(91)90020-T

Andrieu, C., \& Pierre, G. Saint. (2014). Evaluation of ecodriving performances and teaching method: Comparing training and simple advice. European Journal of Transport and Infrastructure Research, 14(3), 201-213.

Angelidou, M. (2014). Smart city policies: A spatial approach. Cities, 41, S3-S11. https://doi.org/10.1016/j.cities.2014.06.007

Antique, \& Kurniawan, I. (2012). Alasan Program Konversi BBG tidak maksimal (The reason why the BBG conversion program is not optimal), p. 1 . Retrieved from http://www.viva.co.id/ramadan2016/read/292802-alasan-program-konversi-bbg-tak-laku

Arokiaraj, D., \& Banumathi, M. (2014). A Study on Eco - Driving Behaviour Of Passenger Car Users In Chennai. Research Journal of Social Science and Management, 03(11), 223-230.

Ashraf, M., Okamura, T., \& Nakamura, F. (2015). Public Satisfaction with Service Quality of Daewoo Urban Bus Service in Lahore, 11, 1097-1108.

Aviasti, Rukmana, A. N., \& Jamaludin. (2016). Model Penentuan Jumlah Armada Angkutan Kota yang Optimal di Kota Bandung (model determination of optimal city transportation fleet in Bandung City). Jurnal Penelitian Dan Pengabdian Masyarakat (Ethos), 42, 173-180.

Bache, I. (2010). Europeanization and multi-level governance: EU cohesion policy and pre-accession aid in Southeast Europe. Southeast European and Black Sea Studies, 10(1), 1-12. https://doi.org/10.1080/14683851003606739

Badan Kebijakan Fiskal. (2012). Desain Instrumen Transfer Fiskal untuk pendanaan Rencana Aksi Daerah Penurunan Emisi GRK (Design fiscal transfer instruments for funding regional action plans). Jakarta: BKF.

Bamberg, S., Fujii, S., Friman, M., \& Garling, T. (2011). Behaviour theory and soft transport policy measures. Transport Policy, 18(1), 228-235. https://doi.org/10.1016/j.tranpol.2010.08.006

Bamberg, S., \& Schmidt, P. (1999). Regulating Transport : Behavioural Changes in the Field. Journal of Consumer Policy, 22, 479-509. https://doi.org/10.1023/A:1006391723214

Bappeda. (2011). Review Masterplan dan Penyusunan Rancangan Peraturan Walikota Transportasi Kota Bandung. Bandung: Badan Perencanaan Pembangunan Daerah Kota Bandung.

Bappeda. (2013). Review Masterplan Transportasi kota Bandung. Bandung, Indonesia.

Bappenas. (2012). Laporan Satu Tahun Terbitnya RAN-GRK (A one-year report published action plans for GHG emissions) (Perpres 61 Tahun 2011). Indonesia.

Bappenas. (2013). National Action Plan for Climate Change Adaptation (RAN-API) Synthesis Report. Indonesia: Bappenas.

Barker, T. (2007). Climate Change 2007 : An Assessment of the Intergovernmental Panel on Climate Change. Change, 446(November), 12-17. https://doi.org/10.1256/004316502320517344

Beirão, G., \& Sarsfield Cabral, J. A. (2007). Understanding attitudes towards public transport and private car: A qualitative study. Transport Policy, 14(6), 478-489. https://doi.org/10.1016/j.tranpol.2007.04.009

Bigazzi, A. Y. (2011). Traffic Congestion Mitigation as an Emissions Reduction Strategy. Portland State University. 
Bizikova, L., Neale, T., \& Burton, I. (2008). Canadian Communities' Guidebook for Adaptation to Climate Change. Including an approach to generate mitigation co-benefits in the context of sustainable development. https://doi.org/ISBN: 978-1-100-10839-1

Bollen, Johannes. C; Brink, C.J.; Eerens, H.C.; Manders, A. J. G. (2009). Co-benefits of Climate Policy. International Energy Workshop 2009.

Bollen, J., Guay, B., \& Corfee-Morlot, J. (2009). Co-Benefits of Climate Change Mitigation Policies: Literature Review and New Results.

Bongardt, D., Creutzig, F., Huging, H., Sakamoto, K., Bakker, S., Gota, S., \& Bohler-Baedeker, S. (2013). Lowcarbon land transport: policy handbook. Gloucestershire: Routledge.

BPLH. (2013). Status Lingkungan Hidup Daerah Kota Bandung (Environmental Status Report). Bandung: Badan Pengelola Lingkungan Hidup Kota Bandung.

BPLH. (2014). Local action plan in addressing impact of climate change in Bandung city. Bandung.

BPLHD. (2015). Verification test to MRV of Regional Action Plan of GHG 2015. Bandung.

BPS Kota Bandung. (2013). Badan Pusat Statistik Kota Bandung. Retrieved January 21, 2015, from http://bandungkota.bps.go.id/subyek/penduduk-2013

BPS Kota Bandung. (2015). The Municipality of Bandung in Figures 2015. Bandung.

BPS Provinsi Jawa Barat. (2016). Jawa Barat Province in Figure 2016. Bandung, Indonesia.

Bratt, C., Stern, P. C., Matthies, E., \& Nenseth, V. (2014). Home, Car Use, and Vacation: The Structure of Environmentally Significant Individual Behavior. Environment and Behavior, 0013916514525038-. https://doi.org/10.1177/0013916514525038

Bressers, H. (2004). Implementing sustainable development: How to know what works, where, when and how. In W. M. Lafferty (Ed.), Governance for Sustainable Development: The Challenge of Adapting Form to Function (pp. 284-318). Cheltenham: Edward Elgar publishing.

Bressers, H. (2007). Contextual Interaction Theory and the issue of boundary definition: Governance and the motivation, cognitions and resources of actors. Governance An International Journal Of Policy And Administration, (January), 1-31.

Bressers, H. (2009). From Public Administration to Policy Networks: Contextual Interaction Analysis. In S. Narath \& F. Varone (Eds.), Rediscovering Public Law and Public Administration in Comparative Policy Analysis: a Tribute to Peter Knoepfel (pp. 123-141). Lausanne: Lausanne: Pressed poytechniques.

Bressers, H., Bressers, N., \& Larrue, C. (2016). Governance for Drought Resilience. (H. Bressers, N. Bressers, \& C. Larrue, Eds.). Springer.

Bressers, H., \& de Boer, C. (2013). Contextual interaction Theory for assessing water governance, policy and knowledge transfer. In Water Governance, Policy and Knowledge Transfer (pp. 36-54). Earthscan from Routledge.

Bressers, H., de Boer, C., Lordkipanidze, M., Özerol, G., Vinke-De Kruijf, J., Furusho, C., ... Browne, A. (2013). Water Governance Assessment Tools. Enschede: Drop Governance Team. Retrieved from www.dropproject.eu

Bressers, H., \& Kuks, S. (2003). What does "governance"mean? From conception to elaboration (Hans Bress, pp. 65-88). Westport, Connecticut.

Brogan, M. (2012). Suzuki APV: Road Test. Retrieved February 20, 2018, from https://www.motoring.com.au/suzuki-apv-road-test-28312/

Brophy, H. (2018). Grab Merges with Uber in Southeast Asia. Retrieved March 5, 2018, from https://www.grab.com/sg/press/business/grab-merges-with-uber-in-southeast-asia/

Bulkeley, H. (2003). Where the global meets the local? Sustainable cities and global environmental governance (pp. 16-18).

Bulkeley, H., \& Betsill, M. (2005). Rethinking Sustainable Cities: Multilevel Governance and the Urban Politics of Climate Change. Environmental Politics, 14(1), 42-63.

Bulkeley, H., \& Betsill, M. M. (2013). Revisiting the urban politics of climate change. Environmental Politics, 


\section{2(1), 136-154. https://doi.org/10.1080/09644016.2013.755797}

Bulkeley, H., Schroeder, H., Janda, K., Zhao, J., Armstrong, A., Chu, S. Y., \& Ghosh, S. (2009). Cities and Climate Change: The role of institutions, governance and urban planning. In Cities and Climate Change: Responding to an Urgent Agenda (pp. 125-159). Hemdon, VA, USA: World Bank.

Carruthers, R., Dick, M., \& Saurkar, A. (2005). Affordability of Public Transport in Developing Countries. Transport Papers.

Case, M., Ardiansyah, F., \& Spector, E. (2007). Climate Change in Indonesia: Implications for Humans and Nature. Energy. WWF.

Cash, D. W., Adger, W. N., Berkes, F., Garden, P., Lebel, L., Olsson, P., ... Young, O. (2006). Scale and CrossScale Dynamics: Governance and Information in a Multilevel World. Ecology and Society, 11(2), art8. https://doi.org/10.5751/ES-01759-110208

Casiano, C., \& de Boer, C. (2015). Symbolic implementation: Governance assessment of the water treatment plant policy in the Puebla's Alto Atoyac sub-basin. International Journal of Water Governance, 3(4), 124. https://doi.org/10.7564/14-IJWG79

Cervero, R. (1991). Paratransit in Southeast Asia: A Market Response to Poor Roads? Review of Urban \& Regional Development Studies, 3(1), 3-27. https://doi.org/10.1111/j.1467-940X.1991.tb00076.x

Cervero, R., \& Golub, A. (2007). Informal transport: A global perspective. Transport Policy, 14(6), 445-457. https://doi.org/10.1016/j.tranpol.2007.04.011

Chae, Y. (2010). Co-benefit analysis of an air quality management plan and greenhouse gas reduction strategies in the Seoul metropolitan area. Environmental Science and Policy, 13(3), 205-216. https://doi.org/10.1016/j.envsci.2010.01.003

Chapman, L. (2007). Transport and climate change: a review. Journal of Transport Geography, 354-367.

Clark, B., Lyons, G., \& Chatterjee, K. (2016). Understanding the process that gives rise to household car ownership level changes. Journal of Transport Geography, 55, 110-120. https://doi.org/10.1016/j.jtrangeo.2016.07.009

CLG. (2009). Multicriteria Analysis: a manual. London: Crown.

Collins, J., Thomas, G., Willis, R., \& Wilsdon, J. (2016). Carrots, sticks, and sermons : influencing public behaviour for environmental goals.

Creutzig, F., Mühlhoff, R., \& Römer, J. (2012). Decarbonizing urban transport in European cities: four cases show possibly high co-benefits. Environmental Research Letters, 7(4), 044042. https://doi.org/10.1088/1748-9326/7/4/044042

Dargay, J., \& Hanly, M. (2004). Land use and mobility. World Conference on Transport Research, (February), 1-16. Retrieved from http://discovery.ucl.ac.uk/1236/1/2004_14.pdf

Dawson, P. (2017). Assessment rubrics : towards clearer and more replicable design, research and practice. Assessment \& Evaluation in Higher Education, 42(3), 347-360. https://doi.org/10.1080/02602938.2015.1111294

de Boer, C., \& Bressers, H. (2013). Complex and Dynamic Implementation Processes. University of Twente and the Dutch Water Governance Centre (Vol. 53). University of Twente. https://doi.org/10.1017/СВ09781107415324.004

de Groot, J. I. M., \& Steg, L. (2007). Value Orientations to Explain Beliefs Related to Environmental Significant Behavior: How to Measure Egoistic, Altruistic, and Biospheric Value Orientations. Environment and Behavior, 40(3), 330-354. https://doi.org/10.1177/0013916506297831

De Nazelle, A., Nieuwenhuijsen, M. J., Anto, J. M., Brauer, M., Briggs, D., Braun-Fahrlander, C., ... Lebret, E. (2011). Improving health through policies that promote active travel: A review of evidence to support integrated health impact assessment. Environment International, 37(4), 766-777. https://doi.org/10.1016/j.envint.2011.02.003

de Winter, J., \& Dodou, D. (2010). Five-Point Likert Items : t Test Versus Mann - Five-Point Likert Items : t test versus Mann-Whitney-Wilcoxon. Practical Assessment, Research \& Evaluation, 15(October), 1-16. 
DeLeon, P., \& DeLeon, L. (2002). What Ever Happened to Policy Implementation? An Alternative Approach. Journal of Public Administration Research and Theory, 12(4), 467-492.

https://doi.org/10.1093/oxfordjournals.jpart.a003544

Deodhar, Vinay; Michaelowa, Axel; Krey, M. (2003). Financing Structures for CDM Projects in India and Capacity Building Options for EU-Indo Collaboration (No. 247). Hamburg. https://doi.org/10.2139/ssrn.452400

Department for Transport. (2004). The Future of Transport. A network for 2030. Crown Copyright. London. https://doi.org/10.1364/OFC.2015.Tu1A.1

Dessler, A. E. (2012). Introduction to modern climate change. Cambridge University Press.

detiknews. (2011, April 21). Uji Emisi 1.089 Kendaraan di Gedung Sate Pecahkan Rekor MURI. Retrieved from http://news.detik.com/berita-jawa-barat/1623074/uji-emisi-1089-kendaraan-di-gedung-satepecahkan-rekor-muri

Dinas Perhubungan. (2012). Studi Re-Pooling Angkutan Kota Bandung. Bandung.

Dinas Perhubungan. (2015). Bandung Transport Department Performance Report (LKIP). Bandung.

Dirgahayani, P. (2013). Environmental co-benefits of public transportation improvement initiative: the case of Trans-Jogja bus system in Yogyakarta, Indonesia. Cleaner Production, 58, 74-81.

Dirgahayuni, P. (2012). Policy Elements to Upscale the Contribution of Urban Transit Initiatives on Sustainable Urban Transport: The Case of Bus Improvement Initiatives in Indonesia.

Djellouli, N., \& Quevedo-Gómez, M. C. (2015). Challenges to successful implementation of HIV and AIDSrelated health policies in Cartagena, Colombia. Social Science and Medicine, 133(March 2015), 36-44. https://doi.org/10.1016/j.socscimed.2015.03.048

DNPI. (2010). Peluang dan Kebijakan Emisi: Sektor Transportasi (Opportunities and emission policy). Indonesia: Dewan Nasional Perubahan Iklim.

DPPW. (2004). Pedoman Konstruksi dan Bangunan (Guidelines of Building Construction).

Driejana. (2011). Study of Emission Reduction Potential for Clean Development Mechanism in Transportation Sector. Bandung.

Dubash, N. K., Raghunandan, D., Sant, G., Sreenivas, A., \& Dubash, Navroz K; Raghunandan, D; Sant, Girish; Sreenivas, A. (2013). Indian climate change policy: exploring co-benefits based approach. Economic and Political Weekly, XLVIII(22), 47-61.

Edwards, G. (1980). Implementing Public Policy. Washington DC: Congressional Quarterly Press.

EEA. (2011). Trends in share of household expenditure on transport ( percentage of total spending , EEA-32 ). Copenhagen. Retrieved from https://www.eea.europa.eu/downloads/17e8c48fa15d4e540d214b90dc726047/1354185636/term24trends-in-share-of-household-expenditure-on-transport-percentage-of-total-spending-eea.pdf

Egmond, C., Jonkers, R., \& Kok, G. (2006). One size fits all? Policy instruments should fit the segments of target groups. Energy Policy, 34(18), 3464-3474. https://doi.org/10.1016/j.enpol.2005.07.017

Egmond, C., R. Jonkers, \& Kok, G. (2006). Target group segmentation makes sense: If one sheep leaps over the ditch, all the rest will follow. Energy Policy, 34(17), 3115-3123. https://doi.org/10.1016/j.enpol.2005.06.002

Eilam, E., \& Trop, T. (2012). Environmental attitudes and environmental behavior-which is the horse and which is the cart? Sustainability, 4(9), 2210-2246. https://doi.org/10.3390/su4092210

Eldewisa, Z., \& Driejana. (2008). Perbandingan Estimasi Beban Emisi CO Dan $\mathrm{CO}_{2}$ Dengan Pendekatan Konsumsi Bahan Bakar Dan Kecepatan Kendaraan (Studi Kasus : Bunderan Cibiru-Lembang) the Comparison of $\mathrm{Co}$ and $\mathrm{CO}_{2}$ Emission Load Estimation With Fuel Consumption and Vehicles Speed Approach. Bandung.

Elmore, R. F. (1980). Backward mapping: Implementation research and policy decisions. Political Science Quarterly, 94(4), 601-616.

Eriksson, L. (2008). Pro-environmental travel behavior : and transport policy measures. 
Eriksson, L., Nordlund, A. M., \& Garvill, J. (2010). Expected car use reduction in response to structural travel demand management measures. Transportation Research Part F: Traffic Psychology and Behaviour, 13(5), 329-342. https://doi.org/10.1016/j.trf.2010.06.001

Farag, S., Dijst, M., \& Lanzendorf, M. (2003). Exploring the Use of E-Shopping and Its Impact on Personal Travel Behavior in the Netherlands. Transportation Research Record: Journal of the Transportation Research Board, 1858(November), 47-54. https://doi.org/10.3141/1858-07

Feng, Y., Fullerton, D., \& Gan, L. (2013). Vehicle choices, miles driven, and pollution policies. Journal of Regulatory Economics, 44(1), 4-29. https://doi.org/10.1007/s11149-013-9221-z

Ferreira, J. C., De Almeida, J., \& Da Silva, A. R. (2015). The Impact of Driving Styles on Fuel Consumption: A Data-Warehouse-and-Data-Mining-Based Discovery Process. IEEE Transactions on Intelligent Transportation Systems, 16(5), 2653-2662. https://doi.org/10.1109/TITS.2015.2414663

Friman, M., \& Linnér, B. (2015). Objectives for Nationally Appropriate Mitigation Actions ( NAMAs ): Moving from Mitigation to Sustainable Development for more Ambitious Climate Policy Moving from mitigation for a more ambitious climate agreement ? In Beyond 2015: Exploring the Future of Global Climate Governance (pp. 1-21).

Funazaki, A. (2012). Eco-driving - Introduction of the Japanese activities and a plan of demonstration in China. Japan.

Gana, J. A., \& Hoppe, T. (2017). Assessment of the governance system regarding adoption of energy efficient appliances by households in Nigeria. Energies, 10(1). https://doi.org/10.3390/en10010132

Gardner, G. T., \& Stern, P. C. (2002). Environmental problems and human behavior (2nd edition). Boston, MA: Pearson Custom Publishing.

Gärling, T., \& Schuitema, G. (2007). Private Car Use : Effectiveness, Public Acceptability and Political Feasibility. Journal of Social Issues, 63(1), 139-153.

Geels, F. W. (2011). The multi-level perspective on sustainability transitions: Responses to seven criticisms. Environmental Innovation and Societal Transitions, 1(1), 24-40. https://doi.org/10.1016/j.eist.2011.02.002

GIZ. (2004). Sustainable Urban Transport: Avoid-Shift-Improve (A-S-I). Retrieved from http://www.sutp.org/files/contents/documents/resources/E_Fact-Sheets-and-PolicyBriefs/SUTP_GIZ_FS_Avoid-Shift-Improve_EN.pdf

Goggin, M. L., Bowman, A. O. ., Lester, J. ., \& O’Toole, L. J. J. (1990). Implementation theory and practice: Toward a third generation. New York: HarperCollins Publishers.

Goldman, T., \& Gorham, R. (2006). Sustainable urban transport: Four innovative directions. Technology in Society 28, 261-273.

Golob, T. F., \& Hensher, D. A. (1998). Greenhouse gas emissions and australian commuters' attitudes and behavior concerning abatement policies and personal involvement. Transportation Research Part D: Transport and Environment, 3(1), 1-18. https://doi.org/10.1016/S1361-9209(97)00006-0

Gomm, R., Hammersley, M., \& Foster, P. (2000). Case Study Method. London: Sage Publications.

Greene, D.L; Wagener, M. (1997). Sustainable Transport. Journal of Transport Geography, 5(3), 177-190.

Greene, D.L; Wagener, M., Greene, D. L., \& Wegener, M. (1997). Sustainable Transport. Journal of Transport Geography, 5(3), 177-190. https://doi.org/10.1016/B978-1-85573-614-6.50016-1

Gudmundsson, H. (2001). Indicators and performance measures for Transportation, Environmental and Sustainability in North America. Natioanl Environmental Research Institute. Retrieved from http://www.dmu.dk/1_viden/2_publikationer/3_arbrapporter/rapporter/ar148.pdf

Guo, X. R., Cheng, S. Y., Chen, D. S., Zhou, Y., \& Wang, H. Y. (2010). Estimation of economic costs of particulate air pollution from road transport in China. Atmospheric Environment, 44, 3369-3377.

Gwilliam, K. (2002). Cities on the Move. The International Bank for Reconstruction and Development / The World Bank (Vol. 62). the World Bank. https://doi.org/10.2307/213227

Halimanjaya, A., \& Maulidia, M. (2014). The coordination of climate finance in Indonesia. Jakarta. 
Halsnaes, K., \& Shukla, P. (2008). Sustainable development as a framework for developing country participation in international climate change policies. Mitigation and Adaptation Strategies for Global Change, 13(2), 105-130. https://doi.org/10.1007/s11027-006-9079-9

Hamilton, K., \& Akbar, S. (2010). Assessing the Environmental Co-Benefits of Climate Change Actions. 2010 Enviroment Strategy, Analytical Background Papers, 1, 1-34.

Hanlon, S. (2000). Where do women feature in public transport ? Retrieved from https://www.fhwa.dot.gov/ohim/womens/chap34.pdf

Harefa, M. (2015). Kebijakan bbm bersubsidi dan rencana kenaikannya (Vol. VI). Jakarta, Indonesia. Retrieved from http://berkas.dpr.go.id/puslit/files/info_singkat/Info Singkat-VI-21-I-P3DI-November2014-5.pdf

Harker, J., Taylor, P., Knight-Lenihan, S., \& Knight-Lenihin, S. (2017). Multi-level governance and climate change mitigation in New Zealand: lost opportunities. Climate Policy, 17(4), 485-500. https://doi.org/10.1080/14693062.2015.1122567

Hertati, D., Supriyono, B., Zauhar, S., \& Wijaya, A. F. (2015). Restructuring the Regional Organization in Improving the Quality of Public Services in Government of Surabaya. International Journal of Applied Sociology, 5(1), 51-56. https://doi.org/10.5923/j.ijas.20150501.06

Hill, M., \& Hupe, P. (2002). Implementing Public Policy: Governance in Theory and in Practice. (I. Holliday, Ed.), Statewide Agricultural Land Use Baseline 2015 (Vol. 1). London: Sage Publications. https://doi.org/10.1017/СBO9781107415324.004

Hill, R. (1998). What Sample Size is " Enough " in Internet Survey Research ?, 6(3), 1-10.

Hiselius, L. W., Rosqvist, L. S., \& Adell, E. (2015). Travel behaviour of online shoppers in Sweden. Transport and Telecommunication, 16(1), 21-30. https://doi.org/10.1515/ttj-2015-0003

Hjern, B., \& Porter, D. O. (1981). Implementation Structures. A New Unit of Administrative Analysis. Organization Studies, 2, 211-227.

Hooghe, L., \& Marks, G. (2001). Type of Multi-level Governance. European Integration Online Papers, 5(December), 1-7.

Hooghe, L., \& Marks, G. (2004). European Integration and Democratic Competition. International Policy Analysis, 3, 1-8.

IBM Corp. (2010). IBM SPSS Statistics for Windows, Version 19. New York: Armonk.

IGES. (2011). Mainstreaming Transport Co - benefits Approach. A Guide to Evaluating Transport Projects.

Iles, R. (2005). Public Transport in Developing Countries. (R. Carruthers, M. Dick, \& S. Anuja, Eds.) (First Edit). UK: Elsevier Ltd. Retrieved from https://openknowledge.worldbank.org/handle/10986/17408

International Energy Agency. (2016). Energy and Air Pollution. World Energy Outlook - Special Report, 266. https://doi.org/10.1021/ac00256a010

IPCC. (2007). Climate Change 2007 Impacts, Adaptation and Vulnerability . Working Group II Assessment Report 4 IPCC.

Jack, D. W., \& Kinney, P. L. (2010). Health co-benefits of climate mitigation in urban areas. Journal of Environmental Sustainability, 2(3), 172-177. https://doi.org/10.1016/j.cosust.2010.06.007

Jaeger, A., Nugraha, S. B., Zusman, E., Nakano, R., \& Daggy, R. (2015). Governing sustainable low-carbon transport in Indonesia: An assessment of provincial transport plans. National Resources Forum, 39, 2740.

Jaeger, A., Nugroho, S. B., Zusman, E., Nakano, R., \& Daggy, R. (2014). Governing Sustainable Transport in Indonesia.

Jain, M., Hoppe, T., \& Bressers, H. (2017). A governance perspective on net zero energy building niche development in India: The case of New Delhi. Energies, 10(8). https://doi.org/10.3390/en10081144

Javid, M. A. (2017). Intentions of Car and Motorcycle Oriented Groups towards Public Transport In Lahore. Technical Journal, UET Taxila, Pakistan, 22(ii), 9-16.

Jeffrey L, A. P., \& Wildavsky. (1973). Implementation: How Great Expectations in Washington are Dashed in 
Oakland; or, Why It's Amazing that Federal Programs Work at All, This Being a Saga of the Economic Development Administration as Told by Two Sympathetic Observers Who Seek to Build Morals. University of California Press.

Jimmieson, N. L., Peach, M., \& White, K. M. (2008). Utilizing the Theory of Planned Behavior to Inform Change Management: An Investigation of Employee Intentions to Support Organizational Change. The Journal of Applied Behavioral Science, 44(2), 237-262. https://doi.org/10.1177/0021886307312773

Joewono, T. B., \& Kubota, H. (2005). The Characteristics of Paratransit and Non-motorized Transport in Bandung, Indonesia. Eastern Asia Society for Transportation Studies, 6, 262-277.

Joewono, T. B., \& Kubota, H. (2007). User Perceptions of Private Paratransit Operation in Indonesia. Journal of Public Transportation, 10(4), 99-118.

Joewono, T. B., \& Kubota, H. (2008). Paratransit service in Indonesia: User satisfaction and future choice. Transportation Planning and Technology, 31(3), 325-345. https://doi.org/10.1080/03081060802087692

Joewono, T. B., Tarigan, A. K. M., \& Susilo, Y. O. (2016). Road-based public transportation in urban areas of Indonesia: What policies do users expect to improve the service quality? Transport Policy, 49(July), 114-124. https://doi.org/10.1016/j.tranpol.2016.04.009

Jones, L. R. (2010). Restructuring Public Organizations in Response To Global Economic and Financial Stress. Public Management Review, 11(1), 1-14.

Kaklamanou, D., Jones, C. R., Webb, T. L., \& Walker, S. R. (2015). Using Public Transport Can Make Up for Flying Abroad on Holiday: Compensatory Green Beliefs and Environmentally Significant Behavior. Environment and Behavior, 47(2), 184-204. https://doi.org/10.1177/0013916513488784

Kamaluddin, R. (2000). Ekonomi Transportasi: Karakteristik, Teori dan Kebijakan. Jakarta: Ghalia Indonesia.

Kartika, U. (2015). Biar tidak ngetem hapus sistem setoran (Prohibited the instalment system to reduce halted paratransit). Retrieved February 8, 2017, from http://tekno.kompas.com/read/2015/01/06/11062691/Biar.Tidak.Ngetem.Hapus.Sistem.Setoran.Angk ot

Kementerian Lingkungan Hidup. (2012). Pedoman penyelenggaraan inventarisasi gas rumah kaca nasional. Pedoman penyelenggaraan inventarisasi gas rumah kaca nasional. Jakarta, Indonesia. Retrieved from https://www.google.co.id/url?sa=t\&rct=j\&q=\&esrc=s\&source=web\&cd=1\&cad=rja\&uact=8\&ved=0ahU KEwilnYmHp4LQAhWFpY8KHUzQBY4QFggfMAA\&url=http://www.kemenperin.go.id/download/11221\& usg=AFQjCNH_FvQz7x1j9DhfxepLnzSERTxKwg\&bvm=bv.136811127,d.c2l

Khademi, E., Timmermans, H., \& Borgers, A. (2014). Temporal adaptation to reward schemes: Results of the spitsscoren project. Transportation Research Procedia, 3(July), 60-69. https://doi.org/10.1016/j.trpro.2014.10.091

Koizumi, Y., Nishimiya, N., \& Kaneko, M. (2013). Urban Transportation Characteristics and Urban Mass Transit Introduction in the Cities of Developing Countries. Journal of the Eastern Asia Society Fo Transportation Studies, 10(1999), 81-99.

Kollmuss, A., \& Agyeman, J. (2002). Mind the Gap: why do people act environmentally and what are the barriers to pro-environmental behavior? Environmental Education Research, 8(3), 239-260. https://doi.org/10.1080/1350462022014540

KPPU. (2009). Analisis Kebijakan Persaingan dalam Industri Angkutan Darat Indonesia (analysis of competition policy). Jakarta, Indonesia.

Kurniawan, R. (2016). Dishub Kota Bandung Bentuk Tim Khusus untuk Bersihkan Angkot llegal (Build task force to reduce illegal paratransit). Retrieved February 13, 2017, from http://jabar.metrotvnews.com/read/2016/03/21/501399/dishub-kota-bandung-bentuk-tim-khususuntuk-bersihkan-a

Kuwahara, M., de Kievit, M., Shladover, S., Zhang, W.-B., \& Barth, M. (2013). Guidelines for Assessing the Effects of ITS on $\mathrm{CO}_{2}$ Emissions - International Joint Report -.

Lasco, R. D., \& Boer, R. (2006). An Integrated Assessment of Climate Change Impacts, Adaptations and 
Vulnerability in Watershed Areas and Communities in Southeast Asia (Vol. 2003). Washington, DC USA: The International START Secretariat.

Lazuardi, I. T. (2016). Protes Bus Sekolah Gratis, Supir Angkutan di Bandung Mogok (Free school buses, mass streak of paratransit). Retrieved from https://m.tempo.co/read/news/2016/06/02/058776313/protesbus-sekolah-gratis-sopir-angkutan-di-bandung-mogok

Lee, T., \& Van De Meene, S. (2013). Comparative studies of urban climate co-benefits in Asian cities: An analysis of relationships between $\mathrm{CO}_{2}$ emissions and environmental indicators. Journal of Cleaner Production, 58, 15-24. https://doi.org/10.1016/j.jclepro.2013.04.047

Li, G., Nugroho, S. B., Fujiwara, A., Zhang, J., \& Linh, T. N. (2011). Analysis of Paratransit Drivers ' Stated Job Choice Behavior under Various Policy Interventions Incorporating the Influence of Captivity : A Case Study in Jabodetabek Metropolitan Area , Indonesia. Eastern Asia Society for Transportation Studies, 8, $1-5$.

Lipsky, M. (1980). Street-level democracy: dilemmas of the individual in public services (2010 ${ }^{\text {th }}$ ed.). New York: Russel Sage Foundation.

Liputan 6. (2008, December 22). Sopir Angkutan Protes Transmetro Bandung. Retrieved from http://news.liputan6.com/read/170216/sopir-angkutan-protes-transmetro-bandung

Liu, X., \& Bohlin, L. (2013). Effects from consistent internalization of external effects from transport and manufacturing - a CGE analysis for Sweden. Retrieved from http://www.oru.se/pagefiles/13614

Mailbach, M., Schreyer, C., Sutter, D., van Essen, H. P., Boon, B. H., Smokers, R., ... Bak, M. (2008). Handbook on estimation of external costs in the transport sector. Delft CE.

Matland, R. (1995). Synthesising the implementation literature: the ambiguity- conflict model of policy implementation. Journal of Public Administration Research and Theory, 5(2), 145-174.

Mauludi, R. (2016). Harus berbadan hukum, pemilik angkot perlu panduan (must be a legal entity, paratransit owners need guidance). Retrieved February 7, 2017, from http://www.inilahkoran.com/berita/bogor/61413/harus-berbadan-hukum-pemilik-angkot-perlupanduan

Mcgrath, J., Hine, J., \& Gunay, B. (2007). The mobility of low income households in the Greater Belfast Area. In Social Research. Institute of Transport Studies (Monash).

Mdivani, K., \& Hoppe, T. (2016). Experience with LEDS and NAMA low carbon strategies: The case of Georgia. Sustainability (Switzerland), 8(6), 1-22. https://doi.org/10.3390/su8060535

Milward, H. B., \& Provan, K. G. (2000). Governing the Hollow State. Journal of Public Administration Research and Theory, 10(2), 359-379. https://doi.org/10.1093/oxfordjournals.jpart.a024273

Ministry of Environment Japan. (2012). The Co-benefits Approach for GHG Emission Reduction Projects, (Cdm), 1-8.

Ministry of the Environment Government of Japan. (2009). Manual for Quantitative Evaluation of the CoBenefits Approach to Climate Change Projects. Retrieved from http://www.env.go.jp/en/earth/cc/manual_qecba.pdf

MoE. (2007). Indonesia country report: Climate Variability and Climate Change and their Implication. (R. S. Boer, Ed.). Jakarta: Ministry of Environment Republik of Indonesia.

Moglia, M., \& Marquez, L. (2002). Assessing Benefits \& Costs of Vehicle Emissions Testing in Australia. In 24th Conference of Australian Institutes of Transport Research (pp. 1-14).

Mohlakoana, N. (2014). Implementing the South African Free Basic Alternative Energy Policy. University of Twente.

Monzon, A., \& Guerrero, M.-J. (2004). Valuation of social and health effects of transport-related air pollution in Madrid (Spain). Science of the Total Environment, 334-335, 427-434.

Mulia, P. (2013). Angkot Gratis Bandung Telan Biaya Rp. 100 Juta, p. 2.

Munoz-Restrepo, A. (2017). Rethinking the Uses of Assessment in the Second Language Classroom. Revista Internacional de Investigation En Educacion, 9(19), 115-132. https://doi.org/10.11144/Javeriana.m9- 
19.ruas

Muttaqien, S. (2011). Angkot diganti bus, pengusaha bentuk konsorsium. Retrieved February 8, 2017, from http://m.inilah.com/news/detail/1276662/angkot-diganti-bus-pengusaha-bentuk-konsorsium

Myers, N. D., Ahn, S., \& Jin, Y. (2011). Sample size and power estimates for a confirmatory factor analytic modelin exercise and sport: a Monte Carlo approach. Research Quarterly for Exercise and Sport, 82(3), 412-423. https://doi.org/https://doi.org/10.1080/02701367.2011.10599773

Nemet, G. F., Holloway, T., \& Meier, P. (2010). Implications of incorporating air-quality co-benefits into climate change policymaking. Environmental Research Letters, 5(1), 014007. https://doi.org/10.1088/1748-9326/5/1/014007

Nugroho, S. B. (2016). Co-benefits Action Plan for Bandung. Bandung.

Nugroho, S. B., \& Zusman, E. (2015). Governing Public Transport Improvement Program in Indonesia. Journal of the Eastern Asia Society Fo Transportation Studies, 1-15.

O'Toole, L. J. (1986). Policy recommendations for multi-actor implementation: An assessment of the field. Journal of Public Policy, 6(2), 181-210.

O’Toole, L. J. J. (1995). Rational choice and policy implementation. American Review of Public Administration, 25(1), 43-57.

OECD. (1997). Towards Sustainable Transportation. In The Vancouver Conference (pp. 1-183). Canada: OECD.

OECD. (2002). Strategies to reduce greenhouse gas emissions from road transport: Analytical methods. France. Retrieved from http://www.internationaltransportforum.org/Pub/pdf/02GreenhouseE.pdf

Olsen, K. H., Bizikova, L., Harris, M., Boodoo, Z., Gagnon-Lebrun, F., \& Bakhtiari, F. (2015). Framework for measuring sustainable development in NAMAs. https://doi.org/10.13140/RG.2.1.2053.7848

Osborne, J. W., \& Costello, A. B. (2005). Best Practices in Exploratory Factor Analysis: Four Recommendations for Getting the Most From Your Analysis. Practical Assessment, Research \& Evaluation, 10(7), 1-9. Retrieved from https://pareonline.net/pdf/v10n7a.pdf

Ostrom, E., Janssen, M., \& Anderies, J. M. (2007). Going Beyond Panaceas. In National Academy of Sciences 104 (39) (pp. 15176-15178). https://doi.org/DOI10.1073/pnas.0701886104

Owens, K. A. (2008). Understanding How Actors Influence Policy Implementation: A comparative study of wetland restorations in New Jersey, Oregon, The Netherlands and Finland.

Owens, K. A., \& Bressers, H. (2013). A Comparative Analysis of How Actors Implement: Testing the Contextual Interaction Theory in 48 Cases of Wetland Restoration. Journal of Comparative Policy Analysis: Research and Practice, 15(3), 203-219. https://doi.org/10.1080/13876988.2013.785668

Pardo, C. F. (2010). Sustainable Urban Transport. Shanghai Manual: A Guide for Sustainable Urban Development in the 21st Century, 38. https://doi.org/10.3141/2243-05

Pavlovskaia, E. (2014). Sustainability criteria : their indicators, control , and monitoring ( with examples from the biofuel sector ), 1-12. https://doi.org/10.1186/s12302-014-0017-2

Peden, M. M., Krug, E., \& Mohan, D. (2001). Five-year WHO Strategy on Road Traffic Injury Prevention. Geneva.

Pemprov Jawa Barat. (2013). Konsep awal pengembangan Metropolitan Bandung Raya. Jawa Barat.

Perambahan, A. (2009). Bemo, Dulu Menggemaskan Sekarang Mengenaskan. Retrieved February 2, 2017, from http://www.asal-usul.com/2009/06/sejarah-bemo.html

Permadi, D. A., Kim Oanh, N. T., \& Vautard, R. (2017). Assessment of co-benefits of black carbon emission reduction measures in Southeast Asia: Part 2 emission scenarios for 2030 and co-benefits on mitigation of air pollution and climate forcing. Atmospheric Chemistry and Physics Discussions, (May), 1-21. https://doi.org/10.5194/acp-2017-316

Peters, G., \& Pierre, J. (2006). Handbook of Public Policy. London: Sage Publications.

Phun, V. K., Lim, I., \& Yai, T. (2015). The Characteristics of Paratransit Operation and Fare in Phnom Penh. Journal of the Eastern Asia Society for Transportation Studies, 11, pp 1307--1327. Retrieved from 
http://dx.doi.org/10.11175/easts.11.1307\%5Cn

Pongthanaisawan, J., \& Sorapipatana, C. (2010). Relationship between level of economic development and motorcycle and car ownerships and their impacts on fuel consumption and greenhouse gas emission in Thailand. Renewable and Sustainable Energy Reviews, 14(9), 2966-2975.

https://doi.org/10.1016/j.rser.2010.07.034

Pratiwi, P. (2015). Bureaucratic Reform in Indonesia : Innovation, Challenges and Typologies. In International Institute of Administrative Science - AGPA (pp. 1-17).

PRFM. (2015). Penghapusan sistem setoran angkot sulit diterapkan di Bandung. Retrieved February 8, 2017, from https://id-id.facebook.com/PRFMNewsChannel/posts/598113936986872

Puppim De Oliveira, J. A. (2013). Learning how to align climate, environmental and development objectives in cities: Lessons from the implementation of climate co-benefits initiatives in urban Asia. Journal of Cleaner Production, 58, 7-14. https://doi.org/10.1016/j.jclepro.2013.08.009

Puppim De Oliveira, J. A., Doll, C. N. H., Kurniawan, T. A., Geng, Y., Kapshe, M., Huisingh, D., ... Huisingh, D. (2013). Promoting win-win situations in climate change mitigation, local environmental quality and development in Asian cities through co-benefits. Cleaner Production, 58, 1-6. https://doi.org/10.1016/j.jclepro.2013.08.011

Purnama, R. (2017). Angkot di Depok harus berbadan hukum, sampai 30 Juni. Retrieved February 7, 2017, from https://metro.sindonews.com/read/1174187/170/angkot-di-depok-harus-berbadan-hukumdeadline-sampai-30-juni-1485347648

Putri, W. D. (2016). Kurangi volume kendaraan, angkot di Bandung akan di konversi ke bus. Retrieved from http://www.msn.com/id-id/berita/other/kurangi-volume-kendaraan-angkot-di-bandung-akandikonversi-ke-bus/ar-BBqtsfK

Rabl, A., \& de Nazelle, A. (2012). Benefits of shift from car to active transport. Transport Policy, 19, 121131.

Rachmandy, A. (2013). Program Angkot Day di Kota Bandung Tidak Jelas, p. 1. Retrieved from http://www.bandungnewsphoto.com/2013-10-13/program-angkot-day-di-kota-bandung-tidak-adakejelasan

Radar Bangka. (2015, October 15). 2016, Plat kuning harus berbadan hukum. Retrieved February 7, 2017, from http://www.radarbangka.co.id/berita/detail/belitong/34655/2016-plat-kuning-harus-berbadanhukum.html

Rahman, M. M., Paatero, J. V., Lahdelma, R., \& Wahid, M. A. (2016). Multicriteria-based decision aiding technique for assessing energy policy elements-demonstration to a case in Bangladesh. Applied Energy, 164, 237-244. https://doi.org/10.1016/j.apenergy.2015.11.091

Redman, L., Friman, M., Gärling, T., \& Hartig, T. (2013). Quality attributes of public transport that attract car users: A research review. Transport Policy, 25, 119-127. https://doi.org/10.1016/j.tranpol.2012.11.005

Republika. (2009). Angkot usia diatas 15 tahun dilarang beroperasi. Retrieved from http://www.republika.co.id/berita/shortlink/94284

Rhodes, R. a W. (1996). The new governance: Governing without government. Political Studies, 44(4), 652667. https://doi.org/10.1111/j.1467-9248.1996.tb01747.x

Robert, J. T. (2007). A climate of injustice: global inequality, North-South Politics, and climate policy. Massachusetts Institute of Technology.

Rosadi, D. (2016). Hemat dan ramah lingkungan angkutan umum di kota Bandung akan konversi. Retrieved from http://bandung.merdeka.com/halo-bandung/hemat-dan-ramah-lingkungan-angkutan-umum-dikota-bandung-akan-konversi-160617c.html

Rothstein, B. (1998). Just Institutions Matter: The Moral and Political Logic of the Universal Welfare State. Cambridge: Cambridge University Press.

Sabatier, P. A., \& Mazmanian, D. A. (1980). The Implementation of Public Policy: A Framework of Analysis. Policy Studies Journal, 8(Special Issue), 538-560.

Samantha, G. (2013). national geographic. Retrieved from 
http://nationalgegraphic.co.id/berita/2013/09/cara-terbaik-tekan-emisi-angkutan-umum

Sangho Choo, U., Mokhtarian, P. L., \& Salomon Leon, I. J. (2002). Does Telecommuting Reduce Vehicle-Miles Traveled? an Aggregate Time Series Analysis for the. Transportation, 37-64.

Scarpellini, S., Valero, A., Llera, E., \& Aranda, A. (2013). Multicriteria analysis for the assessment of energy innovations in the transport sector. Energy, 57, 160-168.

Scharpf, F. . (1978). Interorganizational policy studies: Issues, concepts and perspectives. London: Sage Publications.

Scheiner, J., \& Holz-Rau, C. (2007). Travel mode choice: Affected by objective or subjective determinants? Transportation, 34(4), 487-511. https://doi.org/10.1007/s11116-007-9112-1

Schiller, P. L., Brunn, E. C., Kenworthy, J. R., Bruun, E. C., \& Kenworthy, J. R. (2010). An introduction to sustainable transportation policy, planning and implementation. UK: Earthscan Ltd.

Schneider, R. J. (2013). Theory of routine mode choice decisions: An operational framework to increase sustainable transportation. Transport Policy, 25, 128-137. https://doi.org/10.1016/j.tranpol.2012.10.007

Schwanitz, V. J., Longden, T., Knopf, B., \& Capros, P. (2015). The implications of initiating immediate climate change mitigation - A potential for co-benefits? Technological Forecasting and Social Change, 90(PA), 166-177. https://doi.org/10.1016/j.techfore.2014.01.003

Sener, I. N., \& Reeder, P. R. (2014). An integrated analysis of workers' physically active activity and active travel choice behavior. Transportation Research Part A: Policy and Practice, 67, 381-393. https://doi.org/10.1016/j.tra.2014.03.007

Setiawan, W., Arwin, S., \& Maria, P. N. A. (2006). Permasalahan dan Strategi Pembangunan Lingkungan Berkelanjutan Studi Kasus : Cekungan Bandung. Indonesian Journal on Geoscience, 1(3), 163-171. Retrieved from http://ijog.bgl.esdm.go.id

Shaheen, S., Cohen, A., Zohdy, I., \& Kock, B. (2016). Smartphone Applications to Influence Travel Choices: Practices and Policies.

Shrestha, R. M., \& Pradhan, S. (2010). Co-benefits of $\mathrm{CO}_{2}$ emission reduction in a developing country. Energy Policy, 38(5), 2586-2597. https://doi.org/10.1016/j.enpol.2010.01.003

Stake, R. E. (1995). The art of case study research. Thousand Oaks, California: Sage Publications.

Steele, K., Carmel, Y., Cross, J., \& Wilcox, C. (2009). Uses and Misuses of Multicriteria Decision Analysis (MCDA) in Environmental Decision Making. Risk Analysis, 29, 1-8.

Steg, L., \& Vlek, C. (2009). Encouraging pro-environmental behaviour: An integrative review and research agenda. Journal of Environmental Psychology, 29(3), 309-317. https://doi.org/10.1016/j.jenvp.2008.10.004

Stern. (2006). The Economic of Climate Change. http://www.hm-treasury.gov.uk/stern_review_report.htm.

Stern, P. C. (2000). Toward a Coherent Theory of Environmentally Significant Behavior. Journal of Social Issues, 56(3), 407-424. https://doi.org/10.1111/0022-4537.00175

Stern, P. C. (2011). Contributions of psychology to limiting climate change. The American Psychologist, 66(4), 303-314. https://doi.org/10.1037/a0023235

Stern, P. C., Dietz, T., Abel, T., Guagnano, G. A., \& Kalof, L. (1999). A value-belief-norm theory of support for social movements: The case of environmentalism. Human Ecology Review, 6(2), 81-97. https://doi.org/10.2307/2083693

Sturgis, P., Robert, C., \& Smith, P. (2014). Middle alternatives revisited: How the neither/nor response acts as a way of saying 'I don't know'. Sociological Methods \& Research, 43(1), 15-38.

Sumarsono, P. (2014). “Kontrak Pelayanan Angkutan Umum Perkotaan” Sebuah Kebijakan Publik untuk Meningkatkan Kualitas Pelayanan. Bappenas, (September), 87-99.

Susanti, V., Hartanto, A., Ridwan, A. S., Hendri, M. S., Estiko, R., \& Hapid, A. (2010). Pengurangan Subsidi BBM dan Polusi Udara melalui Kebijakan Program Konversi dari BBM ke BBG untuk Kendaraan di Provinsi Jawa Barat. Journal of Mechatronic, Electrical Power, and Vehicular Technology, 01(2), 43-52. 
Sutandi, A. C., \& Pinem, R. D. A. (2017). The Application of Road Lighting Standard Towards Sustainable Transportation in Large Cities in Indonesia. Procedia Engineering, 171, 1463-1471.

https://doi.org/10.1016/j.proeng.2017.01.471

Sutrisno, O. D. (2017). Jumlah Angkot di Bandung yang Beroperasi Tinggal 30 Persen. Retrieved July 5, 2018, from http://jabar.metrotvnews.com/peristiwa/zNA7026k-jumlah-angkot-di-bandung-yang-beroperasitinggal-30-persen

Suzuki, T., \& Muromachi, Y. (2005). Population Density - Automobile Use Relationship: Re-Examination In Asian and American Mega-cities. Journal of the Eastern Asia Society for Transportation Studies, 6, 3954.

Syabri, I., Pradono, \& Soegijanto, B. T. (2013). Embracing Paratransit in Bandung Metropolitan Area, West Java , Indonesia. Retrieved from http://www.unhabitat.org/grhs/2013

Syaifudin, T. M. G. (2016). 20 Mobil Angkot Omprengan di Kota Bandung Diamankan Polisi. Retrieved February 12, 2017, from http://www.tribunnews.com/regional/2016/05/11/20-mobil-angkotomprengan-di-kota-bandung-diamankan-polisi

Tamin, O. Z. (2005). Integrated Public and Road Transport Network System for Bandung Metropolitan Area (Indonesia). Journal Eastern Asia Society for Transportation Studies, 5, 1128-1135.

Tarigan, A. K. M., Susilo, Y. O., \& Joewono, T. B. (2014). Segmentation of paratransit users based on service quality and travel behaviour in Bandung, Indonesia. Transportation Planning and Technology, 37(2), 200-218.

Tempo. (2016). nasional.tempo.co. Retrieved from http://nasional.tempo.co/read/news/2016/01/12/058735177/ridwan-kamil-pecat-kepala-dinasperhubungan-bandung

Tertoolen, G., Kreveld, D. I. K. V. A. N., \& Verstraten, B. E. N. (1998). Psychological Resistance Against Attempts to Reduce Private Car Use. Transportation Research Part A: Policy and Practice, 32(3), 171181.

Teubner, T. (2015). Thoughts on the Sharing Economy. In ICT, Society and Human Beings 2014 (pp. 322326).

Thambiran, T., \& Diab, R. D. (2011). Air pollution and climate change co-benefit opportunities in the road transportation sector in Durban, South Africa. Atmospheric Environment, 45(16), 2683-2689. https://doi.org/10.1016/j.atmosenv.2011.02.059

Tiglao, N. C. C. (2007). Integrating Environmentally Sustainable Transport and Metropolitan Development Under a Decentralized Framework, 6.

Tilburg, V. X., Würtenberger, L., Coninck, D. H., \& Bakker, S. (2011). Paving the way for low-carbon development strategies. the Netherlands: ECN. Retrieved from http://www.ecn.nl/docs/library/report/2011/e11059.pdf

TRB. (2001). Transportation, Energy, and Environmental Policy : Managing Transitions. Washington DC: TRB.

Tri Basuki Joewono, \& Hisashi Kubota. (2007). Exploring Public Perception of Paratransit Service Using Binomial Logistic Regression. Civil Engineering Dimension, 9(1), pp.1-8. Retrieved from http://puslit2.petra.ac.id/ejournal/index.php/civ/article/view/16583

Tursilowati. (2004). Urban Heat Island dan Kontribusinya pada Perubahan Iklim dan Hubungannya dengan Perubahan Lahan. Pusat Pemanfaatan Sains Atmosfer Dan Iklim LAPAN, 1-8.

Tursilowati, L. (2002). Urban Heat Island dan Kontribusinya pada Perubahan Iklim dan Hubungannya dengan Perubahan Lahan. In Pemanasan Global dan Perubahan Global - Fakta, Mitigasi, dan Adaptasi (pp. 8996).

Tyler, E., Boyd, A., Coetzee, K., Torres Gunfaus, M., \& Winkler, H. (2013). Developing country perspectives on "mitigation actions", "NAMAs", and "LCDS." Climate Policy, 13(6), 770-776. https://doi.org/10.1080/14693062.2013.823334

UNFCCC. (1998). Kyoto Protocol to The United Nations Framework Convention on Climate Change. Retrieved from http://unfccc.int/resource/docs/convkp/kpeng.pdf 
UNFCCC. (2007). Climate Change: Impacts, Vulnerabilities and Adaptation in Developing Countries. United Nations Framework Convention on Climate Change. Bonn, Germany: United National Framework Convention on Climate Change. Retrieved from http://unfccc.int/resource/docs/publications/impacts.pdf

UNFCCC. (2014). Handbook on Measurement, Reporting and Verification.

United Nations. (2007). Public Governance Indicators : A Literature Review. Retrieved from https://publicadministration.un.org/publications/content/PDFs/E-Library Archives/2007 Public Governance Indicators_a Literature Review.pdf

Ürge-Vorsatz, D., Herrero, S. T., Dubash, N. K., \& Lecocq, F. (2014). Measuring the Co-Benefits of Climate Change Mitigation. Annual Review of Environment and Resources, 39(1), 549-582. https://doi.org/10.1146/annurev-environ-031312-125456

Utomo, D. (2017, February 2). Bemo, Meski Sudah Udzur Tetap Beroperasi di Jakarta (Metropolitan), p. 1. Retrieved from www.pelita.or.id/baca.php?id=34038

Utomo, Y. W. (2015). Emisi karbon dari sektor energi yang terus meningkat. National Geographic Indonesia.

Van, H. T., Choocharukul, K., \& Fujii, S. (2014). The effect of attitudes toward cars and public transportation on behavioral intention in commuting mode choice-A comparison across six Asian countries. Transportation Research Part A: Policy and Practice, 69, 36-44. https://doi.org/10.1016/j.tra.2014.08.008

Van Meter, D. S., \& Van Horn, C. E. (1975). The Policy Implementation Process: A Conceptual Framework. Administration \& Society, 6(4), 445-488. https://doi.org/10.1177/009539977500600404

van Vuuren, D. P., Cofala, J., Eerens, H. E., Oostenrijk, R., Heyes, C., Klimont, Z., ... Amann, M. (2006). Exploring the ancillary benefits of the Kyoto Protocol for air pollution in Europe. Energy Policy, 34(4), 444-460. https://doi.org/10.1016/j.enpol.2004.06.012

Verma, A., \& Ramanayya, T. (2014). Public transport planning and management in developing countries. Retrieved from https://www.google.com/books?hl=ru\&lr=\&id=XliZBQAAQBAJ\&oi=fnd\&pg=PP1\&dq=Public+Transport+ Planning+and+Management+in+Developing+Countries\&ots=ekJyxI7pM\&sig=y_loU3sRMNgjYPec_hjERMPWQKs

Wallsten, S. (2015). The Competitive Effects of the Sharing Economy : How is Uber Changing Taxis ? Technological Policy Institute, (June), 1-22. Retrieved from www.researchgate.net/publication/279514652_The_Competitive_Effects_of_the_Sharing_Econo

Watson, R. T., Albritton, D. L., Barker, T., Bashmakov, I. a., Canziani, O., Christ, R., \& Cubasch, U. (2001). Climate Change 2001: Synthesis Report. Assessment (Vol. 1). Retrieved from http://www.grida.no/publications/other/ipcc_tar/?src=/CLIMATE/IPCC_TAR/vol4/english/index.htm

West, J. J., Smith, S. J., Silva, R. A., Naik, V., Zhang, Y., Adelman, Z., ... Lamarque, J.-F. F. (2013). Co-benefits of mitigating global greenhouse gas emissions for future air quality and human health. Nature Climate Change, 3(10), 885-889. https://doi.org/10.1038/nclimate2009

Wicaksono, A., Lim, I., Muromachi, Y., Vergel, K. N., Choocharukul, K., Tan, V. H., ... Yai, T. (2015). Roadbased Urban Public Transport and Paratransit in Six Asian Countries: Legal Conditions and Intermodal Issues. Journal of the Eastern Asia Society for Transportation Studies, 11, 227-242.

Wijanarko, Y. (2014). Dishub copot iklan tak berizin di badan angkot. Retrieved February 8, 2017, from http://www.pikiran-rakyat.com/jawa-barat/2014/06/27/287127/dishub-copot-iklan-tak-berizin-dibadan-angkot

Wulandari, C. R. (2015). Pikiran Rakyat. Pikiran Rakyat. Retrieved from http://www.pikiranrakyat.com/bandung-raya/2015

Xia, T., Zhang, Y., \& Crabb, S. (2013). Co-benefits of replacing car trips with alternative transportation: a review if evidence and methodological issues. Environment Public Health, 797312.

Yan. (2015, November 26). Koperasi Angkot Protes, Bus TMB Batal Beroperasi. Juaranews. Com. Retrieved from https://juaranews.com/berita/9326/26/11/2015/koperasi-angkot-protes-bus-tmb-batal- 
beroperasi

Yedla, S., \& Park, H.-S. (2009). Co-benefit as an approach to align climate change concerns with national development objectives: solid waste management. J. Mater Cycles Waste Management, 11, 123-129.

Yin, R. K. (2009). Case Study Research: Design and Methods (4th editio). USA: Sage Publications.

Yusuf, A. A. (2010). Climate Change Issues and Mitigation Actions in Indonesia. In Asia Climate Change Polilcy Forum 2010, Crawford School of Economics and Government. Canberra: the Australian National University.

Zahabi, S. A. ., Miranda-Moreno, L., Patterson, Z., Barla, P., \& Harding, C. (2012). Transportation Greenhouse Gas Emissions and its Relationship with Urban Form, Transit Accessibility and Emerging Green Technologies: A Montreal case study. Social and Behavioral Sciences, 54, 966-978.

Zal, P. (2012). 2012 Daihatsu Gran Max Minibus 1.5D (model for Asia) specifications \& performance data review. Retrieved February 21, 2018, from http://www.automobilecatalog.com/car/2012/1223990/daihatsu_gran_max_mini_bus_1_5_d.html 


\section{Annexure i}

\section{Climate change mitigation in transport sector and selected co-benefits in Bandung City, Indonesia}

\section{QUESTIONNAIRE}

The aim of this research is to advance the understanding and rationalization of climate change mitigation in Bandung City. The researcher will assess the interrelation of climate change mitigation (environmental) policies and transport sector policies in relation to their joint contribution to lowering GHG emissions and meeting selected co-benefits goals. This interview will probably take about 10-15 minutes.

\section{Helmi Gunawan,}

Department of Governance and technology for Sustainability (CSTM), University of Twente, Enschede, the Netherlands

PSDIL Universitas Padjadjaran, Bandung, Indonesia

h.gunawan@utwente.nl

+62816610066

\section{Respondent Identity}

\begin{tabular}{|l|l|}
\hline Name & \\
\hline Institution & \\
\hline Position & \\
\hline Email & \\
\hline Address & \\
\hline Telephone No. & \\
\hline
\end{tabular}

\begin{tabular}{|l|l|l|l|l|l|}
\hline Name of Interviewee & \multicolumn{5}{|c|}{} \\
\hline Interview location & & 2 & 0 & 1 & 6 \\
\hline Date & \multicolumn{5}{|l|}{} \\
\hline Time (a.m / p.m) & \\
\hline Interview duration & \\
\hline
\end{tabular}

\section{Descriptive Phase}

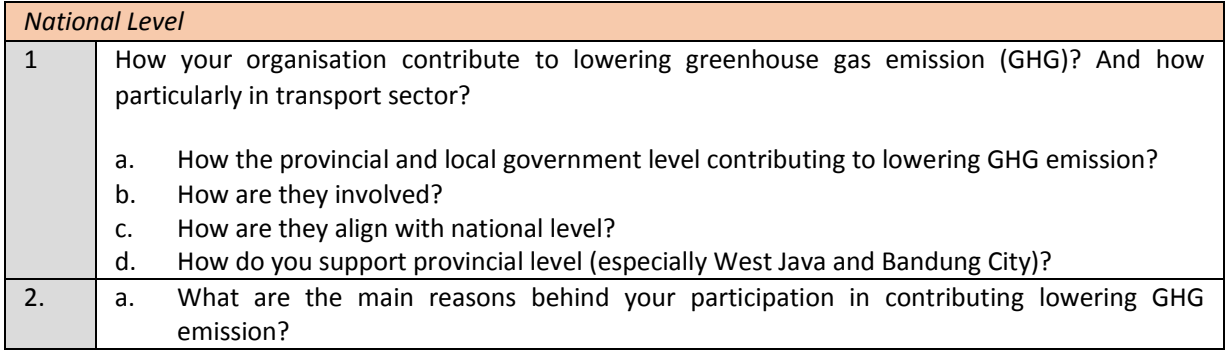




\begin{tabular}{|c|c|c|}
\hline \multicolumn{3}{|c|}{ National Level } \\
\hline & & $\begin{array}{l}\text { Are there any external pressures from others that you have to participate in contributing to } \\
\text { lowering GHG emission? }\end{array}$ \\
\hline 3. & & $\begin{array}{l}\text { would you describe the implementation process of lowering GHG in Indonesia regions after } \\
\text { dential Decree no. } 61 \text { Year } 2011 \text { (National action plan on reducing GHG)? } \\
\text { How particularly in transport sector? What are the best things, what didn't achieve and what } \\
\text { lesson learnt from those experiences? } \\
\text { How this implementation process could benefit others sector? } \\
\text { How this policy instruments being implementation by provincial and local government level? } \\
\text { How does their interpretation in reality? } \\
\text { In your opinion, how information and knowledge do they have to lowering GHG emission } \\
\text { and others co-benefits in simultaneous way? }\end{array}$ \\
\hline 4. & & $\begin{array}{l}\text { What resources do your organisation have to implement the policy instruments (lowering } \\
\text { GHG emission)? (could be capacity and power) } \\
\text { How do these resources influence the interaction process and affect the provincial or local } \\
\text { government level characteristics? } \\
\text { How do your resources could influence relations with other actors (provincial or local) }\end{array}$ \\
\hline 5. & & $\begin{array}{l}\text { Who are the other stakeholders in lowering GHG emission in Indonesia? } \\
\text { Are there any policy / policies that contribute to lowering GHG and also contribute to local } \\
\text { level environment in simultaneously (co-benefits)? }\end{array}$ \\
\hline 6. & & $\begin{array}{l}\text { are the barriers to implement the policy instruments in lowering GHG emission? } \\
\text { o anticipate the barriers? }\end{array}$ \\
\hline 7. & & $\begin{array}{l}\text { dd appreciate if you can give us any useful information (document or files) or informants that } \\
\text { relate to this? }\end{array}$ \\
\hline
\end{tabular}

\begin{tabular}{|c|c|}
\hline \multicolumn{2}{|c|}{ Provincial Level } \\
\hline 1. & $\begin{array}{l}\text { How your organisation contribute to lowering greenhouse gas emission (GHG)? And how } \\
\text { particularly in transport sector? } \\
\text { a. How are they align with national level? } \\
\text { b. How do you support local level (especially Bandung City)? } \\
\text { c. How are they involved? }\end{array}$ \\
\hline 2. & $\begin{array}{l}\text { a. What are the main reasons behind your participation in contributing lowering GHG } \\
\text { emission? } \\
\text { b. Are there any external pressures from others that you have to participate in contributing to } \\
\text { lowering GHG emission? }\end{array}$ \\
\hline 3. & $\begin{array}{l}\text { How would you describe the implementation process of lowering GHG in Indonesia regions after } \\
\text { Presidential Decree no. } 61 \text { Year } 2011 \text { (National action plan on reducing GHG) and how is it align } \\
\text { with Provincial Action Plan on GHG emission reduction? } \\
\text { a. How particularly in transport sector? What are the best things, what didn't achieve and what } \\
\text { b. How this implementation process could benefit others sector? } \\
\text { c. How this policy instruments being implementation by provincial and local government level? } \\
\text { d. How does their interpretation in reality? (Particularly in Bandung City)? } \\
\text { e. In your opinion, how information and knowledge do they have to lowering GHG emission } \\
\text { and others co-benefits in simultaneous way? }\end{array}$ \\
\hline 4. & $\begin{array}{l}\text { a. What resources do your organisation have to implement the policy instruments (lowering } \\
\text { GHG emission)? (Could be capacity and power)? }\end{array}$ \\
\hline
\end{tabular}




\begin{tabular}{|c|c|}
\hline & $\begin{array}{l}\text { b. How do these resources influence the interaction process and affect the provincial or local } \\
\text { government level characteristics? } \\
\text { c. How do your resources could influence relations with other actors (provincial or local)? }\end{array}$ \\
\hline 5. & $\begin{array}{l}\text { a. Who are the other stakeholders in lowering GHG emission? } \\
\text { b. Are there any policy / policies that contribute to lowering GHG and also contribute to local } \\
\text { level environment in simultaneously (co-benefits)? }\end{array}$ \\
\hline 6. & $\begin{array}{l}\text { What are the barriers to implement the policy instruments in lowering GHG emission? } \\
\text { How to anticipate the barriers? }\end{array}$ \\
\hline 7. & $\begin{array}{l}\text { I would appreciate if you can give us any useful information (document or files) or informants that } \\
\text { could relate to this? }\end{array}$ \\
\hline
\end{tabular}

\begin{tabular}{|c|c|}
\hline \multicolumn{2}{|c|}{ Bandung City government } \\
\hline 1. & $\begin{array}{l}\text { How your organisation contribute to lowering greenhouse gas emission (GHG)? And how } \\
\text { particularly in transport sector? } \\
\text { a. How are they aligning with national level and provincial level? } \\
\text { b. How are they involved? }\end{array}$ \\
\hline 2. & $\begin{array}{l}\text { a. What are the main reasons behind your participation in contributing lowering GHG } \\
\text { emission? } \\
\text { b. Are there any external pressures from others that you have to participate in contributing to } \\
\text { lowering GHG emission? }\end{array}$ \\
\hline 3. & $\begin{array}{l}\text { How would you describe the implementation process of lowering GHG in Indonesia regions after } \\
\text { Presidential Decree no. } 61 \text { Year } 2011 \text { (National action plan on reducing GHG)? } \\
\text { a. How is the alignment of Provincial action plan on reducing GHG with your policy instrument } \\
\text { or regional action plan? } \\
\text { b. How particularly in transport sector? What are the best things, what didn't achieve and what } \\
\text { c. How this implementation process could benefit others sector? } \\
\text { d. How this policy instruments being implementation by local government level? } \\
\text { e. How does their interpretation in reality? (particularly Bandung City) } \\
\text { f. In your opinion, how information and knowledge do they have to lowering GHG emission } \\
\text { and others co-benefits in simultaneous way? }\end{array}$ \\
\hline 4. & $\begin{array}{l}\text { a. What resources do your organisation have to implement the policy instruments (lowering } \\
\text { GHG emission)? (could be capacity and power) } \\
\text { b. How do these resources influence the interaction process and affect your organisation? } \\
\text { c. How do your resources could influence relations with other actors (national or provincial) }\end{array}$ \\
\hline 5. & $\begin{array}{l}\text { a. Who are the other stakeholders in lowering GHG emission? } \\
\text { b. Are there any policy / policies that contribute to lowering GHG and also contribute to local } \\
\text { level environment in simultaneously (co-benefits)? }\end{array}$ \\
\hline 6. & $\begin{array}{l}\text { a. What are the barriers to implement the policy instruments in lowering GHG emission? } \\
\text { b. How to anticipate the barriers? }\end{array}$ \\
\hline 7. & $\begin{array}{l}\text { I would appreciate if you can give us any useful information (document or files) or informants that } \\
\text { could relate to this? }\end{array}$ \\
\hline
\end{tabular}

\begin{tabular}{|c|c|c|}
\hline \multicolumn{3}{|c|}{ Target actor } \\
\hline 1. & & $\begin{array}{l}\text { What are the main reasons behind your participation in this policy instruments? } \\
\text { How this policy instrument could contribute to lowering GHG emission? } \\
\text { Is there any expectation that you have to participate in contributing to lowering GHG } \\
\text { emission? }\end{array}$ \\
\hline 2. & a. & How this policy instruments could benefit to others sector? \\
\hline
\end{tabular}




\begin{tabular}{|l|ll|}
\hline \multicolumn{3}{|c|}{ Target actor } \\
\hline & $\begin{array}{l}\text { b. } \\
\text { c. }\end{array} \quad$ How this policy instruments being implemented by provincial and local government level? \\
\hline 3. & a. $\quad \begin{array}{l}\text { How do these policy instruments influence (or empowering) others to lowering GHG } \\
\text { emissions? }\end{array}$ \\
\hline 4. & $\begin{array}{l}\text { a. } \quad \text { How this availability of this policy could access by others? } \\
\text { b. } \quad \begin{array}{l}\text { Is there any policy / policies that contribute to lowering GHG and also contribute to local } \\
\text { level environment in simultaneously (co-benefits)? }\end{array}\end{array}$ \\
\hline 5. & \begin{tabular}{l} 
a. $\quad \begin{array}{l}\text { What are the barriers to implement the policy instruments in lowering GHG emission? } \\
\text { b. How to anticipate the barriers? }\end{array}$ \\
\hline 6.
\end{tabular} & $\begin{array}{l}\text { I would appreciate if you can give us any useful information (document or files) or informants that } \\
\text { could relate to this? }\end{array}$ \\
\hline
\end{tabular}

\section{Interview for evaluative and explanatory (a model of governance of five elements)}

\begin{tabular}{|c|c|}
\hline No & Main question \\
\hline 1 & $\begin{array}{l}\text { Which administrative levels are involved? } \\
\text { How is the interaction between the various administrative levels arranged? } \\
\text { Who decides or influences such issues? } \\
\text { To what extent do they depend on each other or they able act productively on their own? } \\
\text { How is the likelihood in the future? }\end{array}$ \\
\hline 2 & $\begin{array}{l}\text { Which actors are involved in the process? } \\
\text { To what extent do they have network relationships also outside of the case under study? } \\
\text { What are their roles? } \\
\text { Which actors have relevant ownership and use rights (capacity)? } \\
\text { What are the conflicts between these stakeholders? } \\
\text { What form of dialogue between them? } \\
\text { How is the likelihood in the future? }\end{array}$ \\
\hline 3 & $\begin{array}{l}\text { What is seen as a problem and how serious is this considered to be? } \\
\text { What do people see as the causes of the problem? What scale of the problem (individual or } \\
\text { society at large)? Why? } \\
\text { Which policies address this problem? What goals are stipulated in this relevant policy? } \\
\text { How is the likelihood in the future? Why? }\end{array}$ \\
\hline 4 & $\begin{array}{l}\text { Which instruments belong to the policy strategy? } \\
\text { What are the characteristics of these instruments? } \\
\text { What are the target groups of the policy? } \\
\text { How the instrument could measure the policy goals? Why? } \\
\text { How is the likelihood in the future? Why? }\end{array}$ \\
\hline 5 & $\begin{array}{l}\text { Which actors are responsible for implementing the policy? } \\
\text { What authority and other resources are made available to these actors by the policy? } \\
\text { How is the likelihood in the future? Why? }\end{array}$ \\
\hline
\end{tabular}


Main evaluative questions of governance assessment tool (Bressers et al., 2013)

\begin{tabular}{|c|c|c|c|c|}
\hline \multirow{2}{*}{$\begin{array}{l}\text { Governance } \\
\text { dimension }\end{array}$} & \multicolumn{4}{|c|}{ Quality of the governance regime } \\
\hline & Extent & Coherence & Flexibility & Intensity \\
\hline $\begin{array}{l}\text { Levels and } \\
\text { scales }\end{array}$ & $\begin{array}{l}\text { How many levels } \\
\text { are involved and } \\
\text { dealing with an } \\
\text { issue? Are there } \\
\text { any important } \\
\text { gaps or missing } \\
\text { levels? }\end{array}$ & $\begin{array}{l}\text { Do these levels } \\
\text { work together and } \\
\text { do they trust each } \\
\text { other between } \\
\text { levels? To what } \\
\text { degree is the mutual } \\
\text { dependence among } \\
\text { levels recognised? }\end{array}$ & $\begin{array}{l}\text { Is it possible to } \\
\text { move up and } \\
\text { down levels (up } \\
\text { scaling and } \\
\text { downscaling) } \\
\text { given the issue at } \\
\text { stake? }\end{array}$ & $\begin{array}{l}\text { Is there a strong } \\
\text { impact from a } \\
\text { certain level } \\
\text { towards } \\
\text { behavioural } \\
\text { change or } \\
\text { management } \\
\text { reform? }\end{array}$ \\
\hline $\begin{array}{l}\text { Actors and } \\
\text { networks }\end{array}$ & $\begin{array}{l}\text { Are all relevant } \\
\text { stakeholders } \\
\text { involved? Are } \\
\text { there any } \\
\text { stakeholders not } \\
\text { involved or even } \\
\text { excluded? }\end{array}$ & $\begin{array}{l}\text { What is the strength } \\
\text { of interactions } \\
\text { between } \\
\text { stakeholders? In } \\
\text { what ways are these } \\
\text { interactions } \\
\text { institutionalised in } \\
\text { stable structures? } \\
\text { Do the stakeholders } \\
\text { have experience in } \\
\text { working together? } \\
\text { Do they trust and } \\
\text { respect each other? }\end{array}$ & $\begin{array}{l}\text { Is it possible that } \\
\text { new actors are } \\
\text { included or even } \\
\text { that the lead } \\
\text { shifts from one } \\
\text { actor to another } \\
\text { when there are } \\
\text { pragmatic reasons } \\
\text { for this? Do the } \\
\text { actors share in } \\
\text { 'social capital' } \\
\text { allowing them to } \\
\text { sup-port each } \\
\text { other's tasks? }\end{array}$ & $\begin{array}{l}\text { Is there a strong } \\
\text { pressure from an } \\
\text { actor or actor } \\
\text { coalition towards } \\
\text { behavioural } \\
\text { change or } \\
\text { management } \\
\text { reform? }\end{array}$ \\
\hline $\begin{array}{l}\text { Problem } \\
\text { perspectives } \\
\text { and goal } \\
\text { ambitions }\end{array}$ & $\begin{array}{l}\text { To what extent } \\
\text { are the various } \\
\text { problem } \\
\text { perspectives } \\
\text { taken into } \\
\text { account? }\end{array}$ & $\begin{array}{l}\text { To what extent do } \\
\text { the various } \\
\text { perspectives and } \\
\text { goals support each } \\
\text { other, or are they in } \\
\text { competition or } \\
\text { conflict? }\end{array}$ & $\begin{array}{l}\text { Are there } \\
\text { opportunities to } \\
\text { re-assess goals? }\end{array}$ & $\begin{array}{l}\text { How different are } \\
\text { the goal } \\
\text { ambitions from } \\
\text { the status quo or } \\
\text { business as } \\
\text { usual? }\end{array}$ \\
\hline $\begin{array}{l}\text { Strategies and } \\
\text { instruments }\end{array}$ & $\begin{array}{l}\text { What types of } \\
\text { instruments are } \\
\text { included in the } \\
\text { policy strategy? } \\
\text { Are there any } \\
\text { excluded types? } \\
\text { Are monitoring } \\
\text { and enforcement } \\
\text { instruments } \\
\text { included? }\end{array}$ & $\begin{array}{l}\text { To what extent is } \\
\text { the incentive system } \\
\text { based on synergy? } \\
\text { Are trade-offs in } \\
\text { cost benefits and } \\
\text { distributional } \\
\text { effects considered? } \\
\text { Are there any } \\
\text { overlaps or conflicts } \\
\text { of incentives } \\
\text { created by the } \\
\text { included policy } \\
\text { instruments? }\end{array}$ & $\begin{array}{l}\text { Are there } \\
\text { opportunities to } \\
\text { combine or make } \\
\text { use of different } \\
\text { types of } \\
\text { instruments? Is } \\
\text { there a choice? }\end{array}$ & $\begin{array}{l}\text { What is the } \\
\text { implied } \\
\text { behavioural } \\
\text { deviation from } \\
\text { current practice } \\
\text { and how strongly } \\
\text { do the } \\
\text { instruments } \\
\text { require and } \\
\text { enforce this? }\end{array}$ \\
\hline
\end{tabular}




\begin{tabular}{|c|c|c|c|c|}
\hline \multirow{2}{*}{$\begin{array}{l}\text { Governance } \\
\text { dimension }\end{array}$} & \multicolumn{4}{|c|}{ Quality of the governance regime } \\
\hline & Extent & Coherence & Flexibility & Intensity \\
\hline $\begin{array}{l}\text { Responsibilities } \\
\text { and re-sources }\end{array}$ & $\begin{array}{l}\text { Are all } \\
\text { responsibilities } \\
\text { clearly assigned } \\
\text { and facilitated } \\
\text { with resources? }\end{array}$ & $\begin{array}{l}\text { To what extent do } \\
\text { the assigned } \\
\text { responsibilities } \\
\text { create competence } \\
\text { struggles or } \\
\text { cooperation within } \\
\text { or across } \\
\text { institutions? Are } \\
\text { they considered } \\
\text { legitimate by the } \\
\text { main stakeholders? }\end{array}$ & $\begin{array}{l}\text { To what extent is } \\
\text { it possible to pool } \\
\text { the assigned } \\
\text { responsibilities } \\
\text { and resources as } \\
\text { long as } \\
\text { accountability and } \\
\text { transparency are } \\
\text { not } \\
\text { compromised? }\end{array}$ & $\begin{array}{l}\text { Is the amount of } \\
\text { allocated } \\
\text { resources } \\
\text { sufficient to } \\
\text { implement the } \\
\text { measures needed } \\
\text { for the intended } \\
\text { change? }\end{array}$ \\
\hline
\end{tabular}

\section{Guidelines of interview}

\section{a. Descriptive questions}

National level and Provincial

\begin{tabular}{|l|l|}
\hline Questions & Description \\
\hline 1 & Structural context (general) \\
\hline 2. & Motivation \\
\hline 3. & Cognition \\
\hline 4. & Resources \\
\hline 5. & Specific context \\
\hline 6. & Wider context \\
\hline
\end{tabular}

Target actors

\begin{tabular}{|l|l|}
\hline Questions & Description \\
\hline 1 & Motivation \\
\hline 2. & Cognition \\
\hline 3. & Resources \\
\hline 4. & Specific context \\
\hline 5. & Wider context and problem perceptions \\
\hline
\end{tabular}

b. Evaluative and explanatory questions

\begin{tabular}{|l|l|}
\hline Questions & Description \\
\hline 1 & Levels and scales of governance \\
\hline 2 & Actors and policy network \\
\hline 3 & Problems perception and policy objectives \\
\hline 4 & Strategies and instruments \\
\hline 5 & Responsibilities and resources for implementation \\
\hline
\end{tabular}

Bandung City government

\begin{tabular}{|l|l|}
\hline Questions & Description \\
\hline 1 & Structural context \\
\hline 2. & Motivation \\
\hline 3. & Cognition \\
\hline 4. & Resources \\
\hline 5. & Specific context \\
\hline 6. & Wider context and problem perceptions \\
\hline
\end{tabular}




\section{Annexure ii}

\section{RESEARCH SURVEY OF WILLINGNESS TO CHANGE IN TRANSPORT SECTOR}

The aim of this research is to advance the understanding and rationalisation of climate change mitigation in transport sector in Bandung City. We need your opinion about travel attitudes and preference of public transport mode, car and motorcycle as well as the climate change mitigation and congestion. It is assured that your information will remain confidential. This survey will probably take about 10-15 minutes

Part I: Please report your personal information as listed below. Write in.... or mark $\boldsymbol{V}$ inside $\square$ for your best option

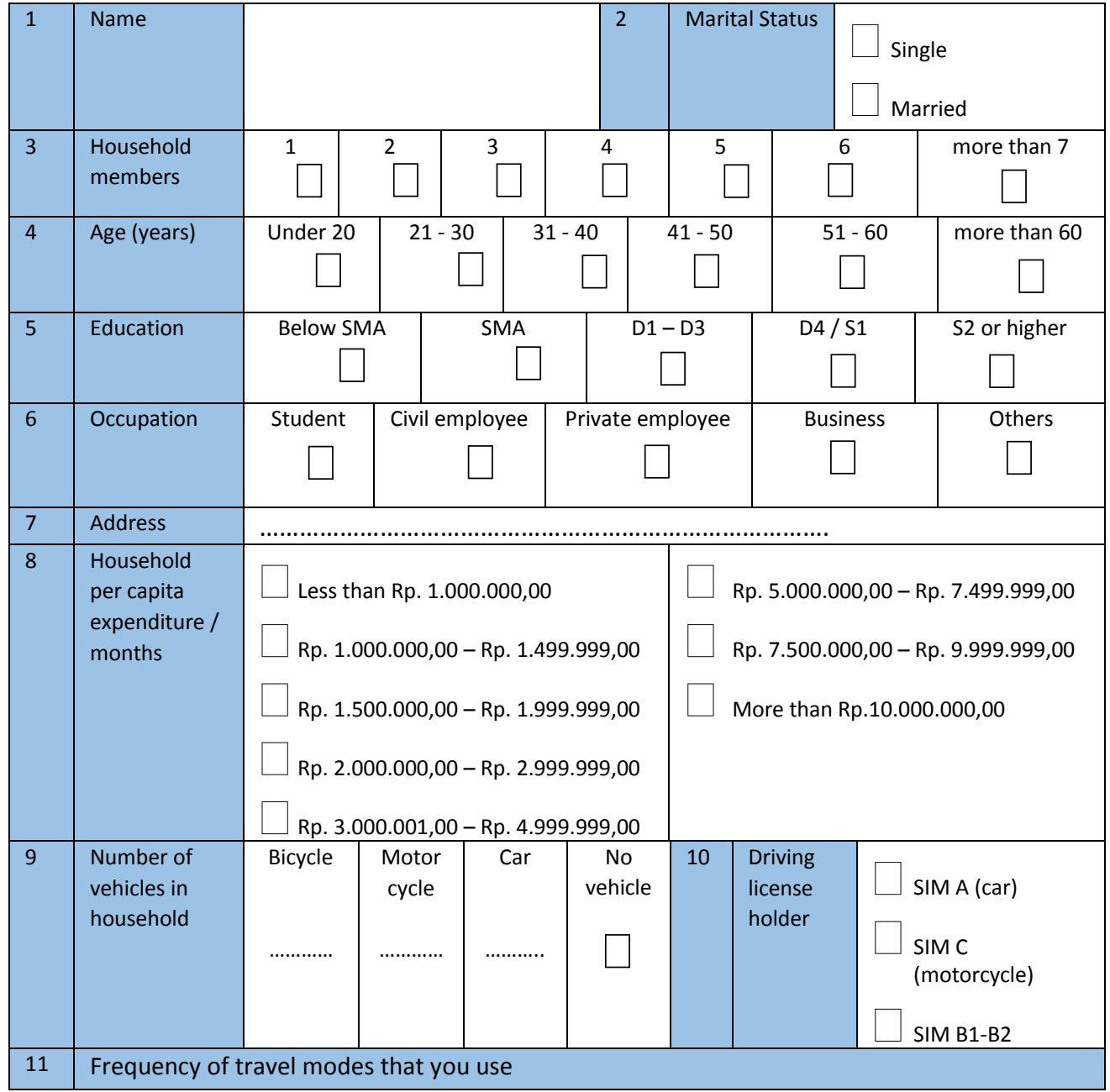




\begin{tabular}{|c|c|c|c|c|c|c|c|c|}
\hline & Travel modes & $\begin{array}{c}\text { Once a } \\
\text { day }\end{array}$ & $\begin{array}{l}\text { More } \\
\text { than } \\
\text { once a } \\
\text { day }\end{array}$ & $\begin{array}{c}\text { Less than } \\
\text { once a } \\
\text { day }\end{array}$ & $\begin{array}{c}\text { Once or } \\
\text { twice a } \\
\text { week }\end{array}$ & $\begin{array}{c}\text { Less } \\
\text { than } \\
\text { once a } \\
\text { week }\end{array}$ & $\begin{array}{l}\text { Less } \\
\text { than } \\
\text { once a } \\
\text { month }\end{array}$ & Never \\
\hline A & Car (driver or passenger) & & & & & & & \\
\hline$B$ & $\begin{array}{l}\text { Motorcycle (driver/ } \\
\text { passenger) }\end{array}$ & & & & & & & \\
\hline C & Paratransit (angkot) & & & & & & & \\
\hline $\mathrm{D}$ & Bus (Damri / TMB) & & & & & & & \\
\hline $\mathrm{E}$ & Ride a bike & & & & & & & \\
\hline $\mathrm{F}$ & Uber/ Gojek & & & & & & & \\
\hline
\end{tabular}

Part II. Please show your level of agreement with each statement.

\begin{tabular}{|c|c|c|c|c|c|c|}
\hline \multicolumn{2}{|c|}{$\begin{array}{l}\text { In answering all questions please checklist } \sqrt{ } \\
\text { your best option. }\end{array}$} & \multirow[t]{2}{*}{$\begin{array}{l}\text { Strongly } \\
\text { agree }\end{array}$} & \multirow[t]{2}{*}{$\begin{array}{l}\text { Tend to } \\
\text { agree }\end{array}$} & \multirow[t]{2}{*}{ Neutral } & \multirow[t]{2}{*}{$\begin{array}{l}\text { Tend to } \\
\text { disagree }\end{array}$} & \multirow[t]{2}{*}{$\begin{array}{l}\text { Strongly } \\
\text { Disagree }\end{array}$} \\
\hline 12 & $\begin{array}{l}\text { The global climate change is not the } \\
\text { main problem to deal with (P1) }\end{array}$ & & & & & \\
\hline 13 & $\begin{array}{l}\text { The congestion is al local problem } \\
\text { that one should deal with (P2) }\end{array}$ & & & & & \\
\hline 14 & $\begin{array}{l}\text { The transport sector is a source of } \\
\text { climate change in the urban area (P3) }\end{array}$ & & & & & \\
\hline 15 & $\begin{array}{l}\text { The public transport is a tool to } \\
\text { reduce climate change (P4) }\end{array}$ & & & & & \\
\hline 16 & $\begin{array}{l}\text { I am willing to use low emission } \\
\text { public transport to reduce air } \\
\text { pollution (P5) }\end{array}$ & & & & & \\
\hline 17 & $\begin{array}{l}\text { I am willing to use private vehicles, } \\
\text { even if the public transport offers the } \\
\text { shorter time (P6) }\end{array}$ & & & & & \\
\hline 18 & $\begin{array}{l}\text { I prefer to use public transport even if } \\
\text { must walk longer (more than } 400 \\
\text { meters) (P7) }\end{array}$ & & & & & \\
\hline 19 & $\begin{array}{l}\text { It is not possible to use public } \\
\text { transport if there is a lot of travel } \\
\text { destination (P8) }\end{array}$ & & & & & \\
\hline 20 & $\begin{array}{l}\text { The tax that I paid for developing the } \\
\text { public transport to reduce an air } \\
\text { pollution (P9) }\end{array}$ & & & & & \\
\hline 21 & $\begin{array}{l}\text { The government needs to increase } \\
\text { the parking fee to reduce the use of } \\
\text { private vehicles and encourage the } \\
\text { use of public transport (P10) }\end{array}$ & & & & & \\
\hline
\end{tabular}




\begin{tabular}{|l|l|l|l|l|l|l|}
\hline 22 & $\begin{array}{l}\text { The government needs to increase } \\
\text { the price of gasoline to reduce the } \\
\text { use of private transport (P11) }\end{array}$ & & & & & \\
\hline 23 & $\begin{array}{l}\text { Paratransit (angkot) helps as a } \\
\text { solution to reduce the climate change } \\
\text { (P12) }\end{array}$ & & & & & \\
\hline 24 & $\begin{array}{l}\text { Bus (TMB) helps as a solution to } \\
\text { reduce the climate change (P13) }\end{array}$ & & & & & \\
\hline
\end{tabular}

\begin{tabular}{|c|c|}
\hline Part III & $\begin{array}{l}\text { Please rank the following order from } 1 \text { to } 7 \text { where } 1 \text { is most important to you and } 7 \text { is less } \\
\text { important. }\end{array}$ \\
\hline 25 & $\begin{array}{l}\text { I am travelling by car or motorcycle from home to work or study because of ... } \\
\square \text { safe and comfort } \\
\square \text { fast } \\
\square \text { lack of direct public transport } \\
\square \text { need for multiple journey } \\
\square \text { cheaper } \\
\square \text { cleanliness } \\
\square \text { prestige (high social value) }\end{array}$ \\
\hline 26 & $\begin{array}{l}\text { I will be traveling by public transport IF } \\
\square \text { safe and comfort } \\
\square \text { cleanliness } \\
\square \text { cheaper } \\
\square \text { hard to have a private vehicle (car or motorcycle) } \\
\square \text { contribute to a better environment } \\
\square \text { reduction of traffic congestion } \\
\square \text { fast }\end{array}$ \\
\hline 27 & $\begin{array}{l}\text { Source of congestion: } \\
\begin{array}{l}\square \text { Private cars } \\
\square \text { Motorcycle }\end{array}\end{array}$ \\
\hline
\end{tabular}




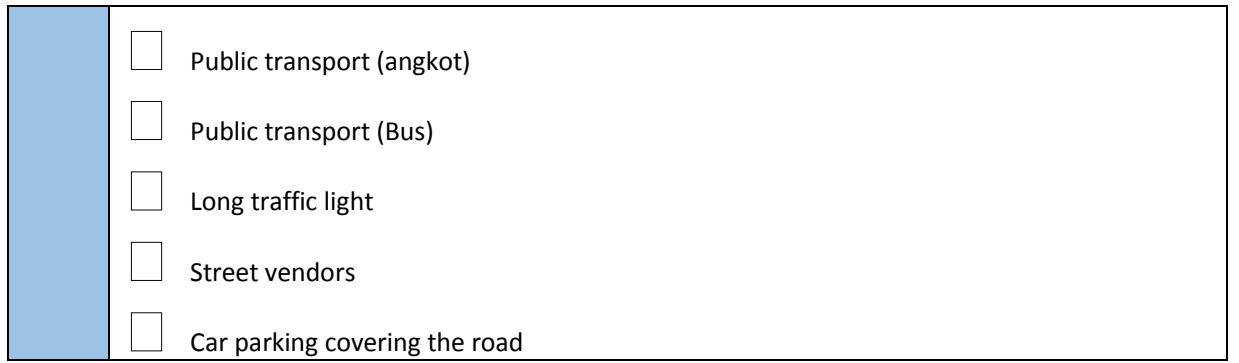

Guidelines of Questionnaire of Willingness to Change adapted from Environmental Significant Behaviour by Stern (2000)

\begin{tabular}{|c|c|c|}
\hline Independent & Parameter & $\begin{array}{c}\text { Indicator number in } \\
\text { questionnaire }\end{array}$ \\
\hline \multicolumn{3}{|l|}{ Attitudinal } \\
\hline $\begin{array}{l}\text { General } \\
\text { environmentalist } \\
\text { predisposition (attitudes } \\
\text { to change) }\end{array}$ & $\begin{array}{l}\text { Attitude in climate change } \\
\text { Perceived source of congestion }\end{array}$ & $\begin{array}{l}\text { Number } 12 \\
\text { Number } 13\end{array}$ \\
\hline $\begin{array}{l}\text { Behaviour-specific } \\
\text { norms and beliefs } \\
\text { (Awareness of } \\
\text { consequences) }\end{array}$ & $\begin{array}{l}\text { Personal norm of using } \\
\text { transportation } \\
\text { The consequences of using public } \\
\text { transport }\end{array}$ & $\begin{array}{l}\text { Number } 14 \\
\text { Number } 15\end{array}$ \\
\hline 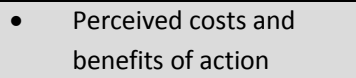 & $\begin{array}{l}\text { Perceived traveling by personal } \\
\text { vehicles and public transport }\end{array}$ & Number $16,17,18,19$ \\
\hline \multicolumn{3}{|l|}{ Personal Capabilities } \\
\hline - $\quad$ Social status and power & Use personal vehicle & Number 9, 11 \\
\hline - $\quad$ Financial resources & $\begin{array}{l}\text { Income (expenditure), personal } \\
\text { vehicle, license holder }\end{array}$ & Number $8,9,10$ \\
\hline \multicolumn{3}{|l|}{ Contextual Factors } \\
\hline - Law and regulations & $\begin{array}{l}\text { Increasing the parking fees or fuel } \\
\text { charges for use car less, restrict the } \\
\text { use of motorised transportation for } \\
\text { better environment }\end{array}$ & Number 20, 21, 22 \\
\hline - $\quad$ Supportive policies & $\begin{array}{l}\text { Support for government policy } \\
\text { option }\end{array}$ & Number 23, 24 \\
\hline \multicolumn{3}{|l|}{ Habit and routine } \\
\hline $\begin{array}{l}\text { - Frequency of travel } \\
\text { modes use }\end{array}$ & & Number 11 \\
\hline
\end{tabular}




\section{SUMMARY}

Climate policy has a strong influence on policy processes at the national level in Indonesia. Meanwhile, other policies that focus on air quality improvement are also being implemented at local levels. Indonesia has committed to reducing greenhouse gas (GHG) emissions by 29 percent by 2030 . This calls into question the extent to which cities and local governments can cope with the challenges of the current transport sector climate change mitigation programmes. Bandung City is one example. The main objective of this study is to contribute to the understanding of the role of a multiplicity of actor characteristics and contextual factors in the transport sector climate change mitigation policies and governance in Bandung City.

The main research question is: - how do actor characteristics, interaction between actors and contextual factors influence the implementation of climate change mitigation in the transport sectors and contribute to selected co-benefits? And based on this: - how can climate change mitigation policies in the transport sector be improved? The research design employed an empirical case study on governance and policy relevant to climate change efforts to lower GHG emissions in Bandung City. The study evaluated the climate change mitigation programmes and the air quality improvements using the actor-based framework of the Contextual Interaction Theory (CIT). The governance and stakeholder characteristics of climate change mitigation were also analysed with the structural context part of the CIT framework using the Governance Assessment Tool (GAT). A survey of actor's willingness to use different modes of transport and travel behaviour enriched the policy evaluation.

The results show that air quality improvement policy has been implemented separately from climate policy. The former operates at the local level and the latter at the national level. The actor interaction analysis concluded that a more holistic environmental policy approach would be more efficient in reducing local air pollution and contributing to the mitigation of climate change. It is also confirmed that the policies to reduce GHG emission do not accord with government edicts. The provincial and local government were aware that the central government stipulation for mitigation on climate change provides for regulation at both provincial and local levels. However, most actors at these levels lacked information about implementation. This study found that actors have considered and chosen mitigation programmes given the limits of their knowledge, resources, and power. Several policies encouraging reduced GHG emissions require a multi-actor interaction process. Local actors and the provincial level in Bandung City proposed the Paratransit and Car-Free Day programmes to help reduce transport GHG emission. Other programmes, such as the Trans Metro Bandung (TMB) and vehicle emissions tests, were also expected to reduce GHG emissions.

The results of the quality of governance assessment showed that all programmes are supporting climate change mitigation as stipulated by government. The extent to which this was the case was found to be low to moderate; flexibility as restrictive, and coherence and intensity as moderate. In general, these qualities created a context with some limits. However, several improvements and positive trends were apparent at the local level. The governance assessment of the climate change mitigation programmes as perceived by the actors concluded that problems of differing actor perspectives and goals were faced by all cases, which often complicated the development of the operational programmes. 
The assessment of co-benefit criteria for three policy instruments found this approach was most relevant to public transport, given the actual condition of the programmes. The TMB as a bus rapid transit met all the criteria of co-benefits. Thus, this programme has had the highest impact in delivering co-benefits. The private sector paratransit system had positive value for the criteria of lowering GHG emissions, energy and environmental sustainability, and achieving development goals. The vehicle emission test met the criteria of sustainability and technical feasibility.

However, the three programmes that encouraged the use of public transport often ran contrary to other actor's needs (in this case, private vehicle users). The survey of willingness to use alternative transport modes found a positive correlation between the travel mode choice of vehicle users and their perception on how to lower GHG emissions. A negative correlation existed between vehicle users with their perception of GHG emission issues and policies to mitigate climate change. Other positive findings were found between the socio-economic characteristics with travel behaviour and environmentally significant behaviour. The intention to use a particular mode of transport was, to a large degree, dependent on a vehicle's ownership. Car users correlated more positively with this issue than motorcycle owners. The frequency of use of one particular transport mode encouraged this use to become habitual and this determined their willingness to reduce the use of private vehicles or increase the use of public transport. As a result, we believe that the policy to encourage the use of public transport will be hindered by the existing use of private vehicles. In the absence of any policy intervention to reduce private vehicles, the programme to raise awareness, and encourage people to use public transport, will experience many obstacles.

Three factors were found to be important for travel mode use, namely: speed, safety, and comfort. Secondary contributory factors affecting public transportation use were low-prices and difficulties faced to own and use private vehicles. The intention to use private vehicles was strongly related to user's needs to access multiple destinations. Knowledge and information, people's awareness regarding environmental impact, global environmental issues, and the use of public transport, would not be the indicators to reduce the environmental impact of the private cars.

The policy scenarios represented in this survey covered: increasing taxes, increasing parking prices, and fuel increment as key variables of travel behaviour. However, all respondents accepted that fuel increment would intervene and reduce the use of private vehicles. The results showed that any increase in gasoline prices could encourage use of public vehicles. This policy could reduce gasoline consumption. It would create a national economic benefit by reducing subsidies to society and benefit the environment.

The study concludes that, based on the dynamic actors-interaction framework, climate change policies, especially mitigation in the transportation sector in the city of Bandung, several programmes can reduce GHG emissions. However, governance aspects remain limited, although some programmes have improved. These programmes will be unable to succeed in helping to reduce GHG emissions if the behaviour of actors, especially private vehicle users, are not well managed. 


\section{SUMMARY (in Bahasa)}

Kebijakan iklim memiliki pengaruh yang kuat terhadap proses kebijakan di tingkat nasional di Indonesia. Sementara kebijakan lainnya dengan fokus pada peningkatan kualitas udara juga dilaksanakan di tingkat lokal. Indonesia telah berkomitmen untuk mengurangi emisi gas rumah kaca (GRK) sebesar 29 persen pada tahun 2030. Menjadi sebuah pertanyaan sejauh mana kotakota dan pemerintah daerah dapat mengatasi tantangan mitigasi perubahan iklim di sektor transportasi saat ini. Kota Bandung sebagai contoh kasus. Tujuan utama penelitian adalah berkontribusi untuk memahami peran dari keragaman karakteristik-karakteristik aktor dan faktor-faktor kontekstual dari kebijakan mitigasi perubahan iklim di sektor transportasi dan tata kelolanya di Kota Bandung.

Pertanyaan penelitian adalah bagaimana karakteristik-karakteristik aktor, interaksi antar aktoraktor serta faktor-faktor kontekstual mempengaruhi implementasi dari mitigasi perubahan iklim di sektor transportasi serta berkontribusi terhadap manfaat tambahan? dan berdasarkan hal tersebut bagaimana kebijakan perubahan iklim di sektor transportasi dapat ditingkatkan? Desain penelitian melibatkan studi kasus empiris tentang tata kelola dan kebijakan yang relevan dengan upaya perubahan iklim untuk menurunkan GRK di Kota Bandung. Studi mengevaluasi program mitigasi perubahan iklim dan peningkatan kualitas udara menggunakan kerangka kerja berbasisaktor dari Contextual Interaction Theory (CIT). Tata kelola dan karakteristik pemangku kepentingan dari mitigasi perubahan iklim juga dianalisis menggunakan konteks struktural yang merupakan bagian dari kerangka kerja CIT yaitu dengan menggunakan Governance Assessment Tool (GAT). Survei kesediaan pengguna kendaraan untuk menggunakan mode transportasi dan perilaku perjalanan memperkaya analisis evaluasi kebijakan yang dilakukan.

Hasil penelitian menunjukkan bahwa kebijakan peningkatan kualitas udara lebih banyak diimplementasikan terpisah dari kebijakan iklim. Kebijakan peningkatan kualitas udara dilakukan di tingkat lokal dan kebijakan iklim beroperasi di tingkat pusat. Berdasarkan analisis interaksi antar-aktor, disimpulkan bahwa pendekatan kebijakan lingkungan yang holistik akan lebih efisien dalam mengurangi polusi udara di tingkat lokal dan berkontribusi pada mitigasi perubahan iklim. Penting untuk diperhatikan bahwa kebijakan dalam mengurangi emisi gas rumah kaca tidak sesuai dengan apa yang ditetapkan oleh pemerintah. Pemerintah provinsi dan Pemerintah kabupaten dan kota menyadari bahwa ketentuan yang disampaikan oleh pemerintah pusat mengenai mitigasi perubahan iklim tercantum dalam peraturan baik di tingkat provinsi dan lokal. Namun, sebagian besar aktor di tingkat provinsi dan lokal tidak memiliki informasi terkait implementasi di tingkat lokal. Studi ini menemukan bahwa para aktor telah mempertimbangkan bahwa program mitigasi dipilih berdasarkan aspek pengetahuan, sumber daya, dan kekuatan yang ada. Secara umum, kebijakan yang mendorong pengurangan emisi gas rumah kaca merupakan proses interaksi multi-aktor. Angkutan Kota dan Car-Free Day diusulkan oleh aktor di tingkat daerah berpengaruh dalam mengurangi emisi gas rumah kaca di sektor transportasi. Program lain seperti Trans Metro Bandung dan uji emisi kendaraan dirasakan oleh para aktor dapat mengurangi emisi gas rumah kaca. 
Hasil penelitian memperlihatkan kualitas tata kelola menunjukkan bahwa semua program yang mendukung mitigasi perubahan iklim sesuai ketentuan pemerintah. Bahwa aspek jangkauan (extent) berada dalam tingkat rendah menuju sedang, fleksibilitas dari program sangat terbatas serta koherensi dan intensitas pada tingkat moderat. Secara umum, hasil ini mengindikasikan berdasarkan tatakelola masih terdapat beberapa hambatan. Meskipun beberapa perbaikan dan trend positif telah terlihat di tingkat lokal. Penilaian tata kelola program mitigasi perubahan iklim yang dirasakan dari semua kasus, yang menyulitkan pengembangan program yang sedang berjalan.

Dari penilaian kriteria co-benefits untuk ketiga instrumen kebijakan, pendekatan ini lebih relevan bagi transportasi umum, penilaian ini diasumsikan sesuai dengan kondisi sebenarnya. TMB sebagai bus rapid transit telah memenuhi semua kriteria co-benefits. Dengan demikian, program TMB ini memiliki dampak tertinggi untuk mencapai co-benefits. Paratransit memiliki nilai positif dari kriteria menurunkan emisi gas rumah kaca, manfaat reduksi energi dan kelestarian lingkungan, serta tujuan pembangunan. Tes emisi kendaraan memenuhi kriteria keberlanjutan dan kelayakan teknis.

Namun tiga program yang mendorong penggunaan angkutan umum telah ditanggapi sebaliknya oleh aktor lain (dalam kasus ini terkait pengguna kendaraan pribadi). Survey terkait keinginan menggunakan berbagai alternatif mode transportasi ditemukan korelasi positif antara pilihan menggunakan pengguna kendaraan dengan persepsinya untuk mengurangi emisi GRK. Korelasi negatif terjadi antara pengguna kendaraan dengan persepsinya terhadap isu emisi GRK dan kebijakan-kebijakan terkait mitigasi perubahan iklim. Temuan positif lainnya adalah antara karakteristik sosial ekonomi dengan perilaku perjalanan dan perilaku ramah lingkungan. Keinginan untuk menggunakan moda transportasi sebagian besar lebih bergantung pada kepemilikan kendaraan. Pengguna mobil lebih berkorelasi positif dengan hal ini daripada pemilik sepeda motor. Frekuensi penggunaan moda transportasi mendorong pengguna kendaraan menjadi kebiasaan dan hal ini ditentukan dari keinginan untuk mengurangi penggunaan kendaraan pribadi atau meningkatkan penggunaan transportasi umum. Sebagai hasilnya, peneliti percaya bahwa kebijakan untuk mendorong penggunaan transportasi umum akan terhambat oleh pengguna kendaraan pribadi yang telah ada sebelumnya. Dengan tidak adanya intervensi kebijakan untuk mengurangi kendaraan pribadi, program untuk meningkatkan kesadaran dan mendorong masyarakat menggunakan angkutan umum hal ini akan menemui banyak kendala.

Terdapat tiga faktor yang penting untuk dipertimbangkan dalam menggunakan mode perjalanan, yaitu cepat, aman, dan nyaman. Kontributor kedua yang mempengaruhi penggunaan transportasi umum adalah faktor ongkos yang rendah dan sulitnya memiliki kendaraan pribadi. Keinginan untuk menggunakan kendaraan pribadi lebih mendorong kebutuhan responden karena memiliki beberapa tujuan perjalanan. Pengetahuan dan informasi, kesadaran mengenai dampak lingkungan, masalah lingkungan global, dan penggunaan transportasi umum tidak menjadi indikator untuk mengurangi dampak lingkungan dari penggunaan mobil pribadi. 
Skenario kebijakan yang dalam survei ini diwakili oleh peningkatan pajak, peningkatan ongkos parkir, dan kenaikan harga bahan bakar menjadi variabel perilaku perjalanan. Namun semua responden menerima bahwa kenaikan bahan bakar dapat mengintervensi dan mengurangi penggunaan kendaraan pribadi. Hasilnya menunjukkan bahwa kenaikan harga bensin dapat mendorong responden untuk menggunakan transportasi umum. Kebijakan ini diharapkan dapat mengurangi konsumsi bensin. Hal tersebut dapat menciptakan manfaat bagi ekonomi nasional kepada masyarakat dan bermanfaat bagi lingkungan.

Kesimpulan akhir dari studi ini memperlihatkan bahwa berdasarkan kerangka interaksi antaraktor yang dinamis yang berada dalam kebijakan perubahan iklim, khususnya mitigasi di sektor transportasi di Kota Bandung menunjukkan bahwa beberapa program dapat menurunkan emisi GRK. Namun demikian aspek tata kelolanya masih terbatas walaupun beberapa program telah terdapat perbaikan. Program-program tersebut akan sulit untuk berhasil membantu mengurangi emisi GRK bila aspek-aspek perilaku para aktor terutama pengguna kendaraan pribadi masih tidak dapat dikelola dengan baik. 


\section{Samenvatting (Summary in Dutch)}

Klimaatbeleid heeft een sterke invloed op beleidsprocessen op nationaal niveau in Indonesië. Ondertussen worden ook andere beleidsmaatregelen die gericht zijn op verbetering van de luchtkwaliteit geïmplementeerd op lokaal niveau. Indonesië heeft toegezegd de uitstoot van broeikasgassen (BKG) in 2030 met 29 procent te verminderen. Dit roept vragen op over de mate waarin steden en lokale overheden de uitdagingen van de huidige klimaatveranderingsprogramma's voor klimaatverandering aankunnen. Bandung City is daar een voorbeeld van. Het hoofddoel van deze studie is bij te dragen aan het begrijpen van de rol van allerlei actorkenmerken en contextuele factoren in de transportsector, bij het klimaatmitigatiebeleid en het bestuur in Bandung City.

De belangrijkste onderzoeksvraag is: - hoe beïnvloeden actorkenmerken, interactie tussen actoren en contextuele factoren de implementatie van de beperking van klimaatverandering door de transportsector en dragen ze bij aan geselecteerde co-benefits? En op basis hiervan: hoe kan het mitigatiebeleid voor klimaatverandering in de transportsector worden verbeterd? Het onderzoeksontwerp maakte gebruik van een empirische case study over bestuur en beleidsmaatregelen die relevant zijn voor de inspanningen om de uitstoot van broeikasgassen in Bandung City te verminderen. De studie evalueerde de mitigatieprogramma's voor klimaatverandering en de verbetering van de luchtkwaliteit met behulp van het op actoren gebaseerde raamwerk van de contextuele interactie-theorie (CIT). De governance- en stakeholderkenmerken van de mitigatie van klimaatverandering werden ook geanalyseerd met behulp van het onderdeel "structurele context" van het CIT-raamwerk met behulp van de Governance Assessment Tool (GAT). Een onderzoek naar de bereidheid van actoren om verschillende vervoerswijzen en reisgedrag te gaan gebruiken, verrijkte de beleidsevaluatie.

Uit de resultaten blijkt dat het beleid voor verbetering van de luchtkwaliteit los van het klimaatbeleid is geïmplementeerd. Het eerste opereert op lokaal niveau en het tweede op nationaal niveau. De analyse van de interactie van de actoren concludeerde dat een meer holistische benadering van het milieubeleid meer efficiënt zou zijn in het verminderen van lokale luchtverontreiniging en het bijdragen aan de matiging van de klimaatverandering. Ook wordt bevestigd dat het beleid ter beperking van de uitstoot van broeikasgassen niet strookt met de voorschriften van de overheid. De provinciale en lokale overheid waren zich ervan bewust dat de eis van de centrale overheid voor mitigatie van klimaatverandering voorziet in regulering op zowel provinciaal als lokaal niveau. De meeste actoren op deze niveaus misten echter informatie over de implementatie. Uit deze studie bleek dat actoren mitigatieprogramma's hebben overwogen en gekozen, binnen de grenzen van hun kennis, middelen en macht. Verschillende beleidsmaatregelen ter beperking van de uitstoot van broeikasgassen vereisen een interactieproces met meerdere actoren. Lokale actoren en het provinciale niveau in Bandung City stelden de programma's Paratransit en Autovrije dag voor om de broeikasgasemissies te verminderen. Andere programma's, zoals de Trans Metro Bandung (TMB) en voertuigemissietests, zouden naar verwachting ook de uitstoot van broeikasgassen verminderen. 
De resultaten van de beoordeling van de kwaliteit van de governance context hebben aangetoond dat alle programma's de mitigering van de klimaatverandering ondersteunen zoals bepaald door de overheid. De reikwijdte (compleetheid) waarin dit het geval was, bleek laag tot matig te zijn; de geringe mate van flexibiliteit was beperkend, en de samenhang en intensiteit warden beoordeeld als matig. Over het algemeen creëerden deze kwaliteiten een context met een aantal beperkingen. Er waren echter verschillende verbeteringen en positieve trends op lokaal niveau. De beoordeling van de governance van de programma's voor de beperking van de klimaatverandering, zoals waargenomen door de actoren, concludeerde dat in alle gevallen het hoofd moest worden geboden aan uiteenlopende probleemperspectieven en doelstellingen van de verschillende actoren, wat de ontwikkeling van de operationele programma's vaak bemoeilijkte.

Uit de beoordeling van de mate van potentiële co-benefits van drie beleidsinstrumenten bleek dat deze aanpak het meest relevant was voor het openbaar vervoer, gezien de actuele toestand van de programma's. De TMB als snelle busreis voldeed aan alle criteria van co-benefits. Dit programma heeft dus de grootste impact gehad op het leveren van aanvullende voordelen. Het paratransit-systeem van de particuliere sector had een positieve waarde voor de criteria om de uitstoot van broeikasgassen, energie en milieuduurzaamheid te verlagen en ontwikkelingsdoelen te bereiken. De voertuigemissietest voldeed aan de criteria van duurzaamheid en technische haalbaarheid.

De drie programma's die het gebruik van het openbaar vervoer aanmoedigden, waren echter vaak in strijd met de behoeften van andere actoren (in dit geval gebruikers van privé-voertuigen). Het onderzoek naar de bereidheid om alternatieve vervoerswijzen te gebruiken, vond een positieve correlatie tussen de keuze van de reismodus van voertuiggebruikers en hun perceptie van het belang van het verlagen van de uitstoot van broeikasgassen. Er was een negatieve correlatie bij voertuiggebruikers met hun perceptie van broeikasgasemissies en het beleid om de klimaatverandering te matigen. Andere positieve bevindingen werden gevonden tussen bepaalde sociaal-economische kenmerken met reisgedrag en ecologisch significant gedrag. De intentie om een bepaald vervoermiddel te gebruiken, was in grote mate afhankelijk van het eigendom van een voertuig. Autogebruikers correleerden sterker in dit opzicht dan motorbezitters. De frequentie van het gebruik van een bepaalde transportmodus stimuleerde dit gebruik om gewoon te worden en dit bepaalde hun bereidheid om het gebruik van privévoertuigen te verminderen of het gebruik van het openbaar vervoer te vergroten. Daarom zijn wij van mening dat het beleid om het gebruik van het openbaar vervoer aan te moedigen, wordt belemmerd door het bestaande gebruik van privévoertuigen. Bij gebrek aan enige beleidsinterventie om het gebruik van privé-voertuigen te verminderen, zal het programma om het bewustzijn te vergroten en mensen aan te moedigen om het openbaar vervoer te gebruiken, veel obstakels ervaren.

Drie factoren bleken belangrijk te zijn voor gebruik in de reismodus, namelijk: snelheid, veiligheid en comfort. Secundaire bijdragende factoren die van invloed zijn op het gebruik van het openbaar vervoer waren lage prijzen en moeilijkheden om particuliere voertuigen te bezitten en te 
gebruiken. De intentie om privévoertuigen te gebruiken was sterk gerelateerd aan de behoeften van gebruikers om toegang te krijgen tot meerdere bestemmingen. Kennis en informatie, het bewustzijn van mensen met betrekking tot milieueffecten, wereldwijde milieukwesties en het gebruik van openbaar vervoer, zijn niet de indicatoren om de milieu-impact van de personenauto's te verminderen.

De beleidsscenario's die in deze enquête zijn weergegeven, hadden betrekking op: het verhogen van de belastingen, het verhogen van de parkeertarieven en het verhogen van de brandstof als belangrijkste variabelen voor het reisgedrag. Alle respondenten erkenden echter dat de toename van brandstofprijzen invloed zou hebben en het gebruik van privévoertuigen zou verminderen. De resultaten toonden aan dat elke stijging van de benzineprijzen het gebruik van openbare vervoer zou kunnen stimuleren. Dit beleid kan het benzineverbruik verminderen. Het zou een nationaal economisch voordeel opleveren door de subsidies aan de samenleving te verminderen en het zou het milieu ten goede te komen.

De studie concludeert, op basis van de dynamische actoren-interactie analyse, dat binnen het klimaatveranderingsbeleid, met name mitigatie in de transportsector in de stad Bandung, verschillende programma's de uitstoot van broeikasgassen kunnen verminderen. De kwaliteit van de aspecten van de governance context blijft echter beperkend, hoewel sommige programma's zijn verbeterd. Deze programma's zullen er niet in slagen om bij te dragen aan het terugdringen van de uitstoot van broeikasgassen als het gedrag van actoren, met name gebruikers van privévoertuigen, niet goed wordt gemanaged. 


\begin{abstract}
About the Author
Helmi was born in March 1974 as a second child of Lin Karlina and Burhaeni in Bandung City, which hosts the fourth largest population in Indonesia. Almost all levels of education of the author were completed in Bandung City. In 1986, the author finished his elementary school for special education teacher school (SDN Latihan SGPLB). The author finished his junior high school at SMPN 2 Bandung in 1989. He continued to study at the senior high school (SMAN 5 Bandung) and had finished by 1992. The author holds a Bachelor Degree of Environmental Engineering in 1997 from ITB. He also graduated from ITB and holds a Master of Science degree obtained in 2007. He received full funding from a Ministry of Education and Cultural scholarship. In 2012, the author registered as a double doctoral degree student from Universitas Padjadjaran and University of Twente, the Netherlands; also, with a scholarship from the Ministry of Education and Cultural (BU-BPKLN) and funding from the Government of West Java Province. Since 2010, the author has worked at the West Java Environmental Protection Agency.
\end{abstract}

